SUPPLEMENTAL TECHNICAL DATA SUMMARY

M-AREA GROUNDWATER INVESTIGATION

I. WENDELL MARINE

HORACE W. BLEDSOE

Approved by:

J. C. Corey, Research Manager Environmental Sciences Division

Status as of: October 1984

Publication Date: October 1985

E. I. du Pont de Nemours \& Co. Savannah River Laboratory Aiken, SC. 29808 PREPARED FOR THE U.S. DEPARTMENT OF ENERGY UNDER CONTRACT DE-ACO9-76SR00001 


\section{DISCLAIMER}

Portions of this document may be illegible in electronic image products. Images are produced from the best available original document. 


\section{DISCLAIMER}

This report was prepared as an account of work sponsored by an agency of the United States Government. Neither the United States Government nor any agency thereof, nor any of their employees, makes any warranty, express or implied, or assumes any legal liability or responsibility for the accuracy, completeness, or usefulness of any information, apparatus, product, or process disclosed, or represents that its use would not infringe privately owned rights. Reference herein to any specific commercial product, process, or service by trade name, trademark, manufacturer, or otherwise does not necessarily constitute or imply its endorsement, recommendation, or favoring by the United States Government or any agency thereof. The views and opinions of authors expressed herein do not necessarily state or reflect those of the United States Government or any agency thereof. 


\begin{tabular}{|c|c|c|c|}
\hline & \multirow{2}{*}{$\frac{\text { Page }}{1-1}$} \\
\hline 1.0 & \multicolumn{2}{|c|}{ INTRODUCTION AND ACKNOWLEDGEMENTS } & \\
\hline 2.0 & \multicolumn{2}{|c|}{ SUMMARY } & $2-1$ \\
\hline 3.0 & \multicolumn{2}{|c|}{ GEOHYDROLOGIC SETTING } & $3-1$ \\
\hline & \multicolumn{2}{|c|}{ References for Chapter 3} & $3-3$ \\
\hline 4.0 & \multicolumn{2}{|c|}{ MONITORING WELL INSTALLATION } & $4-1$ \\
\hline 5.0 & \multicolumn{2}{|c|}{ GEOHYDROLOGY } & $5-1$ \\
\hline & \multirow[t]{3}{*}{$\begin{array}{l}5.1 \\
5.2\end{array}$} & $\begin{array}{l}\text { Geology } \\
\text { Subsurface Hydrology }\end{array}$ & $\begin{array}{l}5-1 \\
5-2\end{array}$ \\
\hline & & $\begin{array}{ll}5.2 .1 & \text { Recharge } \\
5.2 .2 & \text { Potentiometric Maps and Groundwater } \\
\text { Velocity }\end{array}$ & $5-2$ \\
\hline & & $\begin{array}{l}\text { 5.2.3 Water-Level Fluctuations } \\
5.2 .4 \text { Groundwater Discharge }\end{array}$ & $5-7$ \\
\hline & \multirow[t]{2}{*}{5.3} & Hydraulic Properties & $5-7$ \\
\hline & & $\begin{array}{l}\text { 5.3.1 Laboratory Tests - } \\
5.3 .2 \text { Recovery Tests on Observation Wells } \\
5.3 .3 \text { Water Injection Test on Well MPT-1 } \\
5.3 .4 \text { 30-Day. Pumping Test in Tertiary Sediments } \\
5.3 .5 \text { "Tuscaloosa" Aquifer Pumping Test }\end{array}$ & $\begin{array}{l}5-7 \\
5-8 \\
5-8 \\
5-9 \\
5-11\end{array}$ \\
\hline & \multicolumn{2}{|c|}{ References for Chapter 5} & $5-13$ \\
\hline 6.0 & \multicolumn{2}{|c|}{ POTENTIAL SOURCES OF DEGREASER SOLVENTS } & $6-1$ \\
\hline & $\begin{array}{l}6.1 \\
6.2\end{array}$ & $\begin{array}{l}\text { Introduction } \\
\text { History and Locations of Potential Degreaser } \\
\text { Solvent Releases }\end{array}$ & $6-1$ \\
\hline & & $\begin{array}{l}\text { Magnitude of Degreaser Solvent Releases } \\
\text { Sources of Substances Other Than Degreaser } \\
\text { Solvents }\end{array}$ & $6-5$ \\
\hline & \multicolumn{2}{|c|}{ References for Chapter 6} & $6-8$ \\
\hline
\end{tabular}


Contents, Contd

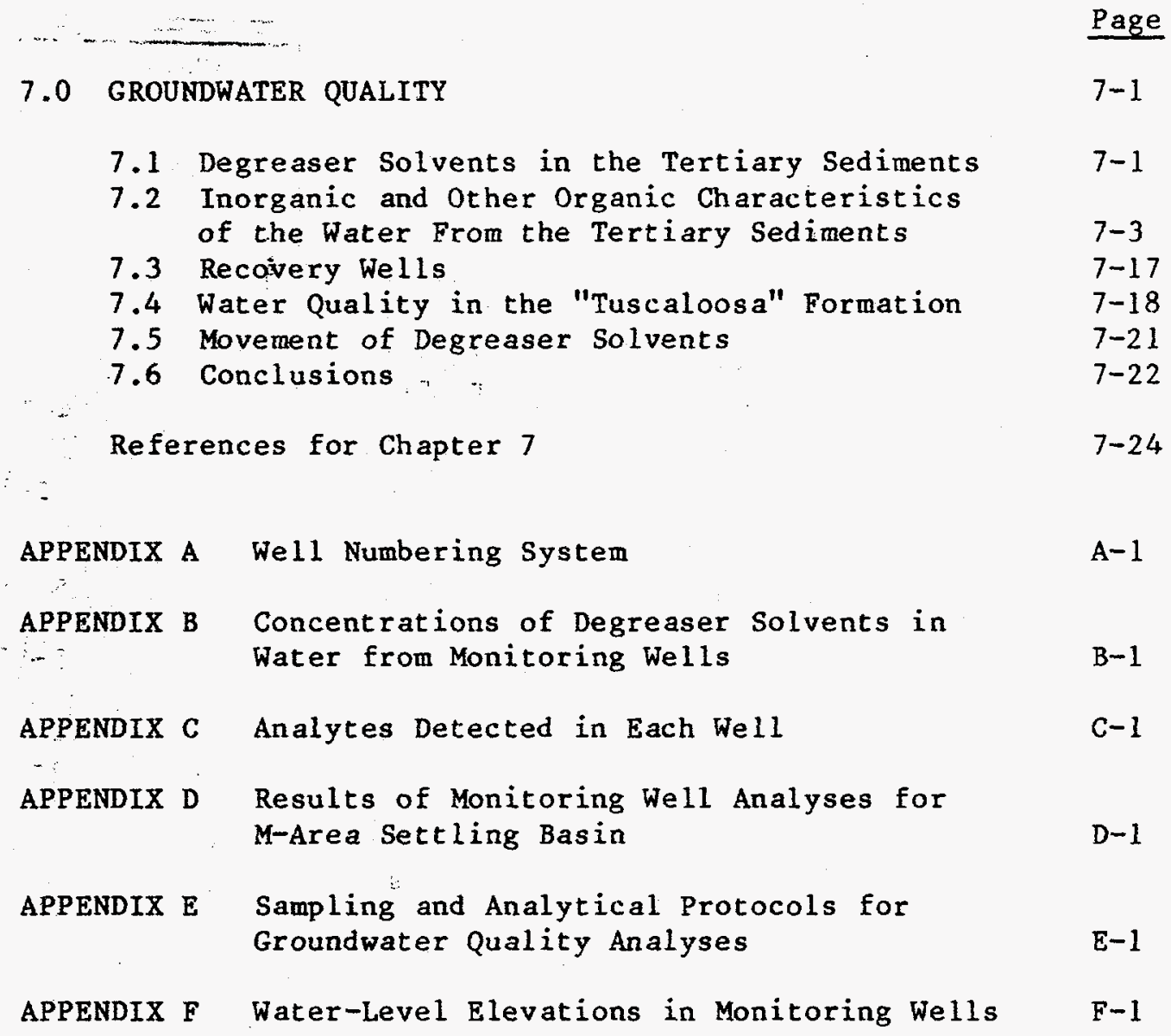


4-1 History of Investigations of Groundwater Contamination in $\mathrm{A} / \mathrm{M}$ Area

$4-3$

4-2 M-Area Piezometer Installation Summary

4-3 Piezometer Installation Data Summary for Wells From Other Programs Used to Collect Information for M-Area Investigations

$4-7$

5-1 Summary of Soil Test Results "5-15

5-2 Results of Recovery Tests on Individual

Observation Wells in M Area

5-3 Injection Profile for MPT-1 5-17

5-4 Results from the Step-Drawdown Test on Production Well 905-20A Screened in the "Tuscaloosa" Formation 5-17

5-5 Summary of Hydraulic Properties of the "Tuscaloosa" Aquifer as Determined From a Pumping Test on Production Well 905-20A

6-1 Estimated Quantity of Degreaser Solvent Released to M-Area Process Sewers

7-1 Estimate of Inventory of Degreaser Solvents in the Saturated Zone

7-2 Elements, Compounds, and Properties for Which Analyses Were Made on Samples of Water Collected From Monitoring Wells

7-3 Wells Where Leaching of Cement may be Influencing the Concentration of Analytes

7-4 Analyses of Degreaser Solvents, $\mathrm{pH}$, Temperature, and Conductivity During 30-Day Pumping Test on MPT-1

7-5 Analyses of Inorganic Chemistry of Selected Water Samples from MPT-1 During 30-Day Pumping Test

7-6 Results of Soil Analyses for Degreaser Solvents in the Ellenton Formation at Monitor We11 MSB-23A 
3-1 Tentative Correlation of Stratigraphic Terminology of the Southwestern South Carolina Coastal Plain 3-4

3-2 Geology and Hydrology Near the Center of $A / M$ Area 3-5.

3-3: Generalized Head Difference Between the "Tuscaloosa" and Congaree Formations at SRP 3-6

3-4 Hydrologic Section Perpendicular to the Savannah River Through M Area

4-1 Location of Existing Wells Used for Groundwater Monitoring

4-2 Location of Production and Monitoring Wells Screened in the "Tuscaloosa" Formation Near M Area and Production Wells Screened in the Tertiary Sediments

4-3 Location of Proposed Monitoring Well Clusters 4-10

5-1 Geologic Section Emphasizing the Ellenton and "Tuscaloosa" Formations from MSB 34 to MSB 12

5-2 Location of Water Disposal Areas

5-3 Water Table Elevation Map for Spring 1984

5-4 Potentiometric Map of the Elevation Interval where the Top of Screen is Between 146 and $187 \mathrm{ft}$, i.e., 50 Below the "Green Clay", for April-June 1984

5-5 Potentiometric Map of the Elevation Interval where the Top of Screen is Between 100 and $144 \mathrm{ft}$, i.e., in Basal Tertiary Sediments, for April-June 1984

5-6 Potentiometric Map of the Elevation Interval where the Top of the Screen is Between 14 and $76 \mathrm{ft}$, i.e., Upper "Tuscaloosa" Formation, for May 1984

5-7 Water Levels at Selected Depths at MSB-12 5-25

5-8 Water Levels at Selected Depths at MSB-34 5-26

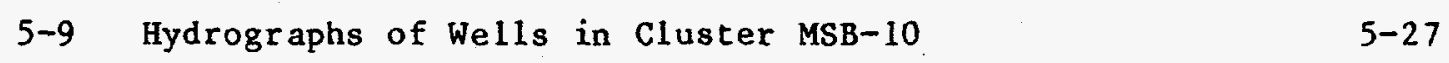

5-10 Hydrographs of Wells in Cluster MSB-11 5-28 


\section{LIST OF FIGURES, Contd}

\begin{tabular}{|c|c|c|}
\hline $5-11$ & Hydrographs of Wells in Cluster MSB-12 & $5-29$ \\
\hline $5-12$ & Hydrographs of Wells in Cluster MSB-17 & $5-30$ \\
\hline $5-13$ & Hydrographs of Wells in Cluster MSB- 34 & $5-31$ \\
\hline $5-14$ & Hydrograph of Well s-15 & $5-32$ \\
\hline $5-15$ & $\begin{array}{l}\text { Schematic Section of Screen Zones and Water Levels } \\
\text { of MSB-11 Well Cluster and Production Test We } 11\end{array}$ & $.5-33$ \\
\hline $5-16$ & Results of Water Injection Test on MPT-1 & $5-34$ \\
\hline $5-17$ & $\begin{array}{l}\text { Comparison of Drawdowns in MPT-1 for 3-Day and } \\
\text { 30-Day Pumping Tests }\end{array}$ & $5-35$ \\
\hline $5-18$ & $\begin{array}{l}\text { Water Levels in Observation Wells MSB-11B } \\
\text { and } 11 \mathrm{C} \text { During } 30-\text { Day Pumping Test }\end{array}$ & $5-36$ \\
\hline $5-19$ & $\begin{array}{l}\text { Log-Log Plot of Drawdown for Observation Well } \\
\text { MSB-11C During 30-Day Pumping Test }\end{array}$ & $5-37$ \\
\hline $5-20$ & $\begin{array}{l}\text { Location of Wells Utilized in the "Tuscaloosa" } \\
\text { Pumping Test }\end{array}$ & $5-38$ \\
\hline $5-21$ & $\begin{array}{l}\text { Hydrograph of Well 905-20A During "Tuscaloosa" } \\
\text { Pumping Test }\end{array}$ & $5-39$ \\
\hline $5-22$ & $\begin{array}{l}\text { Hydrographs of Observation Wells MSB-30A and } \\
\text { MSB-23A Screened in the "Tuscaloosa" }\end{array}$ & $5-40$ \\
\hline $5-23$ & $\begin{array}{l}\text { Hydrographs of Observation Wells MSB- } 23 \text { and } \\
\text { MSB-23B Screened in Tertiary Sediments }\end{array}$ & $5-41$ \\
\hline $6-1$ & Locations of Potential or Suspected Contaminant Releases & $6-10$ \\
\hline $6-2$ & $\begin{array}{l}\text { Degreaser Solvents Used as Metal Degreasers at } \\
\text { M-Area Facilities }\end{array}$ & $6-11$ \\
\hline $6-3$ & $\begin{array}{l}\text { Estimated Annual Discharge of Degreaser } \\
\text { Solvents to the Process Sewers }\end{array}$ & $6-12$ \\
\hline $7-1$ & $\begin{array}{l}\text { Concentration Profiles of Total Degreaser Solvents } \\
\text { from Soil and Water Samples at Well Cluster MSB-23 }\end{array}$ & $7-32$ \\
\hline $7-2$ & $\begin{array}{l}\text { Results of Soil and Water Analyses for Degreaser } \\
\text { Solvents at Site MSB- } 24\end{array}$ & $7-33$ \\
\hline
\end{tabular}


LIST OF FIGURES, Contd

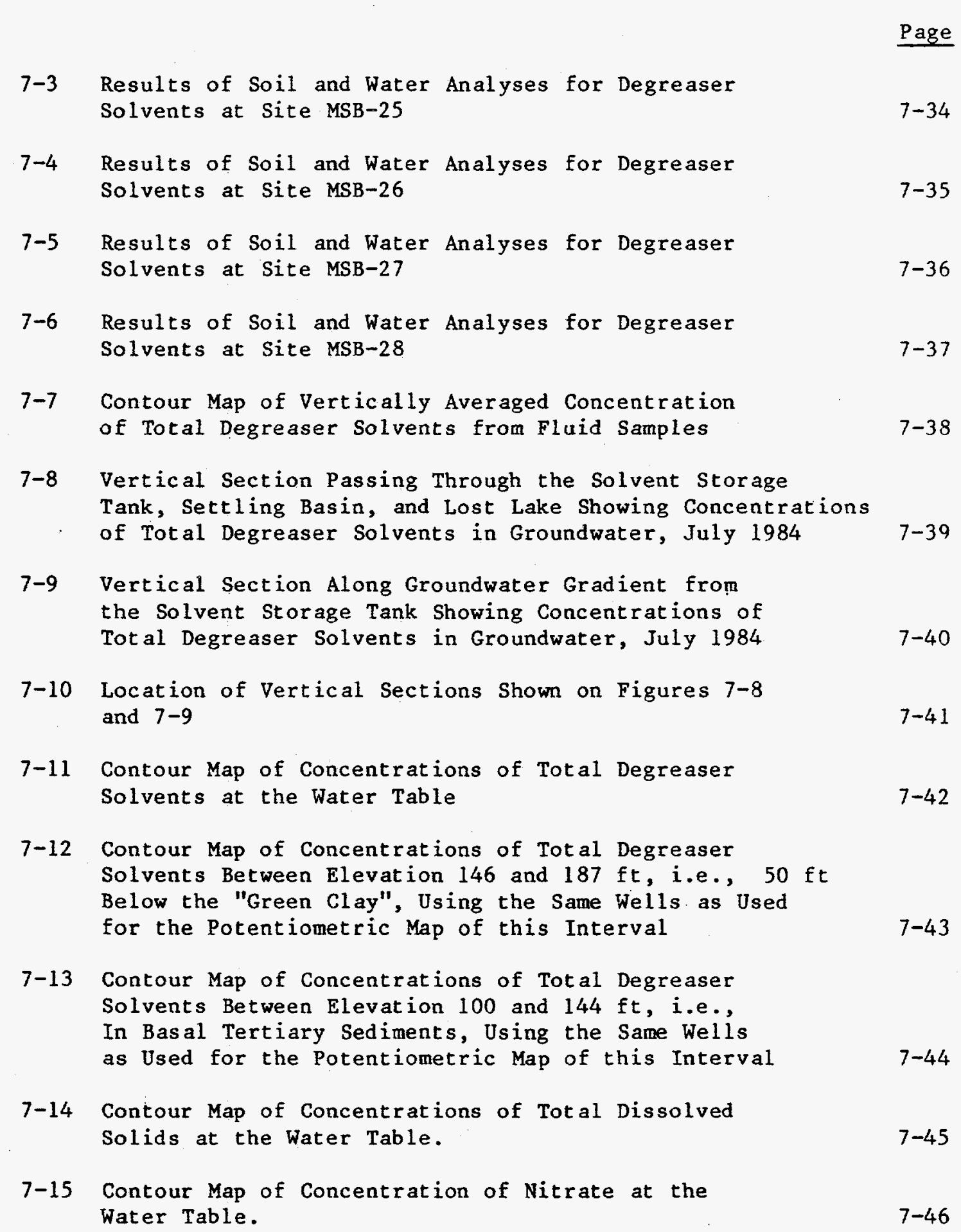


LIST OF FIGURES, Contd

Page

7-16 Graph of Concentration of Degreaser Solvents vs. Time at Well MPT-1

$7-47$

7-17 Location of Pilot, Demonstration, and Recovery Wells for Removal of Degreaser Solvents from Groundwater

7-18 Graph of Concentration of Degreaser Solvents vs. Time at We 11 RWM-2

7-19 Graph of Concentration of Degreaser Solvents vs. Time at Well RWM-3

7-20 Graph of Time/Concentration for Trichloroethylene Plus Tetrachloroethylene in Water from Wells in Cluster MSB-9

7-21 Graph of Time/Concentration for Trichloroethylene Plus Tetrachloroethylene in Water from Wells in Cluster MSB-14

7-22 Graph of Time/Concentration for Trichloroethylene Plus Tetrachloroethylene in Water from Wells in Cluster MSB-19

7-23 Graph of Time/Concentration for Trichloroethylene Plus Tetrachloroethylene in Water from Well MSB-26A

7-24 Graph of Time/Concentration for Trichloroethylene Plus Tetrachloroethylene in Water from Well MSB-28A 
- $\mathrm{x}-$ 
A Preliminary Technical Data Summary, M-Area Groundwater Cleanup Facility (Gordon, 1982), was issued in October 1982. The objective of the Preliminary Technical Data Summary (TDS) was to present data that would lead to selection and design of a groundwater cleanup facility as a remedial action for the contamination by volatile degreaser solvents of the groundwater south and west of the M-Area settling basin on the Savannah River Plant (SRP). Since that time additional monitoring wells have been drilled and other sources of contamination have been identified. In addition, the use of recovery wells and an air stripper, which were the remedial measures recommended in the preliminary TDS, have been selected as the best suited clean-up technology. A project to implement these remedial measures is under way. Start-up of a 400 gallon per minute air stripping column with an eleven well recovery network is expected in April 1985. (Editorial Note: The air stripping column began operation in April 1985, and all eleven recovery wells were on line by September 1985.)

Because of the additional investigations and results that have developed in the intervening two years (October 1982 to October 1984), it is appropriate to compile the results of these investigations and issue a supplement to the Preliminary Technical Dat a Summary. Since investigations of the overall contaminant plume in $A$ and $M$ Areas are continuing, this report is not a final report but only an update of the technical data on this complex situation.

Because the previous TDS covered the topic of treatment of the groundwater once brought to the surface, this supplemental data summary does not address treatment technology at the surface. Primarily, it provides additional geohydrologic and contaminant plume information.

The organization and presentation of the chemical analyses in Appendices $B$ and $C$ and the water level elevations in Appendix $F$ are primarily the work of William Fay, an independant contractor to the Savannah River Laboratory (SRL). John Pickett (SRL) contributed to the interpretation of the results of the inorganic chemical analyses. William Colven and Carl Muska of the Raw Materials Engineering and Technology Department at SRP are the custodians of most of the wells from which data were used in this study and were largely responsible for the collection of much of the data. H. Lee Martin of Raw Materials Technology gathered much of the history of M-Area operations. The groundwater consulting firm of Geraghty \& Miller, Inc. conducted and analysed the pumping test on the "Tuscaloosa" aquifer. Envirodyne Engineers, Inc. performed most of the chemical analyses that appear in Appendices B, C, and D. 
References for Chapter 1

Gordon, D. E., 1982. Preliminary Technical Data Summary, M-Area Groundwater Cleanup Pacility, DPSTD 82-69, E. I. du Pont de Nemours and Co., Savannah River Laboratory, Aiken, SC. 
This supplement to the Preliminary Technical Data Summary (TDS) (Gordon, 1982) presents the state of knowledge on the hydrogeology and contaminant plume characteristics in the vicinity of $M$ Area as of October 1984. As discussed in the previous TDS, the contaminants consist of organic solvents used for metal degreasing, namely trichloroethylene, tetrachloroethylene, and 1,1,1-trichloroethane. Since the issuance of the previous TDS, the groundwater consulting firm of Geraghty \& Miller, Inc. has been retained to assist with program strategy, planning, and investigative techniques.

The investigation to October 1984 indicates that there are four main areas or sources of groundwater contamination: 1) the M-Area settling basin, 2) the pipeline extending from the production facilities to the basin, 3) the above ground solvent storage tanks behind Building $321-M$, and 4 ) the sewer outfall to a tributary to Tims Branch.

The major extent of chlorocarbon contamination is primarily contained within the formations of Tertiary age (i.e. Barnwell, McBean, and Congaree) which overlie the regionally important "Tuscaloosa" Formation. The water bearing Tertiary and "Tuscaloosa" Formations are separated by 40 to 60 feet of clays and sandy clays of the Ellenton and Upper "Tuscaloosa" Formations. Several of the water production wells screened in the "Tuscaloosa" Formation have shown low levels of contamination; however, it is believed that this has resulted from a loss of integrity of the cement sheath surrounding the casing and not from a pervasive movement of the contamination into the "Tuscaloosa" Formation. (Editorial Note: Data gathered after October 1984 indicates that there may be other sources for individual wells than faulty cement grout.)

The shape, extent, and concentration of the plume to the west and southwest of the basin and the M-Area production facilities have been fairly well determined using currently available data. At the present time however, the characteristics of the plume to the north, east, and along Tims Branch and its tributary that has received process effluent is based on data from a small number of monitoring wells.

A remedial action program consisting of a series of 11 recovery wells and a 400-gpm air stripping unit is currently being implemented for cleaning up the contaminated groundwater system. 


\section{References for Chapter 2}

Gordon, D. E., 1982. Preliminary Technical Data Summary, M-Area Groundwater Cleanup Facility, DPSTD-82-69, E. I. du Pont de Nemours and Co., Savannah River Laboratory, Aiken, SC. 


\subsection{GEOHYDROLOGIC SETTING}

The geohydrologic setting of the Savannah River Plant (SRP) is described in "Technical Summary of Groundwater Quality Protection Program at Savannah River Plant," (Christensen and Gordon, 1983). Figure 3-1 presents a tentative correlation of stratigraphic terminology and shows a descriptive and graphic log of the subsurface geology near the central part of SRP. The hydrostratigraphic terms used in the present report are those shown on Figure 3-1 except that the term "Tuscaloosa" requires further clarification.

The Tuscaloosa Formation was named by Smith and Johnson (1887, p.98) for exposures of light-colored irregularly bedded non-marine sediments near Tuscaloosa, Alabama. Subsequently, the name was applied to strata thought to be equivalent in Georgia by Spencer (1890) and in South Carolina by Cooke.(1936, p. 17), who correlated the Hamburg and Middendorf beds of Sloan (1908) with the Tuscaloosa of Georgia. When the original geologic studies were performed for the building of the Savannah River Plant, Cooke's terminology was used in its entirety. Subsequently, siple (1967) also used the term Tuscaloosa although he cites other studies that indicate sediments at Middendorf (Chesterfield County), which had been included in the Tuscaloosa, were younger than the age of the Tuscaloosa beds in Alabama. In hydrologic work at SRP the term Tuscaloosa, referring to the principal aquifer in the region, has been quite useful, and its meaning is quite clear. In recent years analysis of pollen found in this formation at SRP have established that it is indeed younger than the Tuscaloosa type section in Alabama. Thus, from a purely stratigraphic point of view, it is improper to continue to use the term Tuscaloosa for these sediments. However, historical usage of the term in a hydrostratigraphic sense is clear, and it would seem that its use should not be hastily changed. As intensive stratigraphic studies in this area are now going on, it is probable that the use of the term Tuscaloosa to designate this large aquifer (which actually consists of two aquifers separated by a confining bed) will be discontinued. However, in this report the term Tuscaloosa Formation will be retained but placed within quotation marks to indicate that it is used as a hydrostratigraphic term and not as a formal stratigraphic term.

Because $M$ Area is updip from the central part of SRP, several changes in the geologic column are present. Figure 3-2 shows a generalized geologic colum in $M$ Area. In comparing the stratigraphic column in $M$ Area with that of the central part of the 
plant, it should be noted that (1) the "Tan $\mathrm{Clay"}$ is only about 3 feet thick and lies in the unsaturated zone, (2) the "Calcareous Zone" is not present, ( 3 ) the "Green Clay" is discontinuous, (4) the Congaree has fewer separated lenses of clay and lenses of sand and is better described generally as clayey sand even though well-sorted sands do occur, (5) the Ellenton Formation is mostly a gray clayey sand or sandy clay with plentiful mica and the occurrence of marcasite or gypsum, and (6) the "Tuscaloosa" section is similar to that described for the central part of SRP.

As a result of these different geologic features, the subsurface hydrologic characteristics also differ. Since the extensive layers of clay are absent from the Tertiary sediments, head changes are less abrupt and are more gradual than in the central part of SRP. The water table is deeper below the surface. The "Green Clay" is less continuous and therefore does not impede downward water flow as much as in the central part of SRP. Because the Congaree has fewer permeable sands and lateral conduction of water within the Congaree Formation is slower than in the central part of the plant, the head in the Congaree'is not drawn down below that of the "Tuscaloosa." Therefore, in A/M Area, heads decline continuously with depth, and there is no head reversal at the CongareeEllenton boundary (Figure 3-3). (Figure 3-3 was developed in early 1983 by subtracting contours on a Congaree potentiometric map from those on a "Tuscaloosa" potentiometric map. Data for both of these original potentiometric maps were very sparse. Thus, Figure 3-3 is intended to show the general concept of head reversal and the general area involved. However, it should not be used for quantitative prediction of head reversal at any specific location.)

However, there is sufficient hydraulic impedance in the section such that lateral groundwater flow at the water table may move in one direction and lateral flow in the deeper Tertiary sediments may move in a slightly different direction responding to hydraulic controls from Tims Branch and from Upper Three Runs Creek. Figure 3-4 presents a regional section through $M$ Area to Shell Bluff, Georgia showing the head relationship of the Congaree and the "Tuscaloosa." Although the "Tuscaloosa" head is below that of the Congaree in the vicinity of M Area, as the Savannah River is approached the two potentiometric surfaces cross and the Tuscaloosa becomes the higher of the two. The same relationship would pertain in the direction of Upper Three Runs Creek.

One of the most important hydrologic features of A/M Area is the declining head with depth (Figure 3-2), meaning that water soluble material released at the surface will tend to move to greater depth in the general area. This situation changes as the Savannah River or Upper Three Runs Creek are approached. 
References for Chapter 3

Christensen, E. J. and D. E. Gordon, 1983. Technical Summary of Groundwater Quality Protection Program at Savannah River Plant, Vol. 1 DPST-83-829, E. I. Du Pont de Nemours and Co., Savannah River Laboratory, Aiken, SC.

Cooke, C. W., 1936. Geology of the Coastal Plain of South Carolina, U.S. Geological Survey Bulletin 867.

Huddleston, P., 1982. The Development of the Stratigraphic Terminology of the Claibornian and Jacksonian Marine Deposits in Western South Carolina and Eastern Georgia, Geological Investigations Related to the Stratigraphy in the Raolin Mining District, Aiken County, South Carolina - Carolina Geological Society Pield Trip Guidebook, pp. 211-33.

Mittwede, S. K., 1982. Stratigraphy of the Jackson Area, Aiken County, South Carolina, Geological Investigations Related to the Stratigraphy in the Raolin Mining District, Aiken County, South Carolina - Carolina Geological Society Field Trip Guidebook, pp. 65-78.

Siple, G. E., 1967. Geology and Ground Water of the Savannah River Plant and Vicinity, South Carolina, U.S. Geological Survey Water-Supply Paper 1841.

Sloan, Earle, 1908. Catalogue of the Mineral Localities of South Carolina, South Carolina Geological Survey Bulletin 2 Series 4.

Smith, E. A. and L. C. Johnson, 1887. Tertiary and Cretaceous Strata of the Tuscaloosa, Tombigbee, and Alabama Rivers, U.S. Geological Survey Bulletin 43.

Spencer, J. W. W., 1890. "Southern Drift" and its Agricultural Relation, Agricultural Experiment Station Bulletin 6. 


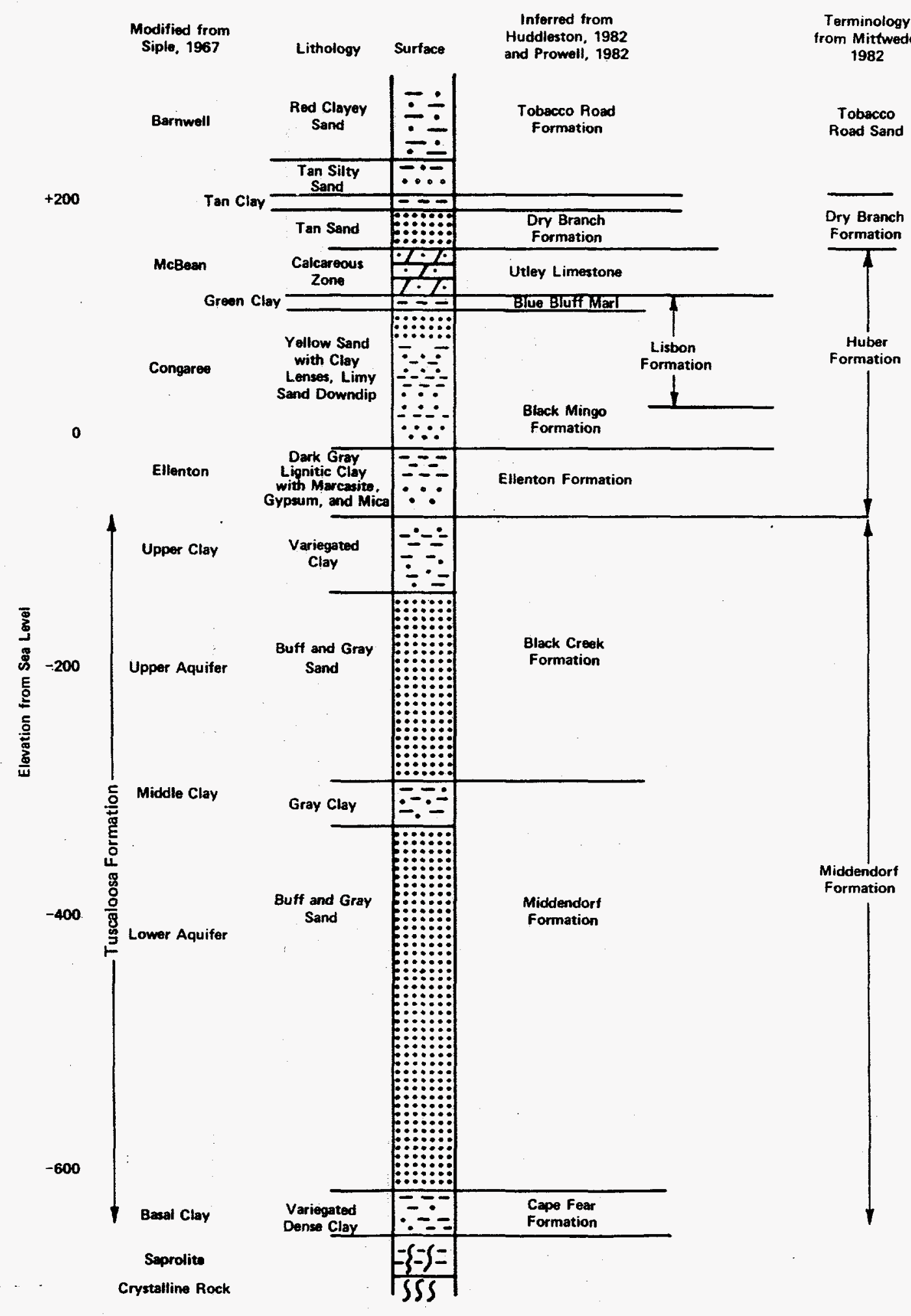

FIGURE 3-1. Tentative Correlation of Stratigraphic Terminology of the Southwestern South Carolina Coastal Plain 


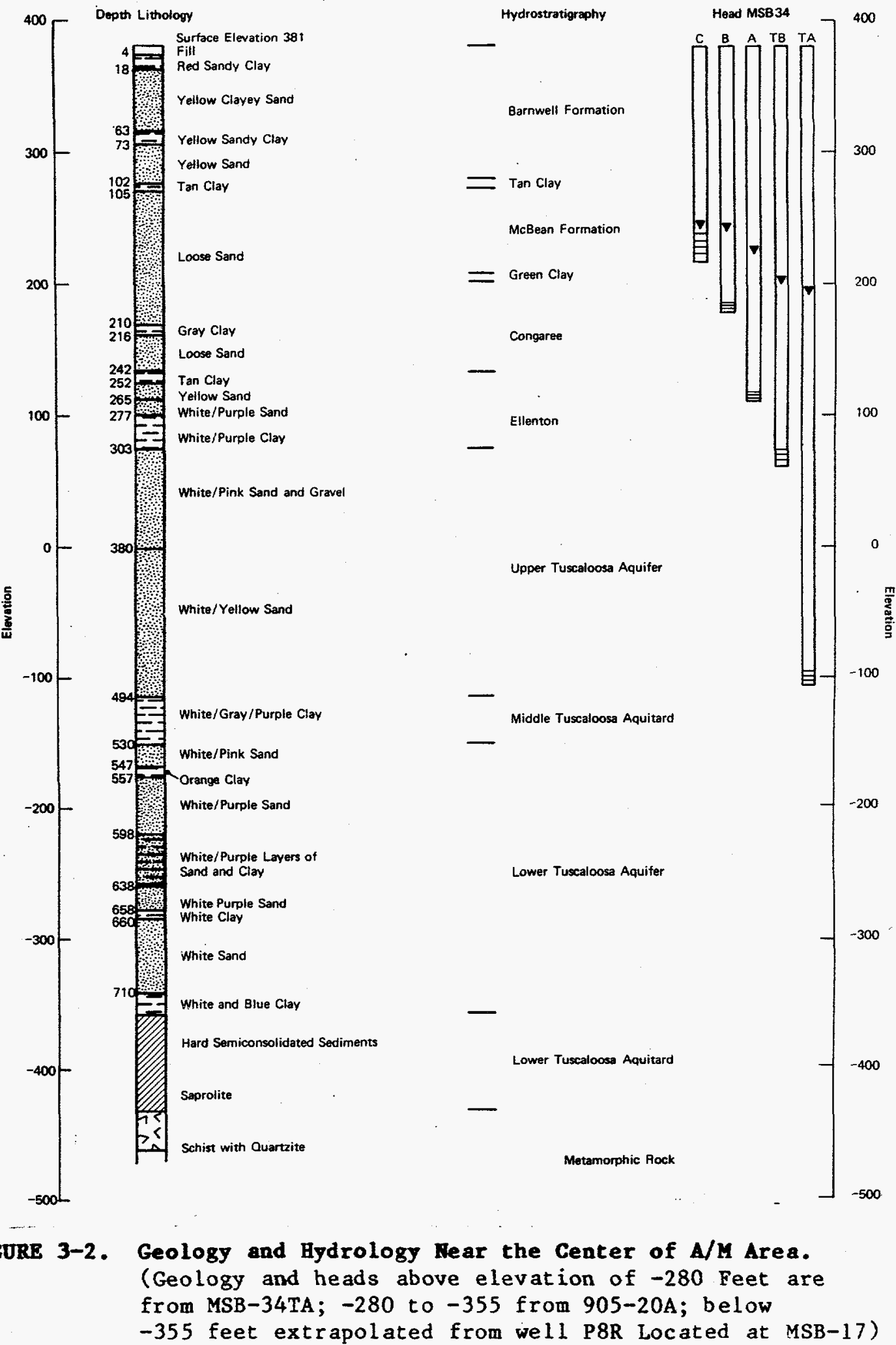




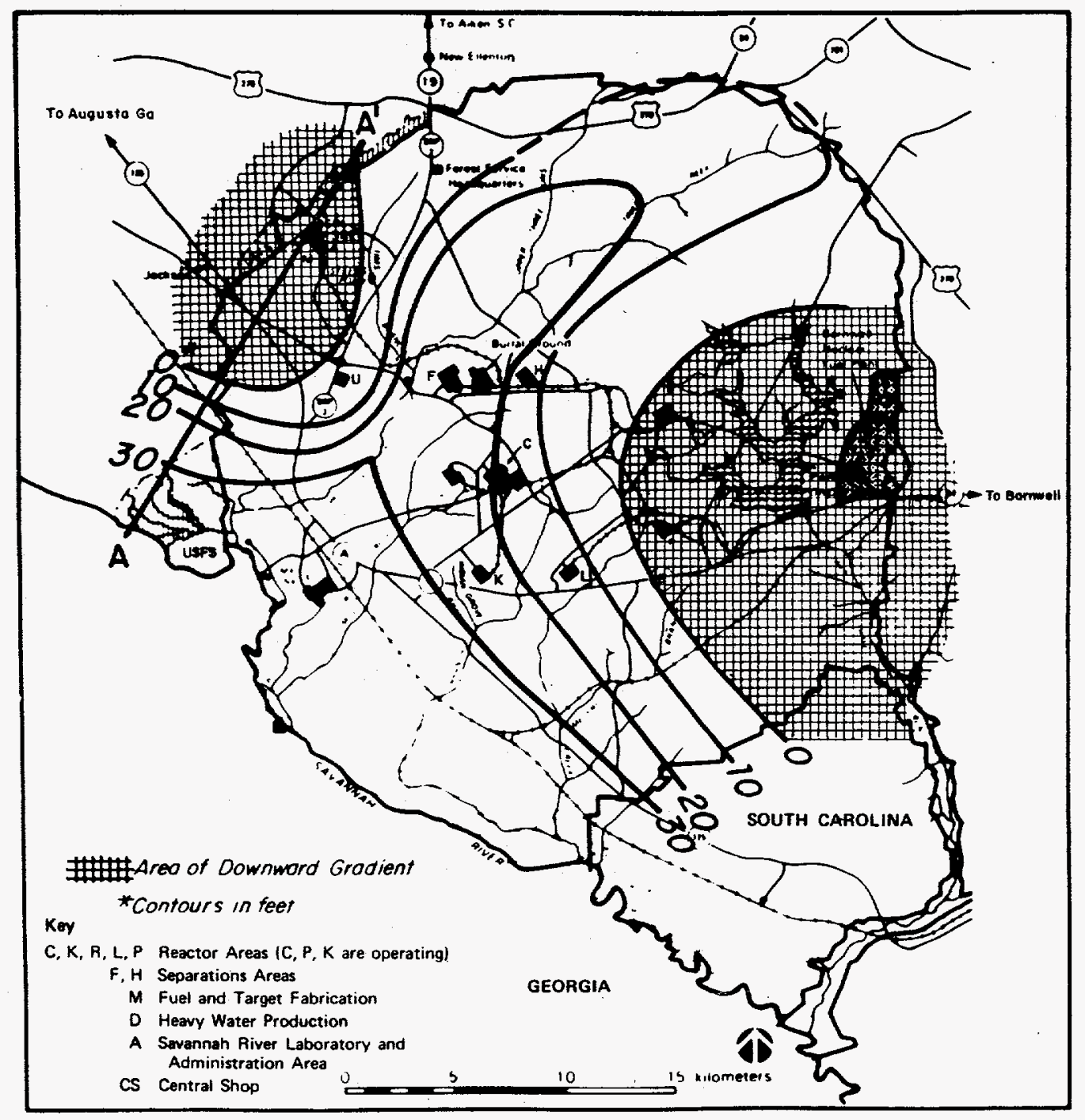

FIGURE 3-3. Generalized Head Difference Between the "Tuscaloosa" and Congaree Pormations at SRP. $A-A^{\prime}$ is Section Shown on Figure 3-4. 


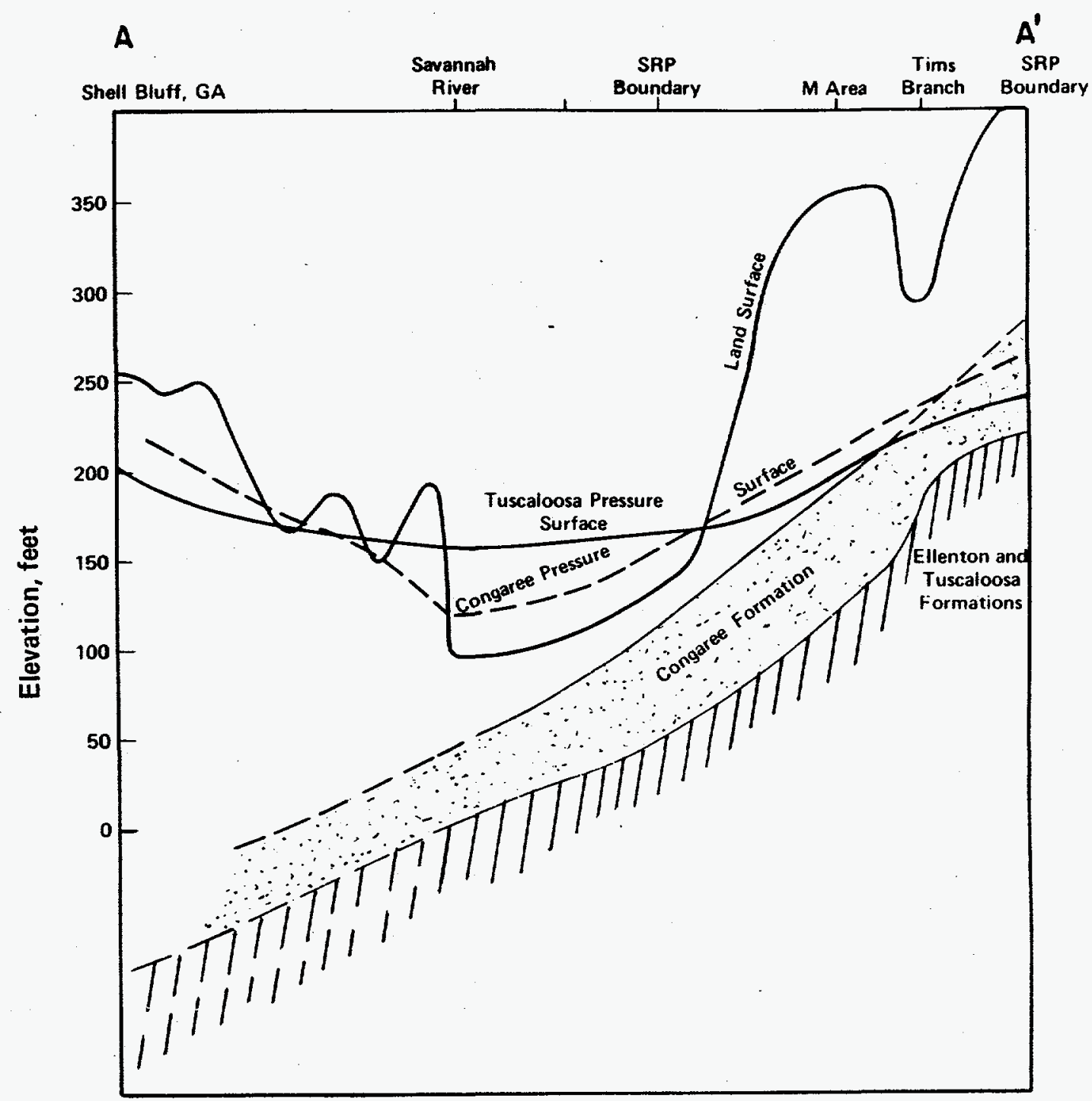

FIGURE 3-4. Hydrologic Section Perpendicular to the Savannah River Through Area. Location of Section is Shown on Figure 3-3. 


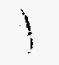

1

3-8 


\subsection{MONITORING WELL INSTALLATION}

Since the issuance of the Preliminary Technical Data Sumary (DPSTD-82-69) up to September 1, 1984, 27 additional monitoring wells were installed at eleven different drill sites. This brings to 74 the total number of monitoring wells completed as part of the M-Area groundwater investigation. The locations of all the well sites drilled up to September 1984 are shown on Figure 4-1. Clusters MSB-23 through 33 are the sites of the 27 wells drilled between August 1982 and August 1983. Table 4-1 gives the history of this drilling and subsequent drilling up to september 1984. A summary of the well installation data is given on Table 4-2. The well numbering system is discussed in Appendix A. Geologic borings drilled as part of this phase of the program range in depth from 45 to 660 feet with the monitoring well screens set at depths ranging between 45 and 485 feet below the ground surface. Seven of these wells are screened in the "Tuscaloosa" Formation. The locations of the seven "Tuscaloosa" monitoring wells are shown on Figure 4-2. Geologic samples for lithologic classification and, in certain borings, for chemical analysis were collected at each drill site utilizing either standard splitspoon samplers or wireline core barrels. In addition undisturbed samples were collected using a pitcher barrel sampler for laboratory determination of hydraulic conductivity, porosity, and grain size distribution. The und isturbed samples were collected mainly from the clays of the Ellenton and upper "Tuscaloosa" Formations. The results of the laboratory determinations are discussed in Section 5.3.1.

With increased concern for the possibility of contamination of new wells during drilling and installation operations, the procedure of steam cleaning both drilling materials (rods, bits, samplers, etc.) and casing, prior to use in each we11, was adopted as part of the standard well installation practice. This procedure was implemented for the installation of the last seven wells drilled to date (MSB-12TA, 12TB, 34TA, 34TB, 34A, 34B, and 34C). The procedure will continue to be used for all future wells drilled as part of the program.

Figure 4-1 also shows locations of wells drilled as part of other programs where data on water levels or chemical analyses in such wells are contributory to this program. Examples of such wells are "ASB", the wells near the Savannah River Laboratory seepage basins; "SRW", wells surrounding the Silverton Road waste site; "AOB", wells around the A-Area oil basin; ABG, A-Area background well; "ACB", wells around the A-Area coal pile runoff 
containment basin; and "AMB", wells around the metallurgical

laboratory basin. Most of these wells were installed near waste sites for monitoring purposes. "LA-4" is an early water production well in the "Tuscaloosa" Formation that was never used. Its number was changed to $905-4 \mathrm{M}$ in 1962 . Table 4-3 gives a summary of the well installation data for these wells.

As of September 1984, 58 additional monitoring wells in 14 clusters were scheduled to be installed in the Fall of 1984 and the Winter of 1985. (Editorial Note: These wells have been installed and water samples are currently being collected and analyzed.) Figure 4-3 shows the location of these clusters. In the Fall of 1984 well clusters $M S B-44,45$, and 46 were installed very close to production wells $905-82 \mathrm{~A}, 20 \mathrm{~A}$, and $31 \mathrm{~A}$, respectively, (Figure 4-2) to monitor the Tertiary sediment near these "Tuscaloosa" production we $11 \mathrm{~s}$. 
TABLE 4-1

History of Investigations of Groundwater Contamination in $A / M$ Area

Nov. 1979

to Feb. 1981

June 9, 1981

June 28,1981

July 21,1981

Dec. 1981

Mar. 1982

Apr./May 1982

Apr./May 1982

June 1982

Aug. 1982

Oct. 1982

Oct. 18 to

Nov. 17,1982

Feb. 1983
Installed RCRA type wells around M-Area settling basin (MSB-1 through 4), Lost Lake (MSB-5 through 8), A-Area coal pile runoff containment basin ( $A C B$ 1 through 4), SRL seepage basins (ASB 1 through 6 ), and Silverton Road waste site (SRW-1 through 6).

Collected first set of groundwater samples from these wells.

Analyses received. Contamination around M-Area settling basin and Silverton Road Waste Site by degreaser solvents first identified:

Began drilling first well to investigate contaminant plume from M-Area basin.

Completed 47 monitoring wells downgradient from basin including geologic sampling and testing for degreaser solvent contamination of soil (MSB-9 through 21).

Drilled five exploratory borings in M-Area settling basin.

Completed two rounds of water sampling in monitor wells.

Installed additional Silverton Road waste site monitor we1ls (SRW-7 through 11).

Installed M-Area Production Test Well MPT-1 and conducted 72-hour aquifer test. Installed MSB-22.

Completed six additional monitoring wells, three inside the M-Area perimeter fence and three just outside (MSB-23 through 28 ).

Issued Preliminary Technical Data Sumary, DPSTD-82-69.

Conducted 30-day aquifer test on MPT-1

Completed installation of 14 monitoring wells (at MSB-23 through 28 and MSB-30 through 33, Figure 4-1). 
TABLE 4-1, Contd

\begin{tabular}{|c|c|}
\hline Mar./Apr. 1983 & $\begin{array}{l}\text { Presence of degreaser solvents confirmed in A-Area Water } \\
\text { Production Wells } 905-53 \mathrm{~A} \text { and } 20 \mathrm{~A} \text {. }\end{array}$ \\
\hline Mar. 1983 & Began operation of Pilot Air Stripper with Well MPT-1. \\
\hline Apr. 23,1983 & $\begin{array}{l}\text { Conducted 33-hour aquifer test on "Tuscaloosa Well" } \\
\text { 905-20A. }\end{array}$ \\
\hline April-July 1983 & $\begin{array}{l}\text { Collected several rounds of water samples from monitor } \\
\text { wells. }\end{array}$ \\
\hline June-Aug. 1983 & $\begin{array}{l}\text { Installed well clusters in Tertiary and Cretaceous } \\
\text { sediments near Wel1 905-53A (MSB-34) and in the } \\
\text { Cretaceous at MSB-12. }\end{array}$ \\
\hline Nov. . 1983 & $\begin{array}{l}\text { Installed RWM- } 2 \text { and } 3 \text { and Demonstration Air Stripper } \\
\text { inside } M \text { Area. }\end{array}$ \\
\hline Aug.-Dec. 1983 & $\begin{array}{l}\text { Installed additional Silverton Road waste site monitor } \\
\text { wells in clusters }(\mathrm{SRW}-2,9 \text {, and } 12 \text { to } 16) \text {. }\end{array}$ \\
\hline Jan. 1984 & $\begin{array}{l}\text { Began operation of Demonstration Air Stripper with RWM-2 } \\
\text { and } 3 \text {. }\end{array}$ \\
\hline Apr. 1984 & $\begin{array}{l}\text { Silverton Road waste site and RCRA type wells added to } \\
\text { routine sampling schedule. }\end{array}$ \\
\hline May-July 1984 & Collected round of water samples from monitor wells. \\
\hline Sept. 1984 & $\begin{array}{l}\text { Installed Tertiary monitoring wells as close as possible } \\
\text { to "Tuscaloosa" production wells (MSB-44 at 905-82A, } \\
\text { MSB-45 at 905-20A, and MSB-46 at } 905-31 \mathrm{~A}) \text {. }\end{array}$ \\
\hline Sept. 1984 & $\begin{array}{l}\text { Beginning of program to install additional } 58 \text { monitoring } \\
\text { wells in } 14 \text { clusters to further refine the loc ation of the } \\
\text { cont aminant plume. (At ASB-8, MSB-27, MSB-30, and MSB-33. } \\
\text { New clusters MSB-29 and MSB-35 through 43.) }\end{array}$ \\
\hline
\end{tabular}


TABLE 4-2

M-Area Piezometer Installation Summary

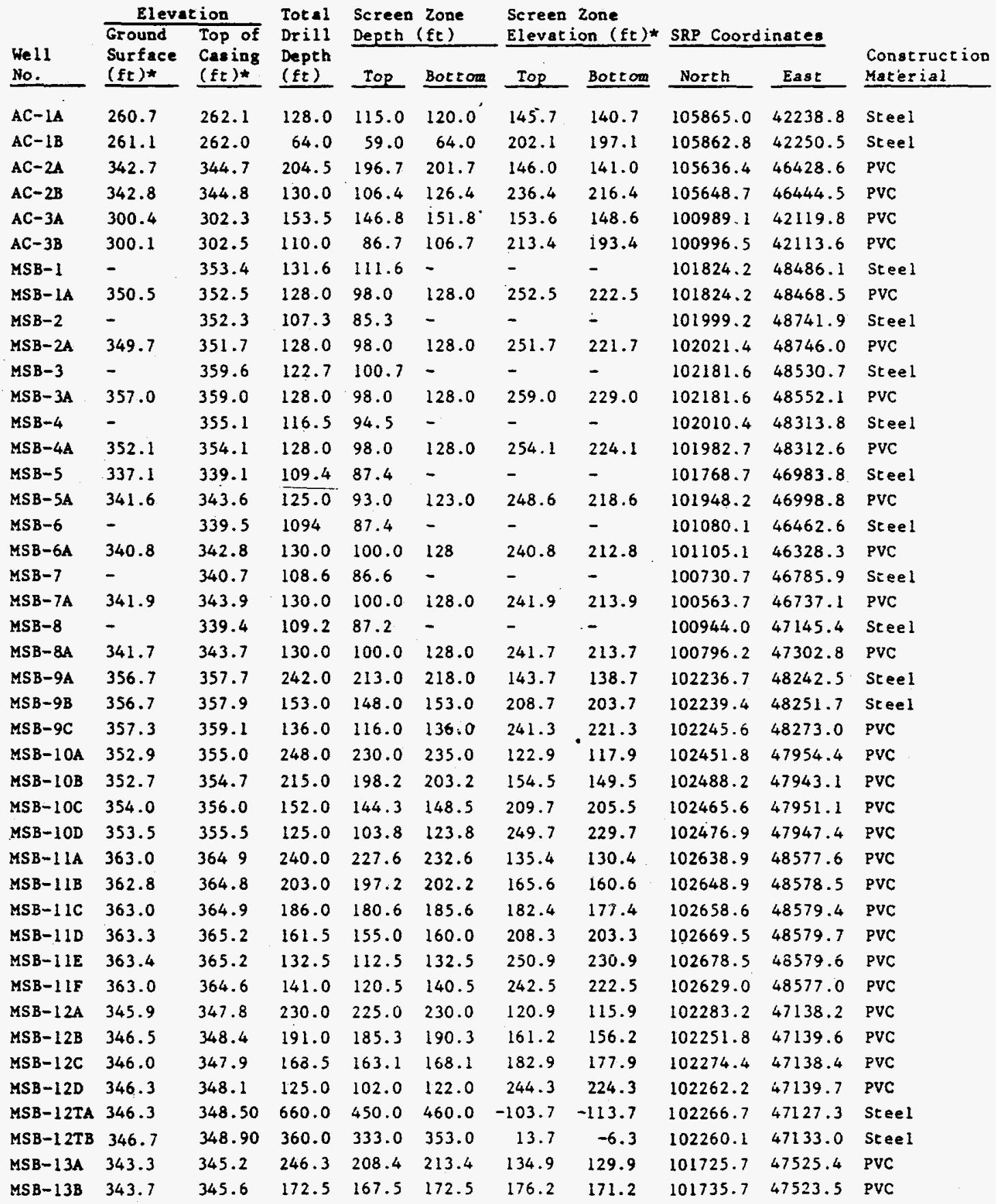

* Feet above (or below) mean sea level. 
TABLE 4-2, Contd

M-Area Piezometer Installation Summary

\begin{tabular}{|c|c|c|c|c|c|c|c|c|c|c|}
\hline \multirow{3}{*}{$\begin{array}{l}\text { Wel1 } \\
\text { No. }\end{array}$} & \multicolumn{2}{|c|}{ Elevation } & \multirow{3}{*}{$\begin{array}{l}\text { Total } \\
\text { Drill } \\
\text { Depth } \\
\text { (ft) } \\
\end{array}$} & \multirow{2}{*}{\multicolumn{2}{|c|}{$\begin{array}{l}\text { Screen Zone } \\
\text { Depth (ft) }\end{array}$}} & \multirow{2}{*}{\multicolumn{2}{|c|}{$\begin{array}{l}\text { Screen Zone } \\
\text { Elevation }(f t) *\end{array}$}} & \multirow{2}{*}{\multicolumn{2}{|c|}{ SRP Coordinates }} & \multirow{3}{*}{$\begin{array}{l}\text { Construction } \\
\text { Material }\end{array}$} \\
\hline & \multirow{2}{*}{$\begin{array}{l}\text { Ground } \\
\text { Surface } \\
(\mathrm{ft}) \star\end{array}$} & \multirow{2}{*}{$\begin{array}{l}\text { Top of } \\
\text { Casing } \\
\text { (ft)* }\end{array}$} & & & & & & & & \\
\hline & & & & Top & Botcom & Top & Bot tom & North & East & \\
\hline $\mathrm{MSB}-13 \mathrm{C}$ & 343.6 & 345.7 & 125.0 & 101.0 & 121.0 & 242.6 & 222.6 & 101745.7 & 47521.9 & PVC \\
\hline$M S B-14 A$ & 346.5 & 348.3 & 202.0 & 182.0 & 202.0 & 164.5 & 144.5 & 101629.5 & 48521.9 & PVC \\
\hline$M S B-14 B$ & 346.7 & 348.7 & 158.5 & 153.0 & 158.0 & 193.7 & 188.7 & 101639.0 & 48519.1 & PVC \\
\hline$M S B-14 C$ & 347.0 & 348.7 & 125.0 & 103.3 & 123.3 & 243.7 & 223.7 & 101648.6 & 48517.3 & PVC \\
\hline$M S B-15 A$ & 365.2 & 367.2 & 203.0 & 198.0 & 203.0 & 167.2 & 162.2 & 102983.5 & 48827.0 & PVC \\
\hline$M S B-15 C$ & 364.6 & 366.6 & 125.0 & 104.2 & 124.2 & 260.4 & 240.4 & 103002.1 & 48834.0 & PVC \\
\hline$M S B-16 A$ & 364.9 & 366.7 & 203.7 & 198.7 & 203.7 & 166.2 & 161.2 & 103693.9 & 48965.1 & PVC \\
\hline$M S B-16 C$ & 365.0 & 366.6 & 141.0 & 121.0 & 141.0 & 244.0 & 224.0 & 103714.1 & 48970.5 & PVC \\
\hline$M S B-17 A$ & 356.3 & 358.0 & 201.8 & 196.7 & 201.7 & 159.6 & 154.6 & 101976.6 & 46245.7 & PVC \\
\hline$M S B-17 B$ & 356.4 & 357.9 & 172.0 & 166.4 & 171.4 & 190.0 & 185.0 & 101994.6 & 46237.7 & PVC \\
\hline$M S B-17 C$ & 356.3 & 358.1 & 125.0 & 103.0 & 123.0 & 253.3 & 233.3 & 102004.6 & 46234.3 & PVC \\
\hline$M S B-18 A$ & 338.3 & 340.2 & 200.4 & 176.0 & 181.0 & 162.3 & 157.3 & 100416.1 & 46110.4 & PVC \\
\hline$M S B-18 B$ & 338.5 & 340.3 & 167.0 & 141.5 & 146.5 & 197.0 & 192.0 & 100424.1 & 46115.7 & PVC \\
\hline$M S B-18 C$ & 338.5 & 340.6 & 131.5 & 111.2 & 131.2 & 227.3 & 207.3 & 100430.9 & 46121.4 & PVC \\
\hline$M S B-19 A$ & 298.1 & 299.5 & 200.9 & 178.5 & 183.5 & 119.6 & 114.6 & 100983.0 & 50934.4 & PVC \\
\hline$M S B-19 B$ & 298.2 & 299.9 & 155.8 & 150.8 & 155.8 & 147.4 & 142.4 & 100999.3 & 50934.8 & PVC \\
\hline$M S B-19 C$ & 298.1 & 300.2 & 101.0 & 80.0 & 100.0 & 218.1 & 198.1 & 100992.1 & 50942.4 & PVC \\
\hline$M S B-20 A$ & 351.9 & 354.0 & 202.0 & 190.7 & 195.7 & 161.2 & 156.2 & 103545.1 & 46060.5 & PVC \\
\hline$M S B-2 O C$ & 351.2 & 353.3 & 142.0 & 118.8 & 138.8 & 232.4 & 212.4 & 103556.3 & 46088.8 & PVC \\
\hline$M S B-21 A$ & 351.2 & 353.4 & 202.0 & 193.4 & 198.4 & 157.8 & 152.8 & 103967.0 & 47217.2 & PVC \\
\hline$M S B-21 C$ & 351.6 & 353.4 & 140.0 & 119.8 & 139.8 & 231.8 & 211.8 & 103973.0 & 47234.6 & PVC \\
\hline MSB-22 & 356.7 & 359.0 & 200.0 & 115.0 & 135.0 & 241.7 & 221.7 & 102186.5 & 48508.8 & PVC \\
\hline MSB-23 & 370.4 & 371.77 & 252.0 & 120.0 & 140.0 & 250.4 & 230.4 & 104312.0 & 49294.0 & Pvc \\
\hline$M S B-23 A$ & 370.4 & 371.52 & 318.0 & 308.0 & 318.0 & 62.4 & 52.4 & 104314.9 & 49290.7 & PVC \\
\hline$M S B-23 B$ & 370.1 & 371.60 & 199.0 & 194.0 & 199.0 & 176.1 & 171.1 & 104336.6 & 49286.4 & PVC \\
\hline MSB-24 & 378.9 & 380.15 & 251.0 & 135.0 & 155.0 & 243.9 & 223.9 & 104614.4 & 49842.9 & PVC \\
\hline$M S B-24 A$ & 379.9 & 381.58 & 210.0 & 200.0 & 210.0 & 178.8 & 168.8 & 104625.3 & 49845.3 & PVC \\
\hline MSB-25 & 364.7 & 366.93 & 251.0 & 120.0 & 140.0 & 244.7 & 224.7 & 103498.8 & 49668.9 & PVC \\
\hline$M S B-25 A$ & 364.7 & 366.42 & 207.0 & 195.0 & 205.0 & 169.7 & 159.7 & 103504.8 & 49657.9 & PVC \\
\hline MSB-26 & 359.5 & 361.55 & 202.0 & 119.0 & 139.0 & 240.5 & 220.5 & 104612.8 & 48941.7 & PVC \\
\hline$M S B-26 A$ & 359.2 & 360.93 & 190.0 & 180.0 & 190.0 & 179.2 & 169.2 & 104602.3 & 48440.7 & PVC \\
\hline HSB- 27 & 374.0 & 375.48 & 200.0 & 130.0 & 150.0 & 244.0 & 234.0 & 104972.8 & 49487.7 & PVC \\
\hline$M S B-27 A$ & 373.8 & 375.15 & 182.0 & 170.0 & 180.0 & 203.8 & 193.8 & 104962.8 & 49487.8 & PVC \\
\hline MSB- 28 & 352.6 & 354.41 & 200.0 & 122.0 & 142.0 & 230.6 & 210.6 & 104941.8 & 48517.3 & PVC \\
\hline$M S B-28 A$ & 352.6 & 354.23 & 200.0 & 195.0 & 200.0 & 157.6 & 152.6 & 104947.7 & 48521.9 & PvC \\
\hline$M S B-30 A$ & 352.6 & 354.56 & 326.0 & 316.0 & 326.0 & 36.6 & 26.6 & 105727.4 & 48004.1 & PVC \\
\hline$M S B-30 C$ & 352.2 & 354.04 & 135.0 & 115.0 & 135.0 & 237.2 & 217.2 & 105731.1 & 48013.7 & PVC \\
\hline$M S B-31 A$ & 346.0 & 347.20 & 334.0 & 324.0 & 334.0 & 22.0 & 12.0 & 101979.3 & 50100.2 & PVC \\
\hline$M S B-31 B$ & 346.2 & $347_{.} .50$ & 194.0 & 189.0 & 194.0 & 157.2 & 152.2 & 101981.3 & 50078.7 & PVC \\
\hline$M S B-31 C$ & 346.0 & 347.30 & 130.0 & 110.0 & 130.0 & 236.0 & $216.0^{\circ}$ & 101979.6 & 50089.9 & PVC \\
\hline$M S B-32$ & 252.7 & 255.26 & 57.0 & 35.0 & 55.0 & 217.7 & 197.7 & 99655.6 & 52733.9 & PVC \\
\hline$M S B-33$ & 254.3 & 256.63 & 45.0 & 25.0 & 45.0 & 229.3 & 209.3 & 98031.0 & 51736.3 & PVC \\
\hline$M S B-34 A$ & 381.8 & 383.17 & 273.5 & 263.5 & 268.5 & 118.3 & 113.3 & 104954.9 & 50534.9 & PVC \\
\hline$M S B-34 B$ & 381.8 & 383.08 & 205.0 & 195.0 & 200.0 & 186.8 & 181.8 & 104944.7 & 50534.9 & PVC \\
\hline$M S B-34 C$ & 381.7 & 383.19 & 166.0 & 141.0 & 161.0 & 240.7 & 220.7 & 104934.1 & 50535.5 & PVC \\
\hline$M S B-34 T A$ & 381.0 & 382.49 & 660.0 & 473.7 & 483.7 & -92.7 & -102.7 & 104905.8 & 50536.6 & Steel \\
\hline$M S B-34 T B$ & 381.8 & 382.77 & .320 .0 & 306.0 & 316.0 & 75.8 & 65.8 & 104891.6 & 50537.9 & Steel \\
\hline
\end{tabular}

* Feer sbove (or below) mean sea level. 
TABLE 4-3

Piezometer Installation Data Summary for Wells from other Program Used to Collect Information for M-Area Investigations

\begin{tabular}{|c|c|c|c|c|c|c|c|c|c|c|}
\hline \multirow[b]{2}{*}{$\begin{array}{l}\text { Well } \\
\text { No. }\end{array}$} & \multirow{2}{*}{$\begin{array}{l}\text { Elevat is } \\
\text { Ground } \\
\text { Surface } \\
(\mathrm{ft}) *\end{array}$} & \multirow{2}{*}{$\begin{array}{l}\text { Top of } \\
\text { Casing } \\
\text { (ft)* }\end{array}$} & \multirow{2}{*}{$\begin{array}{l}\text { Total } \\
\text { Drill } \\
\text { Depth } \\
\text { (ft) } \\
\end{array}$} & \multicolumn{2}{|c|}{$\begin{array}{l}\text { Screen Zone } \\
\text { Depth (ft) }\end{array}$} & \multicolumn{2}{|c|}{$\begin{array}{l}\text { Screen Zone* } \\
\text { Elevation ( } f t)\end{array}$} & \multicolumn{2}{|c|}{ SRP Coordinates } & \multirow[b]{2}{*}{$\begin{array}{l}\text { Construction } \\
\text { Material }\end{array}$} \\
\hline & & & & Top & Bottom & Top & Bottom & North & East & \\
\hline$A B G-1$ & 323.1 & 324.8 & 138 & 108 & 138 & 215 & 185 & 105939.9 & 55016.4 & PVC \\
\hline$A C B-2 A$ & 347.7 & 349.8 & 140.0 & 110.0 & 140.0 & 237.7 & 207.7 & 102367.4 & 51561.3 & PVC \\
\hline$A C B-3 A$ & 357.5 & 348.3 & 140.0 & 110.0 & 140.0 & 247.5 & 217.5 & 102154.3 & 51313.3 & PVC \\
\hline AMB-2 & 377.0 & 379.3 & 155.0 & 125.0 & 155.0 & 252.0 & 222.0 & 104164.6 & 51517.9 & PVC \\
\hline $\mathrm{AOB}-1$ & 338.5 & 341.07 & 120.0 & 90.0 & 120.0 & 248.5 & 218.5 & 101910.7 & 50485.9 & PVC \\
\hline $\mathrm{AOB}-2$ & 343.2 & 345.4 & 125.0 & 93.0 & 123.0 & 250.2 & 220.2 & 102009.8 & 50724.7 & PVC \\
\hline$A S B-1 A$ & 347.1 & 349.1 & 130.0 & 100.0 & 130.0 & 247.1 & 217.1 & 105535.0 & 52614.0 & PVC \\
\hline$A S B-2 A$ & 347.0 & & 130.0 & 100.0 & 130.0 & 247.0 & 217.0 & 105608.8 & 52856.9 & PVC. \\
\hline ASB-3 & 343.2 & 345.2 & 125.0 & 93.0 & 125.0 & 250.2 & 218.2 & 105712.4 & 52989.0 & PVC \\
\hline ASB -4 & 333.6 & 335.6 & 107.0 & 74.5 & 107.0 & 259.1 & 226.6 & 105840.8 & 53109.9 & PVC \\
\hline ASB-5A & 342.9 & 345.0 & 125.0 & 95.0 & 125.0 & 247.9 & 217.9 & 105885.5 & 52865.7 & PVC \\
\hline ASB-6 & 348.2 & 350.0 & 130.0 & 100.0 & 130.0 & 248.2 & 218.2 & 105716.0 & 52675.9 & PVC \\
\hline $\mathrm{ASB}-7$ & 351.2 & 353.4 & 140 & 120 & 140 & 231 & 211 & 105771 & 52626.4 & PVC \\
\hline ASB-8 & 346.6 & 348.9 & 140 & 120 & 140 & 227 & 207 & 106382 & 53136.6 & PVC \\
\hline ASB-9 & 306.4 & 308.9 & 90 & 70 & 90 & 236 & 216 & 104589 & 54226.2 & PVC \\
\hline LA-4 & 357 & 357 & 670 & 390 & 600 & -33 & -243 & 102131.7 & 46226.7 & Steel \\
\hline$s-15$ & 340 & & 165 & & 165 & & 175 & 105557.5 & 47096.8 & Steel \\
\hline SRW-IC & 313.2 & 315.2 & 115 & 83 & 113 & 230.2 & 200.2 & 103706.1 & 41391.1 & PVC \\
\hline SRW $-2 C$ & 318.6 & 320.6 & 120 & 88 & 118 & 230.6 & 200.6 & 103653.2 & 41611.9 & PVC \\
\hline SRW-3C & 329.4 & 331.4 & 123 & 91 & 121 & 238.4 & 208.4 & 103463.6 & 41830.4 & PVC \\
\hline SRW-4C & 316.1 & 318.1 & 120 & 88 & 118 & 228.1 & 198.1 & 103240.8 & 41600.2 & PVC \\
\hline SRW-5C & 305.3 & 307.3 & 115 & 83 & 113 & 222.3 & 192.3 & 103346.0 & 41227.2 & PVC \\
\hline SRH-6C & 306.6 & 308.6 & 115 & 83 & 113 & 223.6 & 193.6 & 103530.7 & 41229.3 & PVC \\
\hline$S R H-7 C$ & 295.1 & 297.1 & 101.2 & 81.2 & 101.2 & 213.9 & 193.9 & 103466.6 & 40913.3 & PVC \\
\hline SRH-8C & 284.2 & 286.2 & 93.0 & 71.0 & 93.0 & 213.2 & 191.2 & 103390.9 & 40438.7 & PVC \\
\hline$S R W-9 C$ & 249.3 & 251.3 & 87.0 & 55.0 & 87.0 & 194.3 & 162.3 & 102516.7 & 41914.1 & PVC \\
\hline SRW-10C & 294.7 & 296.7 & 108.0 & 76.0 & 108.0 & 218.7 & 186.7 & 103615.2 & 40857.9 & PVC \\
\hline SRW-11C & 302.2 & 304.2 & 103.0 & 73.0 & 103.0 & 229.2 & 199.2 & 103310.5 & 40933.1 & PVC \\
\hline SRN-2A & 319.43 & 320.92 & 235.8 & 220.7 & 230.5 & 98.7 & 88.9 & 103724.71 & 41634.96 & PVC \\
\hline SRW-2B & 319.56 & 320.93 & 171.5 & 156.6 & 166.4 & 163.0 & 153.2 & 103733.63 & 41632.08 & PVC \\
\hline SRW-9A & 251.74 & 253.69 & 142.4 & 127.1 & 137.0 & 124.6 & 114.7 & 103256.60 & 39692.74 & PVC \\
\hline SRW-9B & 252.11 & 253.79 & 104.0 & 89.3 & 99.1 & 162.8 & 153.0 & 103247.04 & 39697.31 & PVC \\
\hline SRH-1.2A & 234.58 & 236.78 & 135.6 & 120.4 & 130.2 & 114.2 & 104.4 & 103716.57 & 39013.36 & PVC \\
\hline SRW-12B & 234.54 & 236.77 & 92.7 & 78.0 & 87.8 & 156.5 & 146.7 & 103708.92 & 39020.42 & PVC \\
\hline SRW-12C & 234.76 & 236.77 & 60.1 & 35.4 & 55.2 & 199.4 & 179.6 & 102990.82 & 40682.42 & PVC \\
\hline SRW-1 $3 A$ & 295.98 & 298.10 & 207.3 & 192.1 & 201.9 & 103.9 & 94.1 & 103005.38 & 40668.03 & PVC \\
\hline SRH-13B & 296.11 & 298.05 & 147.2 & 132.5 & 142.4 & 163.6 & 153.7 & 102997.93 & 40675.45 & PVC \\
\hline SRW-13C & 296.30 & 298.02 & 105.1 & 70.5 & 100.1 & 225.8 & 196.4 & 102990.82 & 40682.42 & PVC \\
\hline RW & 325 & 327.33 & 221.0 & $\begin{array}{l}201.2 \\
214.0\end{array}$ & $\begin{array}{l}211.0 \\
217.0\end{array}$ & 124.1 & 108.3 & 102835.12 & 41538.18 & PVC \\
\hline SRN-14B & 325.27 & 327.23 & 177.2 & 162.0 & 171.8 & 163.3 & 153.5 & 102839.83 & 41548.55 & PVC \\
\hline$S R W-14 C$ & 325.75 & 327.42 & 132.1 & 97.0 & 126.7 & 228.7 & 199.0 & 102827.90 & 41546.04 & PVC \\
\hline SRH-15A & 317.76 & 319.51 & 224.6 & 209.8 & 219.6 & 108.0 & 98.2 & 104547.28 & 41608.37 & PVC \\
\hline SRW-15B & 317.45 & 319.50 & 173.1 & 155.5 & 165.3 & 162.0 & 152.2 & 104552.55 & 41590.51 & PVC \\
\hline$S R W-15 C$ & 317.67 & 319.51 & 135.1 & 100.0 & 129.6 & 217.7 & 188.1 & 104550.34 & 41698.12 & PVC \\
\hline SRW-16A & 344.90 & 347.07 & 229.6 & 200.4 & 225.1 & 144.5 & 119.8 & 103766.25 & 42831.80 & PVC \\
\hline$S R W-16 B$ & 344.63 & 347.07 & 190.4 & 174.5 & 184.3 & 170.1 & 160.3 & 103774.82 & 42826.67 & PVC \\
\hline SRW-16C & 345.83 & 347.07 & 148.8 & 109.6 & 139.6 & 236.2 & 206.2 & 103772.38 & 42841.77 & PVC \\
\hline
\end{tabular}

* Elevation above or below $(-)$ mean sea level 


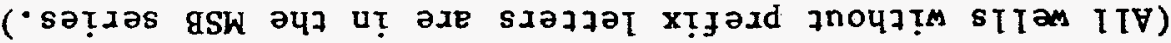

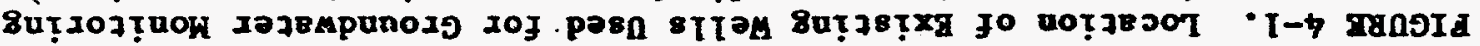

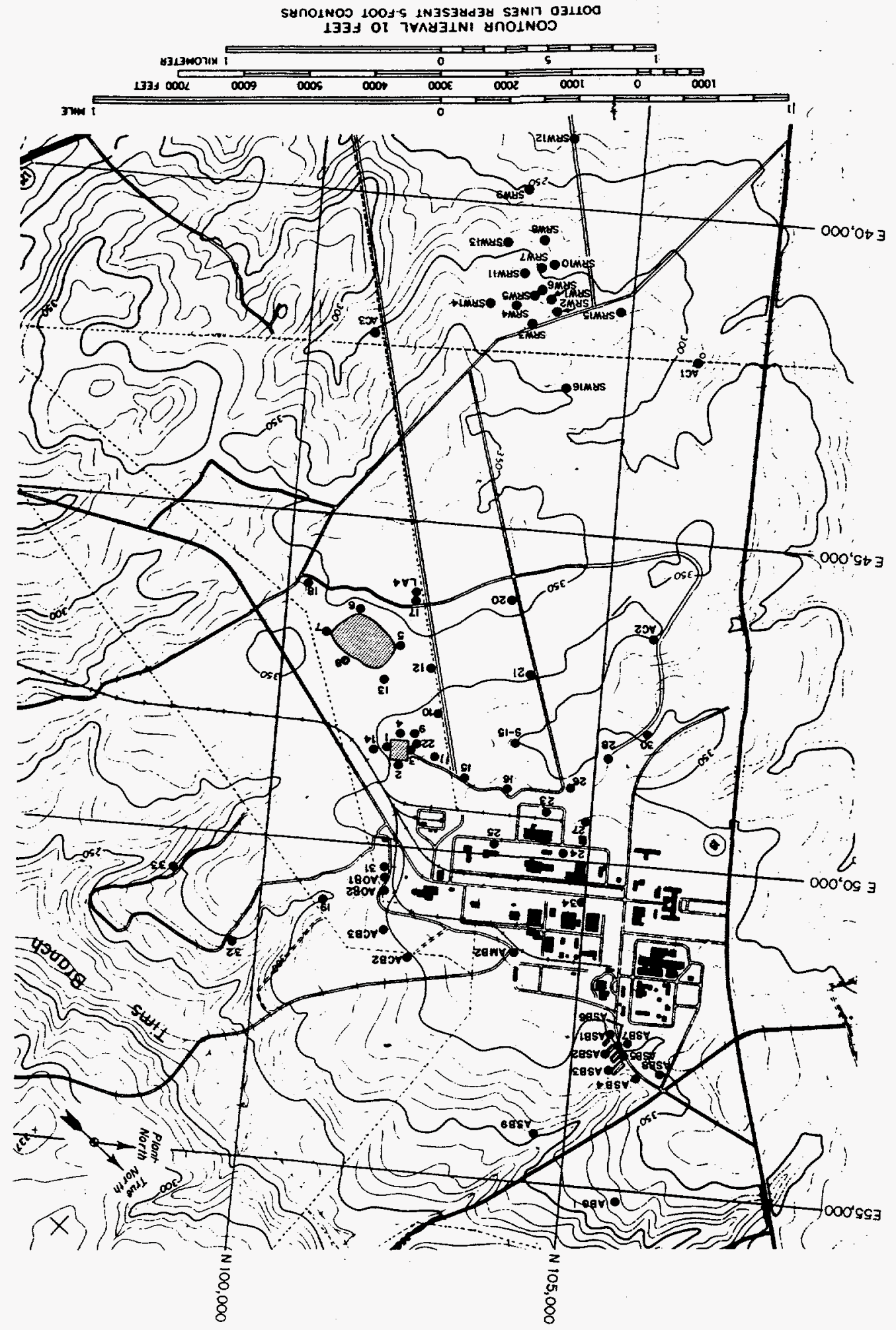




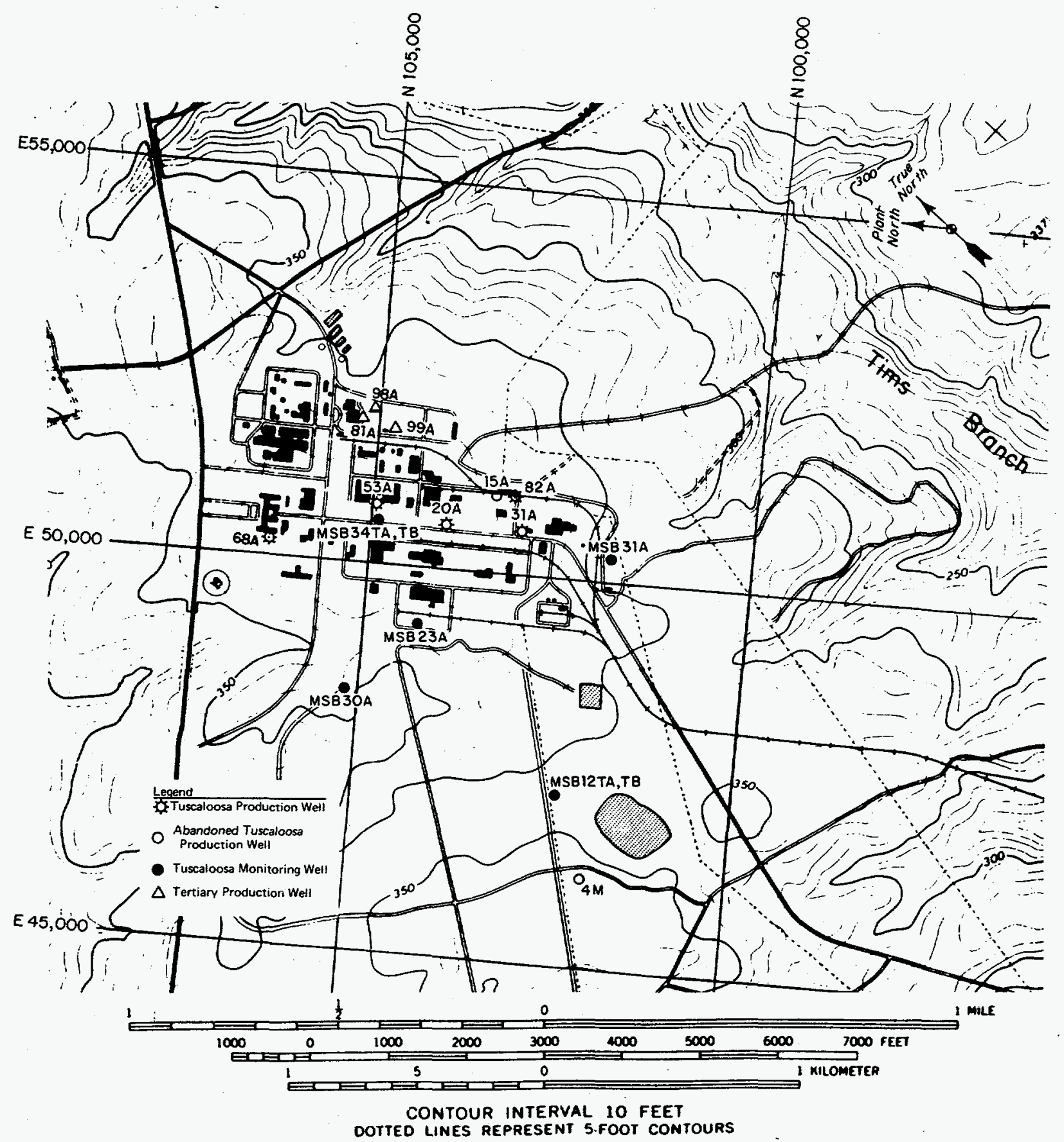

FIGURE 4-2. Location of Production and Monitoring Wells Screened in the "Tuscaloosa" Formation Near Area and Production Wells Screened in the Tertiary Sediments 


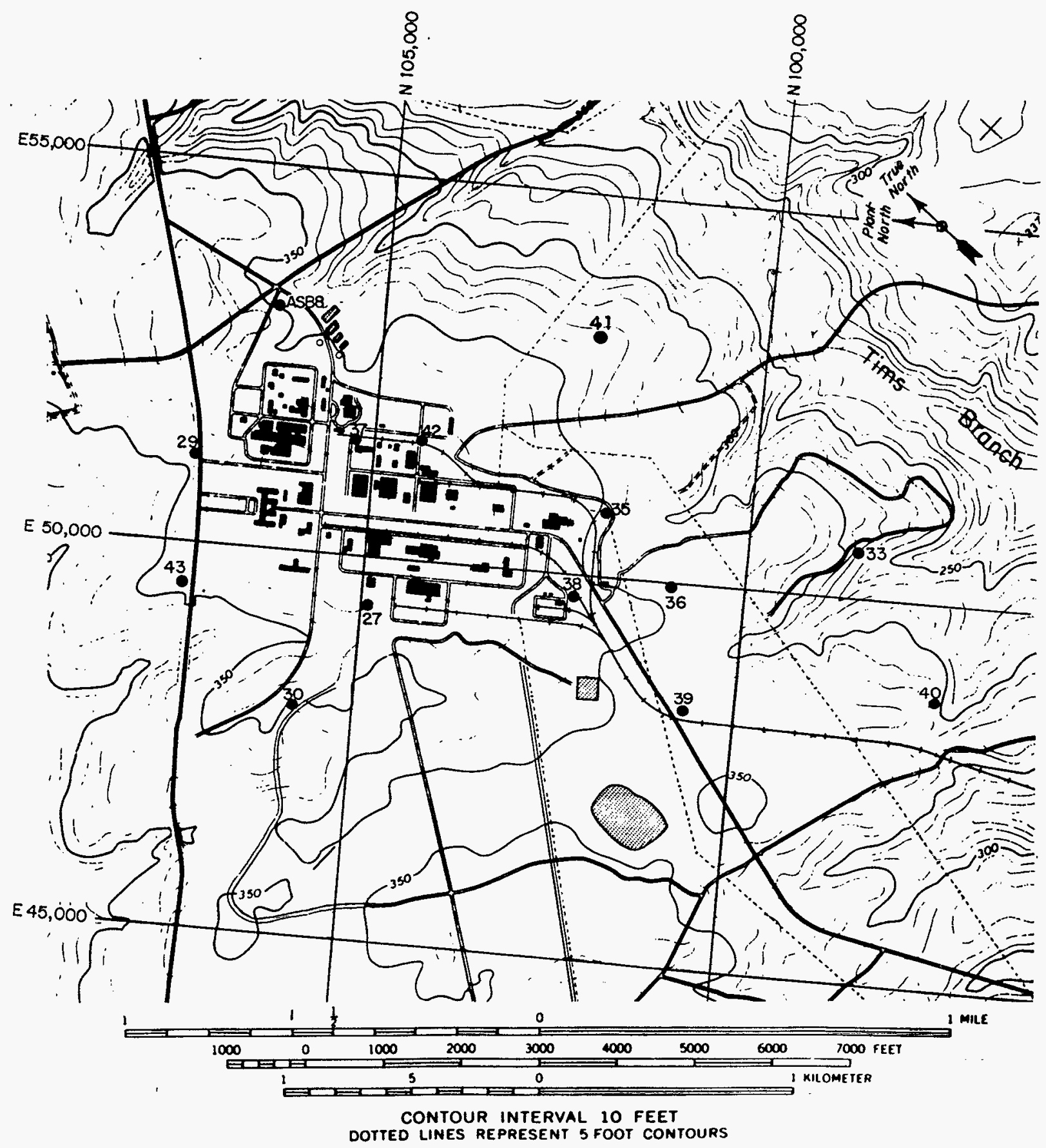

FIGURE 4-3. Location of Proposed Konitoring Well clusters

(Clusters are MSB unless Otherwise Noted) 


\subsection{Geology}

Knowledge of the subsurface geology in the M-Area vicinity was increased significantly with the coring of two borings (MSB-12TA and 34TA) into the lower "Tuscaloosa" Formation (Geraghty \& Miller, Inc., 1984). These two borings provided geologic samples from the ground surface to a depth of 660 feet. In addition to providing detailed lithologic logs of the underlying sediments, each boring was also geophysically logged. Geophysical logs obtained include resistivity, gamma ray, neutron, self potential, and caliper. The data obtained from these logs allows more effective extrapolations to be made for zones from which little or no material was recovered during sampling, enabling more effective identification of high permability zones in the formation and optimum selection of screen zones.

The undifferentiated Tertiary age sediments (i.e., Barnwell, McBean, and Congaree Formations) are approximately 250 feet in thickness, and overlie the Ellenton Formation of Cretaceous age (or as now appears more probable, Paleocene age) which is on the order of 40 to 60 feet in thickness and is found between depths of $\sim 240$ to 300 feet below the ground surface (Figure 3-2). The Ellenton Formation consists characteristically of dark-gray to black sandy lignitic micaceous clay interbedded with medium to coarse sand. However, the presence of distinct dark gray clays characteristic of the El lenton Formation was not encountered in each boring that penetrated into the "Tuscaloosa" Formation. In the absence of these dark clays it is difficult to visually distinguish the contact between the Ellenton and the Congaree Formations above and the "Tuscaloosa" Formation below. In the areas where characteristic Ellenton lithologies were not penetrated it is probably due to the fact that $M$ Area is located near the northernmost extension of the formation which is shown pinching out by Siple (1967) along the northwest boundary of SRP. Where these dark clays are present, the Ellenton can generally be easily distinguished from the underlying variegated clays of the upper "Tuscaloosa" Formation.

In general the "Tuscaloosa" is found at a depth of approximately 300 feet below the ground surface in the M-Area vicinity (Figure 3-2). The "Tuscaloosa" Formation consists of beds of fine to coarse grained quartz sand and gravel interbedded and intercalated with kaolonitic clays and silts. The results of both the geologic sampling and the geophysical logging indicate that the "Tuscaloosa" $c$ an be divided into two hydrogeologic units, an upper 
and lower, separated by relatively thick clay units on the order of 35 to 40 feet in thickness between depths of approximately 490 and 530 feet below the ground surface. The continuity of this aquitard is not known although it is present at other drill locations across the plantsite (Figure 3-1). The zone is more of a distinct clay unit at drill site MSB-34 than at MSB-12 where the zone is more of a heterogeneous mixture of clays and sandy, silty clays. Figure 5-1 is a geologic section incorporating three of the "Tuscaloosa" borings sites (MSB-34, MSB-23 and MSB-12). The section is along a north-south line (Figure 4-2) slightly off the regional dip which is to the southeast.

\subsection{Subsurface Hydrology}

\subsubsection{Recharge}

It is presumed that in a small area, such as the $A / M$ Area, rain falls uniformly over the entire area. Although this may not be true for individual storms, especially summer thunderstorms, it is undoubtedly true when averaged over a year. The effect of rainfall on recharge to the groundwater is probably even more uniform in space due to the attenuation of individual rainfall events in passing through the unsaturated zone, which is greater than 100 feet thick in the $\mathrm{A} / \mathrm{M}$ Area. Although buildings and parking lots may cause some redistribution of the entry of rainfall into the ground, this probably does not have a major effect on groundwater recharge. The water diverted from a building or parking lot usually is not transported far from the facility before discharging to the ground. Thus the effect would be quite local even without the attenuation caused by the greater than 100-foot depth to the water table.

The same statements cannot be made about water discharges that do not originate with immediate rainfall. For example, process and cooling water pumped from the "Tuscaloosa" Formation passes through M-Area facilities and is discharged to the M-Area settling basin, thence to a seep area, and on to Lost Lake or to the A-14 or M-2 outfalls (Figure $5-2$ ). These seepage areas provide a continuous recharge to the water table in this particular locality, which is not present in the general area. Thus, this factor probably influences to some extent the shape of water table contours. Figure 5-2 shows the surface locations of seepage areas where water has historically entered the ground in addition to the rainfall that is presumed to be evenly distributed over the area.

The sewer outfall at A-14 receives storm runoff and noncontact cooling water. In addition the $A-14$ outfall receives storm runoff and noncontact cooling water pumped from outfall $M-2$ up to a maximum of 650 gallons per minute, which has been the limit of the lift 
station pumps. Above this maximum the water discharges from $M-2$ outfall and spreads out as shown on Figure 5-2. A project is in progress to increase the capacity of the lift station pumps to $950 \mathrm{gpm}$. When this is completed water will rarely overflow to $\mathrm{M}-2$. In the past $A-14$ has been an important receiver of process sewer waste as well as noncontact cooling water and storm runoff. Initially all process wastes (Buildings $313-M$ and $320-M$ ) went to A-14. Building 321-M was completed in 1957, and to prevent uranium discharges to surface streams, the settling basin was built and began receiving process waste discharges from Building $321-M$. The discharges to the M-Area basin were increased in 1973 and again in 1976, when portions of Building 313-M were tied into the settling basin effluent pipeline to reduce uranium discharges to Tims Branch. Consequently the discharge to the A-14 outfall decreased. In order to eliminate the discharge of low $\mathrm{pH}$ water to surface streams, all effluents (including 320-M) except for noncontact cooling water were rerouted to the settling basin on May 22, 1982.

After one or two years of use (i.e., 1960) the settling basin became partially plugged to water seepage and began to overflow along a ditch that went to Lost Lake. Usually the overflow reached Lost Lake, but occasionally all of the basin overflow seeped into the ground in a low spot between the settling basin and Lost Lake. This was the case in 1979 when the average discharge was about $330 \mathrm{gpm}$ (Martin, 1984) and Lost Lake was completely dry. After the diversion of all process water from A-14 to the settling basin, the flow was about $550 \mathrm{gpm}$ and Lost Lake began to fill. Noncontact cooling water was segregated and sent to outfalls $A-14$ and $M-2$ in August 1982. In late September 1982 the depression receiving the water from M-2 began to fill, and water began to spread to the northwest and southwest. In December 1982 a pump was installed to divert water from $M-2$ outfall to $A-14$, but the depression still receives storm runoff and noncontact cooling water that is in excess of the pumping capacity (650 $\mathrm{gpm}$ ), which occurs only during thunderstorms.

As shown on Figure 5-2 water is discharged from the northern part of A Area through the A-1,A-3, A-4, and A-5 out falls to another tributary to Tims Branch. Several outfalls (A-7, A-8, A-9, and $A-11$ ) in the northeastern part of $A$ Area drain to a standing body of water.

Several studies of groundwater recharge have been made in the vicinity of SRP, using regional base stream flow (Cahill, 1982; Hubbard, 1984; Parizek and Root, 1984). These studies all conclude that the recharge is about 15 inches per year. In the absence of specific studies or detailed knowledge of the recharge in $A / M$ Area, it is presumed that 15 inches per year is applicable to this area also. 
Recharge to the water table could be affected by the geology of the unsaturated zone. For example, extensive clay layers near the surface might reject recharge in one area and divert it laterally to another area. In addition, this would cause the existence of an extensive perched water table. Geologic samples in numerous areally distributed borings do not indicate the existence of an extensive continuous clay layer in the unsaturated zone of $\mathrm{A} / \mathrm{M}$ Area, even though the thin "Tan Clay" is encountered at a number of borings. In addition, there is no indication of an extensive perched water body. A temporary perched water body was indicated in one of the early borings around Lost Lake. This perched water body may have even been larger since 1982 when discharge from $M$ Area was increased. However, it is not believed that the existence of these relatively local and, in the absence of enhanced recharge, temporary perched water tables have a significant effect on the quantity or distribution of recharge to the permanent water table.

\subsubsection{Potentiometric Maps and Groundwater Velocity}

A water-table map constructed from water-level measurements made in July 1984 in monitoring wells installed mainly for the M-Area investigation is presented on Figure 5-3. (Water level data are given in Appendix F.) A total of 44 water levels in water table wells were used in the construction of the map. As can be seen from the map, a water-table high exists northeast of the M-Area basin. The water table is about 115 feet below the ground surface around the settling basin. The water table appears to reflect the increased water disposal at the $M-2$ outfall (Figure 5-2) and the seep area between Lost Lake and the settling basin.

The water-table gradients range from about 0.002 to $0.008 \mathrm{ft} / \mathrm{ft}$. The steeper gradients are in the direction of Tims $\mathrm{Branch}$ which is the nearest discharge point for the water table aquifer. Using the transmissivity of $570 \mathrm{ft} / \mathrm{d}$ ay calculated from the 30-day pump test (discussed in Section 5.3) and assuming the average saturated thickness of the Tertiary formations to be 110 feet, an average hydraulic conductivity of $5.18 \mathrm{ft} / \mathrm{day}$ $(570 \mathrm{ft} / \mathrm{day} \div 110 \mathrm{ft})$ is obtained. The average flow velocity at the water table in the Tertiary formations $c$ an be calculated using the expression $V=I K / E$

where:

$$
\begin{aligned}
& V=\text { Flow velocity (ft/day) } \\
& I=\text { Water table gradient (ft/ft) } \\
& E=\text { Effective porosity (dimensionless) } \\
& R=\text { Hydraulic conductivity (ft/day) }
\end{aligned}
$$


Using the average hydraulic conductivity of $5.18 \mathrm{ft} / \mathrm{day}$ and an assumed effective porosity of 0.20 (Section 5.3.4), the flow velocity would range from about 19 to $75 \mathrm{ft} / \mathrm{yr}$ for gradients of 0.002 to $0.008^{\circ} \mathrm{ft} / \mathrm{ft}$, respectively. This compares to estimated flow velocities of 20 to $25 \mathrm{ft} / \mathrm{yr}$ reported in the preliminary technical data summary, which was calculated using results of the 3-day pumping test and a gradient of about 0.003 which exists west of the basin. As mentioned, the higher gradients, and therefore probably the greater velocities, exist in the Tims Branch drainage.

A potentiometric map of the interval between elevations of 146 and 187 feet, or about 50 feet beneath the discontinuous "Green Clay" (within the Congaree Formation) is shown on Figure 5-4. This map shows a gentler gradient than the higher interval but has the same general pattern. A lobe apparently originates in the vicinity of the seep area, which was present but not as prominent in the water table map (Figure 5-3).

The potentiometric map of the interval between elevations 100 and 144 feet i.e., in the basal Tertiary sediments is shown in Figure 5-5. This interval was thought to be at the base of the Congaree Formation, but Paleocene fossils indicate that perhaps it is within the Ellenton Formation. The magnitude of the gradient is much gentler than the interval above. In addition, the direction of gradient has shifted more toward Upper Three Runs Creek, which should be the discharge point for water in this deep Tertiary zone. The water levels in this lower interval are below those in the intermediate zone (Figure 5-4) except for the last well to the south where the lower zone has a water level about 4 feet higher than the intermediate zone. This is approaching the area where the pressure surface of the "Tuscaloosa" becomes higher than that of the Congaree as shown on Figure 3-4.

The potentiometric map of the upper "Tuscaloosa" Formation, shown in Figure 5-6, indicates a swing back to a more southerly direction under the influence of drainage toward the Savannah River. The "nose" that is prominent in all of the Tertiary maps caused by drainage to Tims Branch, Upper Three Runs Creeks, and the Savannah River swamps is absent from the "Tuscaloosa" map which is only influenced by the Savannah River Valley. This gradient is consistent with the regional gradient (Christensen and Gordon, 1983, Figure 3-11).

The vertical gradients (the potential for water to move downward into underlying formations) can be measured by installing wells in different formations and at increasing depths from the water table. Measurements of water levels taken at different drill sites in the M-Area vicinity showed a continuing decrease in head with increasing depth, indicating that $M$ Area is located within a 
potential recharge zone of the "Tuscaloosa" Formation. "Tuscaloosa" monitoring wells were installed at several cluster locations (MSB-12, 23, 30, 31,34) for the purpose of obtaining additional information on the vertical head distribution with depth. The measured vertical hydraulic head distribution at two of these sites are presented on Figures 5-7 and 5-8. These measurements show a head difference of approximately 23 to 25 feet between the base of the Tertiary sediments and the underlying "Tuscaloosa." It is anticipated that this differential would decrease toward the Savannah River Valley and finally reverse.

Using an average vertical hydraulic conductivity for the Ellenton/"Tuscaloosa" clays of $0.0004 \mathrm{ft} / \mathrm{day}$, an average effective porosity of 0.07 (Table 5-1), a hydraulic head drop of 24 feet across the Ellenton (Figures 5-7 and 5-8), and an average clay thickness of 40 feet, a calculated vertical groundwater flow velocity of $1.3 \mathrm{ft} / \mathrm{yr}$ is obtained for flow across the Ellenton Formation.

What cannot be estimated from 1 aboratory measurements is the continuity of the clays and the amount of interconnection or communication that may occur across the Ellenton clays between the Tertiary sediments and the "Tuscaloosa" Formation. This can only be determined by pumping test. From the "Tuscaloosa" pumping test conducted by Geraghty \& Miller, Inc. (1983), an average leakance value of $1.1 \times 10^{-3} \mathrm{gpd} / \mathrm{ft}^{3}$ was calculated across the Ellenton Formation. If the Ellenton clay is $40 \mathrm{feet}$ in thickness, the leakance would translate to a hydraulic conductivity of $5.8 \times 10^{-3} \mathrm{ft} / \mathrm{day}$, which is about an order of magnitude higher than the laboratory values. Using this value, the vertical flow velocity should be about $19 \mathrm{ft} / \mathrm{yr}$ and water should traverse the Ellenton in about 2 years. This is probably a more applicable calculation than that using the laboratory values.

Using these same values, the leakage through the Ellenton Formation is about 10 gallons per square foot per year. The general A/M Area is about $5000 \mathrm{ft}$ by $5000 \mathrm{ft}$ making an area of 25 million $\mathrm{ft}^{2}$. Thus in this area about 250 million gallons per year may be recharging the "Tuscaloosa." Pumpage from the "Tuscaloosa" is about 650 million gallons per year from $A / M$ Area. The remainder is made up from lateral flow in the "Tuscaloosa"

The horizontal groundwater velocity in the Tuscaloosa is estimated at $170 \mathrm{ft} / \mathrm{yr}$ using a hydraulic conductivity of $40 \mathrm{ft} / \mathrm{day}$ (Section 5.3.5), a gradient of 0.0023 (Figure 5-6), and an effective porosity of 20 percent. The horizontal flux in the "Tuscaloosa" through a 5000 foot section of the A/M Area estimated to be 400 feet thick would be 500 million gallons per year. 


\subsubsection{Water-Level Fluctuations}

The horizontal gradients discussed in Section 5.2 .2 are generalized and only 5-foot contour intervals are used on Figures $5-3,5-4,5-5$, and 5-6. Due to fluctuations of several feet in several months, gradients may change but these are only applicable for a brief period of time. Using only the wells around the settling basin from April 1980 to August 1981, the water table gradient under the seepage basin shifted $45^{\circ}$ in a generally westward direction with a water level change of 1.6 feet. Such an alteration in gradients should be anticipated in other areas also.

Figures 5-9 through 5-13 show hydrographs of wells in clusters MSB 10, 11, 12, 17, and 34, respectively. The water-level fluctuations shown on these graphs are believed to be typical of the area (i.e., seasonal fluctuations). The longest record on these graphs is 2-1/2 years. A much longer record exists at well $\mathrm{S}-15$, which is about 1500 feet west of the settling basin (Figure 4-1) and screened about 25 feet below the water table. The total fluctuation in the water level in this well is a little over 10 feet as shown on Figure 5-14.

\subsubsection{Groundwater Discharge}

After flowing both vertically and laterally, groundwater is discharged naturally to springs and seeps in the nearby stream valleys. Water from the water table discharges to Tims Branch and to the swamps southwest of A/M Area. The water table also slopes towards and discharges to Hollow Creek. Water from the lower part of the Tertiary section flows toward and discharges to Upper Three Runs Creek and the swamps southwest of $A / M$ Area. Water from the "Tuscaloosa" discharges to the Savannah River Valley. Threedimensional numerical simulations are currently being pursued in order to quantify the flow, leakage, and discharge from each of these units.

\subsection{Hydraulic Properties}

The hydraulic properties of the geologic framework determine rate of groundwater movement, which will be of paramount importance during recovery operations. The properties of most importance are the transmissivity/permeability, porosity, storativity, and leakance.

\subsubsection{Laboratory Tests}

The results of laboratory tests performed on undisturbed samples taken from the clayey units of the Ellenton and upper 
"Tuscaloosa" Formations are presented on Table 5-1. A total of five samples were shipped to Law Engineering Testing Company's soils laboratory in At lanta, GA for analysis. Parameters measured included unit weight, moisture content, void ratio, specific gravity, porosity (total and effective), permeability (vertical and horizontal), and grain size distribution. Effective porosity and permeability (hydraulic conductivity) are the most important in evaluating the ability of geologic materials to transmit water. Effective porosity is a measure of the amount of interconnected pore space available for fluid transmission, while hydraulic conductivity is a measure of the ease with which water can be transmitted through a porous material. The results of the vertical permeability measurements of the samples ranged from $4.0 \times 10^{-7}$ to $5.2 \times 10^{-9} \mathrm{~cm} / \mathrm{sec}\left(1.1 \times 10^{-3}\right.$ to $\left.1.1 \times 10^{-5} \mathrm{ft} / \mathrm{day}\right)$, and the horizontal permeability measurements ranged from $5.7 \times 10^{-7}$ to 1.1 $\times 10^{-8} \mathrm{~cm} / \mathrm{sec}\left(1.6 \times 10^{-3}\right.$ to $\left.3.1 \times 10^{-5} \mathrm{ft} / \mathrm{day}\right)$ indicating that the clays transmit water extremely slowly.

The effective porosities determined for these samples are also low, ranging from 0.024 to 0.137 (dimensionless). These compare to average effective porosities of 0.20 and 0.30 generally used for the Tertiary and "Tuscaloosa" sands, respectively.

\subsubsection{Recovery Tests On Observation Wells}

Table 5-2 gives the results of rests on individual wells where the recovery of the water level is measured after pumping the well for some period of time. Calculation of transmissivity from these tests is extremely crude because most of the wells have only 10 foot screens, and thus flow to the screen is semi-spherical instead of two-dimensional as assumed in the analysis. Since all the water level measurements are in the same well from which the withdrawal took place, they are also influenced by the development of the well. Thus low apparent transmissivities may be due to inadequate development. Nevertheless the values obtained may be useful because they are areally distributed and do represent an approximate value for transmissivity.

\subsubsection{Water Injection Test on Mell MPT-1}

The 72-hour pumping test reported in the Preliminary Technical Dat a Summary, DPSTD-82-69, affected observation wells at different depths (Figure 5-15) in an unpredictable manner. Specifically observation well MSB-11F, a water table well 30 feet from the pumping well, showed no drawdown at all. Because there was difficulty in developing well MPT-1, there was speculation that perhaps parts of the screened zone were selectively developed, such that one or a few restricted zones might be yielding all the water. In 
order to determine how uniformly the screen zone was developed, $60 \mathrm{gpm}$ was injected into the well while making velocity measurements with a vertical, cable hung, vane-type meter. The actual measurements are in revolutions per second of the vanes. The results of this test are shown on Figure 5-16. Measurements were made in the casing at depths of $110,115,120$, and 125 feet, and these averaged 1.5 revolution per second as shown by the vertical bar on Figure 5-16. This average is taken to represent 100 percent of the flow down the casing. From the measurements shown at various depths within the screen zone on Figure 5-16, an injection profile $c$ an be calculated, and this is given in Table 5-3. From this profile, it is concluded that although a zone near the top of the screen accepts 33 percent of the water injected, the acceptance is rather uniformly distributed throughout the length of the screen. If the yield profile of the well is the same as the injection profile, the cause for the unpredictable drawdown in the observation wells during the pumping test must be sought elsewhere than in the selective development of the screened zone.

\subsubsection{0-Day Pumping Test in Tertiary Sediments}

After completion of the M-Area Production Test Nell (MPT-1) in June 1982, an eight-hour step-drawdown and 72-hour pumping test were performed. The results of these tests, which are discussed in the Preliminary Technical Data Summary (DPSTD-82-69), indicate an adjusted transmissivity of $1100 \mathrm{gpd} / \mathrm{ft}$ and a coefficient of storage of 0.14 . Using these values it was estimated that one recovery well pumping at a rate of $30 \mathrm{gpm}$ ( $\mathrm{gallons}$ per minute) could influence an area of radius 400 feet.

Between October 18 and November 17, 1982, a 30-day continuous pumping test was conducted utilizing MPT-1 (Bledsoe, 1983). The objectives of this test were: 1) to attempt to physically develop the cone of depression at the water table for comparison with the calculated rate of growth from the 72-hour test, and 2) to obtain additional chemical data and establish a better basis for organic concentration in the feed stream to the reference groundwater treatment process (air stripping). A schematic illustration of the screen zones of the pumping and observation wells is given in Figure 5-15.

As with the 72-hour test, the 30-day test was conducted at a constant discharge rate of $30 \mathrm{gpm}$. A total of $1.25 \mathrm{million}$ gallons of water was removed from the aquifer during the test.

The drawdown in the pumping well during the 30-day test was similar in shape to that in the 72-hour test except that the drawdown was less (Figure 5-17). The drawdown at the end of the 30-day test was 7 to 9 feet less than that for the 72-hour test, even 
though both tests were conducted at $30 \mathrm{gpm}$. The maximum drawdown in the 72-hour test was 35 feet and that in the 30-day test was 27 feet. Observation wells MSB-11B and $11 \mathrm{C}$ were the most responsive (Figure 5-18). The drawdown in MSB-11B was 2.02 feet at the end of the 72-hour test and 2.60 feet at the end of the 30-day test. The comparison of drawdowns in the observation wells is what one would expect, i.e., the greater drawdown from the longer test. Coupling of the information from the observation wells and the pumping well indicate that the pumping well underwent some additional development between the two tests. The only event to have occurred at the MPT-1 between the two tests was the injectivity test. This test was described in Section 5.3.3. As can be seen from the two drawdown curves (Figure 5-17), the results closely parallel each other except for the observed drawdowns.

As with the 72-hour test, data from observation well MSB-11C were more amenable to analysis than data from the other observation wells and thus were used for analysis of the 30-day test. The test data for MSB-11C were plotted on log-log paper (Figure 5-19) for analysis using Boulton's (1963) method for unconfined aquifers with vertical movement. The type curve used in the analys is is superimposed on the MSB-11C data points on Figure 5-19. The results of curve matching by SRL yield a calculated transmissivity value of $4200 \mathrm{gpd} / \mathrm{ft}\left(570 \mathrm{ft}^{2} / \mathrm{day}\right)$ and a storage coefficient of 0.27 . Adjusting the calculated values to fit the observed field data for MSB-11C after 30 days of pumping produces a transmissivity of $4200 \mathrm{gpd} / \mathrm{ft}$ and a storage coefficient of 0.20 . This value for transmissivity is higher than most of those given on Table 5-2 for short term tests on monitoring wells for the reasons given in Section 5.3.2.

From the 72-hour data it was estimated that a cone of influence with a radius of approximately 400 feet could be established after pumping continuously for a period of 30 days at $30 \mathrm{gpm}$ with a predicted drawdown of the water table of approximately 0.5 feet. Using the hydraulic parameters calculated from the 30-day test, the maximum calculated radius of the cone of depression would be approximately 350 feet.

Raw field data from the 30-day pumping test were also independently analyzed and evaluated by a Geraghty \& Miller hydrogeologist. The results of the Geraghty \& Miller analysis indicated a transmissivity of approximately $4300 \mathrm{gpd} / \mathrm{ft}$ with a storage coefficient of 0.22 which is in good agreement with the results calculated by SRL.

No water level declines that could be attributed to the pumping well were observed at observation wells more distant than the MSB-11 cluster ( 30 to 80 feet from the pumping well). 


\subsection{5 "Tuscaloosa" Aquifer Pumping Test}

In order to determine the hydraulic properties of the "Tuscaloosa" aquifer system in M-Area vicinity, an aquifer pumping test was conducted by Geraghty \& Miller, Inc. (1983) on April 2324, 1983. Production Well 905-20A was used as the pumping well and water levels were measured in seven nearby wells including three other production wells which were shut down for the test. Two of the wells are screened in the Tertiary sediments overlying the Ellenton Formation; the other wells are all screened in the "Tuscaloosa" Formation. The locations of the wells utilized in the test are shown in Figure 5-20.

The pumping test included a three-stage step-drawdown test followed by a 33-hour continuous pumping test. The purpose of the step-drawdown test was to determine the efficiency of the pumping well (905-20A). The results of the step-drawdown test, tabulated in Table 5-4, indicate that Well $905-20 \mathrm{~A}$ is relatively efficient. A plot of water level vs. time for the pumping well throughout both the step-drawdown test and the continuous pumping test is shown on Figure 5-21. During the 33-hour test, Well 905-20A was pumped at a constant discharge rate of $1,035 \mathrm{gpm}$ (gallons per minute). Waterlevel measurements were taken in the other three "Tuscaloosa" production wells and the four monitoring wells, as well as the pumping well, during the pumping test and for a period of four hours during the recovery period after the pump was shut down. All water-level data were ad justed to eliminate the effects of changes in atmospheric pressure and the preceeding step-drawdown test prior to dat a analyses.

Geraghty \& Miller (1983) analyzed the adjusted water-level data using both Hantush-Jacob (1955) leaky artesian-type curves and the Cooper-Jacob (1946) method. Data from Wells 905-82A, 905-31A, and 905-53A were used to determine transmissivity, storage coefficient, and leakance values for the aquifer. Recovery data from the pumped well $(905-20 \mathrm{~A})$ were also analyzed to determine transmissivity by the Cooper-Jacob method. Results of the various analyses are presented on Table 5-5. On the basis of these analyses, Geraghty \& Miller believes the representative transmissivity, storage coefficient, and leakance values for the "Tuscaloosa" Formation in the M-Area vicinity to be $79,000 \mathrm{gpd} / \mathrm{ft}, 4.2 \times 10^{-4}$, and $1.1 \times 10^{-3} \mathrm{gpd} / \mathrm{ft}^{3}$, respectively. For comparison, siple (1967) reports a transmissivity of $90,000 \mathrm{gpd} / \mathrm{ft}$ and a storage coefficient of $3 \times 10^{-4}$ for a test conducted in January 1952 using 905-20A as the pumping well and $905-31 \mathrm{~A}$ as the observation well.

The screened zone of this well extends from a depth of 417 feet to 675 feet making a screened interval of 258 feet. Using this as the aquifer thickness, the hydraulic conductivity would be $40 \mathrm{ft} / \mathrm{day}$. 
"Tuscaloosa" observation wells MSB-23A and MSB-30A located at distances of approximately 1500 and 3000 feet, respectively, from the pumped well (Figure 5-20) were affected only slightly by the pumping and were therefore not analyzed. Hydrographs of these wells are shown on Figure 5-22. Water levels in wells screened at the water table (MSB-23) and within the mid-Tertiary (MSB-23B) also located at a distance of approximately 1500 feet from the pumped well (Figure 5-20) did not reflect the effects of pumping during this test. Hydrographs of these two wells are shown on Figure 5-23. 
References For Chapter 5

Bledsoe, H. W., 1983. 30-Day Continuous Pumping Test, M-Area Production Test Well (MPTW-1), October 18 - November 17, 1982, DPST-83-286, E. I. du Pont de Nemours and Company, Aiken, SC.

Boulton, N. S., 1963. Analysis of Data from Nonequilibrium Pumping Tests Allowing for Delayed Yield from Storage, Institute of Civil Engineers Proceedings (London) V. 26, PP. 469-482.

Cahill, J. M., 1982. Hydrology of the Low-Level Radioactive-Solid Waste Burial Site and Vicinity Near Barnwell, South Carolina, U.S. Geological Survey Open File Report 82-863.

Christensen, E. J. and D. E. Gordon, 1983. Technical Summary of Groundwater Quality Protection Program at Savannah River Plant, Vo1. 1, DPST-83-829, E. I. du Pont de Nemours and Company, Savannah River Laboratory, Aiken, SC.

Cooper, H. H. and C. E. Jacob, 1946. A Generalized Graphical Method for Evaluating Constants and Summarizing Well-field History, American Geophysical Union Transactions, V. 27, No. 4, pp. 526-534.

Geraghty \& Miller, Inc., 1983. Tuscaloosa Aquifer Pumping Test, M-Area, Savannah River Plant, April 1983, Geraghty \& Miller, Inc.

Geraghty \& Miller, Inc., 1984. Basic Data Report, Drilling and Installation at Test Sites MSB-12 and MSB-34, Geraghty \& Miller, Inc.

Gordon, D. E., 1982. Preliminary Technical Data Summary, M-Area Groundwater Cleanup Facility, DPSTD-82-69, E. I. Du Pont de Nemours and Company, Savannah River Laboratory, Aiken, SC.

Hantush, M. S. and C. E. Jacob, 1955. Nonsteady Radial Flow in an Infinite Leaky Aquifer, American Geophysical Union Transactions, v. 36 , No. 1, pp. 95-100.

Hubbard, J. E., 1984. Water Budget for SRP Burial Ground Area, DPST-83-742, E. I. du Pont de Nemours and Company, Savannah River Laboratory, Aiken, SC. 
Martin, H. L:, 1984. Personal Communication.

Parizek, R. R. and R. W. Root, Jr., 1984. Progress Toward Development of a Groundwater Velocity Model for the Radioactive Waste Management Facility Savannah River Plant, South Carolina, Quarterly Report July 15, 1984, The Pennsylvania State University, University Park, PA.

Siple, G. E., 1967. Geology and Ground Dater of the Savannah River Plant and Vicinity, South Carolina, U.S. Geological Survey Water-Supply Paper 1841 . 
TABLE 5-1

Summary of Soil Test Results

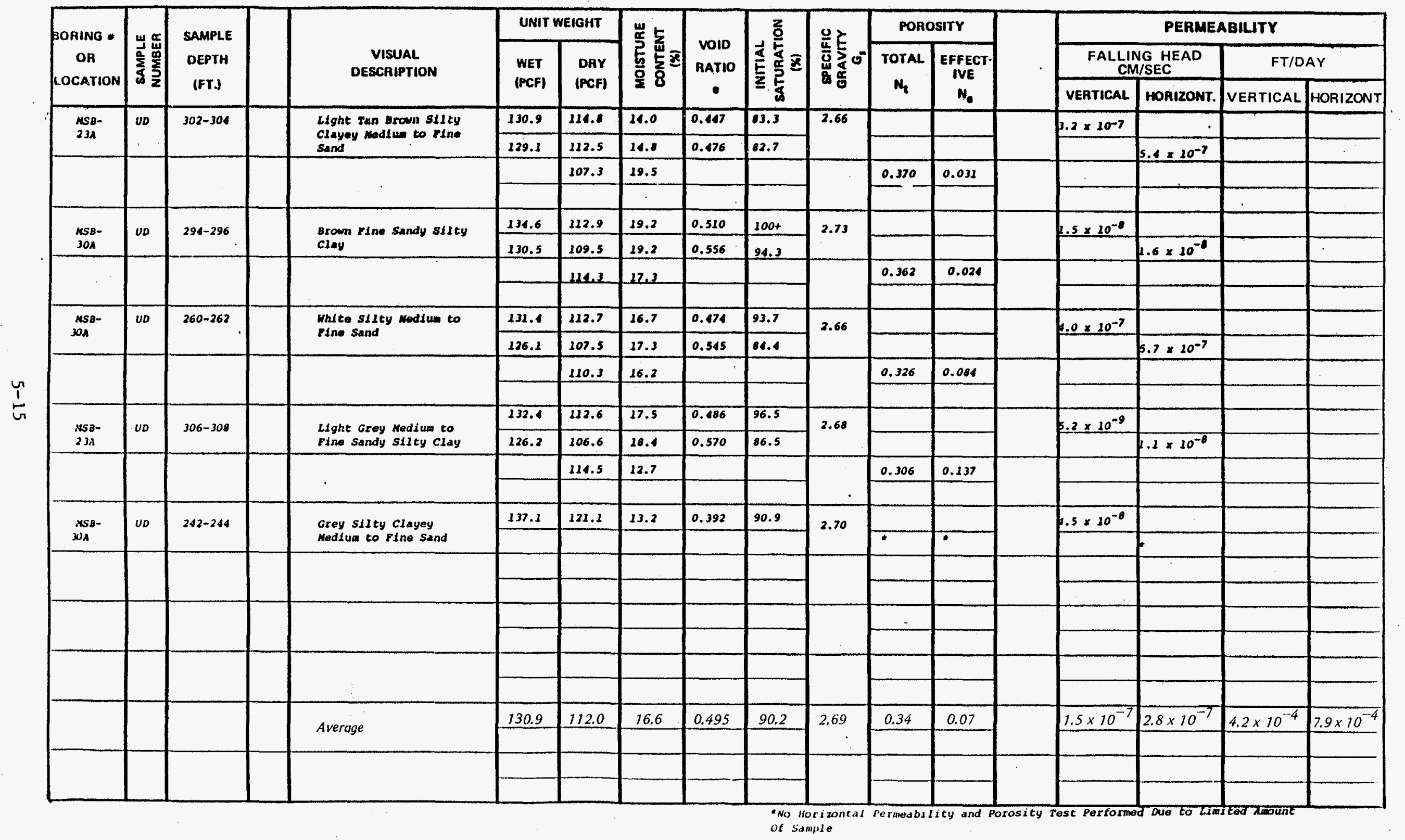


TABLE 5-2

Results of Recovery Tests on Individual Observation Wells in $M$ Area

\begin{tabular}{|c|c|c|c|c|}
\hline \multirow{2}{*}{$\begin{array}{l}\text { Test } \\
\text { No. } \\
\end{array}$} & \multirow[b]{2}{*}{ Well No. } & \multicolumn{2}{|c|}{$\begin{array}{l}\text { Screen Zone } \\
\text { Elevation ( } f t)\end{array}$} & \multirow{2}{*}{$\begin{array}{l}\text { Transmissivity } \\
\text { (gpd/ft) }\end{array}$} \\
\hline & & Top & Bottom & \\
\hline 1 & $M S B-9 C$ & 241 & 221 & 1900 \\
\hline 2 & $M S B-10 A$ & 123 & 118 & 4085 \\
\hline 3 & $M S B-10 B$ & 155 & 150 & 35 \\
\hline 4 & MSB-10C & 210 & 205 & 270 \\
\hline 5 & $M S B-11 A$ & 135 & 130 & 70 \\
\hline 6 & $M S B-11 B$ & 165 & 150 & 140 \\
\hline 7 & $M S B-11 C$ & 182 & 177 & 130 \\
\hline 8 & $M S B-11 D$ & 208 & 203 & 1180 \\
\hline 9 & $M S B-12 B$ & 151 & 156 & 85 \\
\hline 10 & $M S B-12 C$ & 183 & 178 & 2435 \\
\hline 11 & MSB-13A & 135 & 130 & 2475 \\
\hline 12 & $M S B-14 A$ & 164 & 144 & 2400 \\
\hline 13 & $M S B-14 B$ & 194 & 189 & 180 \\
\hline 14 & $M S B-14 C$ & 244 & 224 & 185 \\
\hline 15 & $M S B-15 A$ & 167 & 162 & 135 \\
\hline 16 & MSB-16A & 166 & 161 & 1350 \\
\hline 17 & $M S B-17 A$ & 160 & 155 & 2160 \\
\hline 18 & $M S B-17 B$ & 190 & 185 & 430 \\
\hline 19 & $M S B-18 A$ & 162 & 157 & 130 \\
\hline 20 & $M S B-18 B$ & 197 & 192 & 4980 \\
\hline 21 & $M S B-18 C$ & 227 & 207 & 180 \\
\hline 22 & $M S B-19 A$ & 120 & 115 & 16,500 \\
\hline 23 & MSB-1 9C & 218 & 198 & 1725 \\
\hline 24 & $\mathrm{MSB}-20 \mathrm{~A}$ & 161 & 156 & 260 \\
\hline 25 & $M S B-21 C$ & 232 & 212 & 3800 \\
\hline 26 & $A C-3 A$ & 153 & 148 & 30 \\
\hline
\end{tabular}


TABLE 5-3

Injection Profile for MPT-1

Depth of Zone from

Ground Surface ( $f t$ )

125-130

130-140

140-150

150-160

160-170

$170-180$

$180-190^{\circ}$
Percent of Total Flow

Passing Out of Zone

33.3

6.7

13.3

20

10

16.7

0

TABLE 5-4

Results from the Step-Drawdown Test on Production Well 905-20A Screened in the "Tuscaloosa" Formation

\begin{tabular}{|c|c|c|c|}
\hline $\begin{array}{l}\text { Step } \\
\text { Number }\end{array}$ & $\begin{array}{l}\text { Pumping } \\
\text { Rate (g pm) }\end{array}$ & $\begin{array}{l}\text { Total } \\
\text { Drawdown (ft) }\end{array}$ & $\begin{array}{l}\text { Specific } \\
\text { Capacity } \\
\text { (gpm/ft) }\end{array}$ \\
\hline 1 & 350 & 15.03 & 23.29 \\
\hline 2 & 690 & 29.61 & 23.30 \\
\hline 3 & 1035 & 42.70 & 24.24 \\
\hline
\end{tabular}




\section{TABLE 5-5}

Summary of Hydraulic Properties of the "Tuscaloosa" Aquifer as Determined from a Pumping Test on Production Wel1 905-20A

\begin{tabular}{|c|c|c|c|c|}
\hline $\begin{array}{l}\text { Well } \\
\text { Number }\end{array}$ & $\begin{array}{l}\text { Transmissivity } \\
(\mathrm{gpd} / \mathrm{ft})\end{array}$ & $\begin{array}{l}\text { Storage } \\
\text { Coefficient }\end{array}$ & $\begin{array}{l}\text { Leakance } \\
\left(\mathrm{gpd} / \mathrm{ft}^{3}\right) \\
\end{array}$ & Method Used \\
\hline $905-20 A$ & 77,850 & & & $\begin{array}{l}\text { Cooper-Jacob } \\
\text { (recovery) }\end{array}$ \\
\hline \multirow[t]{3}{*}{$905-82 \mathrm{~A}$} & 79,090 & $4.3 \times 10^{-4}$ & $1.16 \times 10^{-3}$ & $\begin{array}{l}\text { Hantush-Jacob } \\
\text { (drawdown) }\end{array}$ \\
\hline & 79,090 & $3.7 \times 10^{-4}$ & & $\begin{array}{l}\text { Hant ush-Jacob } \\
\text { (recovery) }\end{array}$ \\
\hline & 79,970 & $4.3 \times 10^{-4}$ & & $\begin{array}{l}\text { Cooper-Jacob } \\
\text { (drawdown) }\end{array}$ \\
\hline \multirow[t]{3}{*}{$905-31 A$} & 95,520 & $4.7 \times 10^{-4}$ & $1.09 \times 10^{-3}$ & $\begin{array}{l}\text { Hantush-Jacob } \\
\text { (drawdown) }\end{array}$ \\
\hline & 79,050 & $4.0 \times 10^{-4}$ & & $\begin{array}{l}\text { Hantush-Jacob } \\
\text { (recovery) }\end{array}$ \\
\hline & 85,390 & $4.2 \times 10^{-4}$ & & $\begin{array}{l}\text { Cooper-Jacob } \\
\text { (drawdown) }\end{array}$ \\
\hline \multirow[t]{3}{*}{$905-53 A$} & 84,690 & $8.2 \times 10^{-4}$ & $3.25 \times 10^{-3}$ & $\begin{array}{l}\text { Hantush-Jacob } \\
\text { (drawdown) }\end{array}$ \\
\hline & 79,050 & $8.7 \times 10^{-4}$ & & $\begin{array}{l}\text { Hantush-Jacob } \\
\text { (recovery) }\end{array}$ \\
\hline & 105,910 & $6.8 \times 10^{-4}$ & & $\begin{array}{l}\text { Cooper-Jacob } \\
\text { (drawdown) }\end{array}$ \\
\hline
\end{tabular}




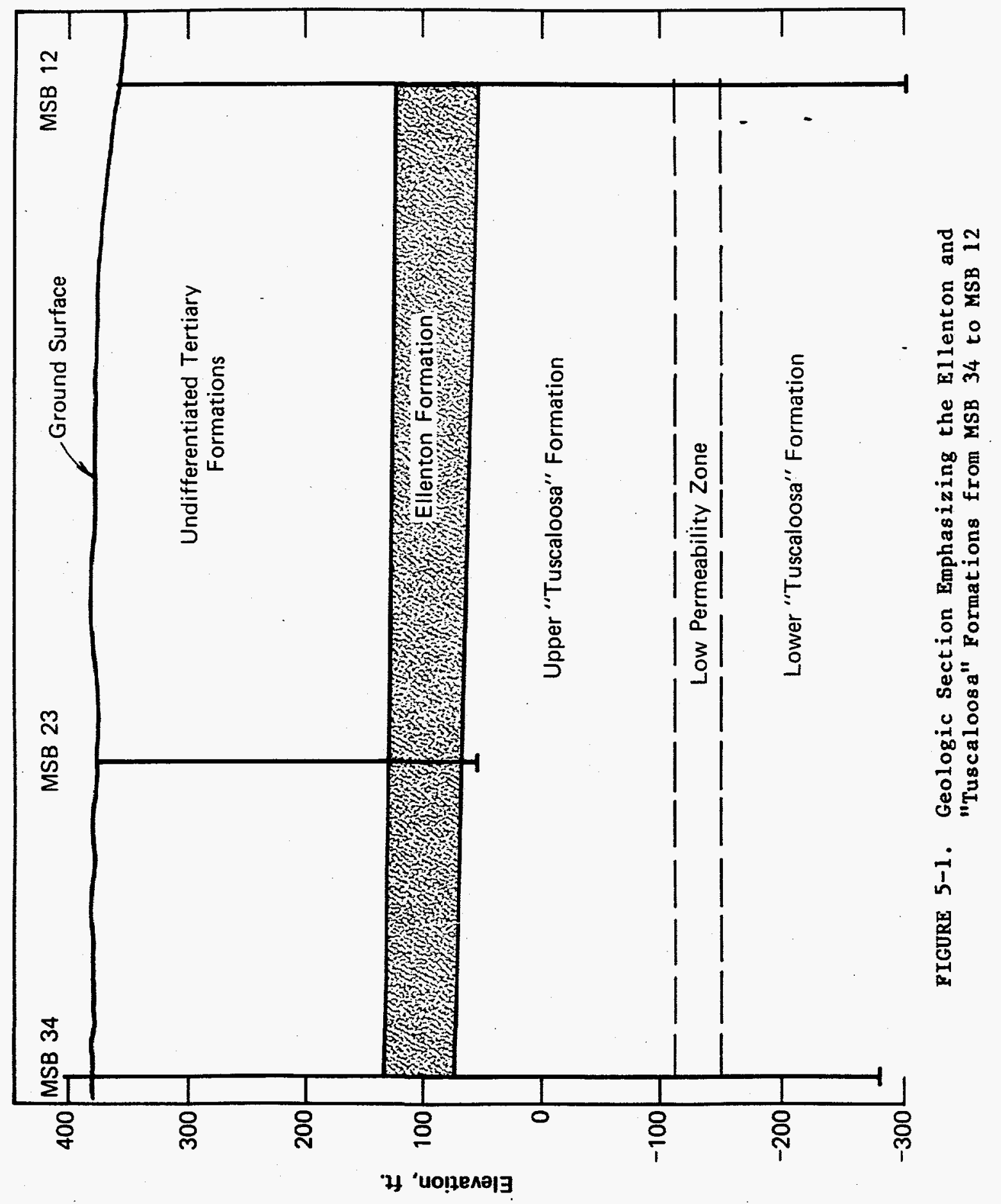




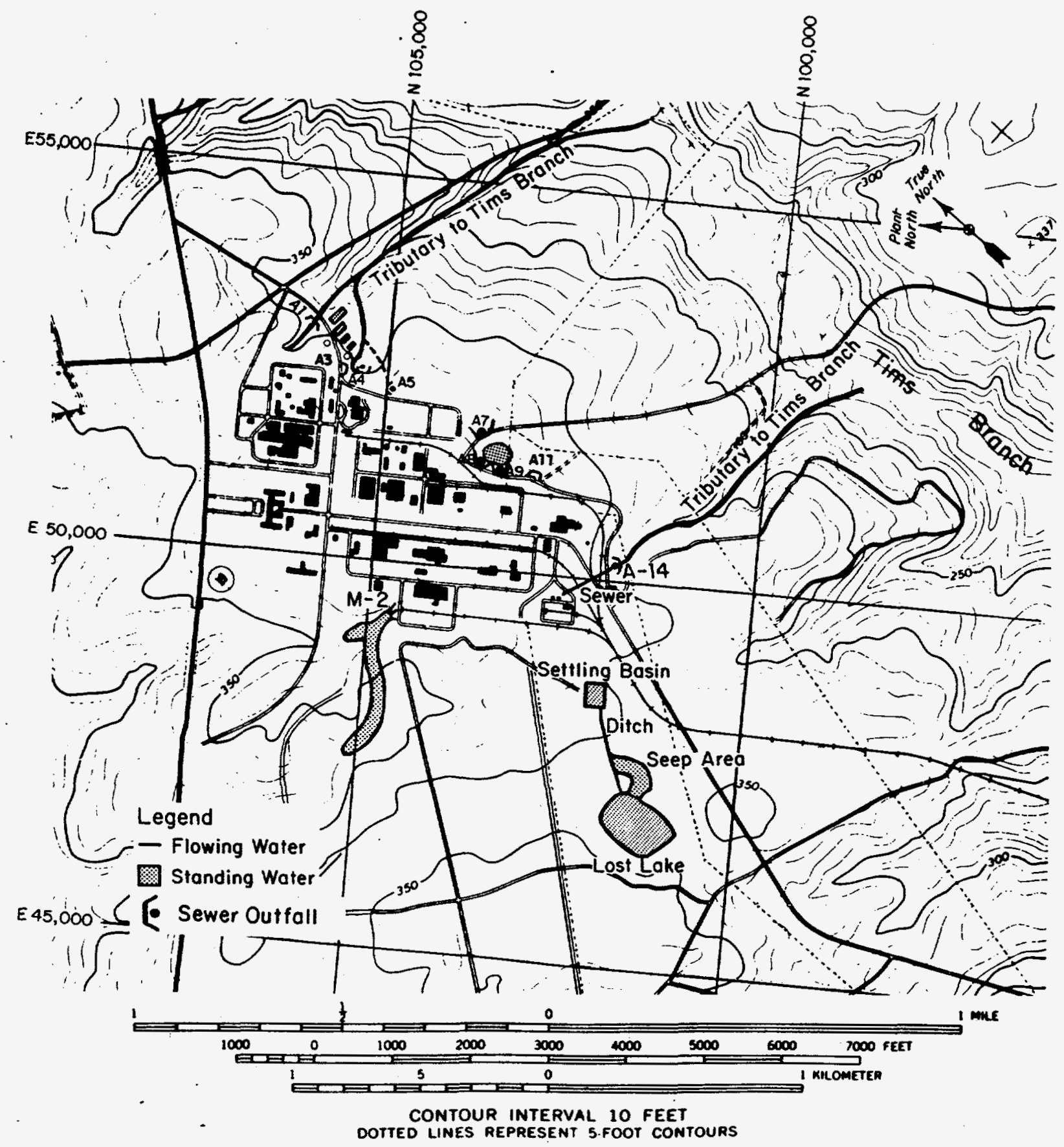

FIGURE 5-2. Location of Water Disposal Areas (Summer 1984) 


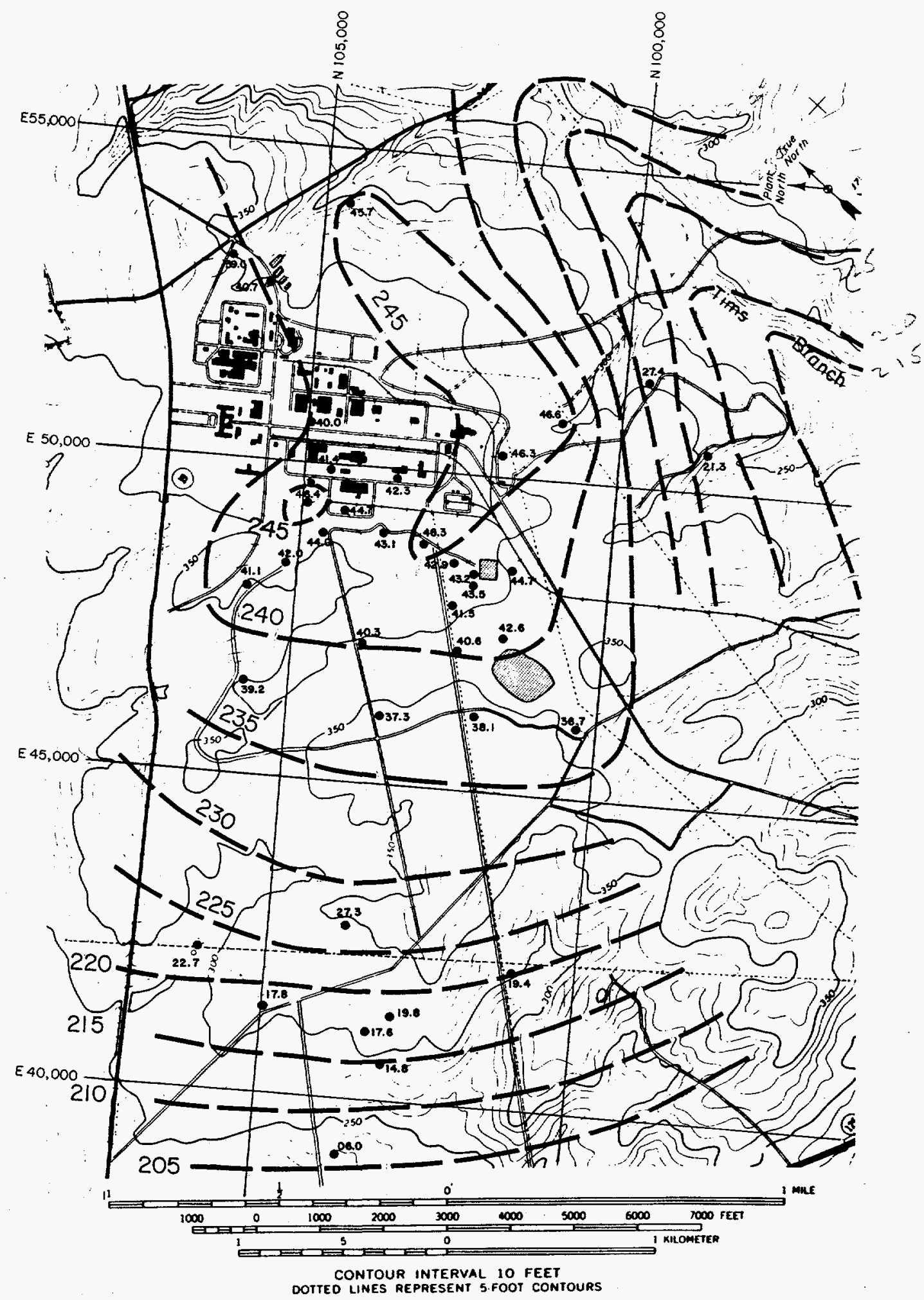

FIGURE 5-3. Water Table Elevation Map for Spring 1984 (Values are in feet. For the data point the first digit, i.e., 200 , is omitted to avoid crowding of the numbers.) 


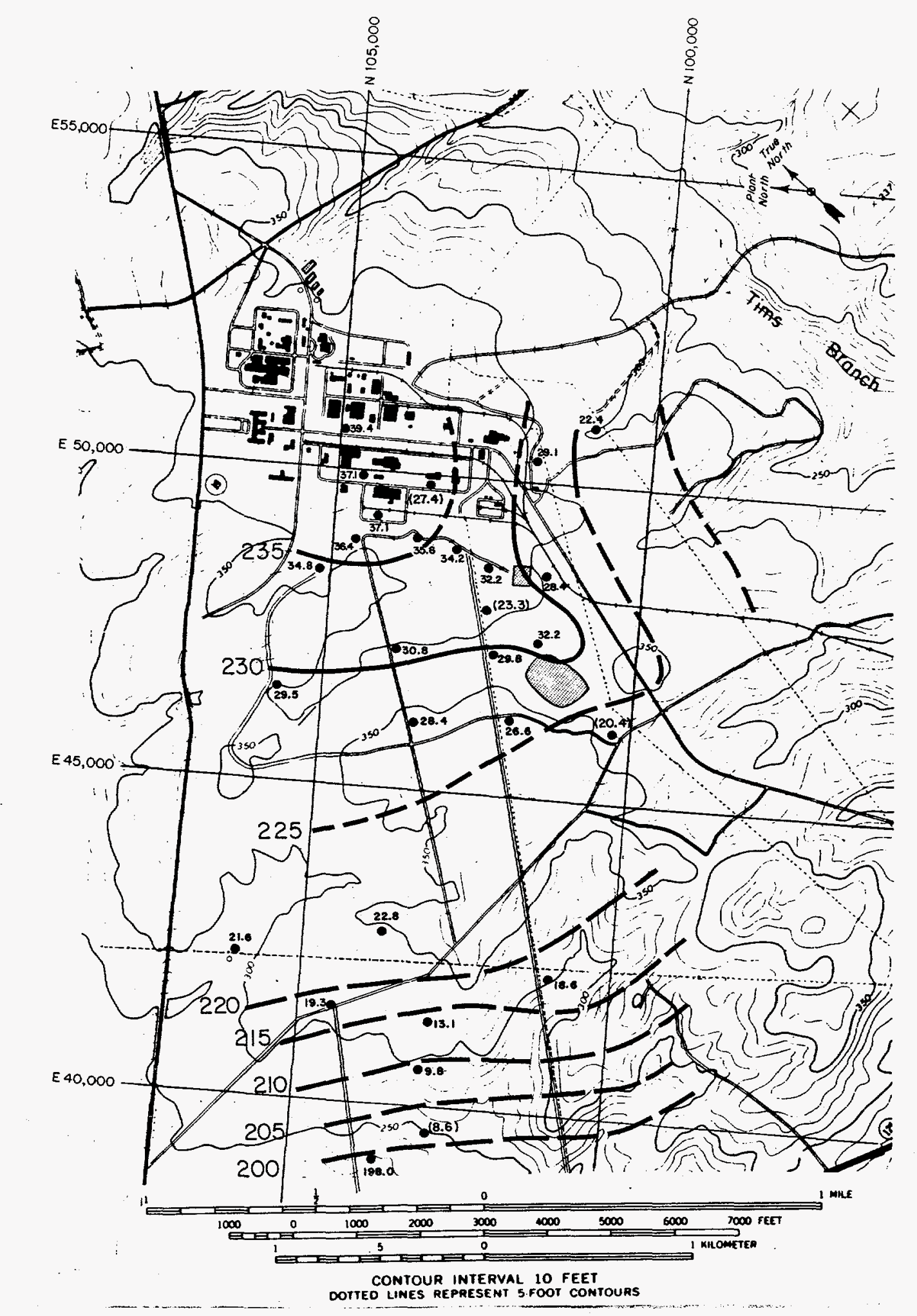

FIGURB 5-4. Potentiometric Map of the Blevation Interval where the Top of Screen is Between 146 and $187 \mathrm{ft}$, i.e., 50 ft Below the "Green Clay", for April-June 1984

(Parentheses indicate the water level in a well screened within the elevation interval that is not used in drawing contours. Anomalous water levels within this elevation interval could be caused by local clay layers causing greater head loss for water to enter sand layers. All water levels not used in contouring are lower than those in surrounding wells. None are too high.) 


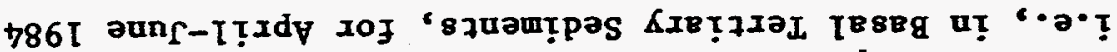

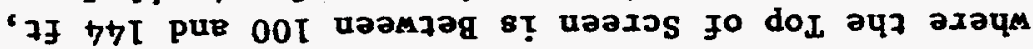

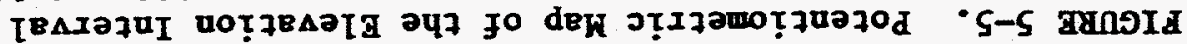

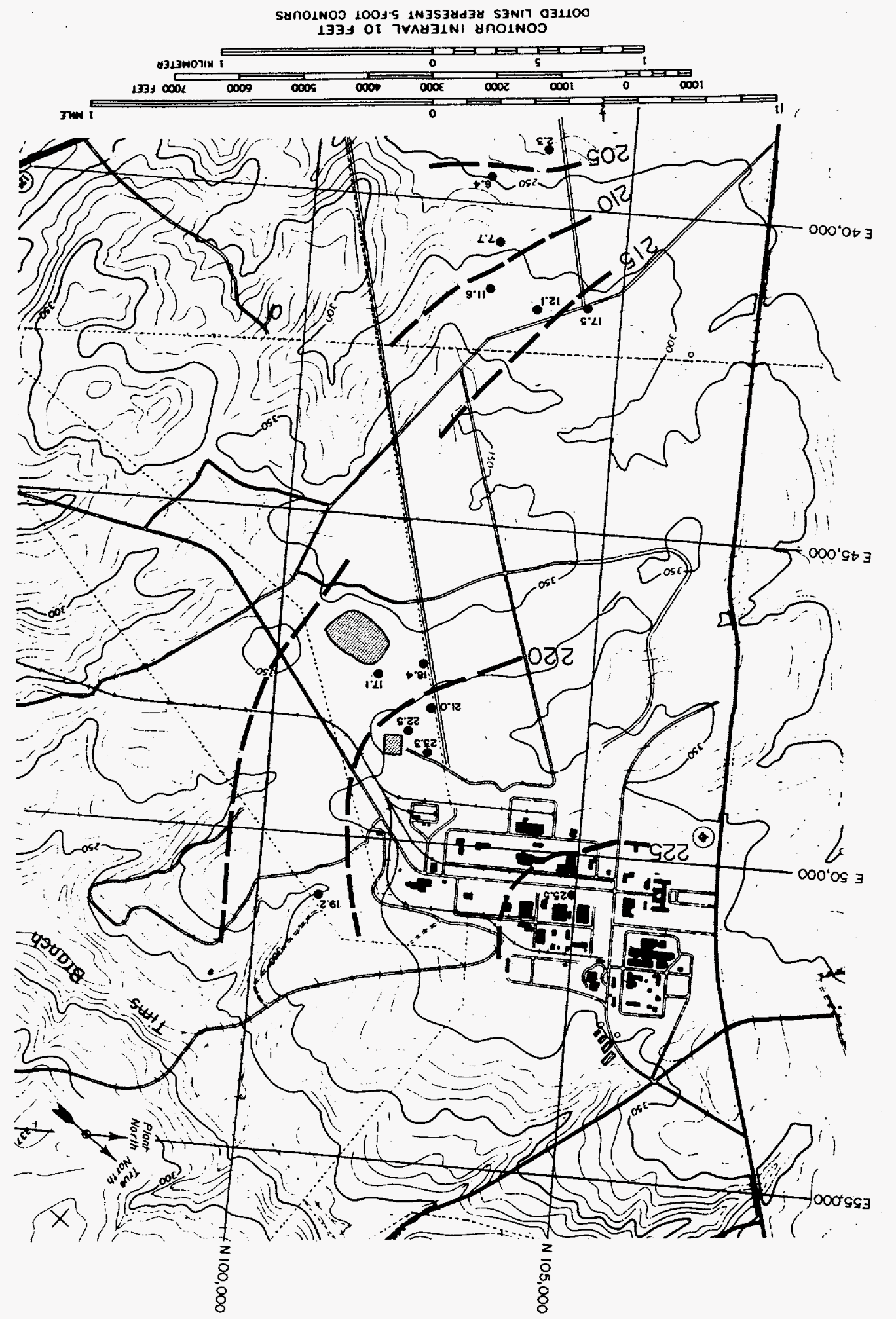




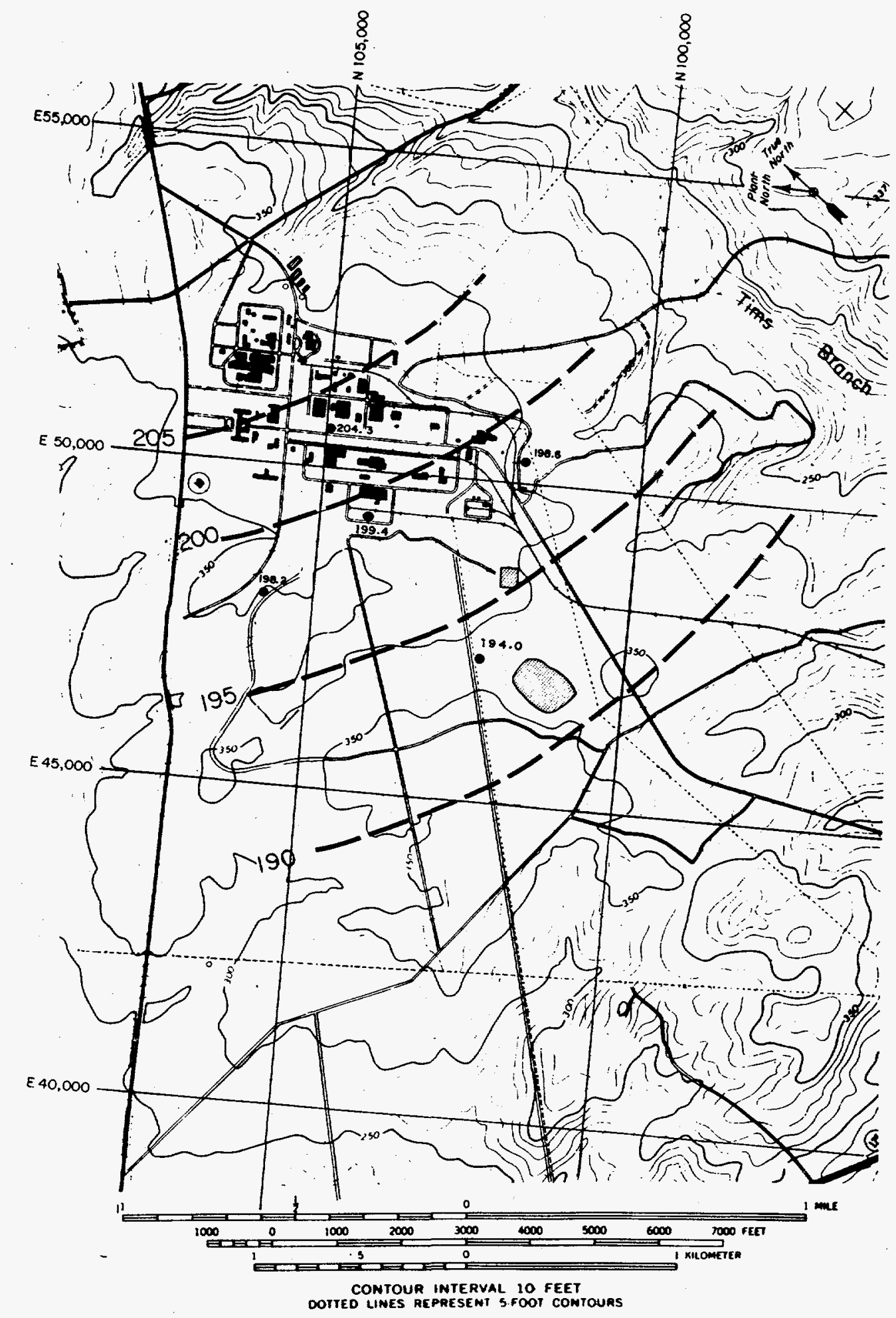

FIGORB 5-6. Potentiometric Map of the Blevation Interval

where the Top of the Screen is Between 14 and $76 \mathrm{ft}$, i.e., Opper "Tuscaloosa" Formation, for May 1984 


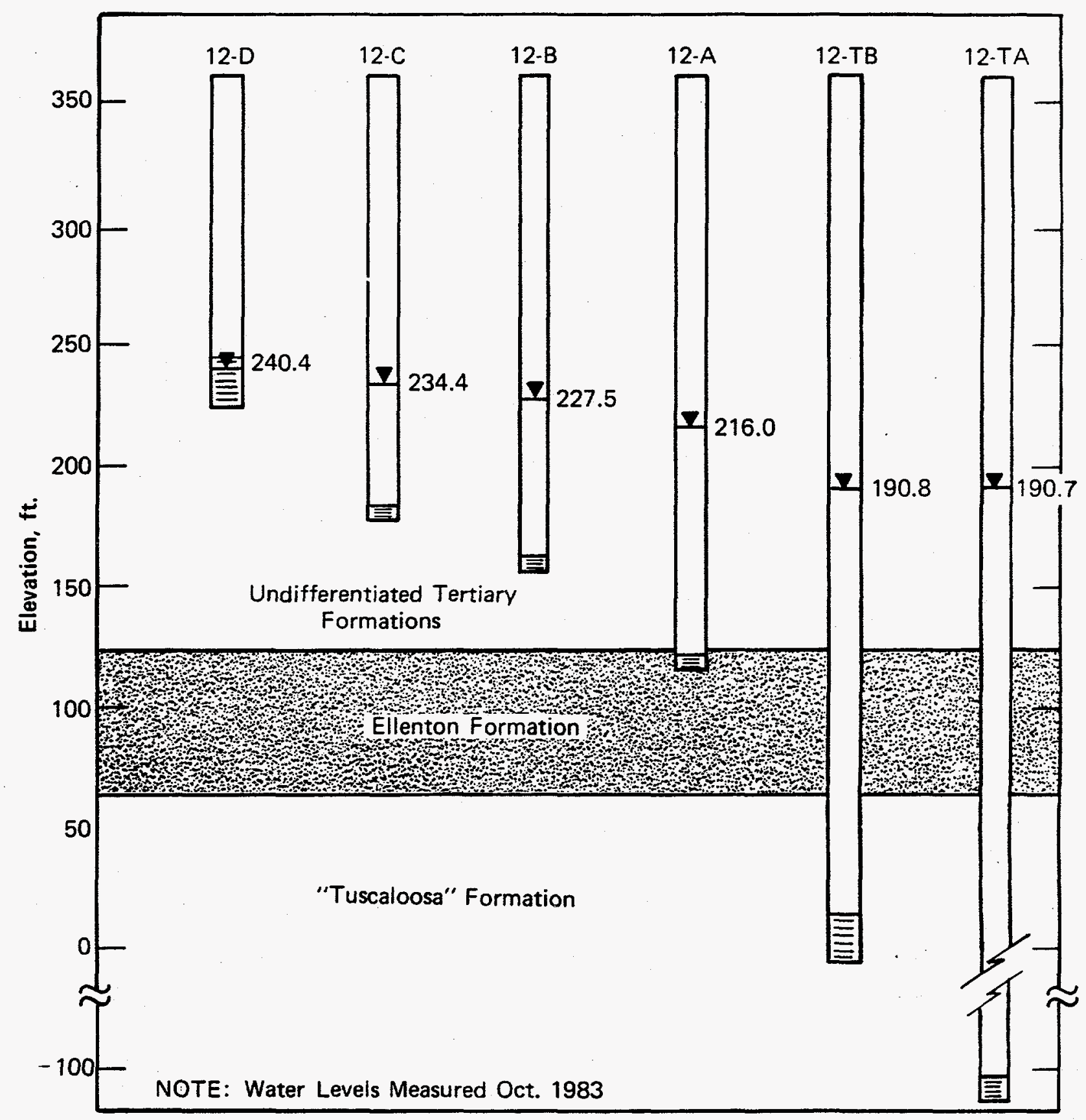

FIGURB 5-7. Water Levels at Selected Depths at MSB-12 


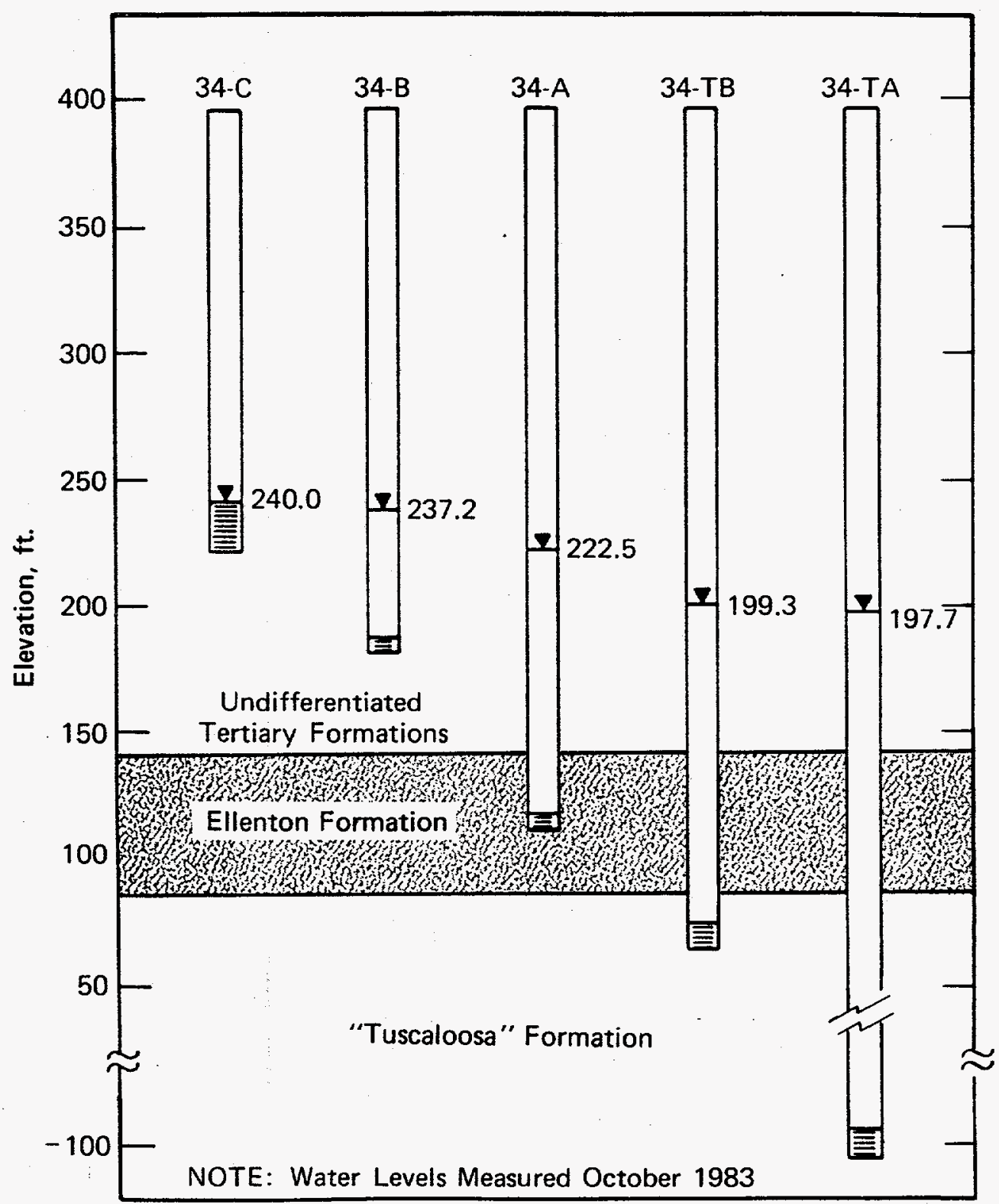

FIGURE 5-8. Water Levels at Selected Depths at MSB-34 


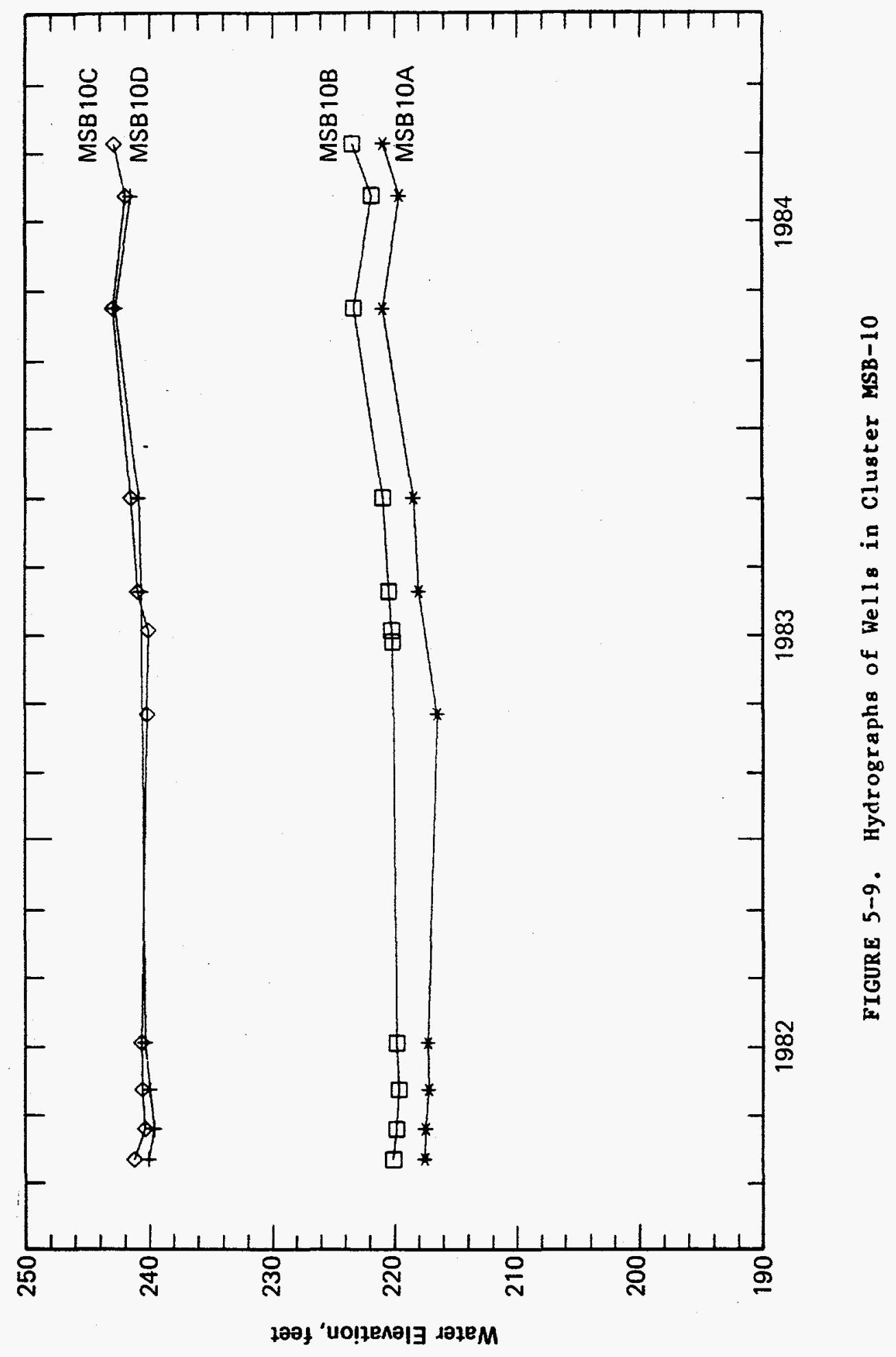

$5-27$ 


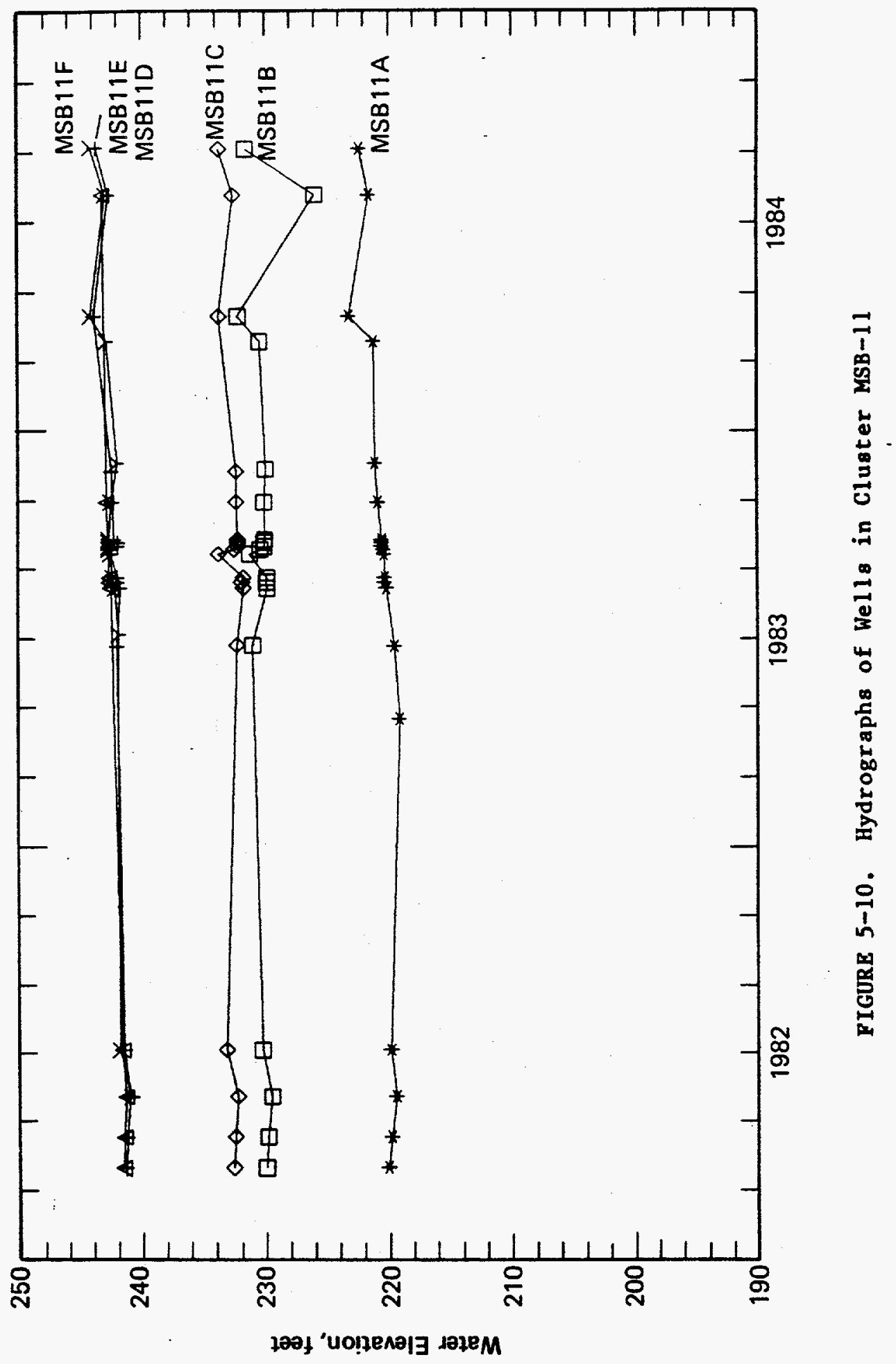




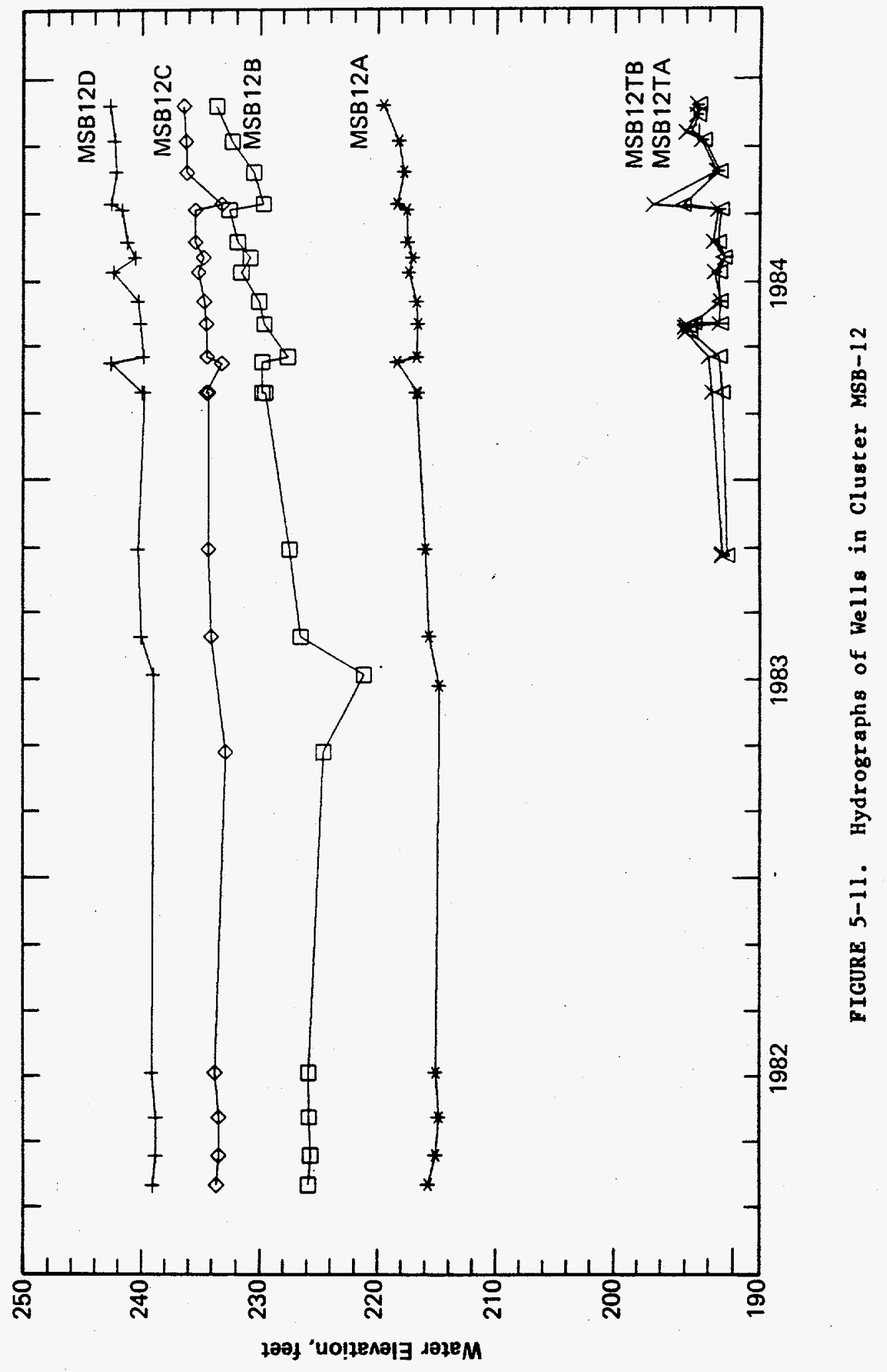




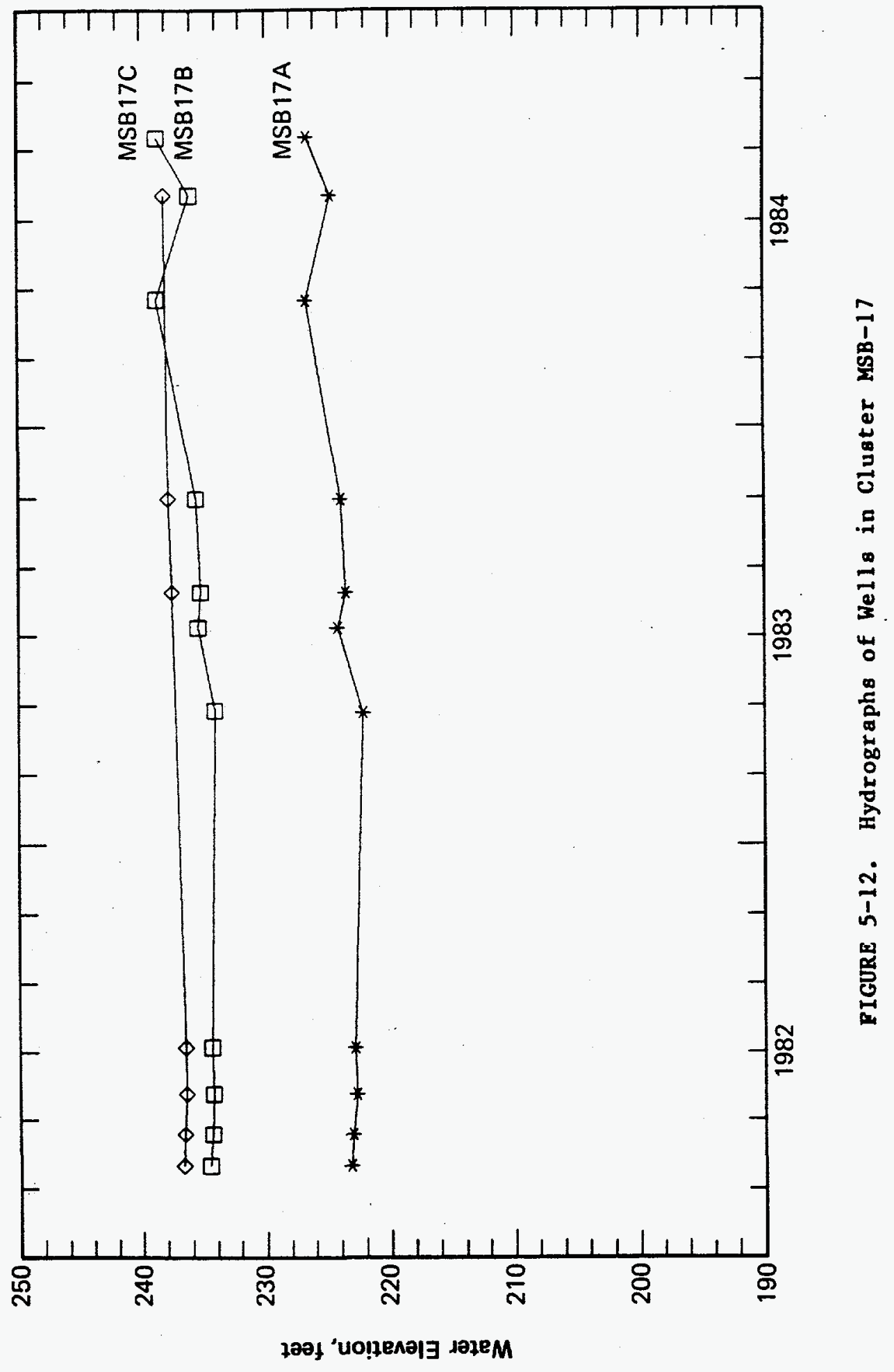




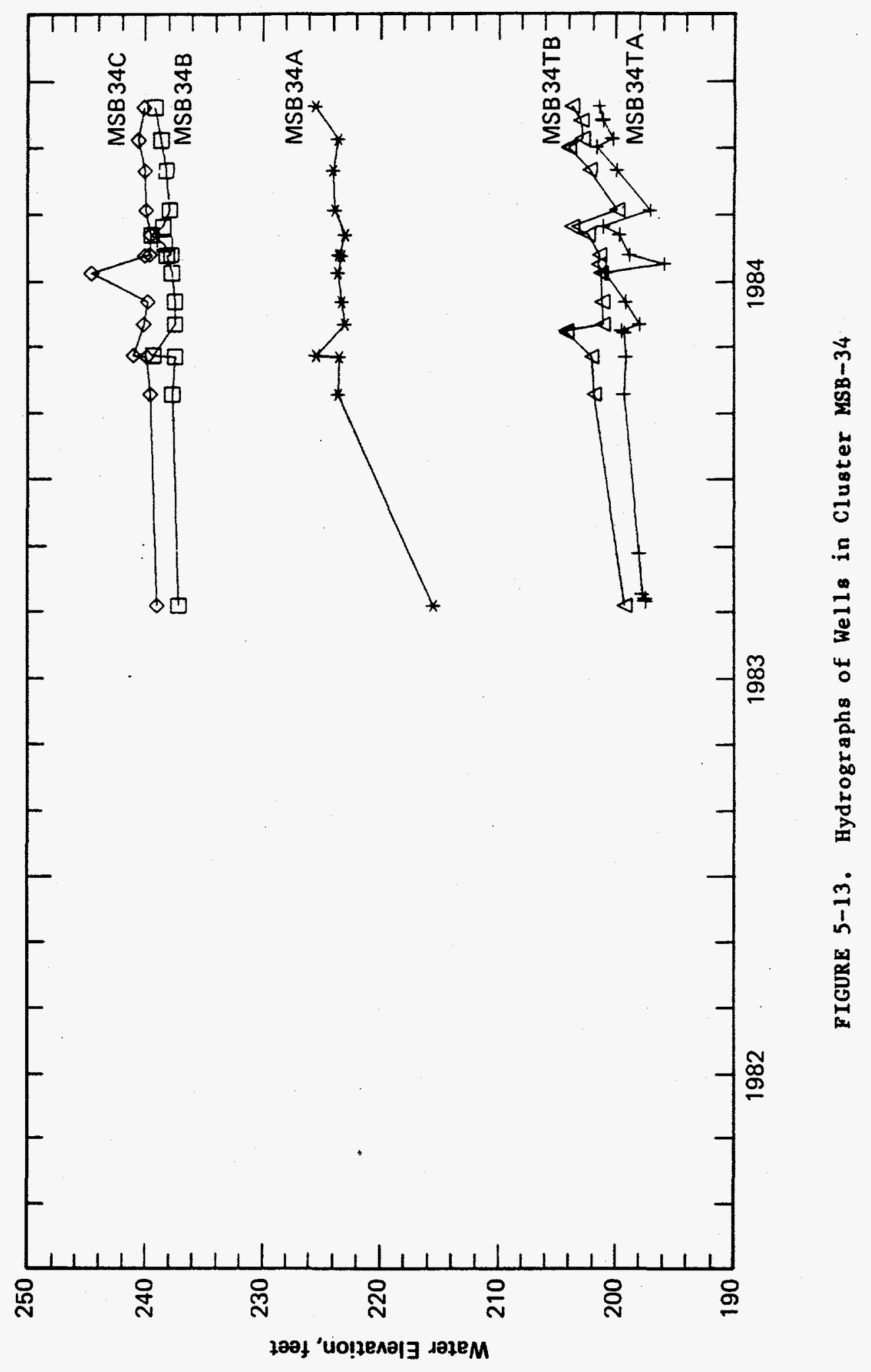

5-31 


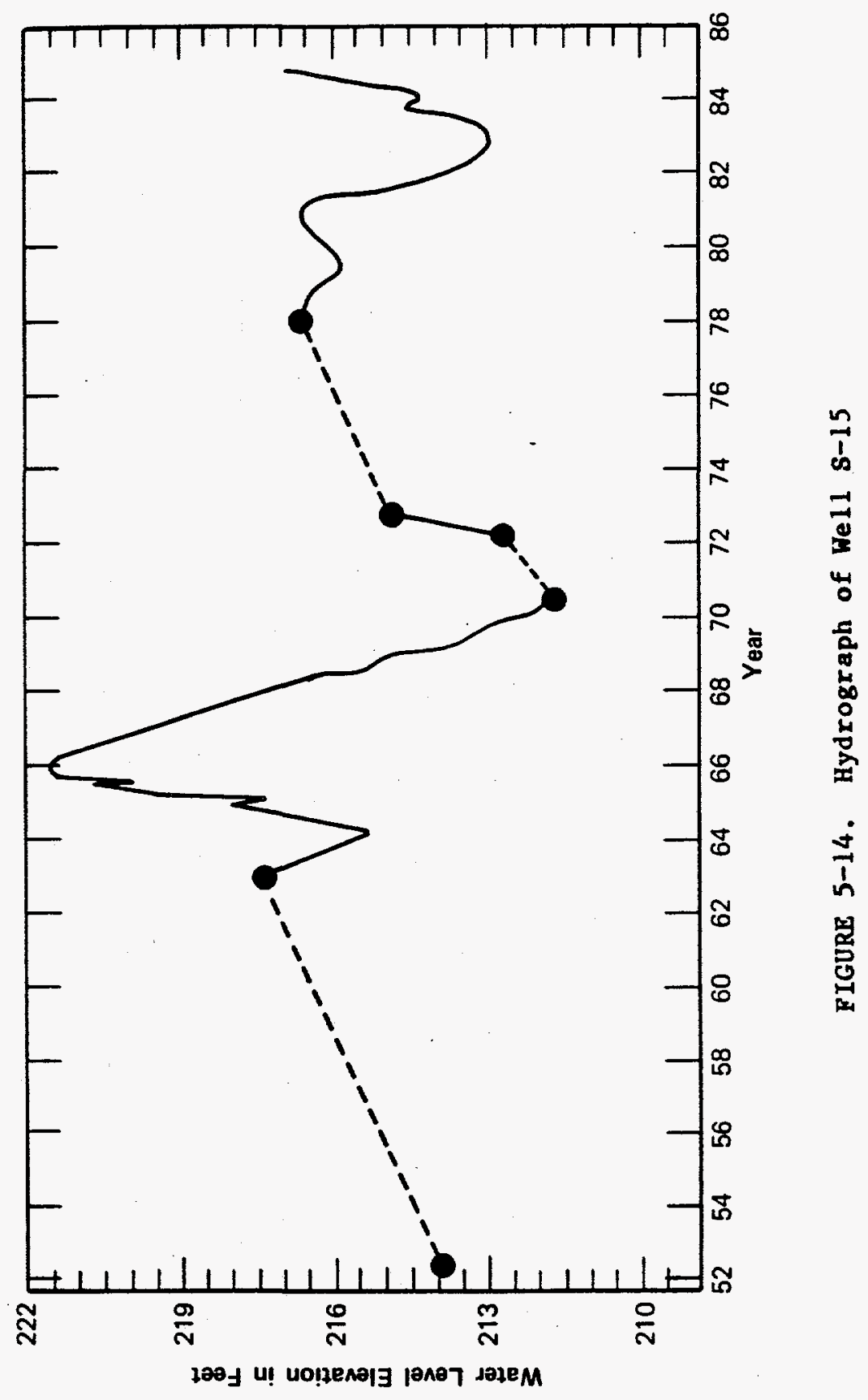




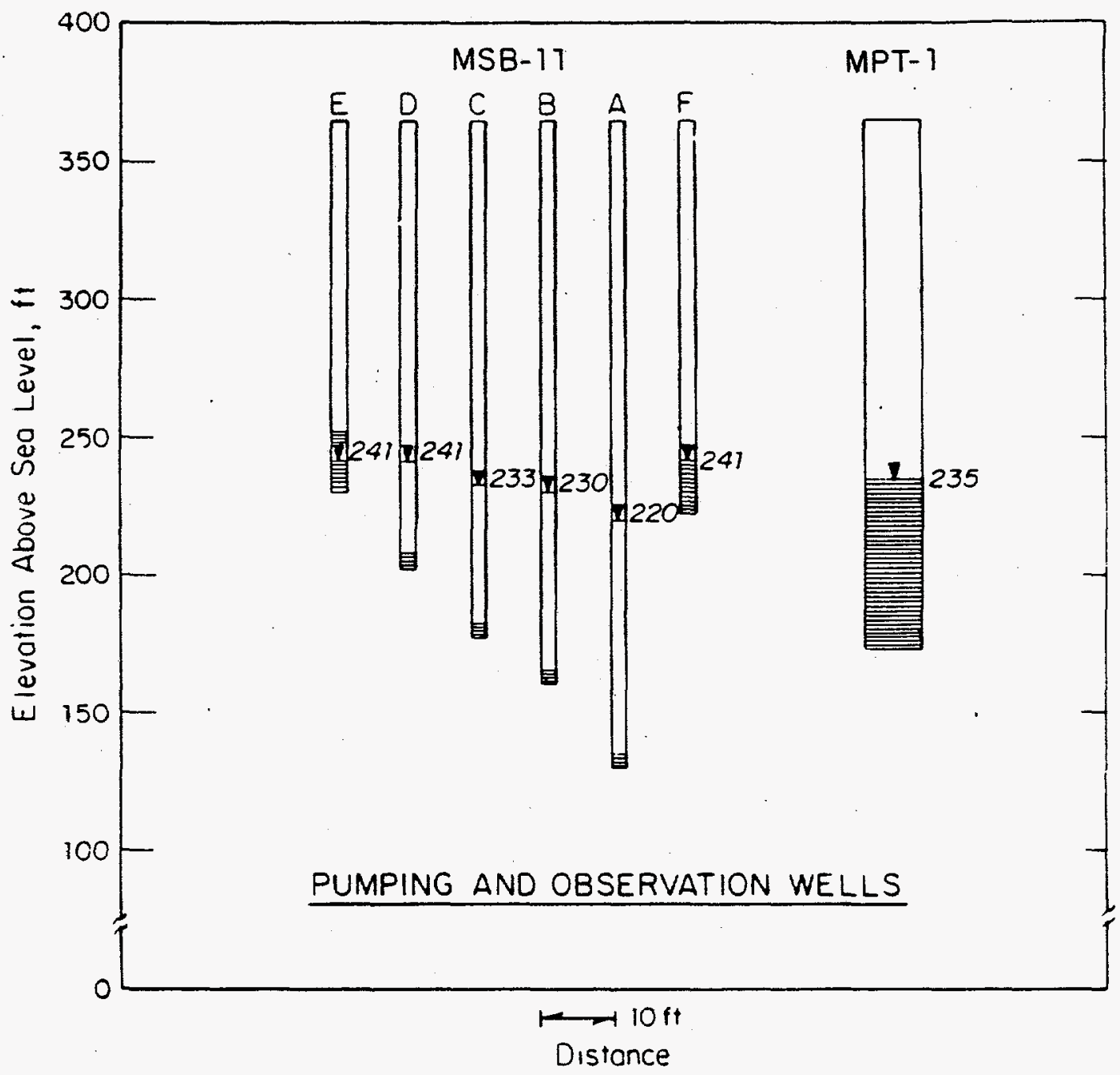

FIGURE 5-15. Schematic Section of Screen Zones and Water Levels of MSB-11 Well Cluster and Production Test Well 


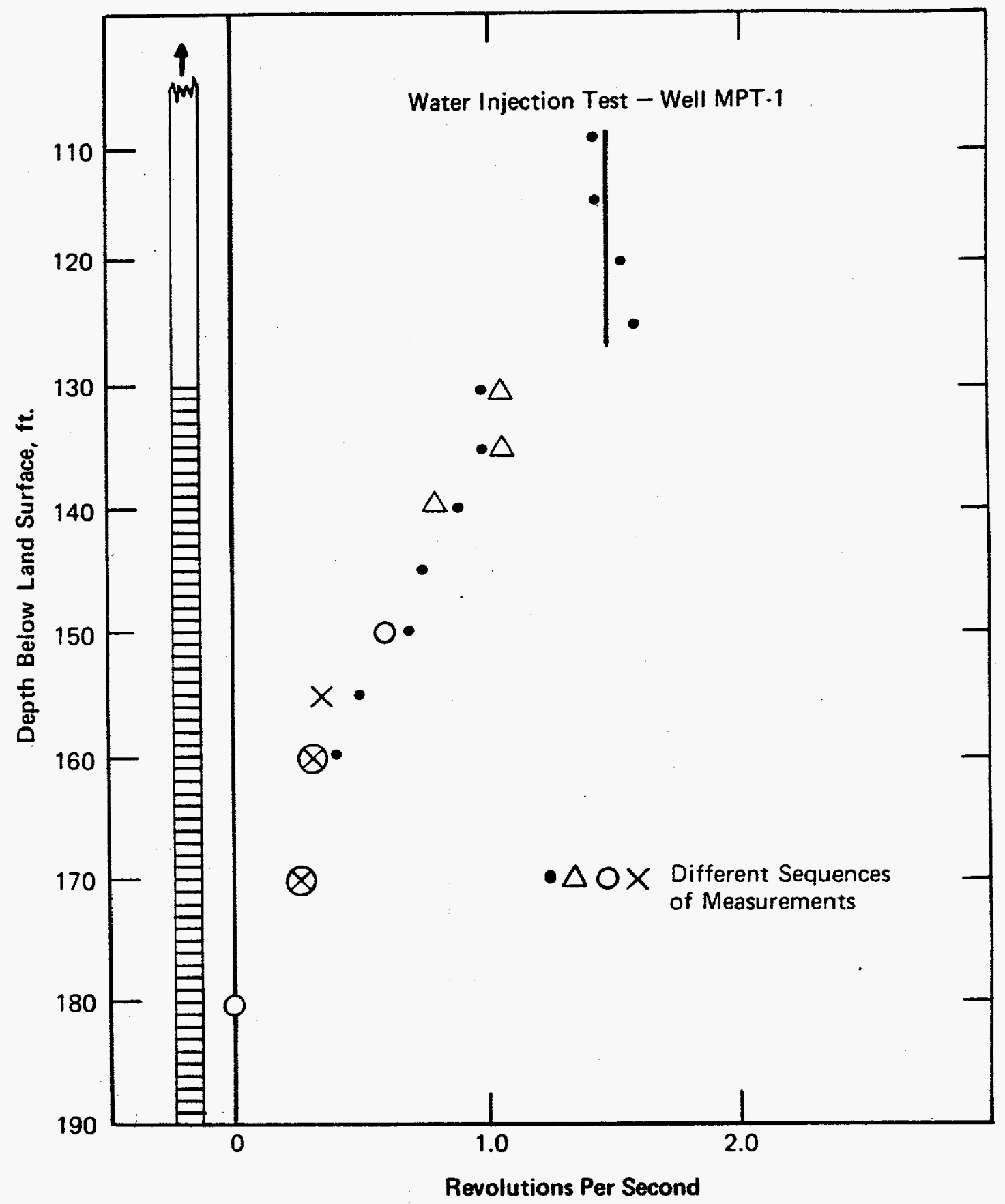

FIGURE 5-16. Results of Water Injection Test on MPT-1 


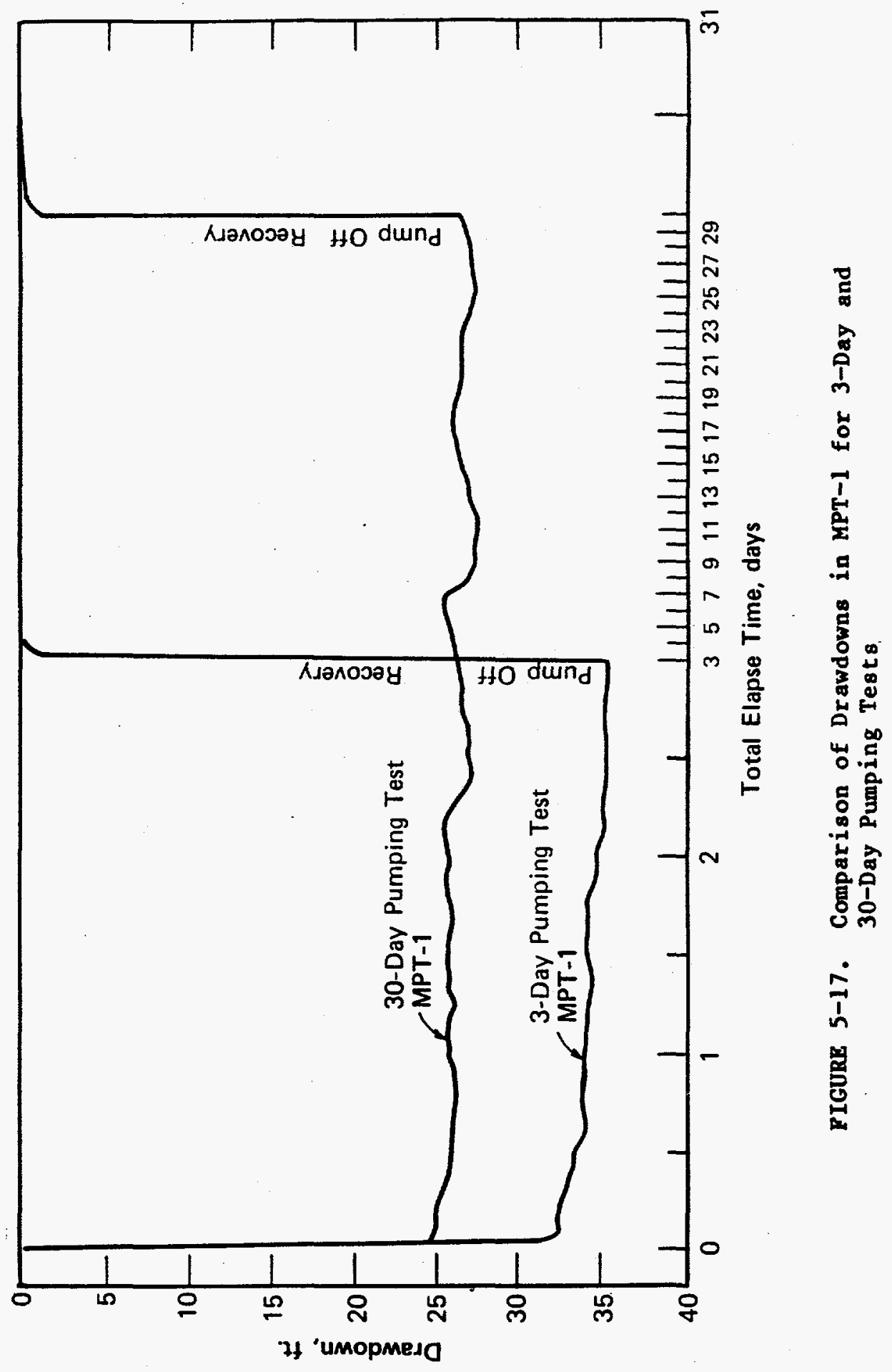




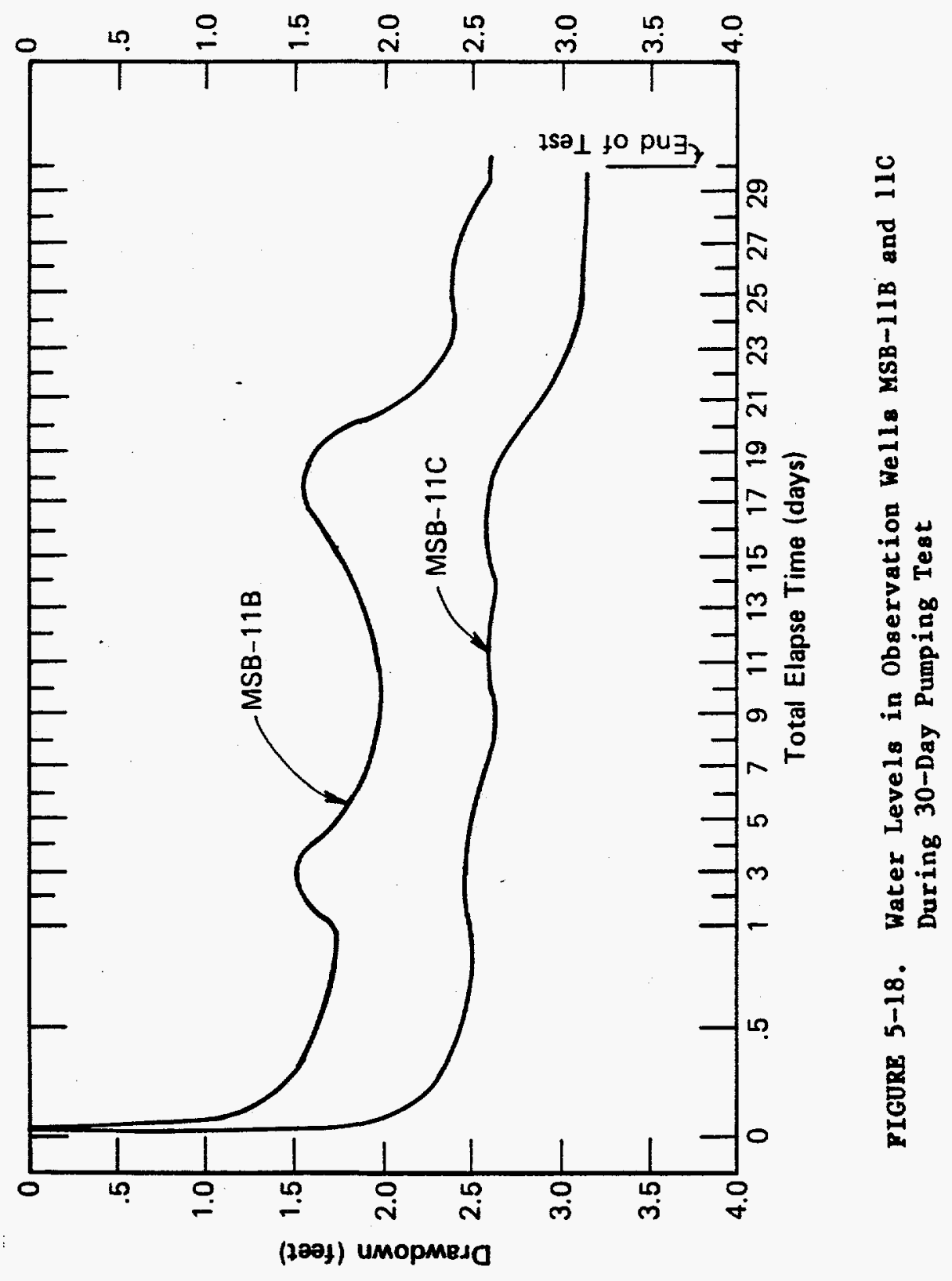




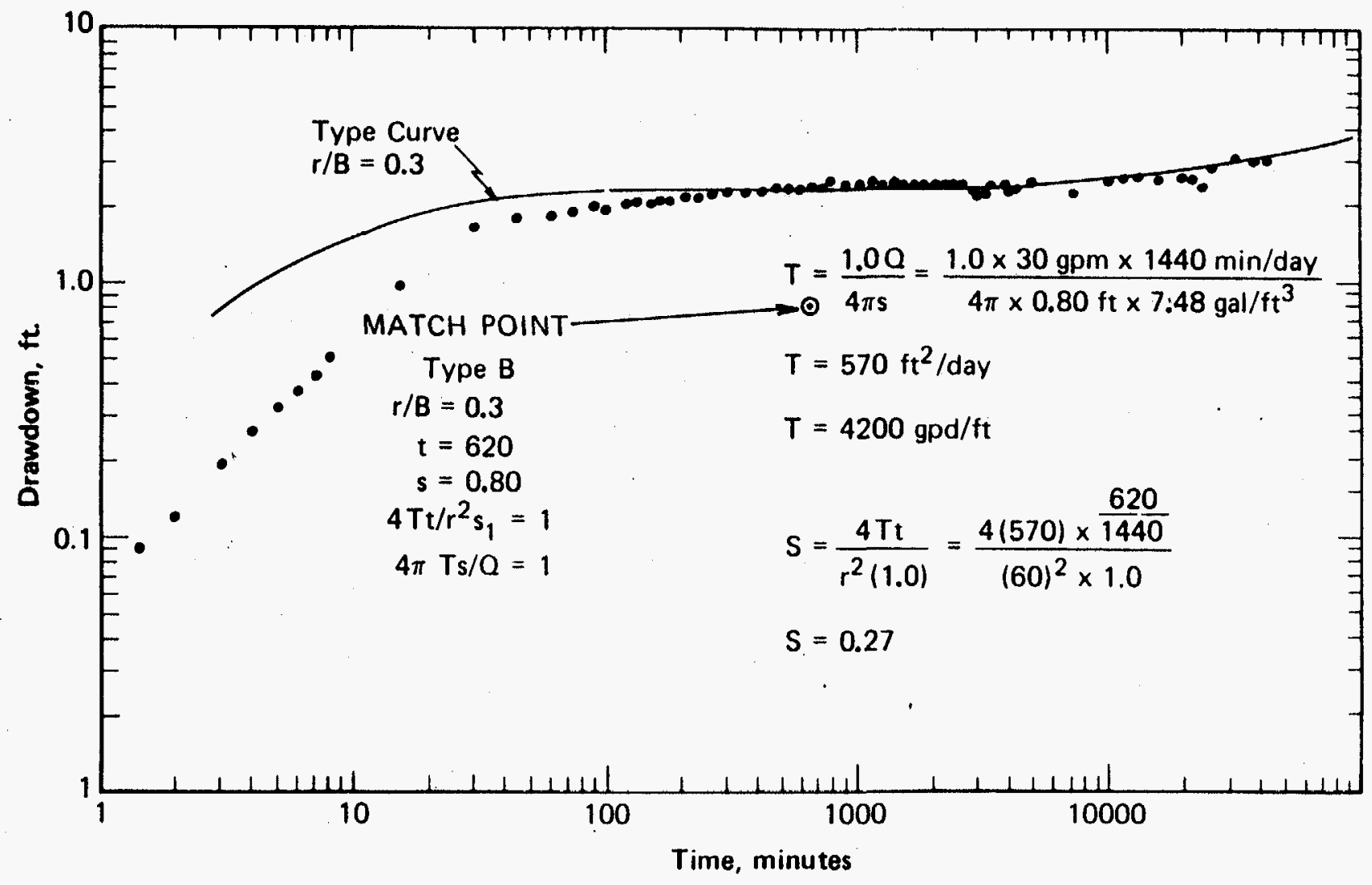

PIGURE 5-19. Log-Log Plot of Drawdown for Observation Well MSB-11C During 30-Day Pumping Test 


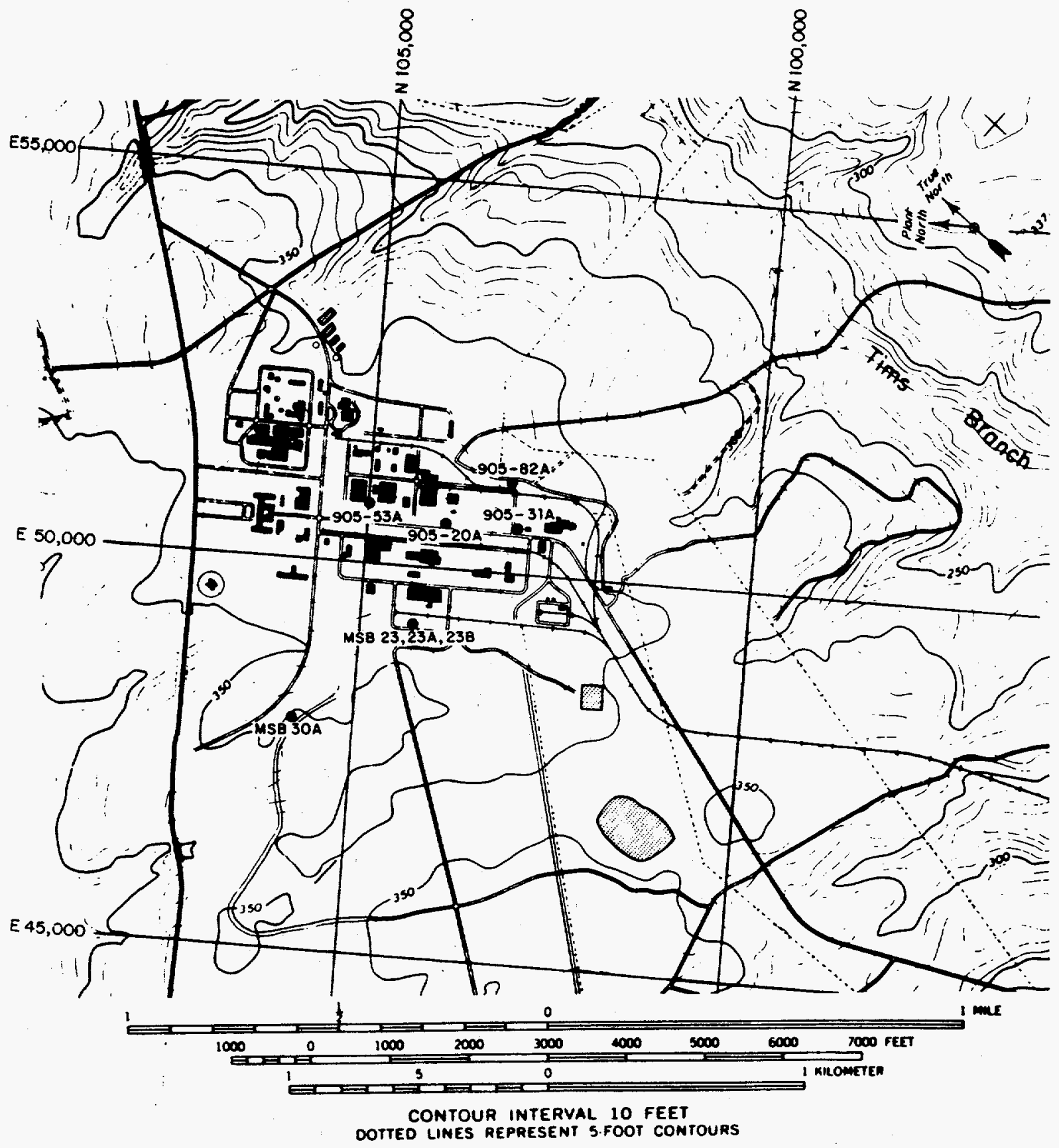

FIGURE 5-20. Location of Wells Utilized in the "Tuscaloosa" Pumping Test 


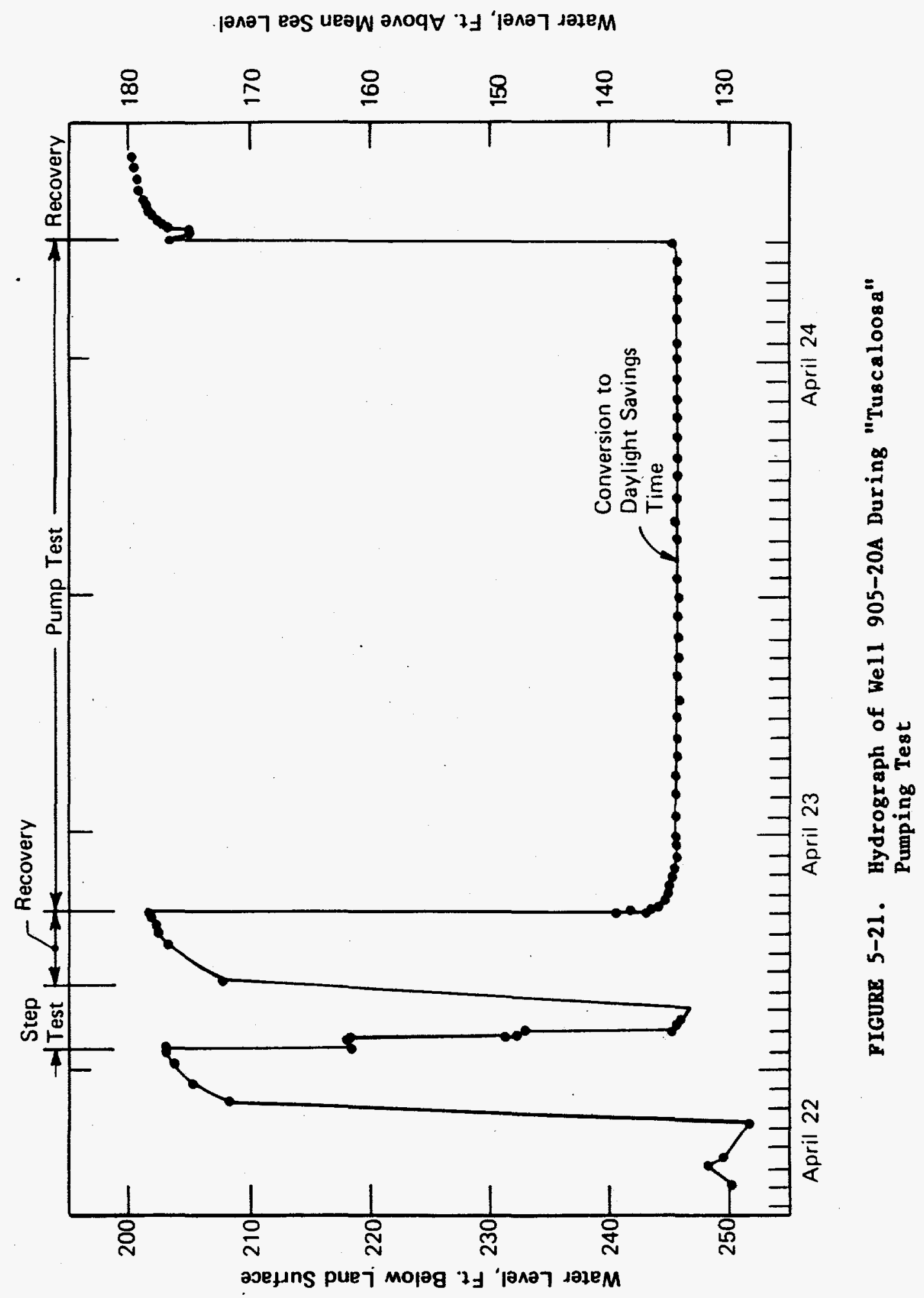




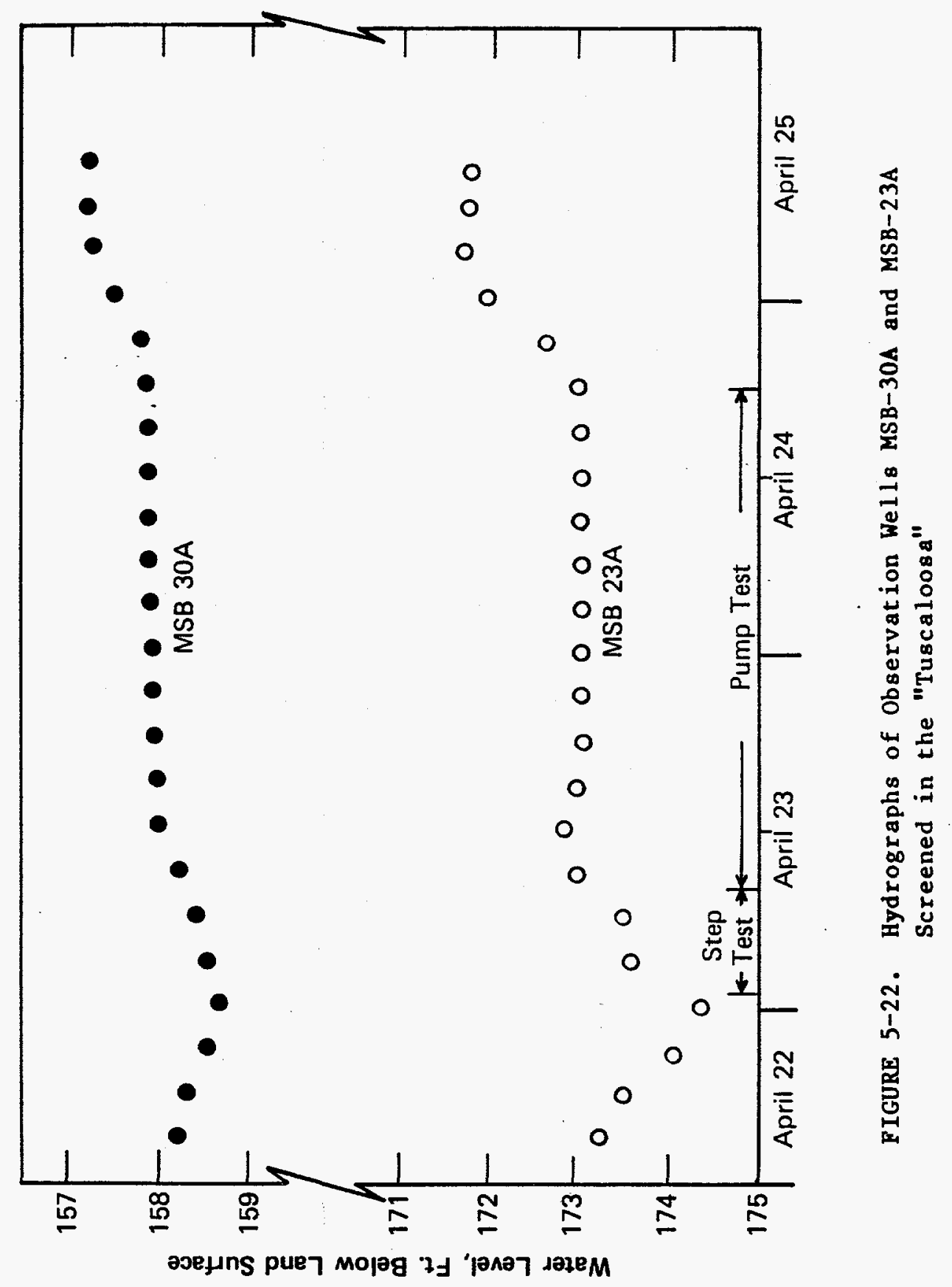




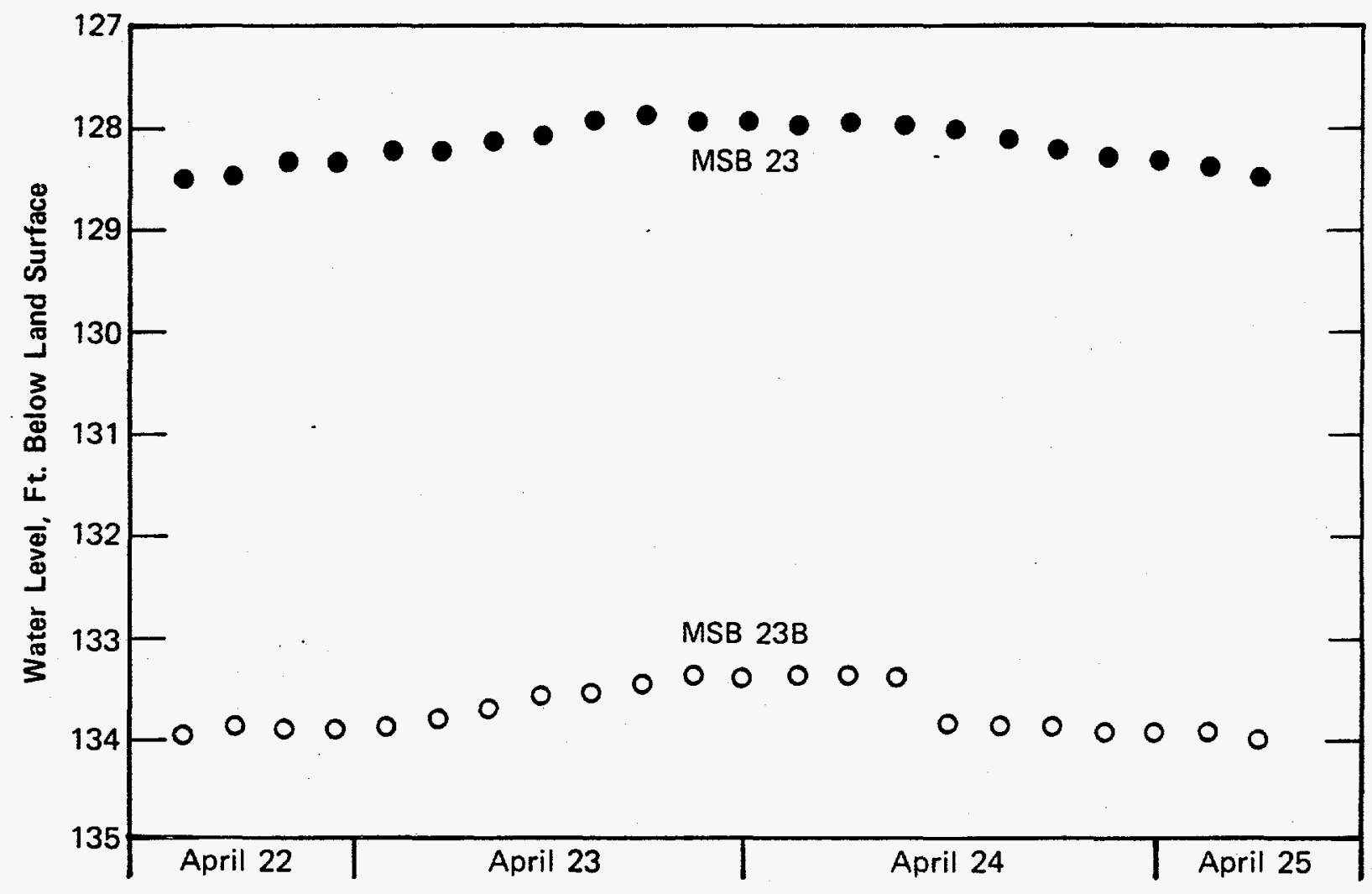

Fig. 5-23. Hydrographs of Observation Wel1s MSB-23 and MSB-23B Screened in Tertiary Sediments 


\subsection{Introduction}

The facilities for fabricating fuel and target elements to be irradiated in SRP reactors are located in the 300-M Area. During fabrication, fuel and target elements are degreased at several stages in the process. They are also cleaned at other stages with hot caustic and hot nitric acid. From 1952 to 1982, M Area used an estimated 13 million pounds of chlorinated degreasing solvents (Table 6-1). Although 50 to 95 percent of the solvents evaporated during degreasing operations, the remainder went to the M-Area process sewer system. It is estimated that 2 million pounds may have been released to the sewer that leads to the M-Area settling basin and about $1-1 / 2$ million pounds to the A-14 outfall (Christensen and Brendel1, 1982).

M-Area degreaser facilities are located in Buildings 313-M, 320-M, and 321-M (Figure 6-1). Degreaser facilities consist of large vats partitioned in half. On one side the solvent is boiled and the vapors degrease items exposed to them. These vapors flow to the other half of the $v$ at where they are condensed and collected. After condensation, the degreasing fluid overflows from the cool side of the vat to the hot side where it is again vaporized for use in degreasing. Over time oil and grease extracted from components accumulate in the solvent solution and raise its boiling point. With the same amount of heat input, less solvent vapors are generated and cleaning efficiency drops. Periodically the contents of the large tube cleaning vats in $320-M$ and $321-M$ flow through a still to recover solvent. The smaller vats in $313-M$ are periodically emptied and clean solvent substituted. In the past, spent degreaser solvent was either drained into the process sewers, or pumped into drums and then distilled for reuse. Occasionally, during the seventies, still bottoms, degreaser sludges, and some solvent were collected in drums and stored on concrete pads awaiting distillation recovery. Beginning in 1979 , all waste solvents and sludges were drummed and stored in Building 710-U, a hazardous waste storage facility. 


\subsection{History and Locations of Potential Degreaser Solvent Releases}

Much of the information contained in the following section is not contained in verifiable records and cannot be substantiated. It was largely compiled by H. L. Martin (1984), a process engineer in $M$ Area, who obtained it by interviewing several employees who worked or had worked in $M$ Area. The primary uses of the following information are to explain known plume patterns, to provide information for the study of plume migration rates, and to provide information on possible sources of chlorocarbon contamination.

Buildings $313-M$ and $320-M$ were operational by the end of 1952 and used trichloroethylene as the degreasing agent. The trichloroethylene was shipped to SRP in tank cars. Although there is not a consensus agreement among employees, it appears that tank cars were used as a storage facility while located on the railroad siding (site "A", Figure 6-1). Solvent was pumped from the tank $c$ ar into pipelines to 313-M and from there to Building 320-M. Spills are likely to have occurred during tank car unloading operations, but none are documented. A ditch (" $B$ ", Figure 6-1) drained the vicinity of $313-M$ to the back of $320-M$ and then to a low swampy spot where 321-M was eventually built ("C", Figure 6-1). Waste degreasing solvent from $313-\mathrm{M}$ and $320-\mathrm{M}$ was released to the process sewer ("D", Figure 6-1) that drains to the A-14 outfall. This outfall discharges to a tributary of Tims Branch.

In addition to the use of degreasing solvents in M Area, degreasing solutions were used in the reactors and other areas of the plant. For example, each reactor area had a 1000-gallon degreaser, SRL had two 450-gallon degreasers and the maintenance shops in Building 717-A had one 50-gallon degreaser. However, $M$ Area was the primary user and many shipments of solvent came to $M$ Area before being sent to other areas. To accomnodate the shipping of degreasing solvents to other areas of SRP, a drum loading facility was established at the south end of 313-M ("E", Figure 6-1).

Building 321-M was constructed in 1957 with three new degreasers. In order to contain the uranium wastes from the processes in $321-M$, the settling basin was built and began receiving process waste which included waste solvents through a second process sewer ("F", on Figure 6-1). After one or two years of use, the basin became partially plugged to water seepage and began to overflow. The overflow traveled along an engineered ditch ("G", Figure 6-1) toward Lost Lake - a natural upl and depression (Figure 6-1). (Editorial Note: A recently completed soil survey showed that the soils in the areas that recieved basin overflow do not contain degreaser solvents in significant concentrations [Pickett, 1985].) 
Accompanying the operation of $321-\mathrm{M}$ in 1957 , a number of changes were made in the handling of degreasing solvents. The solvent storage tank was built behind 321-M. This meant that railroad tank cars were no longer used as the primary solvent storage facility. From the incoming tank cars, the solvent was pumped into the $17,000-\mathrm{gall}$ lon storage tank. The drum loading station, however, remained at the south end of 313-M. Spills and leaks probably occurred in the vicinity of the solvent storage tank from off-loading the railroad tank cars and at the drum loading facility that continued to supply other plant areas with solvent. Although no specific spills or leaks were documented, groundwater monitoring data substantiate that significant spills occurred at the solvent storage tank.

Because the area around 321-M was still swampy when $321-M$ was completed in 1957, a drainfield was installed that discharged to the south and west of the facility ("H", Figure 6-1) but most drainage was still to the natural draw ("I", Figure 6-1) over the head of which 321-M had been built.

In $1962,313-M$ redesigned its process and tetrachloroethylene was substituted for trichloroethylene. Trichloroethylene continued to be stored in the solvent tank and was pumped to the drumming facility. Tetrachloroethylene was discharged through the process sewer leading to the A-14 outfall.

During 1971, 320-M and 321-M substituted tetrachloroethylene for trichloroethylene, and the solvent storage tank was changed over to tetrachloroethylene use. By 1972 efforts were under way to limit uranium discharges from $313-M$ to the $A-14$ outfall. One of the 313-M sewer lines was connected to the main process sewer going to the settling basin in early 1973. Consequently, about one-half of the solvent going to Tims Branch from 313-M was diverted to the settling basin. Three years 1 ater additional changes were made so that all process discharges from $313-M$ and $320-M$ went to the settling basin.

In 1979 the use of tetrachloroethylene was stopped, and $1,1,1-t$ richloroethane was used. On the conversion, the excess tetrachloroethylene was apparently disposed of into the settling bas in sewer al though no documentation exists.

After degreasing solvents were found in the groundwater below the M-Area basin in 1981, television surveys were made in 1982 of both the process sewer to the settling basin and the one to the A-14 outfall. Some cracks were observed in the terra cotta pipe to the basin ("F", Figure 6-1). In places fine plant roots penetrated into the sewer. The television camera was mounted on a floating 
sled, so it only observed the upper part of the sewer pipe and not the part covered with liquid. This pipe was relined in 1984 . The pipeline to the A-14 outfall also had small cracks over most of its length. Furthermore, the pipe labeled " $\mathrm{J}$ " on Figure 6-1 was heavily corroded. The sewer to the A-14 outfall was relined in 1983.

The Savannah River Laboratory has also operated degreasers in the past in the basement of Building 773-A (Figure 6-1), but does not do so at present. In 1954-55, two 450-gallon capacity degreasers were installed in the two chemical cleaning rooms in the Fabrication Laboratory. These degreasers could be used as vapor degreasers or dip vats depending on the object to be degreased. When the vapors were used, the object dried immediately When dipping was used, the object went into a rinse tank after

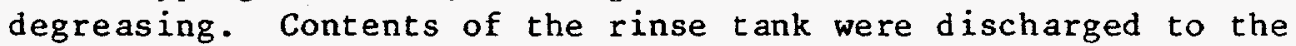
trade waste stream which discharges at the A-1 outfall (Figure 6-1). The degreaser facilities were in use 70 to 80 percent of the time in the 1950's when consumption was 30-40 drums per year. During the 1960's usage declined to 30 percent of the time. In the 1970's. usage declined even further. Each degreaser was equipped with a still. Once or twice soda ash was used to boil out the still bottoms (grease). That solution was discharged to the trade waste stream. In 1962, a 30-gallon capacity degreaser was added at the nickel plating facility. In 1964 because of declining usage, one of the 450-gallon degreasers was removed and in 1973 the small degreaser was removed. Also in about 1973, the solvent used in the one remaining degreaser was changed from trichloroethylene to tetrachloroethylene. In 1979, the solvent was to be changed to 1,1,1-trichloroethane, but usage had so declined by that time, that the old solvent was removed but the degreaser was never loaded with the new solvent. The degreaser has not been used since 1979 .

The central maintenance shop is located in Building 717-A (Figure 6-1). A vapor/dip degreaser was located on a concrete pad outside of the eastern corner of Building 717-A, about 10 feet from the wall of the building. It had a capacity of about 50 gallons, and about 50 gallons per year were used. It was underlain by a sump pit which could drain to a storm drain. The degreaser was removed in 1977 but used trichloroethylene as a solvent up until that time.

Although degreasers in the reactor areas were supplied from the M-Area drumming facility, the degreasers in Building 773-A and 717-A were mostly supplied from Central Stores which stocked 
the solvent. In the 1950's, degreasing solvent could be obtained from chemical stores located in Building 773-A, but in the mid 1960 's the dispensing of solvent was transferred to Central Stores in Building 713-A (Figure 6-1). In 1975-76 about 90 gallons per month of trichloroethylene were dispensed from Central Stores. In August, 1977 the solvent was changed to tetrachloroethylene and about 24 gallons per month were dispensed until May 1978 when it was removed from stores. The stock at Stores was in 55-gallon drums from which it was pumped into smaller containers for distribution. The storage facility was in a small building at the north end of 713-A, where paint was also stored.

\subsection{Magnitude of Degreaser Solvent Releases}

Figure 6-2 shows the time of usage of the three degreaser solvents in M Area. Table 6-1 shows the estimated amount of each of the three degreaser solvents used and released to the settling basin and the A-14 outfall (Christensen and Brendell, 1982). The usage of tetrachloroethylene and 1,1,1-trichloroethane was estimated from former purchase records. Trichloroethylene records are not available and use-estimates are developed from M-Area personnel judgements. Each reactor area has one degreaser of 1000 gallon capacity and received one to two barrels of solvent per month from M-Area stocks. Total allocations from M Area to these facilities were estimated to range from 25,000 to 50,000 pounds of solvent annually. M-Area solvent consumption estimates given in Table 6-1 were adjusted accordingly.

Estimates of the amount of solvent released to the process sewers leading to the settling basin and to the $A-14$ outfall are given in Table 6-1. The percentage of solvents reaching the $M-A r e a$ process sewers was estimated based on several factors:

1. Waste solvent and sludge disposal practices

2. Age of degreasers and replacements

3. Change in annual purchases

The solvent discharge estimates include:

- Leakage from degreasers

- Dirty solvents and sludge which were drained from degreasers and distillation tanks

- Spills

- Temporary storage of solvents and sludge which were subsequently discharged to the process sewers. 
Figure 6-3 shows the estimates of annual discharges of degreaser solvents to the process sewers leading to the settling basin and the A-14 outfall. It must be emphasized that there are no records of solvent discharges, and these estimates are mostly based on judgements of individuals. However, they are probably the best estimates that will be developed, and they show relative magnitudes.

Apart from the release to the process sewers leading to the settling basin and to the A-14 outfall, it is not possible to estimate the quantities of degreaser solvent, such as spills around the storage tank, that actually penetrated the ground. Locations of these areas are shown in Figure 6-1 and discussed in Section 6.2 .

It must be emphasized in summary that although it is believed the major places where solvents could have entered the ground have been identified from the process history of the area, spills may have occurred at other locations also.

From Figure 6-3 and Table 6-1 it is apparent that larger quantities of tetrachloroethylene have been released than of trichloroethylene. However, several studies ( $\mathrm{Cl}$ ine and Viste, 1984; Parsons et al., 1984) suggest that tetrachloroethylene degrades anaerobically to trichloroethylene; thus it cannot be assumed that all trichloroethylene found in the ground began as that substance.

\subsection{Sources of Substances Other than Degreaser Solvents}

Before construction of M Area there was a draw or depression ("C", Figure 6-1) that passed beneath 321-M and then turned northward past 320-M and thence northwestward. One of the first operations of construction in 1952 was to grade the area and fill in this draw. Thus extensive earth moving equipment was employed. At location "K" on Figure 6-1 there was a fuel oil storage depot.

Many of the processes in all three M-Area facilities involve cleaning with caustic (sodium hydroxide) and hot nitric acid. These substances have been discharged to the process sewers. The nitric acid, even if neutralized, is a source of elevated nitrate discharges, some of which have migrated to the groundwater. It has been found in other areas of SRP that effluents high in sodium hydroxide tend to cause soil particles to swell and plug the soil pore spaces. Such discharges may have been responsible for the partial pluggage of the M-Area settling basin about two years after its operation began. 
The purpose of the settling basin was to settle out uranium and heavy metals. Elevated concentrations of heavy metals have been found only within the shallow soil beneath the bottom of the basin (Hollod, 1982), indicating that the basin served its intended purpose well. 


\section{References Por Chapter 6}

Christensen, E. J. and C. R. Brendell, 1982. Chlorinated Solvent Releases to H-Area Process Sewers, DPST-81-968, E. I. du Pont de Nemours and Company, Savannah River Laboratory, Aiken, SC.

Cline, P. V. and D. R. Viste, 1984. Migration and Degradation Patterns of Volatile Organic Compounds, in The 5th Conference on Management of Uncontrolled Hazardous Taste Sites, November 7-9, 1984, Hazardous Materials Control Research Institute, Silver Spring, MD.

Hollod, G. J., I. W. Marine, H. W. Bledsoe, and J. P. Ryan, 1982. Hetals and Organics in the Soil Beneath the H-Area Settling Basin, DPST-82-721, E. I. du Pont de Nemours and Company, Savannah River Laboratory, Aiken, SC.

Martin, H. L., 1984. Personal Communication.

Parsons, F., P. R. Wood, and J. DeMarco, 1984. Transformations of Tetrachloroethene and Trichloroethene in Microcosms and Groundwater, Journal of the American Water Works Associations, February 1984, PP. 56-59.

Pickett, J. B., 1985. Extended Characterization of M-Area Settling Basin and Vicinity, DPSTD-85-121, E. I. du Pont de Nemours and Company, Savannah River Laboratory, Aiken, SC. 
TABLE 6-1

Estimated Quantity of Degreaser Solvent Released to M-Area Process Sewers

$\begin{array}{lcccc}\text { Solvent } & \begin{array}{l}\text { Total } \\ \text { Used }\end{array} & & \begin{array}{l}\text { Estimated } \\ \text { Release to } \\ \text { Settling Basin }\end{array} & \begin{array}{l}\text { Estimated } \\ \text { Release to } \\ \text { Tims Branch }\end{array} \\ \begin{array}{l}\text { Trichloroethylene } \\ \text { Tetrachloroethylene }\end{array} & 3,700 & 317 & 383 \\ \begin{array}{l}1,1,1-T r i c h l o r o e t h a n e \\ \text { Total }\end{array} & 8,700 & 1,800 & 1,000 \\ - & 13,070 & 2,136 & 1,395\end{array}$

Units are $10^{3}$ pounds 


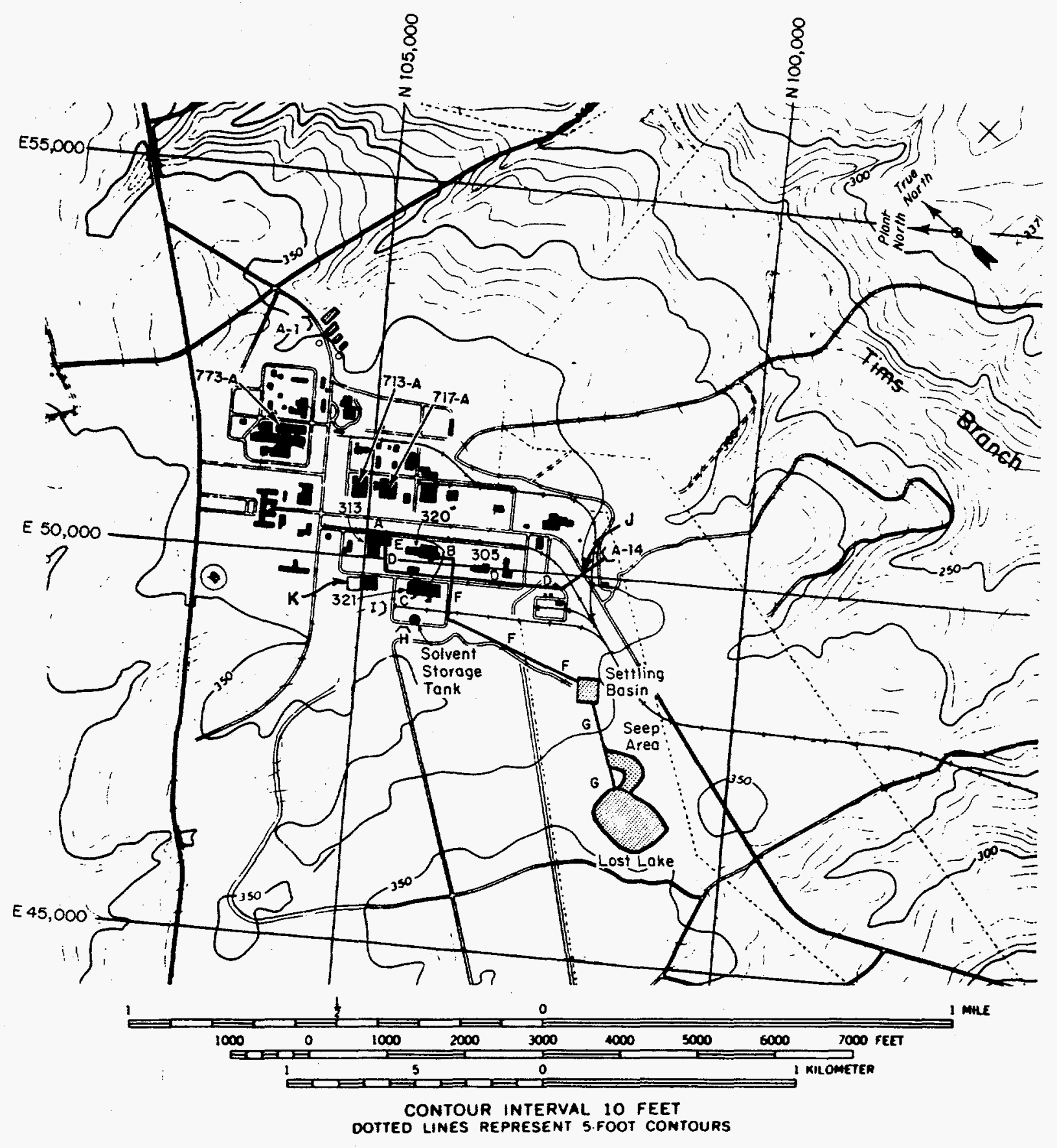

FIGURE 6-1. Locations of Potential or Suspected Contaminant Releases (See Text Chapter 6 for Discussion of Symbols.) 


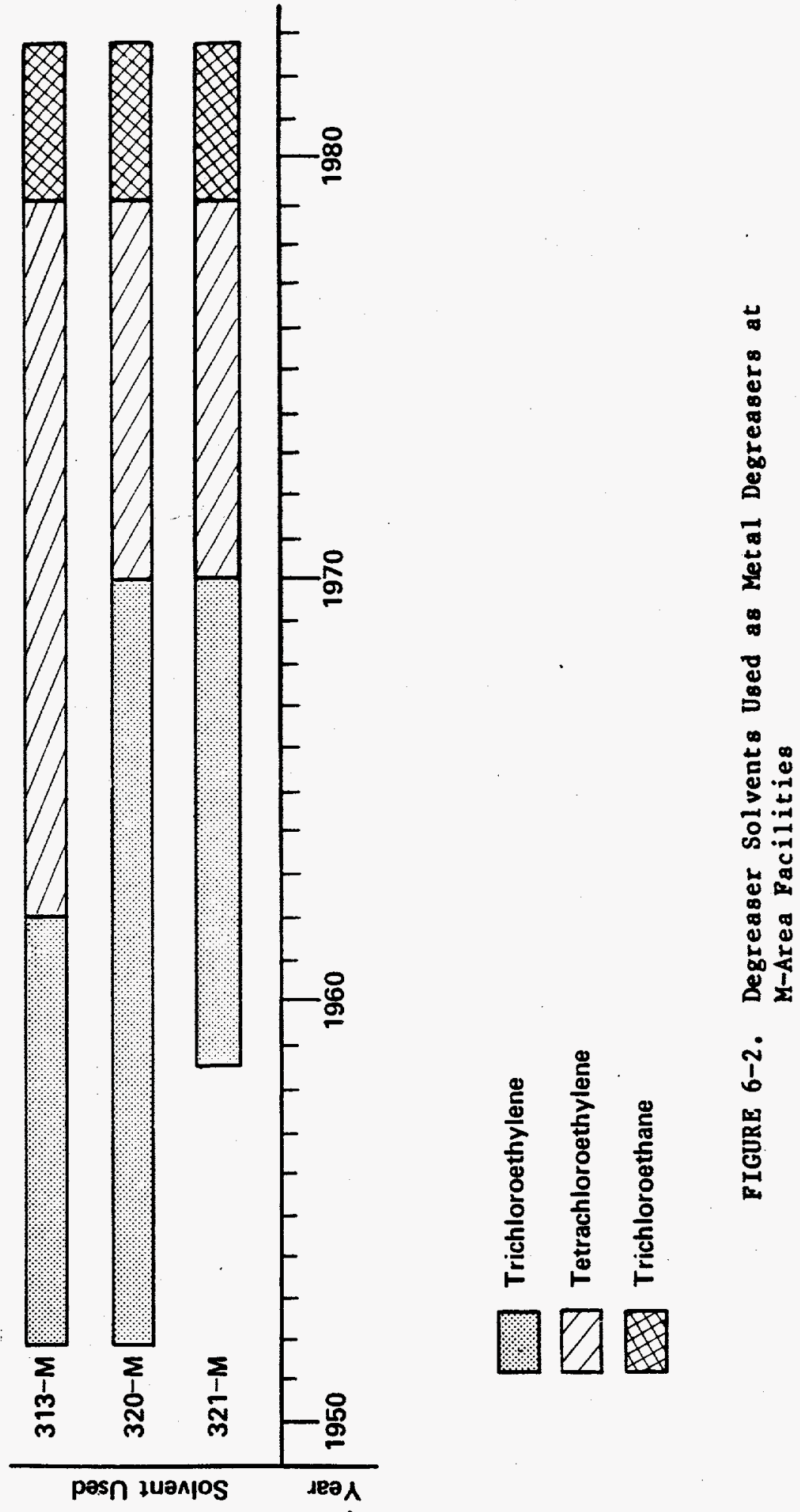

6-11 


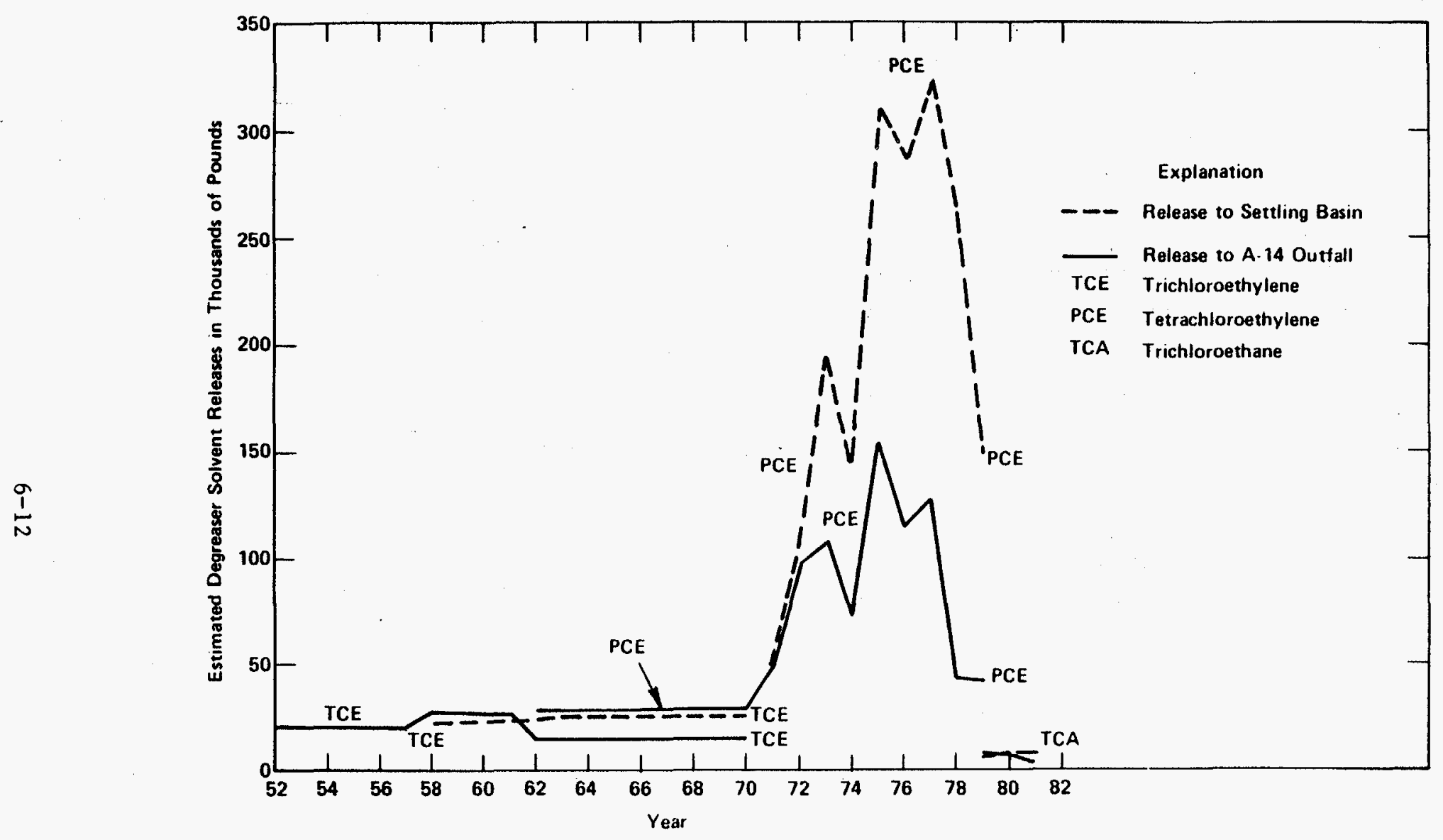

FIGURE 6-3. Estimated Annual Discharge of Degreaser Solvents to the Process Sewers 


\subsection{Degreaser Solvents in the Tertiary Sediments}

The results of the subsurface investigations of the undifferentiated Tertiary sediments indicate that there are three main centers or sources for the groundwater contamination: the M-Area basin and the pipeline from the manufacturing facilities to the basin; the M-Area process facilities apparently centered around the solvent storage tank behind $321-M$; and the sewer outfall to the Tims Branch tributary stream near well MSB-31. These areas show the highest concentration of degreaser solvents in both soil and water samples. Total concentrations of degreaser solvents as high as $542,000,130,000$, and $362,000 \mathrm{ppb}$ were obtained from analyses of water samples collected near the basin (MSB-3A), near the solvent storage tank (MSB-23), and near the A-14 sewer outfall (MSB-31C), respectively.

A comparison of the results of the soil and water analyses from wells installed at the same location for this phase of the investigation is shown by bar charts on Figures 7-1 through 7-6. From these graphs, there appears to be a predominance of trichloroethylene over tetrachloroethylene in the water. In the soil analyses the two are about equal. The results of earlier soil analyses compared to water analyses are presented in the Preliminary Technical Data Summary, M-Area Groundwater Cleanup Facility (Gordon, 1982).

The results of the analyses of water samples collected from the monitoring wells for degreaser solvents are presented in Appendix B. During this phase of the investigation a sample collection protocol was prepared and adopted for use in the collection of water samples. A copy of the protocol is presented in Appendix E-1.

A contour map of the vertical average total organic concentrations found in the groundwater between April and July 1984 is presented on Figure 7-7. These contours are at best only an approximation of the horizontal shape and concentration of the groundwater contaminant plume. These maps can only be approximate since there are very little data available at some vertical 
sections of the map. Also most of the investigative effort to date has concentrated to the west and southwest of the basin and south of the production facilities. At increasing distances from the sources of surface contamination the higher concentrations are generally depressed below the water table. For example, wells located at sites MSB-26 and 27 show very low concentrations of degreaser solvents at the water table, but in the deeper wells at the same locations, the concentration increases to $\sim 34,000$ and $62,000 \mathrm{ppb}$, respectively (Appendix B).

Two vertical sections across the contaminant plume are shown on Figures 7-8 and 7-9. The locations of the two profiles are shown on Figure 7-10. The profiles show the plume sinking and dispersing as the contaminant moves down the groundwater gradient. The sinking of the plume shown on Figure 7-9 is aided by the discharge of noncontact cooling water and storm runoff from the $M-2$ outfall (Figure 5-2).

The previously referred to maps and profiles provide a generalized view of the contaminant plume, however, a more specific view may be obtained from maps of the contaminant plume at selected levels in the ground. Figure $7-11$ is a map of the contaminant plume at the water table for the spring of 1984. Figures 7-12 and 7-13 are maps of the contaminant plume at elevations between 146 and 187 feet above sea level, and between 100 to 144 feet above sea level, respectively. The elevation intervals correspond to those used for the potentiometric maps shown on Figures 5-4 and 5-5. The influence of both clean and contaminated past water discharges can be seen by comparing these maps. In the area where Figure 7-9 shows the vertical section, the influence of the clean water discharge from the $M-2$ outfall may be seen as it drives the plume to greater depth. The influence of the "seep area" may be seen on the water table concentration map (Figure 7-11). The influence of discharged degreaser solvents at the A-14 outfall and their subsequent migration along the water table gradient may be seen on Figure 7-11.

These three maps show total concentration levels of trichloroethylene plus tetrachloroethylene. It may not be productive at this time to show these degreaser solvents separately because trichloroethylene is a breakdown product of tetrachloroethylene, in addition to being an original source material. Appendix $B$ or Figures 7-1 to 7-6 show that concentrations of trichloroethylene are generally higher in the groundwater than those of tetrachloroethylene, yet Figure 6-3 shows that estimated releases of tetrachloroethylene to the ground have been many times greater than those of trichloroethylene. Thus, transformations, as well as sorption phenomena, may be taking place in the ground after the release of tetrachloethylene, and it is more appropriate for general purposes to map the sum of the two degreaser solvents. 
By comparison with these two major degreaser solvents, the concentrations of 1,1,1-trichloroethane in the ground are very small. Only 10 wells consistently show concentrations of $1,1,1-$ trichloroethane greater than $10 \mathrm{ppb}$ and only two wells, MSB-12B and $12 \mathrm{C}$, show concentrations greater than $100 \mathrm{ppb}$.

An estimate of the inventory of degreaser solvents within the $100 \mathrm{ppb}$ contour in the saturated zone can be made using the contour maps of concentration at different elevation levels (Figures 7-11, $7-12$, and 7-13). Obviously, there is some subjectivity in contouring these concentrations and as more data are obtained, a better estimate of the degreaser solvent inventory can be made. Table 7-1 shows how an inventory estimated at 360,000 pounds in the saturated zone was obtained. The area occupied by the plume of degreaser solvents above $100 \mathrm{ppb}$ in concentration is more widespread in the middle Tertiary zone ( 360 acres) than at the water table ( 275 acres). However, there is a greater inventory in the water table zone $(244,000 \mathrm{lb})$ than in the middle Tertiary $(113,000 \mathrm{lb})$ because the maximum concentrations in the water table zone are much higher.

\subsection{Inorganic and Other Organic Characteristics of the Water From the Tertiary Sediments}

In the Spring of 1983 samples from selected wells were analysed for metals, major cationic and anionic contituents, radioactivity, and certain organic constituents. In the Spring of 1984 samples were collected from every well for analyses of metals, major cationic and anionic constituents, and certain organic substances. The samples from some wells were also analyzed for radioactivity. Table 7-2 gives a list of the elements, compounds, and properties for which samples were analyzed. Appendix $C$ gives the results of most of these analyses for both the 1983 and 1984 samples.

In several instances, the analyses were of a scan type (GC/MS priority pollutant $s c a n$ ) so that the limits of detectability were not as low as could be achieved with greater effort and cost. Since it was considered unlikely that these analytes would be present, it was not deemed worth that effort and cost unless their potential presence was indicated.

Analyses were made on 37 analytes that are not reported in Appendix $C$. One group is not reported because they are commonly used substances in laboratories, and the laboratory and field blanks had concentrations comparable to or greater than the results reported for the samples. Certain other analytes, although included in the secondary drinking water standards, were thought to be of little value in this study. One group is not reported because their concentration was never above detectability. In the introduction to Appendix $C$, the analytes which are not reported are listed with the reasons why. 
In Appendix $C$, all wells shown have analyses of samples collected in the spring of 1984. In addition, analyses are given for samples collected in 1983 on selected wells. The protocols by which both of these sets of samples were collected are given in Appendix E-1 for 1983 and E-2 for 1984. The samples collected in 1983 were not filtered for metal analysis, thus high values for metals in 1983 may include suspended solids as well as dissolved solids. For this reason only metal analyses for 1984 should be considered.

Compared to the relatively widespread plume of the two principal degreaser solvents, the general groundwater appears to be relatively free of other contaminants. Exceptions to this statement may exist beneath the principal sources of contamination, such as the settling basin (MSB-3A and 22), the solvent tank (MSB-23) and the $A-14$ outfall (MSB-31C).

Appendix $D$ presents chronological analyses for potential pollutants in groundwater around the M-Area settling basin (MSB 1-4) and around Lost Lake (MSB 5-8). The protocol for the collection and analysis of these samples is given in Appendix E-3.

In the discussion of individual analytes that follows, an attempt has been made to provide a statement of perspective on each analyte. Where drinking water standards have been promulgated, these usually provide such a perspective. The drinking water standards used are the national interim primary drinking water regulations (1977) and the secondary drinking water regulations (1979) as published by the Environmental Protection Agency (1979). Both of these standards are applicable to water systems that supply public drinking water to communities (except for nitrate which is also applicable to noncommunity water supplies). The primary standards are designed to protect human health. The secondary standards are not health related but cover contaminants that may affect the aesthetics, odor, palatability, or other characteristics of drinking water. The use of these standards for perspective in this report does not imply that the water should meet these standards, as the waters tested are not used for drinking nor are the samples taken from a free flowing outlet to a consumer. The standards are used in the perspective statement only for the purpose of providing a basis for comparison of the analyses given. Because many analytes do not have drinking water standards and also because in many cases the drinking water standard is too high to provide much perspective, other reference points must be given.

Hem (1970) discusses the study and interpretation of the chemical characteristics of natural waters, and this reference has been used for common levels of certain anayltes. Hem (1970) provides a global perspective on this subject, whereas Siple (1967, p.83) provides a more local perspective on the concentration of major 
constituents of groundwater in the vicinity of SRP. Where none of these references provide a perspective, the level of detectibility used by the contract laboratory that performed the analyses is used.

For certain analytes, such as magnesium, $\mathrm{pH}$, potassium, sodium and total dissolved soilids, the perspective values for limestones in the McBean and Congaree are appreciably higher than those for sands. Even though the geology around $M$ Area is predominantly sand, limy beds and residuum from 1 imy sands do occur. Thus, it seems appropriate to use the limestone value for perspective.

Most monitor wells were equipped primarily to sample for degreaser solvents and included a galvanized steel conductor pipe from the pump. The presence of galvanized steel in the wells, particularly ones with low $\mathrm{pH}$, may affect the resulting sample analyses for cadmium, iron, lead, and zinc even though four well volumes are removed prior to sampling.

A major advance in the interpretation of the spacial distribution of analytes was discovered by Van Price of the Savannah River Laboratory. $\mathrm{pH}$ above 10 is not possible without hydroxide being present, which it commonly is not in natural waters on the Coastal plain. The most available source of hydroxide, causing high $\mathrm{pH}$, is the leaching of the cement sheath that surrounds the casing. If there is cracking in the cement sheath such that water moves through it to the screen zone, the $\mathrm{pH}$ will be above 9 and the calcium and total dissolved solids will be high. An additional source could be that cement was not completely set and had entered the screen zone during the construction of the well. Whenever interpretation is being made for the pattern of an analyte, the potential for a leaking cement sheath or cement in the screen zone must be kept in mind. The natural waters in the McBean and Congaree Formations are quite low in $\mathrm{pH}, 4.2$ to 6.1 in the sands and 6.8 to 7.6 in the limestones. Wells with a pH greater than 9 , and thus suspected of having the analytes influenced by a leaking cement sheath or the presence of cement in the screen zone, are shown on Table 7-3.

Beyond these elevated values of certain analytes that probably do not represent elevated values in the ground, there are elevated values of certain analytes in the vicinity of the settling basin and in the plume that emanates from it. This region is shown on Figure 7-14, which is a contour map of total dissolved solids at the water table. Another region of elevated total dissolved solids is shown in the vicinity of the M-Area process area on Figure 7-14. Both of these regions are reflected in elevated concentrations of several individual analytes. 
The discussions that follow relate to the individual analytes.

\section{Aluminum}

Aluminum is a common rock forming element and concentrations of a few tenths of a part per million are common in natural water. Waters of low $\mathrm{pH}$ may have elevated concentrations of aluminum. Concentrations of aluminum above a part per million occured in wells AC-3B, MPT-1, MSB-11F, MSB-24, MSB-30C, MSB-34B, SRW-14B, SRW-15A in the spring of 1984. Of these AC-3B, MSB-24, and MSB-30C are associated with elevated $\mathrm{pH}$ which may indicate hydroxide arising from leaching of the cement sheath surrounding the well casing. With the exception of MSB-34B, SRW-14B, and SRW-15A, and the wells with elevated $\mathrm{pH}$, the other wells that show concentrations of aluminum above $1 \mathrm{mg} / \mathrm{L}$ are in the immediate vicinity of the settling basin.

\section{Ant imony}

The detection limit for antimony was 3 micrograms per liter. Only the concentration at well MSB-3A, ad jacent to the settling basin, is appreciably above the detection limit.

Arsenic

None of the 1984 analyses are above detectibility.

$\underline{\text { Barium }}$

The maximum contaminant level for community water systems is 1000 micrograms per liter (Environmental Protection Agency, 1977, p. 5). No analyses exceed this level. The median concentration for barium in public water supplies reported by Hem (1970) was 43 micrograms per liter. The concentration in M-Area monitor wells bracketed this median with samples from wells MPT-1, MSB-10A, $M S B-11 C, M S B-12 C$ and $D, M S B-16 A, M S B-22$, and MSB-34B appreciably above the median value. Barium is not used in M-Area operations, and does occur naturally in Aiken County.

\section{Beryllium}

In 1984 analyses, the only detectible beryllium occurred in MSB-22, adjacent to the M-Area sett 1 ing basin. 
Bromodichloromethane

There was no consistent detection of bromodichloromethane.

Cadmium

The drinking water limit for cadmium is 10 micrograms per liter (Environmental Protection Agency, 1977, p. 5). No concentrations have been found to exceed this concentration. A number of analyses have detection limits of 1 or 2 micrograms per liter, but for a number of samples, analytical methods were used that only had a detectibility limit of 20 micrograms per liter.

\section{Calcium}

Calcium is a major constituent of natural water. Natural calcium concentrations in water from the McBean sands in this area are about one ppm, whereas those from water in the $1 \mathrm{imy}$ beds of the McBean may be around $30 \mathrm{ppm}$ (Siple, 1967). In 1984, concentrations greater than about $30 \mathrm{ppm}$ occur in water from well MSB-22, MSB-23, MSB-24, MSB-3OC, and SRW-15A. Wells MSB-24 and MSB-30C have elevated pH which may indicate leaching of the cement sheath around the well casing.

Carbon, Dissolved Organic

Detectibility is generally $5 \mathrm{mg} / \mathrm{L}$. Only well, SRW-12A, is appreciably above this value.

\section{Carbon, Total Organic}

Most wells have total organic carbon concentration of less than $5 \mathrm{mg} / \mathrm{L}$, the usual detection limit. The only wells that are above this in the 1984 analyses are MSB-3A, adjacent to the basin, MSB-13B near Lost Lake and two wells at the Silverton Road waste site, $\mathrm{SRW}-12 \mathrm{~A}$ and $\mathrm{SRW}-13 \mathrm{C}$.

\section{Carbon Tetrachloride}

Carbon tetrachloride was detected in wells MSB-19C, MSB-24, $M S B-27 A$, MSB-31C, MSB-34B and $C$. None of these wells are near the settling basin. The highest concentration is in wells MSB-24 and $\mathrm{MSB}-34 \mathrm{~B}$ and $\mathrm{C}$. 
Chloride

The secondary drinking water limit for water supplies is $250 \mathrm{mg} / \mathrm{L}$ (Environmental Protection Agency, 1979). Chloride concentrations in samples from several wells around the Savannah River Laboratory seepage basin slightly exceed the median natural concentration of $2.7 \mathrm{mg} / \mathrm{L}$ (Siple, 1967, p. 83), reaching concentrations of $8.5 \mathrm{mg} / \mathrm{L}$ in well ASB-7. Also, chloride concentrations exceed this median in several wells around the M-Area settling basin and Lost Lake reaching a maximum of about $42 \mathrm{mg} / \mathrm{L}$ in well $\mathrm{MSB}-3 \mathrm{~A}$.

\section{Chlorobenzene}

Concentration of chlorobenzene is either below or only slightly above detectibility of 5 micrograms per liter except in well MSB-3A, adjacent to the M-Area settling basin; MSB-16C adjacent to process sewer line going to the settling basin; and MSB-24 in the M-Area process area.

\section{Chromium}

The drinking water standard for chromium is 50 micrograms per liter (Environmental Protection Agency, 1977, p. 5). Only concentrations at well MSB-24 in the M Area process area exceed this limit. Wells MSB-IIF and MSB-14B, near the settling basin show concentration of about 37 micrograms per liter. All other concentrations are either below detectibility or only slightly above.

\section{Conductivity}

Electrical conductivity is an indication of the concentration of dissolved ionic species in water. Values of over 100 micromhos per centimeter are common in natural water from the McBean and Congaree Formations. Wells AC-3B, MSB-9B, MSB-10C, MSB-13C, and MSB-30C have conductivities that exceed $100 \mu \mathrm{mho} / \mathrm{cm}$ but also have $\mathrm{pH}$ greater than 10 indicating that leaching of cement may be present. In addition, elevated conductivities occur in wells surrounding the M-Area settling basin; namely, wells MPT-1, MSB-3A, $4 A$, and $5 A, M S B-9 C, M S B-11 C, M S B-14 B$ and $C$, and $M S B-22$. Elevated conductivities that may reflect movement of groundwater are present in we $11 \mathrm{~s} M S B-10 C$, MSB-12B and $C, M S B-17 A$ and $B$, and RWM-3 (one of two demonstration recovery wells). Elevated conductivities at wells MSB-23, MSB-24, MSB-25, and MSB-34B may represent contributions of ionic species from other sources. 
Copper

The secondary drinking water standard for copper is 1000 micrograms per liter. No analyses exceed this level. The highest concentration of copper $(95 \mu \mathrm{g} / \mathrm{L})$ is found in well MSB-24.

\section{Cyanide}

The 1962 Public Health Service drinking water standard for cyanide was 200 micrograms per liter. All samples are below detectibility of 5 micrograms per liter except for wells MSB-9B and $13 B$, which are 21 and 57 micrograms per liter, respectively.

\section{Fluoride}

The maximum contaminant level of fluoride in community water systems ranges from 1400 to 2400 micrograms per liter depending on the temperature of the water (Environmental Protection Agency, 1977 , p. 5). Natural waters from the McBean and Congaree sands may range up to 300 micrograms per liter (Siple, 1967, p. 83). Only water from wells MPT-1, MSB-3, and MSB-22, adjacent to the settling basin appreciably exceeds the natural concentration of fluoride in the McBean and Congaree sands.

Grease and $0 i 1$

Detectability is generally $5 \mathrm{mg} / \mathrm{L}$. Only well ASB-4 is appreciably above this value.

Gross Alpha

The drinking water limit for gross alpha is 15 picocuries per liter (Environmental Protection Agency, 1977, p.7). Analyses were made on wells near the settling basin and pipe line, at the solvent tank and process area and downgradient from this area, and at the A-14 outfall. The drinking water limit was exceeded in three analyses from wells adjacent to the settling basin (MPT-1, MSB-3A,) and MSB-4A), but other analyses from the two wells showing the highest values (MPT-1 and MSB-3A) showed values less than the drinking water limit. The other well (MSB-4A) is 16 picocuries per liter only slightly above the drinking water standard. Several areas in the coastal plain of South Carolina have groundwaters that are naturally very high due to the presence of uranium and thorium minerals.

\section{Gross Bet a}

The same wells that showed elevated levels of gross alpha show elevated levels of gross beta.

$$
\text { 7-9 }
$$


Iron

The secondary drinking water standard for iron is 300 micrograms per liter (Environmental Protection Agency, 1979), however the maximum reported by Siple (1967, p. 83) from McBean and Congaree sands is 1840 micrograms per liter. The only 1984 analy$s$ is in the $A / M$ Area that approaches the concentration reported by Siple is from well SRW-16B. Some of the small variation in analytical results may be due to corrosion of the galvanized steel conductor pipe in the wells even though four well volumes of water are removed before sampling.

\section{Lead}

The drinking water standard for lead is 50 micrograms per liter (Environmental Protection Agency, 1977, p. 5). The only well that appreciably exceeds this value is MSB-24 in the M-Area process area. This well is high in $\mathrm{pH}(11.7)$ and is suspected of being influenced by cement. The high $\mathrm{pH}$ would solubilize lead that might be present. Several other wells barely exceed 50 micrograms per liter, namely MSB-2A next to the M-Area settling basin, MSB-20C which is half way between $M$ Area and the Silverton Road waste site, MSB-34B near the M-Area process area, and SRW-13C at the Silverton Road waste site. Thus there does not appear to be a consistent pattern of lead distribution. Corrosion from the galvanized steel conductor pipe which is present in all wells except MSB-1 through 8 (MSB-1A through 8A) may contribute to this inconsistent pattern. In addition, the 1983 samples were not filtered and so may contain suspended lead.

\section{Magnesium}

The magnesium concentrations in natural waters from McBean and Congaree sands may range up to 4000 micrograms per liter whereas those from 1 imy beds in those formations may range up to 9000 micrograms per liter (Siple, 1967, p.83). No analyses exceed these values. The only wells in the M-Area vicinity that approach these values are MPT-1, MSB-4A, MSB-9C, and MSBS-14B, all near the settling basin, and SRW-14B at the Silverton Road waste site.

\section{Manganese}

The secondary drinking water standards for manganese is 50 micrograms per liter (Environmental Protection Agency, 1979). The only wells that appreciably exceed this value are MPT-1, MSB-3A, MSB-11D and MSB-22, all near the M-Area settling basin, and SRW-14B and $16 \mathrm{~B}$ at the Silverton Road waste site. 
Mercury

The maximum contaminant level for mercury in community water systems is 2 micrograms per liter (Environmental Protection Agency, 1977 , P. 5). No wells exceed this value.

\section{Nickel}

The median concentration of nickel in North American Rivers was 10 micrograms per liter (Hem, 1970, p. 201). This value is only exceeded at we lls MPT-1, MSB-3A and 4A, MSB-9A, MSB-1 $1 D$ and $F, M S B-14 B$ and $C$, and MSB-22, all in the immediate vicinity of the M-Area settling basin. For some analyses, detection limits were 40 micrograms per liter.

\section{Nitrate}

Nitrate is reported in milligrams of nitrogen per liter, and as such the drinking water standard is $10 \mathrm{mg} / \mathrm{L}$ (Environmental Protection Agency, 1977 , p. 5). Because nitrate has been a significant constituent of the effluent discharge from M Area, a map of the concentration at the water table is presented in Figure 7-15. Elevated concentrations are principally confined to the immediate vicinity of the settling basin. Elevated concentrations also occur near the solvent tank (MSB-23), in the M-Area process area (MSB-24), and at well SRW-13C at the Silverton Road waste site. Slightly elevated concentrations occur at the MSB-12 and 17 sites.

\section{Nitrite}

No well shows a nitrite concentration consistently above detectibility.

pH

Natural waters from the McBean and Congaree sands range from 4.2 to 6.1 and from the limestones from 6.8 to 7.6 (Siple, 1967, p. 83). Thus, these waters are naturally acidic. The only well that produces water of $\mathrm{pH}$ less than 4 is MPT-1. On the other hand, several wells produce water of $\mathrm{pH}$ greater than 9. There is no pattern to these wells, and it is suspected that these elevated $\mathrm{pH}$ values may represent a leaching of the cement sheath surrounding the casing or an invasion of cement into the screen zone during the construction of the well. The wells with a $\mathrm{pH}$ above 9 are: $A C-3 B, M S B-9 B, M S B-10 C, M S B-13 B, M S B-20 C$, MSB-24, and MSB-30C. The correlation of several analytes with $\mathrm{pH}$ is shown on Table 7-3. 
Phenanthrene

No analysis for phenanthrene shows a value above detectibility of 1 microgram per liter.

\section{Phenol}

Phenol was found at levels slightly above detection limits at wells near the settling basin (MPT-1, MSB-3A, MSB-9C), near the pipe line (MSB-15A, MSB-16A), and in the process area (MSB-24).

\section{Phosphate}

Sources of phosphate are the dissolution of certain rocks, pollution from fertilizer or organic sewage, or the use of phosphates to break down the mud cake when attempting to develop a well. Normal well drilling practices at SRP do not include phosphate treatment; however, well MPT-1 was. difficult to develop and three treatments with sodium phosphate were used. The water presently produced from this well contains only $40 \mu \mathrm{g} / \mathrm{L}$, indicating most of the phosphate has been removed. Wells that have phosphate concentrations greater than $100 \mu \mathrm{g} / \mathrm{L}$ are MSB-9A, MSB-11A, B, and $F$, $M S B-14 C, M S B-25, M S B-31 C$ and SRW-14B. These wells do not fit into a readily recognizable pattern.

\section{$\underline{\text { Pot assium }}$}

Potassium is commonly a major constituent in natural water. Concentrations up to $5,000 \mu \mathrm{g} / \mathrm{L}$ are not unusual (Hem, 1970, p. 151), but potassium and sodium together from the McBean and Congaree sands rarely exceed 2400 micrograms per liter and from the limestones $19,000 \mu \mathrm{g} / \mathrm{L}$. The only wells that have concentrations of potassium that appreciably exceed $19,000 \mu \mathrm{g} / \mathrm{L}$ are MSB-13B and MSB-28A.

\section{Radium-226}

The drinking water standard for radium is 5 picocuries per liter, but natural waters from the Coastal Plain sediments show a large range in radium content. Of nine analyses of natural waters given by Siple $(1967$, p. 87$)$, five exceed the drinking water limit. The highest of these was 72 picocuries per liter. Radium analyses were made only at wells near the settling basin (MPT-1, MSB-3A and MSB-4A). The highest of these was 35 picocuries per 1 iter at MPT -1 . 
Radium, Total

Total radium was measured in 16 we $11 \mathrm{~s}$. The only analyses appreciably above 5 picocuries per liter were MPT-1 and MSB-3A.

\section{Selenium}

No selenium concentrations exceed detectability of 1 or 2 micrograms per liter. Maximum contaminant level for community water systems is 10 micrograms per liter (Environmental Protection Agency, 1977, p. 5).

\section{$\underline{\text { Silica }}$}

Silicon is second only to oxygen in abundance in the earth's crustal rocks. Silica is a common constituent of natural waters and concentrations commonly range from 1 to $30 \mathrm{mg} / \mathrm{L}$ (Hem, 1970, D. 109). Concentrations of silica in the analyses reported in Appendix $C$ range from 3 to $50 \mathrm{mg} / \mathrm{L}$ with no particular pattern apparent .

\section{Silver}

The maximum contaminant level for silver is 50 micrograms per liter (Environmental Protection Agency, 1977, p. 5). Additional analyses for silver are given in Appendix D. None of these analyses in either table exceed detectability except for well $M S B-5 A$ on 2-8-84, which was 3 micrograms per liter.

\section{Sodium}

As mentioned under the discussion of potassium, these two analytes combined rarely exceed $19 \mathrm{mg} / \mathrm{L}$ in 1 imestones of the McBean and Congaree Formations and 2.4 in the sands (Siple, 1967, p. 83). Wells whose analyses exceed $19 \mathrm{mg} / \mathrm{L}$ of sodium are in the vicinity of the settling basin and Lost Lake, such as MSB-3A, 4A, and 5A, $M S B-9 B$ and $C, M S B-13 B$ and $C$, MSB-14B, and MSB-22; we $11 \mathrm{~s} M S B-10 C$, MSB-12C, and MSB-17B also show elevated sodium concentrations. 


\section{Strontium}

Analyses of 200 underground and surface public water supplies in the U.S. had a median concentration of strontium of $100 \mu \mathrm{g} / \mathrm{L}$ (Hem, 1970, P. 197). Several wells in close proximity of the settling basin contain elevated concentrations of strontium for this area although only at concentrations about equal to the median for public drinking water mentioned above. These wells are MPT-1, MSB-1 IB and C, and MSB-22. Several wells with elevated pH, perhaps indicating leaching of cement, also show elevated strontium concentration. These wells are AC-3B, MSB-9B, MSB-10C, MSB-13B, MSB-20C, MSB-24, and MSB-3OC (Table 7-3). In addition, well MSB-23 at the solvent tank shows an elevated strontium concentration.

\section{Sulphate}

The secondary drinking water limit for sulphate is $250 \mathrm{mg} / \mathrm{L}$ (Environmental Protection Agency, 1979), but natural waters around SRP are commonly between <2 and $14 \mathrm{mg} / \mathrm{L}$ (Siple, 1967, P. 83). Well MSB-3A, adjacent to the settling basin, shows an elevated concentration of sulphate $(\sim 100 \mathrm{mg} / \mathrm{L})$. Well MSB-11A showed a level of $192 \mathrm{mg} / \mathrm{L}$ in 1984 analyses but less than $5 \mathrm{mg} / \mathrm{L}$ in 1983 . Well MSB-11A does not show elevated concentrations of other analytes, and it is suspected that the 1984 analysis is spurious.

\section{Surfactants}

The detection 1 imit of surfactants is 10 micrograms per 1 iter. Wells with detectible surfactants are $A C-1 A, A S B-9, M P T-1, M S B-3 A$, MSB-9A, $B$, and $C, M S B-10 A, M S B-11 D$ and $F, M S B-12 A$ and $D, M S B-13 B$, MSB-25A, MSB-28, and MSB-30C. Of these MPT-1, MSB-3A, MSB-9A, B, and $C$, and $M S B-11 D$ and $F$ are near the settling basin. Wells MSB-9B MSB-13B and MSB-3OC show elevated pH values (Table 7-3). But in general there seems to be no consistent pattern to the occurrence of surfactants, and reported levels are extremely low.

\section{Thallium}

Thallium is everywhere below the detectible limit of 2 or 3 $\mu g / L$ except at MSB-3A near the settling basin where it is $5 \mu \mathrm{g} / \mathrm{L}$. 
Total Dissolved Solids

The secondary drinking water standard for total dissolved solids is $500 \mathrm{mg} / \mathrm{L}$ (Environmental Protection Agency, 1979). Total dissolved solids reported by siple $(1967, p .83)$ in water from the $s$ ands of the McBean and Congaree Formations range from 20 to $29 \mathrm{mg} / \mathrm{L}$, but from the limestones they range from 75 to $192 \mathrm{mg} / \mathrm{L}$. The usual range of the wells reported in Appendix $C$ is from about 12 to about $100 \mathrm{mg} / \mathrm{L}$. Wells that are over $100 \mathrm{mg} / \mathrm{L}$ can be categorized into four groups -- (1) Those wells with high $\mathrm{pH}$ possibly indicating leaching of cement in the well annulus including $A C-3 B$, MSB-9B, MSB-10C, MSB-13B, MSB-24, MSB-30C; (2) wells in the immediate vicinity of the settling basin or Lost Lake including $M P T-1$, MSB-3A, 4A, and $5 A, M S B-9 B$ and $C, M S B-11 C$ and $D, M S B-13 B$, $M S B-14 B$ and $C$, and $M S B-22 ;$ (3) wells in the plume of groundwater movement from the basin including MSB-12B and $C$, MSB-17A and $B$, and (4) wells that represent sources of dissolved solids different from the settling basin including wells MSB-23 at the solvent tank and MSB-27 and RWM- 3 in the plume from the process area. Figure 7-14 shows concentration of total dissolved solids at the water table.

\section{Total Organic Halogen}

As might be expected, wells with elevated concentrations of degreaser solvents show elevated levels of total organic halogen. These include wells near the settling basin (MPT-1, MSB-3A, and MSB-1 IC and F), wells at the solvent tank and downgradient from the solvent tank (MSB-23 and 23B, MSB-26A, MSB-27A and RWM-2), wells in the process area (MSB-24A, MSB-34B and $C$, and $R W M-3$ ), and a well at the A-14 outfall (MSB-31C).

\section{Trans 1,2-Dichloroethylene}

Trans 1,2-dichloroethylene is a break-down product from trichloroethylene ( $\mathrm{Cl}$ ine and Viste, 1984). Thus it is not surprising that wells which show elevated concentrations of trichloroethylene also show elevated concentrations of trans 1,2dichloroethylene. These wells are ASB-8; MPT-1; MSB-1A, 2A, 3A, and 4A; MSB-9B and $C$; MSB-1OC; MSB-1 $1 C, D$, and $F$; $M S B-14 A$ and $B$; MSB-22; MSB-23B; MSB-26A; MSB-27A; MSB-28A; MSB-31C; MSB-34B and $C$; RWM-2 and 3 ; and $S R W-2 A$. 
Uranium

The common level of detectability for uranium in these analyses is 0.2 milligrams per liter. The only samples that exceed this value are from wells MSB-1LC and MSB-22 adjacent to the settling basin, and MSB-24 and RWM-3 in the process area.

\section{Vinyl Chloride}

The detection limit for vinyl chloride for the analyses given in Appendix $C$ is $10 \mathrm{~g} / \mathrm{L}$. The only detectible concentrations of vinyl chloride are at wells MSB-3A $(58 \mathrm{~g} / \mathrm{L})$ and $4 \mathrm{~A}(11 \mathrm{~g} / \mathrm{L})$, immediately adjacent to the settling basin. Since vinyl chloride has been reported as a possible degradation product from tetrachloroethylene and trichloroethylene through dichloroethylene, its presence is not surprising.

Zinc

The secondary drinking water limit for zinc is 5000 micrograms per liter (Environmental Protection Agency, 1979). The concentration of zinc in the 1984 analyses in Appendix $C$ have a range from 18 to $6,670 \mathrm{~g} / \mathrm{L}$ with no readily apparent pattern. Wells that have values above 5000 micrograms per liter are MSB-11D, 12A, 13C, 26A, $31 \mathrm{~A}$, and SRW-3C. Some variation in zinc may result from the presence of galvanized steel conductor pipes in the wells even though four well volumes of water were removed before sampling.

1,1-Dichloroethane; 1,1-Dichoroethylene; 1,1,2,2,-Tetrachloroethane; 1,2-Dichlorobenzene; and 1,4-Dichlorobenzene

Analyses for nearly all wells are below detectibility for these five organic compounds. Exceptions are that well MSB-3A, adjacent to the settling basin, has an elevated concentration of 1,1-dichloroethylene and that well MSB-4A, also adjacent to the

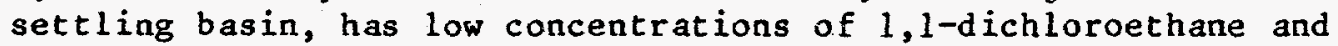
1,1- dichloroethylene. Wel1 MSB-9C, also adjacent to the basin, shows a barely detectible concentration of 1,1-dichloroethane. Well MSB-17B shows a detectible level of 1,1-dichloroethylene. Since dichloroethylene is a degradation product of trichloroethylene, its presence is not surprising. 


\subsection{Recovery Wells}

A second objective of the 30-day pumping test (discussed in Section 5.3.4) conducted from October 18 to November 17, 1982, was to obtain additional chemical data for design of a groundwater treatment process. For this, a total of 31 water samples were collected from the pumping well (MPT-1) during the 30-day test period. Table 7-4 presents the results of the organic analyses, temperature, $\mathrm{pH}$, and conductivity measurements taken in the field as well as the approximate elapsed time and the cumulative volume pumped at the time the sample was obtained. For each sample collection two vials were obtained for organic analys is by SRL. The results given on Table 7-4 are the average of the two analyses. As can be seen on Table 7-4, the analyses for both trichloroethylene and tetrachloroethylene are relatively constant, and approximately equal in concentration. The average trichloroethylene concentration for the 31 samples was $196 \mathrm{ppm}$ and the average concentration of tetrachloroethylene was 154 ppm producing an average total organic concentration of $350 \mathrm{ppm}$. No 1,1,1-trichloroethane was detected in any of the samples analyzed. The concentration of total organics in water later produced from MPT-1 and analysed by a different laboratory was about $115 \mathrm{ppm}$ as shown on Figure 7-16.

Measurements of $\mathrm{pH}$ obtained at the time the sample was collected range between 3.4 and 3.8 (Table $7-4$ ). The $\mathrm{pH}$ of natural groundwater from the McBean and Congaree sands is normally between 4.2 and 6.1 .

The temperature of the samples determined in the field at the time of collection ranged between $18^{\circ}$ and $20.5^{\circ} \mathrm{C}$, and electrical conductivity averaged about $500 \mathrm{micromhos} / \mathrm{cm}$, somewhat higher than the conductivity given in Appendix $C$ for this well.

Inorganic chemistry data were obtained on 10 of the 31 samples by Environmental and Chemical Sciences, Inc. under contract to SRL. The results of these analyses are presented on Table 7-5. Table 7-5 shows that the nitrate plus nitrite content, expressed as nitrogen, of the groundwater from MPT-1 is approximately $60 \mathrm{ppm}$. This is 70 percent higher than the value given in Appendix $C$. Conductivity measured is about 60 percent higher than the value given in Appendix C. Phosphate was 160 percent higher, but all other results, while not identical, are within the same range.

From the results of this pumping test, a pilot air stripper was designed to be operated with inlet feed from well MPT-1. Pilot operation of this system began in January 1983, and it has been operated virtually continuously since then through October 1984 . Analyses of the well discharge water for degreaser solvents are given on Figure 7-16. The total degreaser solvent concentration in water from well MPT-1 during the pilot operation was about $120 \mathrm{ppm}$, about one half the concentration observed during the pumping test. 
These differences could be partially due to the fact that 4 months elapsed between the pumping test and the pilot stripper operation and the analytical laboratories were changed from SRL to $320-M$. The purpose of operating the pilot system was to obtain design parameters with which to design a full scale unit. Degreaser solvent concentration in water is reduced in the stripper as a function of column length, air flow, and water flow. The effluent concentration in the final design of the remedial stripper will be less than $1 \mathrm{ppb}$.

Subsequent to tests on MPT-1, two additional demonstration recovery wells were drilled (RWM 2 and 3, Figure 7-17). Discharges from these two wells were pumped into a prototype air stripper (capacity $50 \mathrm{gpm}$ ) starting in the Fall of 1983 for further refinement of design parameters. Graphs of the concentration of degreaser solvents in these two wells are shown on Figures 7-18 and 7-19. The effluent concentration from the prototype stripper. was less than $1 \mathrm{ppb}$. By mid-October $1984,17,830$ pounds of degreaser solvent had been removed from well MPT-1 after pumping about 15 million gallons of water, 2,160 pounds from RWM-2 after pumping about 5.5 million gallons of water, and 9,290 pounds from RWM-3 after pumping about 10 million gallons. Thus almost 30,000 pounds of degreaser solvent had been removed from the groundwater as of mid-October 1984 .

From the data gathered from the operation of these three test recovery wells and their associated air strippers, an eleven-well recovery system was designed. The locations of these wells are shown on Figure 7-17. The system including the air stripper is designed for a capacity of 400-gallons per minute.

\subsection{Water Quality in the "Tuscaloosa" Pormation}

In March of 1983, two water supply wells in A/M Area were found to have low concentrations of degreaser solvents. Wells 905-53A and 20A (Figure 4-2) showed trichlorethylene concentrations up to $26 \mathrm{ppb}$ and $8 \mathrm{ppb}$, respectively. As a result of these analyses wells $905-53 \mathrm{~A}$ and $20 \mathrm{~A}$ were taken out of service.

Well cluster MSB-34 was installed 250 feet from well 905-53A and showed degreaser solvent concentrations in water ranging from about $53,900 \mathrm{ppb}$ at the water table to $642 \mathrm{ppb}$ near the base of the Tertiary: sediments (Appendix B). The degreaser solvents in the Tertiary sediments in the immediate vicinity of well $53 \mathrm{~A}$ are probably the source of these substances in water produced from this "Tuscaloosa" well. 
A series of tests were made on well 905-53A to determine the conditions in the well itself. The well is 670 feet deep and screened intermittently from 387 to 670 feet. The results of these tests were:

1. A TV camera survey indicated no gross casing breaks.

2. Packer tests indicated that the casing does leak (the possibility always exists of a poor packer setting that might negate this conclusion).

3. A cement bond $\log$ indicated that there were extensive areas where the cement sheath around the casing, whose purpose is to seal the casing to the ground, was not bonded to the casing. Such areas of poor bond could provide avenues for contaminated water from the Tertiary sediments to migrate directly to the screened sections of the Tuscaloosa.

4. A vertical water velocity survey showed that water inside the screened zone moves from about 430 feet down to about 640 feet at a velocity of about $7 \mathrm{feet} / \mathrm{minute}$ or at about $28 \mathrm{gallons}$ per minute in the 10-inch casing. This water movement has gone on continuously since the pump was shut down in April 1983.

5. Samples collected by a thief sampler every 50 feet from a depth of 180 feet (water level) to 680 feet showed tritium concentrations in all samples to be less than the detectable level of 0.02 picocuries per gram (20 picocuries per liter). All tetrachloroethylene concentrations on the same set of samples were less than $1 \mathrm{ppb}$. Trichloroethylene concentrations in the same set of samples were less than 1 ppb except for the samples at 430 and 480 feet which were 3 and $4 \mathrm{ppb}$, respectively.

The conclusion from these tests is that there is a strong probability that the presence of degreaser solvents in water from the "Tuscaloosa" is very localized and occurred only at the site of the water production well.

Even before the degreaser solvents were discovered in 905-53A, three monitoring wells (MSB-23A, 30A, and $31 \mathrm{~A}$ ) had been drilled (February 1983) to explore the potential for movement of degreaser solvents vertically from the Tertiary sediments through the Ellenton into the "Tuscaloosa". No solvents had been found in any of these wells. Subsequent to the discovery of the solvents in the two production wells, four more "Tuscaloosa" monitoring wells were drilled (MSB-12TA, 12TB, 34TA, and 34TB). 
The locations of the "Tuscaloosa" monitoring wells are shown on Figure 4-2, and the total depth and screened interval for each well are tabulated on Table 4-2. The first "Tuscaloosa" monitoring well (MSB-23A) was installed in the vicinity of the solvent storage $t$ ank at Building $321-M$ in an area of elevated concentrations of degreaser solvents in the Tertiary sediments. The second well (MSB-30A) was drilled approximately 2000 feet west of MSB-23A between $M$ Area and the plant boundary. A third "Tuscaloosa" well (MSB-31A) was installed adjacent to the A-14 sewer outfall leading to Tims Branch. Two "Tuscaloosa" wells (MSB-12TA and 12TB) were installed at existing well cluster site MSB-12 southwest of the M-Area basin. Well cluster MSB-34 was installed as close as reasonably possible to production well 905-53A to assess the source of the degreaser solvents in this supply well. This cluster was located approximately 250 feet from Well 905-53A in the direction of $M$ Area. The cluster consists of three Tertiary wells and two "Tuscaloosa" wells in order to obtain vertical head data as well as water quality data. The results of the chemical analyses from the "Tuscaloosa" monitoring wells are given in Appendices B and $C$.

During 1983 no degreaser solvents were found in any "Tuscaloosa" monitoring well (Appendix B), and it was concluded that the low concentrations at the production wells were caused by (1) inadequate seals by the cement sheath between the casing and the ground opposite the Tertiary sediments and (2) the increased head differential between the water in the Tertiary and that in the "Tuscaloosa" caused by the drawdown at the production well. Although the concentrations of degreaser solvents are quite high in the Tertiary sediments at the solvent tank (MSB-23, Figure 7-1), the levels in soil samples from the Ellenton Formation attenuate rapidly with depth. The concentration at the top of the Ellenton is $268 \mathrm{ppb}$ and attenuates to $10 \mathrm{ppb}$ (Table 7-6) at the bottom of the "Tuscaloosa" clay, which underlies the Ellenton. (Editorial Note: During the drilling of a replacement well for MSB-23A in July 1985, 18 soil samples were collected in the Ellenton and upper "Tuscaloosa" Formations between depths of 250 and $325 \mathrm{ft}$. Analyses of these samples show less than $10 \mathrm{ppb}$ total chorocarbons, the detection limit, for all samples.)

In 1984 (Appendix B) positive results for trichloroethylene began to appear in the fluid samples of well MSB-23A. There is, however, a very definite possibility that the cement sheath between the casing and the ground at this well may also be imperfect even though the analysis given in Appendix $c$ is not high in the constituents listed on Table 7-3. Other analyses from this well show that $\mathrm{pH}$ is highly dependant on the amount of water pumped prior to sampling. 
It appears that it simply took over a year for the solvents to migrate through the fine cracks or poor bonding of the cement sheath. It is planned to plug this well and install another one. (Editorial Note: A replacement well was installed in July 1985.) No degreaser solvents have been found in the "Tuscaloosa" at any other monitor well location during the first half of 1984. Although some analyses in Appendix B show slight positive results, these are not consistent and subsequent analyses show negative results. These are, therefore, thought to be spurious analyses. Thus, it appears that prevasive contamination of the "Tuscaloosa" from the Tertiary plume has not occurred. It also appears that, based on data collected up to October 1984, where degreaser solvents are present in "Tuscaloosa" water, it is related to well construction. (Editorial Note: In the drilling program of the Fall of 1984, 14 additional "Tuscaloosa" monitoring wells were drilled. Only one of these wells (MSB-37TA) showed chlorocarbons appreciably above the detectable limit. A faulty cement seal can be ruled out as the cause for this concentration because concentrations in the Tertiary sediments above are lower. The cause of the presence of chlorocarbons in the "Tuscaloosa" at this location is being vigorously investigated.)

\subsection{Movement of Degreaser Solvents}

Results of analyses for degreaser solvents are quite variable. Figures 7-20 to 7-24 show time/concentration graphs for water from wells in clusters MSB-9, 14, and 19, and wells MSB-26A and 28A. These plots are somewhat typical for the variability of analyses at other well clusters. From these graphs it is difficult to draw definitive conclusions about degreaser solvent movement. More analyses to establish time trends are required.

However, some conclusions can be drawn about degreaser solvent movement from the present shape of the plume. Figure 6-1 shows the potential or suspected distribution of sources. The principal sources seem to be at the solvent tank, the settling basin, and the A-14 outfall.

These sources are reflected on Figure $7-11$ as places where the water table concentrations of over $10,000 \mathrm{ppb}$ of trichloroethylene plus tetrachloroethylene occur. From these locations the solvents move in the direction of the groundwater gradient which is downward as well as laterally. Thus on Figure 7-12, which is a horizontal slice through the ground at a level about 60 to 100 feet below the water table, two lobes of solvents appear that are not present in the concentration map of the water table. 
The lobe of elevated concentrations centered in the vicinity of the solvent tank and drum storage locations matches a potentiometric lobe in the water table. Currently, there are insufficient data to determine if this piezometric lobe is also present at an elevation of 60 to 100 feet below the water table. The vertical descent of degreaser solvents in this lobe is shown on Figure 7-9.

The second lobe of solvents in the vicinity of the settling basin (Figure 7-12) also generally follows the gradient of the water table (Figure 5-3) or that of the zone 60 to 100 feet below the water table (Figure 5-4) except that the lobate shape is accentuated by the low concentrations at MSB-10. The effect of these low concentrations at MSB-10 also influences the shape of the average concentration map (Figure 7-7). (Editorial Note: Subsequent studies of the geology of this area indicate that well MSB-1OB may be in a sand that is not correlative with other sands in this zone.)

The degreaser solvents in the deepest Tertiary zone (Figure 7-13) appear to be not as high in concentration nor as extensive as the middle zone (Figure 7-12), although mapping control on the deepest zone is not as great as on the middle zone. Nevertheless the areas of highest concentration in the deepest Tertiary zone are those directly under the major surface sources of degreaser solvents.

\subsection{Conclusions}

Degreaser solvents have entered the groundwater in the Tertiary sediment from several surface sources. The probable primary surface sources are the M-Area settling basin, the solvent storage tank area, and the A-14 sewer outfall (Figure 6-1). Other possible sources are the pipeline leading to the settling basin and the process area including a discontinued solvent drumming facility. The maximum concentration of degreaser solvents, 542 ppm, occurs at the water table (Figure 7-11) under the settling basin. High concentrations also occur at the water table under the other surface sources. At a greater depth (about 75 feet below the water $t a b l e)$, the maximum concentration has decreased to $61 \mathrm{ppm}$ but the plume occupies a larger area than it does at the water table (Figure 7-12). Near the base of the Tertiary sediments ( 120 feet below the water $t a b l e)$ both the maximium concentration and the area of the plume have decreased greatly, being restricted to the general area beneath the surface sources (Figure 7-13). 
Although low concentrations of degreaser solvents have been detected from production and monitoring wells that are screened in the "Tuscaloosa" Formation, there is evidence in each case of a faulty well seal. Based on the evidence to date, there does not appear to be a prevasive passage of degreaser solvents even at low concentrations into the "Tuscaloosa" Formation. (Editorial Note: As mentioned in the editorial note at the end of Section 7.4, well MSB-37TA indicates chlorocarbons in the "Tuscaloosa" that have not come through a faulty well seal.)

Plumes of elevated concentrations of total dissolved solids (Figure 7-14) occur in the vicinity of the M-Area settling bas in and in the M-Area process area (vicinity of Building 321-M). These same two areas are underlain by plumes of elevated nitrate concentrations at the water table (Figure 7-15). In the wells immediately adjacent to the M-Area settling basin there are somewhat elevated concentrations of aluminum, chloride, fluoride, magnesium, manganese, nickel, sodium, strontium, and trans 1,2-dichloroethylene. The significance of these findings is not clear at this time but is being investigated as part of the ongoing groundwater assessment program.

Additional investigations of the hydrogeology and the contaminant plume are presently being vigorously pursued. In addition, the full-scale remedial action program ( $400 \mathrm{gpm}$ air stripper and 11 recovery wells) is scheduled to begin in April 1985. (Editorial Note: The air stripper started operation on April 19, 1985 and the entire system was operational on September 9, 1985.) 
References For Chapter 7

Christensen, E. J. and D. E. Gordon, 1983. Technical Summary of

Groundwater Quality Protection Program at Savannah River Plant, Vo1. 1, DPST-83-829, E. I. du Pont de Nemours and Company, Savannah River Laboratory, Aiken, SC.

Cline, P. V. and D. R. Viste, 1984. Migration and Degradation Patterns of Volatile Organic Compounds, in the 5th National Conference on Hanagement of Dncontrolled Hazardoas Waste Sites, November 7-9, 1984, Hazardous Materials Control Research Institute, Silver Spring, MD.

Environmental Protection Agency, 1977. National Interim Primary Drinking Water Regulations, U.S. Environmental Protection Agency EPA-570/9-76-003.

Environmental Protection Agency, 1979. National Secondary Drinking Water Regalations, Code of Federal Regulations 40 CFR 143.

Gordon, D. E., 1982. Preliminary Technical Data Summary, M-Area Groundwater Cleanup Facility, DPSTD-82-69, E. I. du Pont de Nemours and Company, Savannah River Laboratory, Aiken, SC.

Hem, J. D., 1970. Study and Interpretation of the Chemical Characteristics of Natural Hater, U.S. Geological Survey Water Supply Paper 1473, 363 pp.

Siple, G. E., 1967. Geology and Groundwater of the Savannah River Plant and Vicinity South Carolina, U.S. Geological Survey Water Supply Paper 1841, 113 pp. 
TABLE 7-1

Estimate of Inventory of Degreaser Solvents in the Saturated Zone

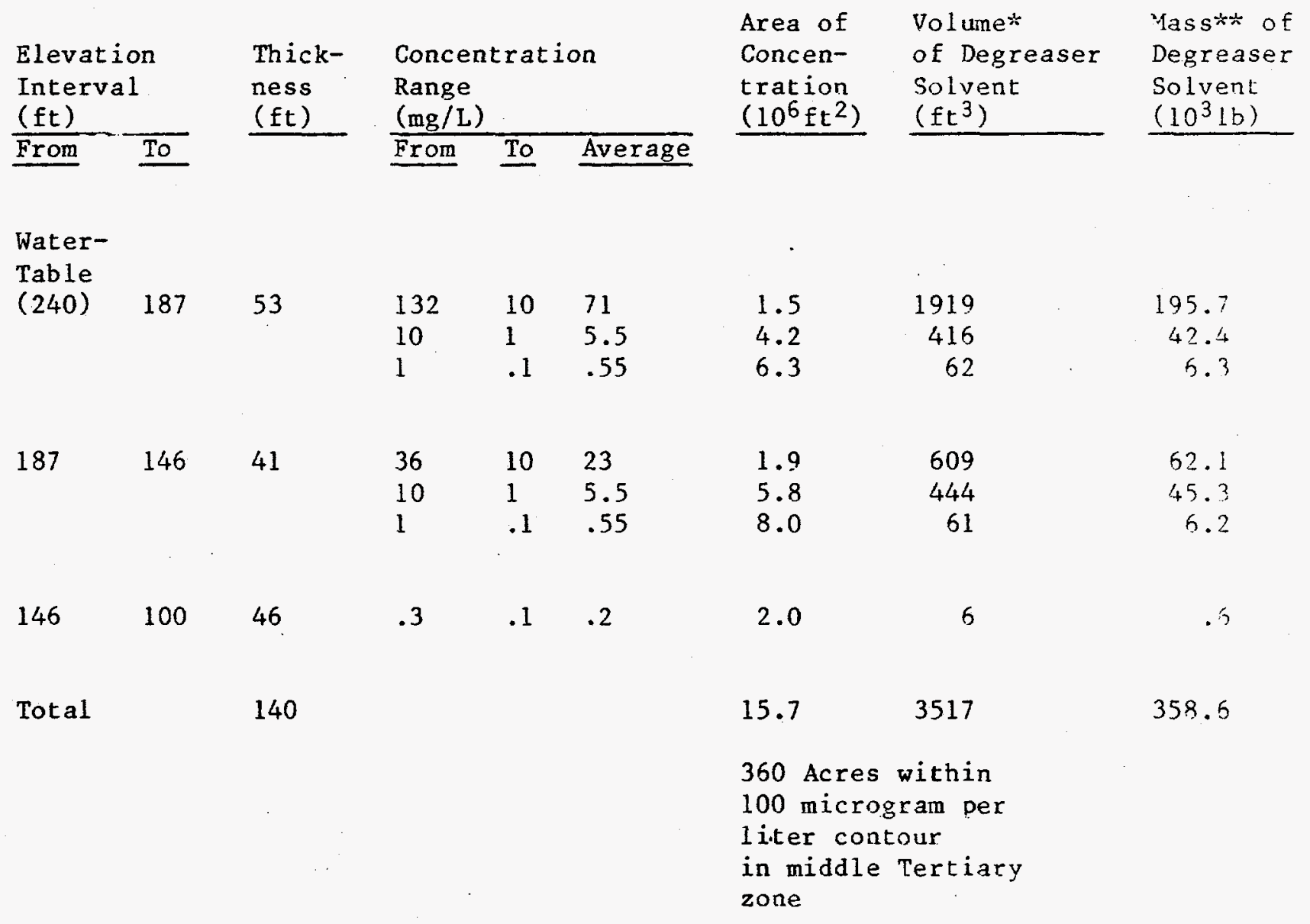

* A soil total porosity of 34 percent is used (Table 5-1)

** A density $102 \mathrm{lb} / \mathrm{ft}^{3}$ is used (Gordon, 1982). 
TABLE 7-2

Elements, Compounds, and Properties for Which Analyses were Made on Samples of Water Collected from Monitoring Wells

(Results for those preceeded by an astrisk are not reported in Appendix $\mathrm{C}$, and the reason for not reporting them is given in the introduction to the appendix.)

\section{Metals}

Antimony

Arsenic

Beryllium

Cadmium

Chromium

Copper

Lead

\section{Organics}

*Acrolein

*Acrylonitrile

*Benzene

*Bis (2-ethylhexyl) Phthalate

Bromodich lorome thane

*Bromo form

*Bromomethane

Carbon Tetrachloride

Chlorobenzene

*Chloroethane

*2-Chloroethylvinyl Ether

*Chloroform

*Chlorome thane

Cyanide

*D ibromochlorome thane

1,2-Dichlorobenzene

1,4-Dichlorobenzene

1,1-Dichloroethane
Mercury

Nickel

Selenium

Silver

Thallium

Uranium

Zinc 
TABLE 7-2, Contd

Cations

Aluminum
Barium
Calcium
Iron
Magnesium
Manganese
Potassium
Sodium
Strontium

Anions

Chloride

Fluoride

Nitrate

Nitrite

Phosphate

Sulphate

* Sulphide

\section{Radioactivity}

Gross Alpha

Gross Beta

Radium 226

Radium Total

\section{Pesticides}

*Endrin

*Lindane

* Methoxychior

*Silvex

*Toxaphene

\section{Properties}

Conductivity

$\mathrm{pH}$

*Color

*Corrosivity

* Fecal Coloform

*Odor

*Turbidity
Other

Carbon, Dissolved organic

Carbon, Total Organic

Grease and $0 i 1$

Silica

*Silicon

Surfactants

Total Dissolved Solids

Total Organic Halogens 
TABLE 7-3

Wells Where Leaching of Cement May Be Influencing the Concentration of Analytes

\begin{tabular}{|c|c|c|c|c|c|c|}
\hline We 11 & $\mathrm{pH}$ & $\begin{array}{l}\text { conductivity } \\
(\mu \mathrm{mho} / \mathrm{cm})\end{array}$ & $\begin{array}{l}\text { Aluminum } \\
(\mathrm{mg} / \mathrm{L}) \\
\end{array}$ & $\begin{array}{l}\text { Calcium } \\
(\mathrm{mg} / \mathrm{L}) \\
\end{array}$ & $\begin{array}{l}\text { Strontium } \\
(\mu \mathrm{g} / \mathrm{L}) \\
\end{array}$ & $\begin{array}{l}\text { Total } \\
\text { Dissolved } \\
\text { Solids } \\
\text { (mg/L) } \\
\end{array}$ \\
\hline $\begin{array}{l}\text { perspective } \\
\text { value }\end{array}$ & $4.2-6.1$ & 100 & $\sim 1$ & $1-30$ & 110 & 100 \\
\hline$A C-3 B$ & 10.8 & 224 & 2.5 & 33 & 105 & 142 \\
\hline$M S B-9 B$ & 10.4 & 260 & $<.3$ & 10 & 126 & 120 \\
\hline$M S B-10 C$ & 9.4 & 215 & $<.3$ & 32 & 497 & 182 \\
\hline $\mathrm{MSB}-13 \mathrm{~B}$ & 9.5 & 213 & $<.3$ & 8 & 168 & 160 \\
\hline$M S B-20 C$ & 10.3 & 147 & .7 & 40 & 106 & 78 \\
\hline$M S B-24$ & 11.7 & 960 & 5.5 & 115 & 408 & 322 \\
\hline$M S B-30 C$ & 10.5 & 175 & 1.6 & 40 & 496 & 100 \\
\hline
\end{tabular}


TABLE 7-4

Analyses of Degreaser Solvents, pH, Temperature, and Conductivity During 30-Day Pumping Test on MT-1 (10-18-82 to 11-17-82)

\begin{tabular}{|c|c|c|c|c|c|c|c|c|}
\hline $\begin{array}{l}\text { Sample } \\
\text { No. }\end{array}$ & $\begin{array}{l}\text { Approx. } \\
\text { Cumulative } \\
\text { Gal Pumped }\end{array}$ & $\begin{array}{l}\text { Approx. } \\
\text { Cumulat ive } \\
\text { Iime }\end{array}$ & $\begin{array}{l}\text { Average } \\
\text { Trichloro- } \\
\text { ethylene } \\
\text { (ppm) }\end{array}$ & $\begin{array}{l}\text { Average } \\
\text { Tetrachloro- } \\
\text { ethylene } \\
\text { (ppm) } \\
\end{array}$ & $\begin{array}{l}\text { Average } \\
\text { Total } \\
\text { Organics } \\
\text { (ppm) } \\
\end{array}$ & $\mathrm{pH}$ & $\begin{array}{l}\text { Temp } \\
(" \mathrm{C}) \\
\end{array}$ & $\begin{array}{l}\text { Conduct ivlty } \\
(\mu \mathrm{mho} / \mathrm{cm})\end{array}$ \\
\hline 1 & 1800 & $1 \mathrm{hr}$ & 191 & 208 & 399 & - & - & - \\
\hline 2 & 3600 & $2 n r$ & 152 & 140 & 292 & 3.80 & 20.0 & - \\
\hline 3 & 5300 & $4 h r$ & 164 & 150 & 314 & 3.75 & 19.2 & - \\
\hline 4 & 10600 & $6 \mathrm{hr}$ & 162 & 162 & 324 & 3.75 & 19 & - \\
\hline 5 & 15900 & $9 \mathrm{hr}$ & 165 & 147 & 312 & 3.80 & 18 & - \\
\hline 6 & 21550 & $13 \mathrm{hr}$ & 139 & 126 & 265 & 3.40 & 19 & - \\
\hline 7 & 32200 & $19 \mathrm{hr}$ & 155 & 144 & 299 & 3.75 & 19.5 & $=$ \\
\hline 8 & 43000 & $24 \mathrm{hr}$ & 170 & 150 & 320 & 3.65 & 20.5 & - \\
\hline 9 & 64400 & $35 \mathrm{hr}$ & 162 & 139 & 301 & 3.60 & 19.2 & - \\
\hline 10 & 85700 & $48 \mathrm{hr}$ & 164 & 135 & 299 & 3.60 & 20 & - \\
\hline 11 & 107200 & $59 \mathrm{hr}$ & 111 & 102 & 213 & 3.60 & 20 & - \\
\hline 12 & 128950 & $72 \mathrm{hr}$ & 132 & 114 & 246 & 3.60 & 20 & - \\
\hline 13 & 162300 & $90 \mathrm{hr} 10 \mathrm{~min}$ & 138 & 126 & 264 & 3.50 & 18.5 & - \\
\hline 14 & 181200 & $101 \mathrm{hr} 30 \mathrm{~m} \mathrm{n}$ & 210 & 170 & 380 & 3.50 & 19 & - \\
\hline 15 & 207600 & $116 \mathrm{hr} 10 \mathrm{~min}$ & 211 & 172 & 383 & 3.55 & 19 & - \\
\hline 16 & 252600 & $141 \mathrm{hr} 50 \mathrm{~min}$ & 202 & 159 & 361 & 3.60 & 19 & - \\
\hline 17 & 292600 & $165 \mathrm{hr}$ & 132 & 158 & 290 & 3.70 & 19 & - \\
\hline 18 & 338000 & $190 \mathrm{hr}$ & 189 & 199 & 388 & 3.70 & 19 & - \\
\hline 19 & 385350 & $216 \mathrm{hr}$ & 191 & 173 & 364 & 3.75 & 19.5 & 470 \\
\hline 20 & 427500 & $239 \mathrm{hr} 15 \mathrm{~min}$ & 219 & 173 & 392 & 3.45 & - & 480 \\
\hline 21 & 511250 & $284 \mathrm{hr} 50 \mathrm{~min}$ & 324 & 256 & 580 & 3.40 & 19.5 & 550 \\
\hline 22 & 551700 & $307 \mathrm{hr}$ & 166 & 84 & 250 & 3.70 & 19 & 550 \\
\hline 23 & 598600 & $334 \mathrm{hr}$ & 185 & 124 & 309 & 3.70 & 19.5 & 525 \\
\hline 24 & 671550 & $380 \mathrm{hr} 55 \mathrm{~min}$ & 237 & 160 & 397 & 3.50 & 19.5 & 520 \\
\hline 25 & 729700 & $432 \mathrm{hr} 30 \mathrm{~min}$ & 281 & 190 & 471 & 3.45 & 19 & 475 \\
\hline 26 & 806300 & $475 \mathrm{hr} 35 \mathrm{~min}$ & 330 & 209 & 539 & 3.55 & 18.5 & 475 \\
\hline 27 & 902950 & $529 \mathrm{hr}$ & 262 & 149 & 411 & 3.40 & 19.5 & 420 \\
\hline 28 & 985100 & $575 \mathrm{hr}$ & 216 & 130 & 346 & 3.50 & 19 & 490 \\
\hline 29 & 1072750 & $621 \mathrm{hr} 40 \mathrm{~min}$ & 245 & 143 & 388 & 3.60 & 19 & 475 \\
\hline 30 & 1164300 & $671 \mathrm{hr} 55 \mathrm{~min}$ & 230 & 134 & 364 & 3.80 & 19 & 490 \\
\hline 31 & 1247800 & $717 \mathrm{hr} 35 \mathrm{~min}$ & 250 & 136 & 386 & 3.60 & 18 & 465 \\
\hline
\end{tabular}


TABLE 7-5

Analyes of Inorganic Chenistry of Selected Water Samples from MPT-1 During 30-Day Puping Test

(see Table 7-4 for identification of sample numbers)

\begin{tabular}{|c|c|c|c|c|c|c|c|}
\hline Sample & $\mathrm{pH}$ & $\begin{array}{l}\text { ORP* } \\
(\mathrm{mV})\end{array}$ & $\begin{array}{l}\text { Cond } \\
(\mu \mathrm{mho} / \mathrm{cm})\end{array}$ & $\begin{array}{l}\mathrm{NO}_{2}+\mathrm{NO}_{3}=\mathrm{N} \\
(\mathrm{mg} \mathrm{N} / \mathrm{L}) \\
\end{array}$ & $\begin{array}{l}\text { Chloride } \\
(\mathrm{mg} / \mathrm{L})\end{array}$ & $\begin{array}{l}\mathrm{SO}_{4} \\
\left.\text { (mg } \mathrm{SO}_{4} / \mathrm{L}\right) \\
\end{array}$ & $\begin{array}{l}\text { Ortho } P \\
(\mathrm{mg} P / \mathrm{L}) \\
\end{array}$ \\
\hline 4 & 3.38 & 490 & 450 & 54.5 & 5.00 & 0.4 & 0.141 \\
\hline 8 & 3.32 & 410 & 460 & 59.0 & 4.50 & 0.2 & 0.105 \\
\hline 14 & 3.30 & 410 & 460 & 57.5 & 4.25 & $<0.2$ & 0.132 \\
\hline 17 & 3.32 & 410 & 420 & 56.0 & 4.25 & $<0.2$ & 0.124 \\
\hline 20 & 3.35 & 415 & 465 & 67.5 & 4.50 & $<0.2$ & 0.141 \\
\hline 22 & 3.38 & 490 & 500 & 63.0 & 4.50 & $<0.2$ & 0.136 \\
\hline 24 & 3.39 & 480 & 495 & 65.5 & 4.50 & $<0.2$ & 0.121 \\
\hline 26 & 3.42 & 480 & 420 & 51.5 & 4.00 & $<0.2$ & 0.105 \\
\hline 28 & 3.40 & 480 & 480 & 62.0 & 4.00 & $<0.2$ & 0.116 \\
\hline 31 & 3.38 & 420 & 425 & 62.0 & 4.00 & $<0.2$ & 0.106 \\
\hline
\end{tabular}

*Oxidation - Reduction potential measured at $25^{\circ} \mathrm{C}$, referenced to hydrogen electrode

\begin{tabular}{|c|c|c|c|c|c|c|c|c|c|}
\hline Sample & $\begin{array}{l}\mathrm{Al} \\
(\mathrm{mg} / \mathrm{L})\end{array}$ & $\begin{array}{l}\mathrm{Ca} \\
(\mathrm{mg} / \mathrm{L})\end{array}$ & $\begin{array}{l}\mathrm{Cu} \\
(\mathrm{mg} / \mathrm{L}) \\
\end{array}$ & $\begin{array}{l}\mathrm{Fe} \\
(\mathrm{mg} / \mathrm{L}) \\
\end{array}$ & $\begin{array}{l}\mathrm{X} \\
(\mathrm{mg} / \mathrm{L})\end{array}$ & $\begin{array}{l}\text { (mg/L) } \\
(m, ~\end{array}$ & $\begin{array}{l}\mathrm{Na} \\
(\mathrm{mg} / \mathrm{L})\end{array}$ & $\begin{array}{l}\mathrm{Ni} \\
(\mathrm{mg} / \mathrm{L}) \\
\end{array}$ & $\begin{array}{l}\mathrm{Zn} \\
(\mathrm{mg} / \mathrm{L}) \\
\end{array}$ \\
\hline 4 & 10.6 & 35.3 & $<0.005$ & 0.091 & 0.94 & 7.01 & 10.6 & 0.09 & 0.10 \\
\hline 8 & 10.7 & 36.1 & $<0.005$ & 0.085 & 1.14 & 7.40 & 10.9 & 0.16 & 0.11 \\
\hline 14 & 9.3 & 36.1 & $<0.005$ & 0.077 & 1.06 & 8.56 & 12.1 & 0.09 & 0.10 \\
\hline 17 & 7.6 & 35.3 & $<0.005$ & 0.064 & 0.98 & 7.96 & 9.7 & 0.10 & 0.09 \\
\hline 20 & 8.0 & 42.5 & $<0.005$ & 0.063 & 1.16 & 9.98 & 11.8 & 0.11 & 0.10 \\
\hline 22 & 7.5 & 43.9 & $<0.005$ & 0.048 & 1.19 & 10.23 & 11.3 & 0.09 & 0.09 \\
\hline 24 & 7.6 & 41.6 & $<0.005$ & 0.053 & 1.18 & 10.11 & 11.0 & 0.06 & 0.09 \\
\hline 26 & 5.9 & 35.9 & $<0.005$ & 0.040 & 1.04 & 9.10 & 8.8 & 0.08 & 0.06 \\
\hline 28 & 6.7 & 41.4 & $<0.005$ & 0.041 & 1.22 & 10.76 & 13.8 & 0.11 & 0.07 \\
\hline 31 & 5.9 & 44.3 & $<0.005$ & 0.037 & 1.21 & 11.04 & 11.6 & 0.09 & 0.07 \\
\hline
\end{tabular}


TABLE 7-6

Results of soil Analyses for Degreaser Solvents in the

Ellenton Formation at Monitor Well uSB-23A (Figure 7-1)

\begin{tabular}{|c|c|c|c|c|}
\hline $\begin{array}{l}\text { Depth } \\
\text { (ft). }\end{array}$ & $\begin{array}{l}1,1,1- \\
\text { Trichloroethane }\end{array}$ & Trichloroet hylene & Tet rachloroet hy lene & $\begin{array}{l}\text { Total } \\
\text { Degreaser } \\
\text { Solvents } \\
\end{array}$ \\
\hline 250 & $<10$ & $<10$ & 54 & 54 \\
\hline 255 & $<10$ & 97 & 171 & 268 \\
\hline 278 & $<10$ & 32 & 21 & 53 \\
\hline 281 & $<10$ & 45 & 40 & 85 \\
\hline 283 & $<10$ & 45 & 35 & 80 \\
\hline 293 & $<10$ & 44 & 36 & 80 \\
\hline 298 & $<10$ & 23 & 22 & 45 \\
\hline 308 & $<10$ & $<10$ & 10 & 10 \\
\hline
\end{tabular}




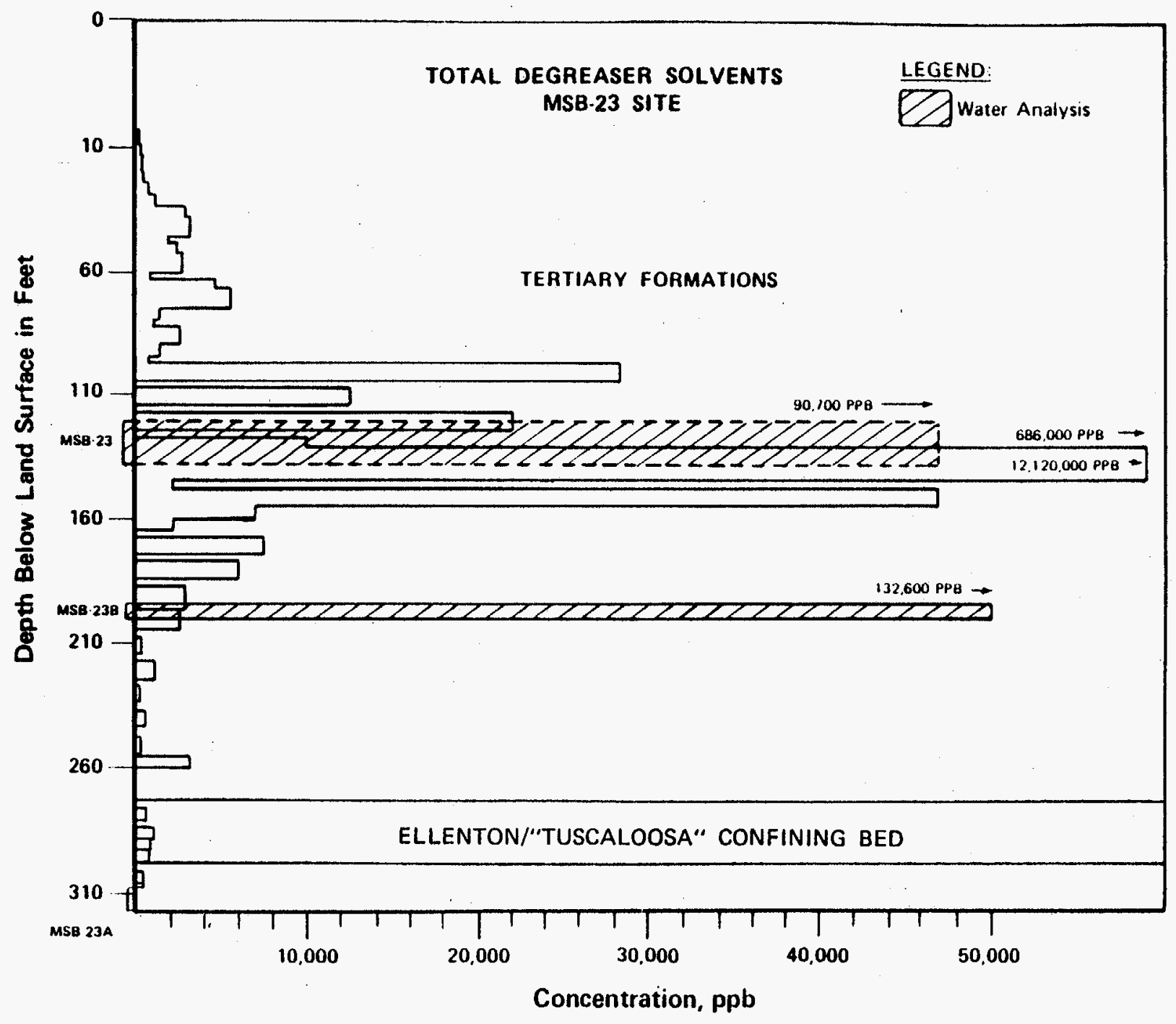

FIGURE 7-1. Concentration Profiles of Total Degreaser Solvents From Soil and Hater Samples at Well Cluster MSB-23. 


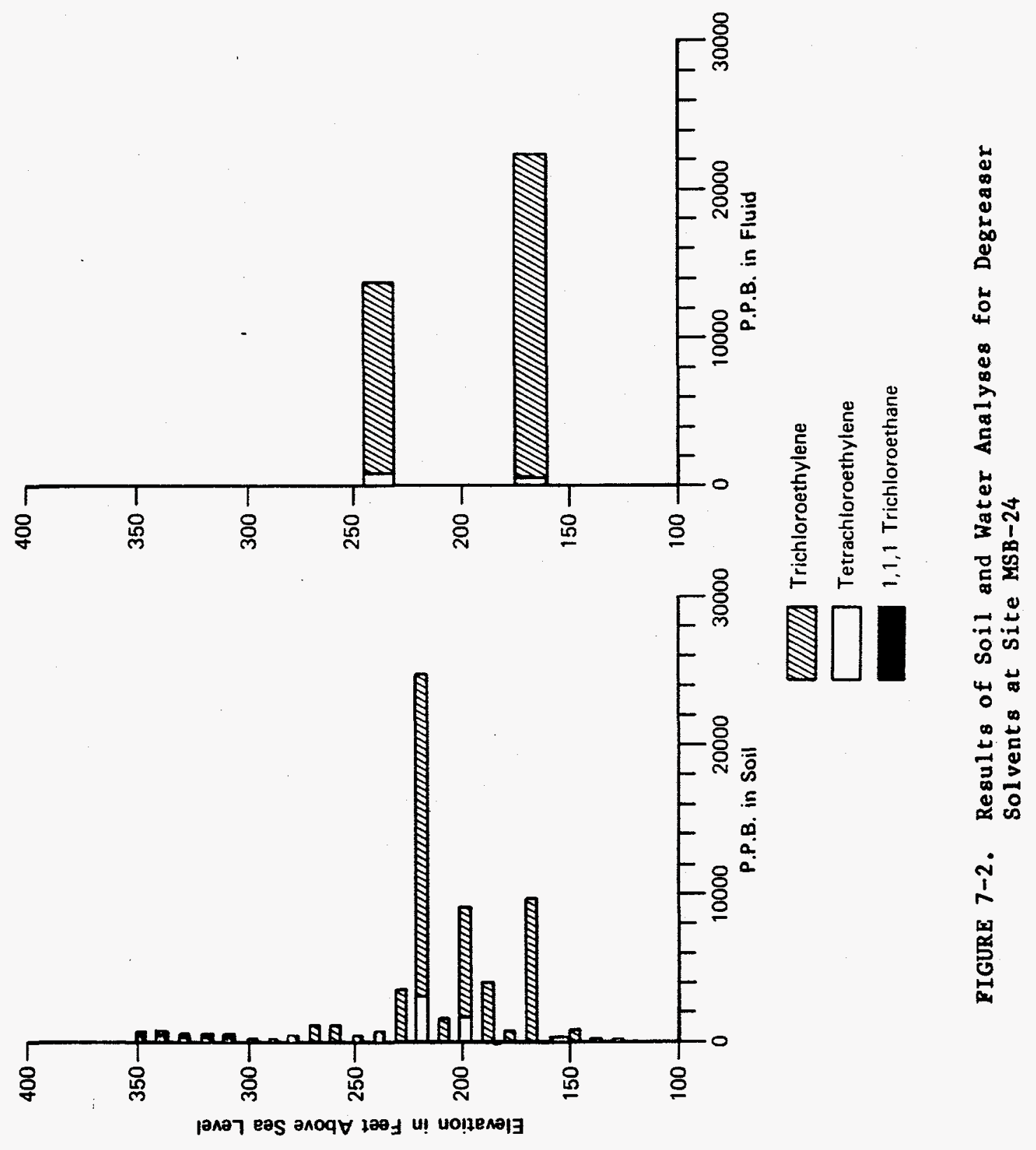




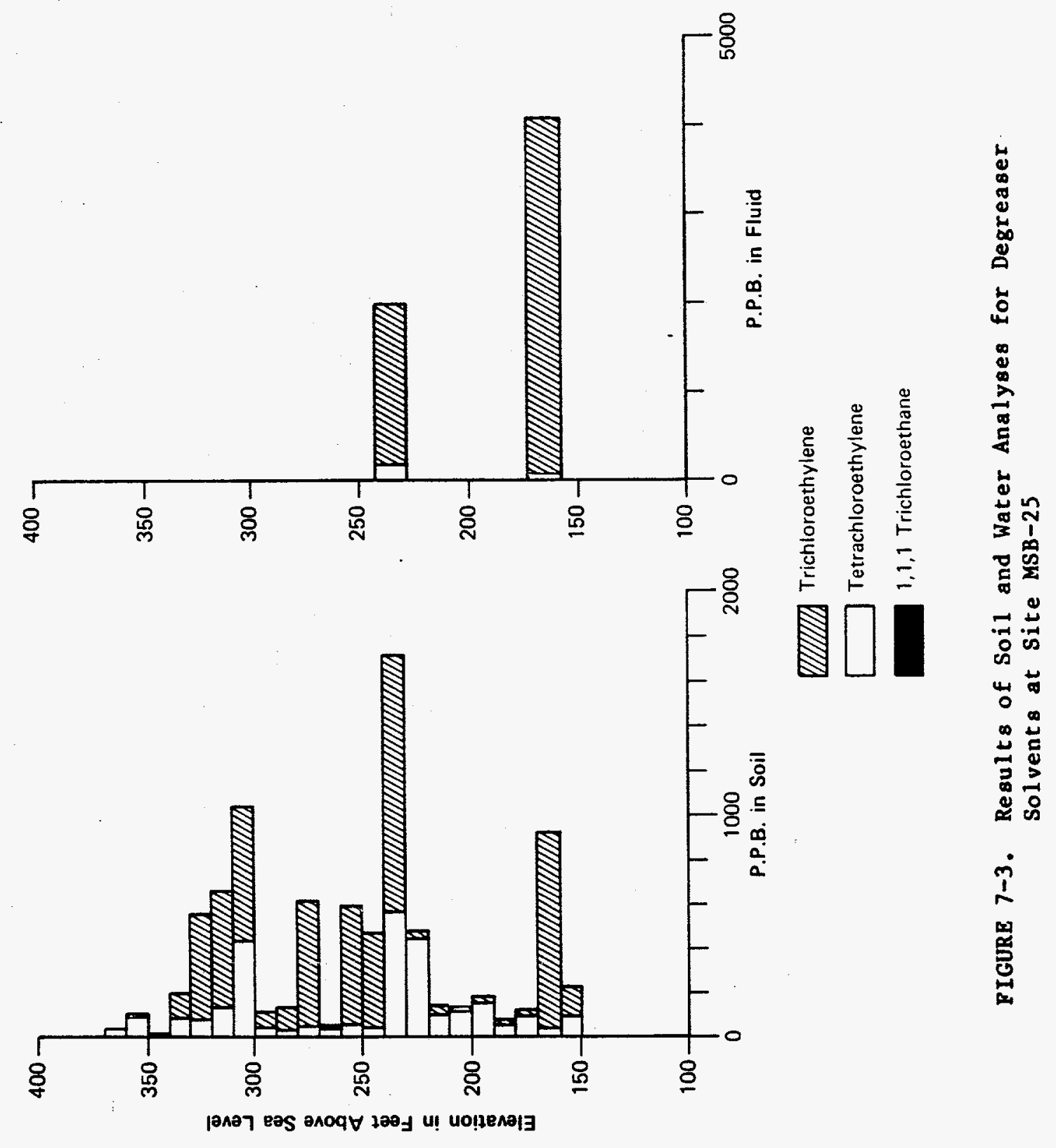




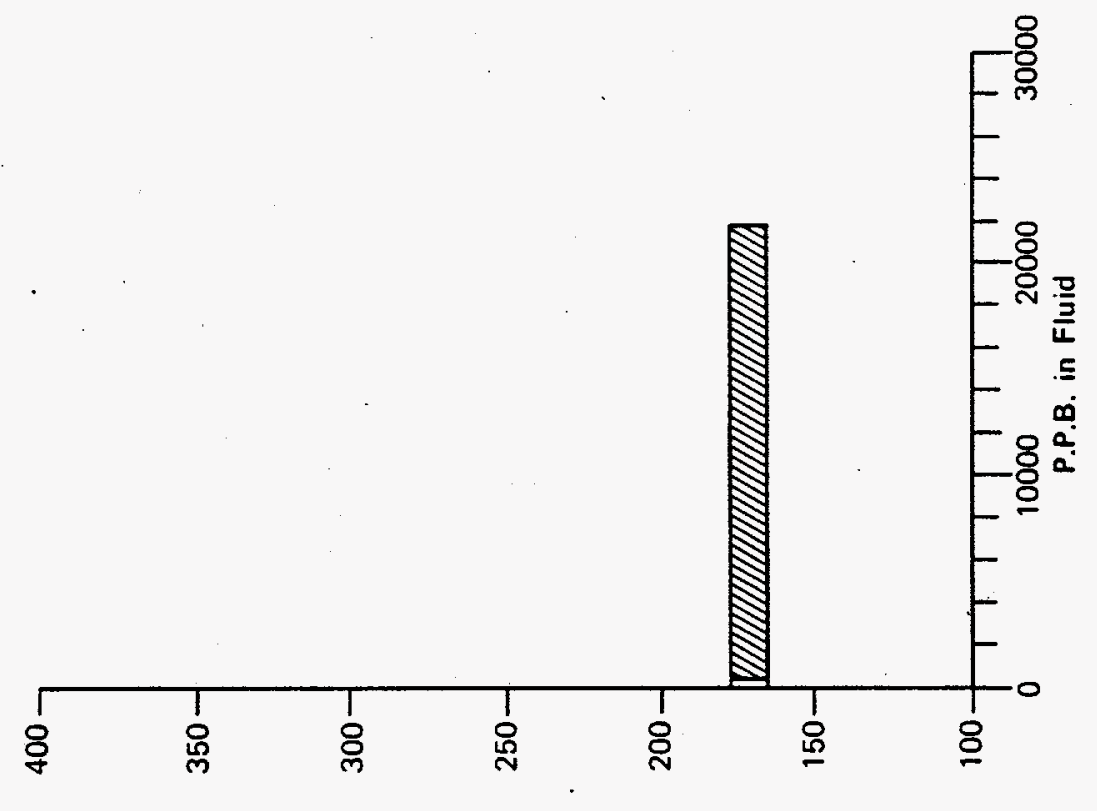

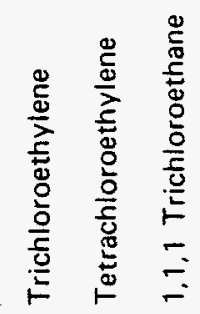

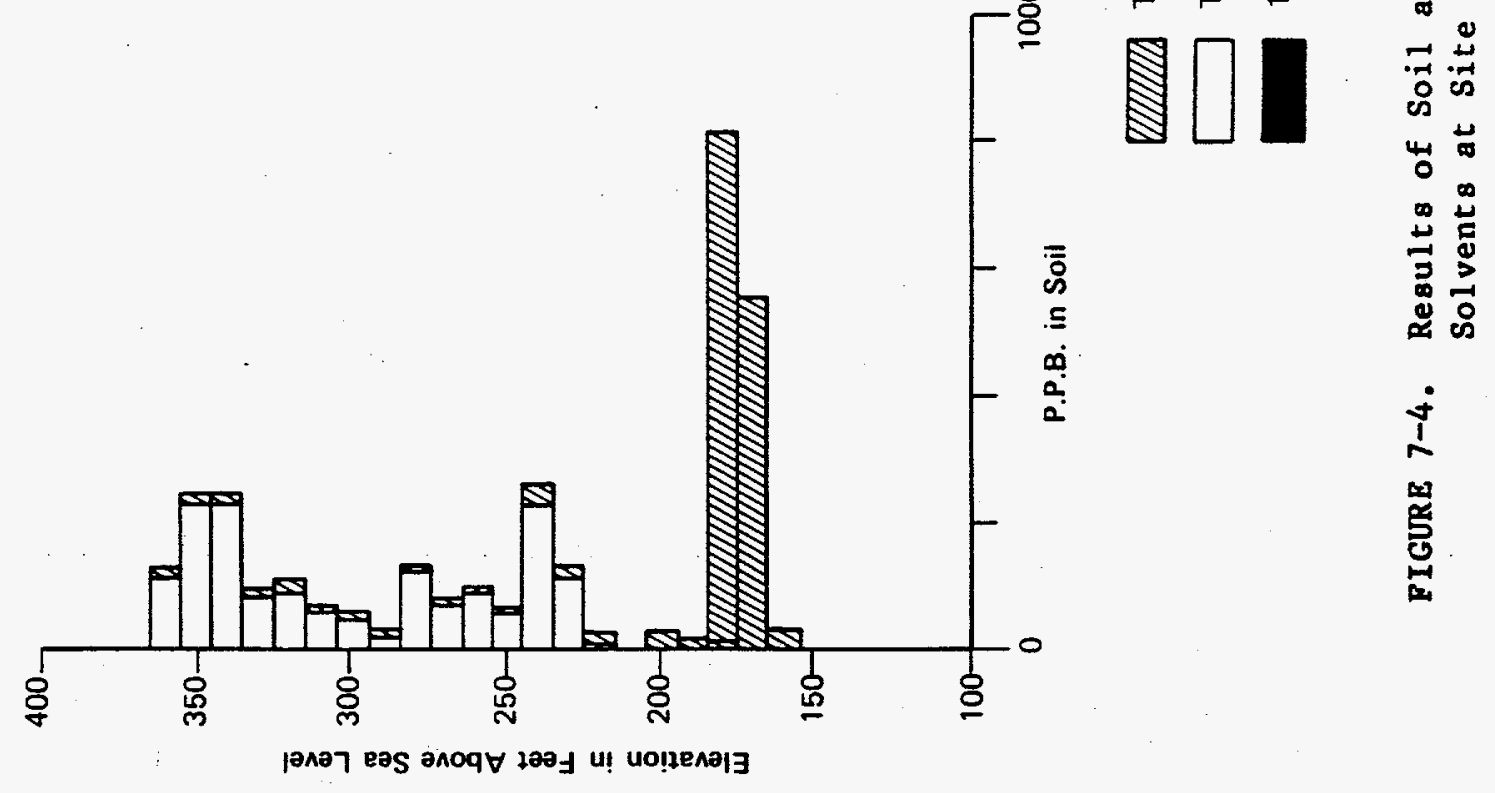




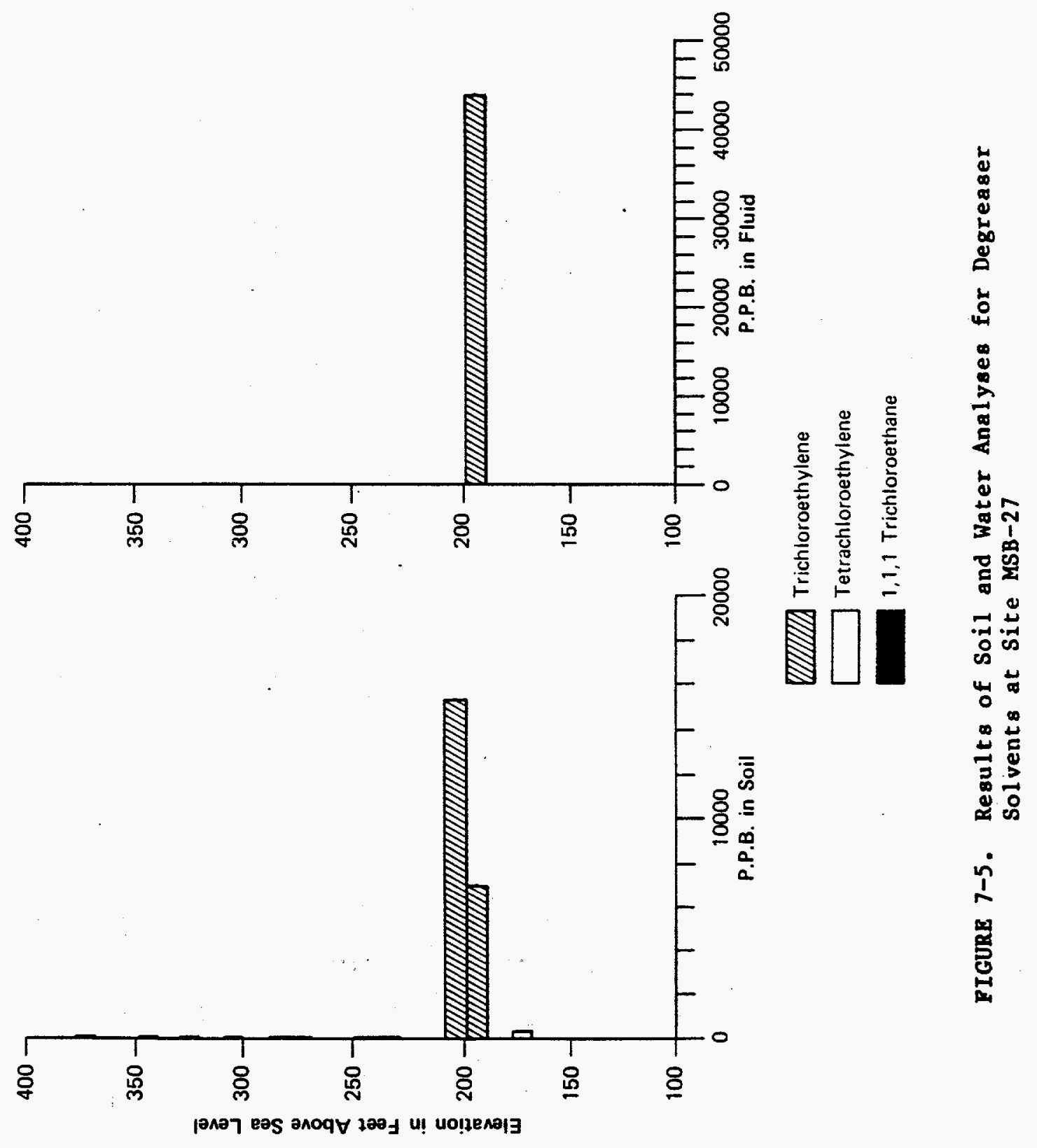




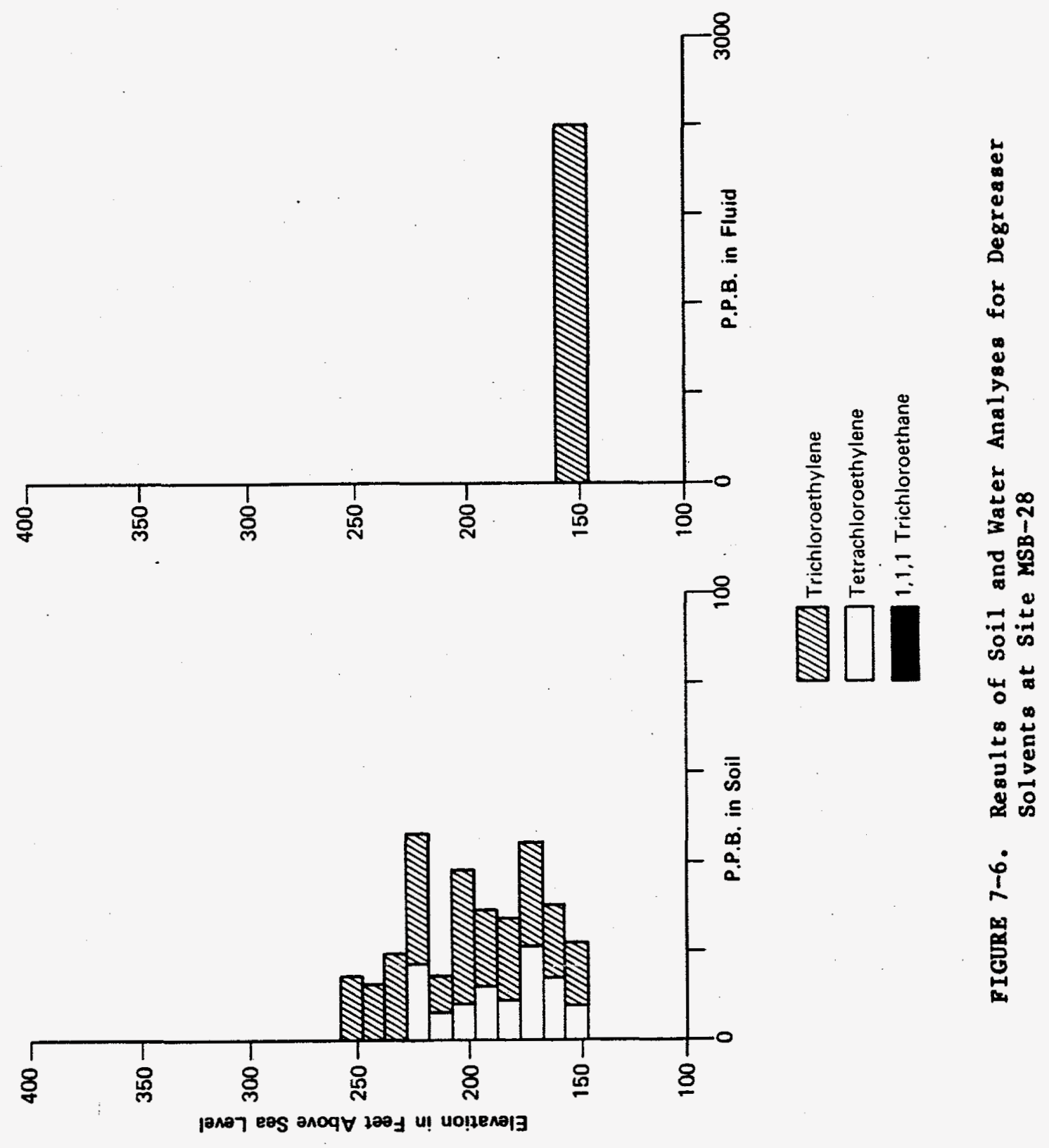




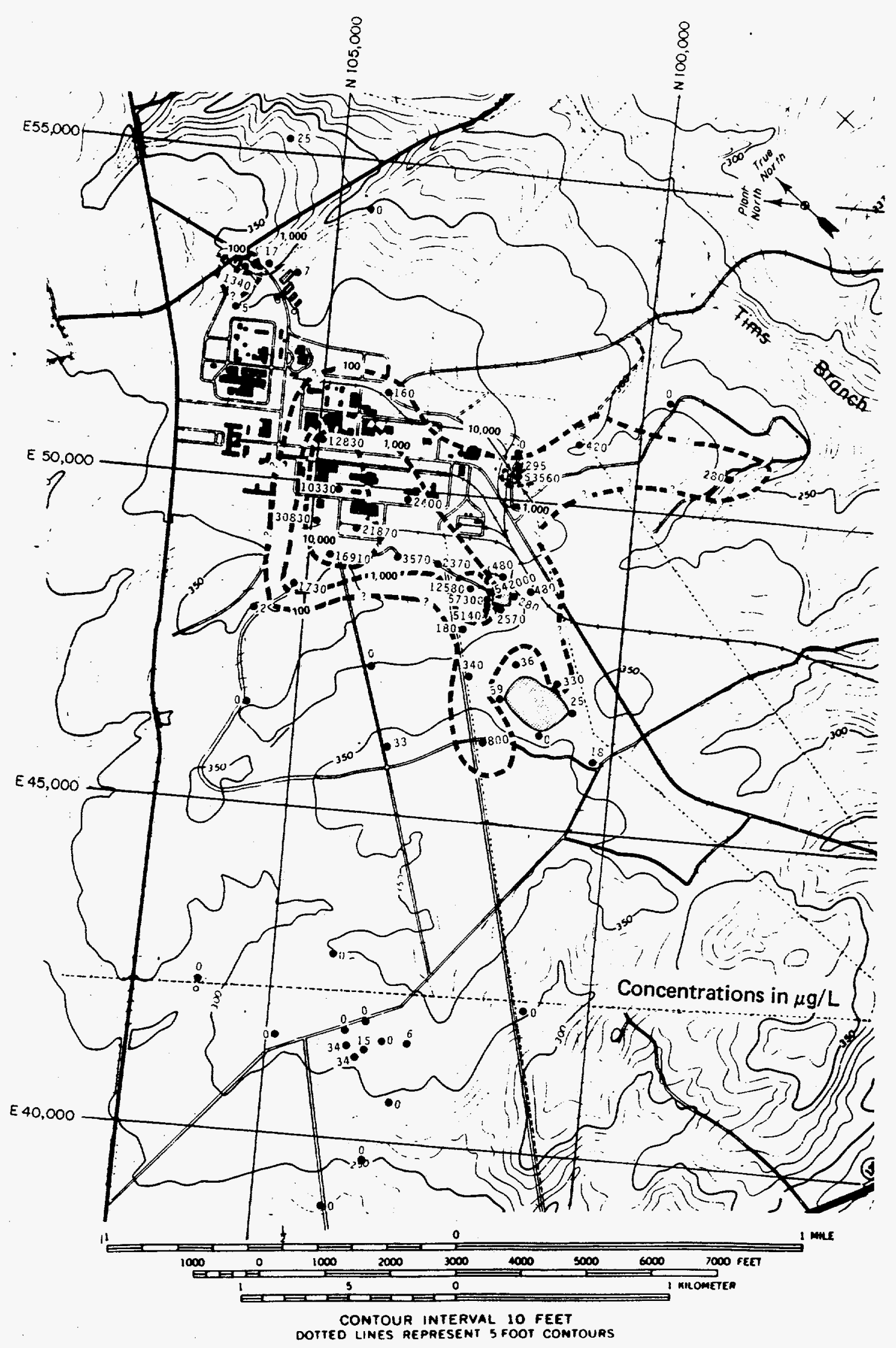

FIGURs 7-7. Contour Map of Vertical Averaged Concentration of Total Degreaser Solvents from Fluid Samples (April-July 1984) 


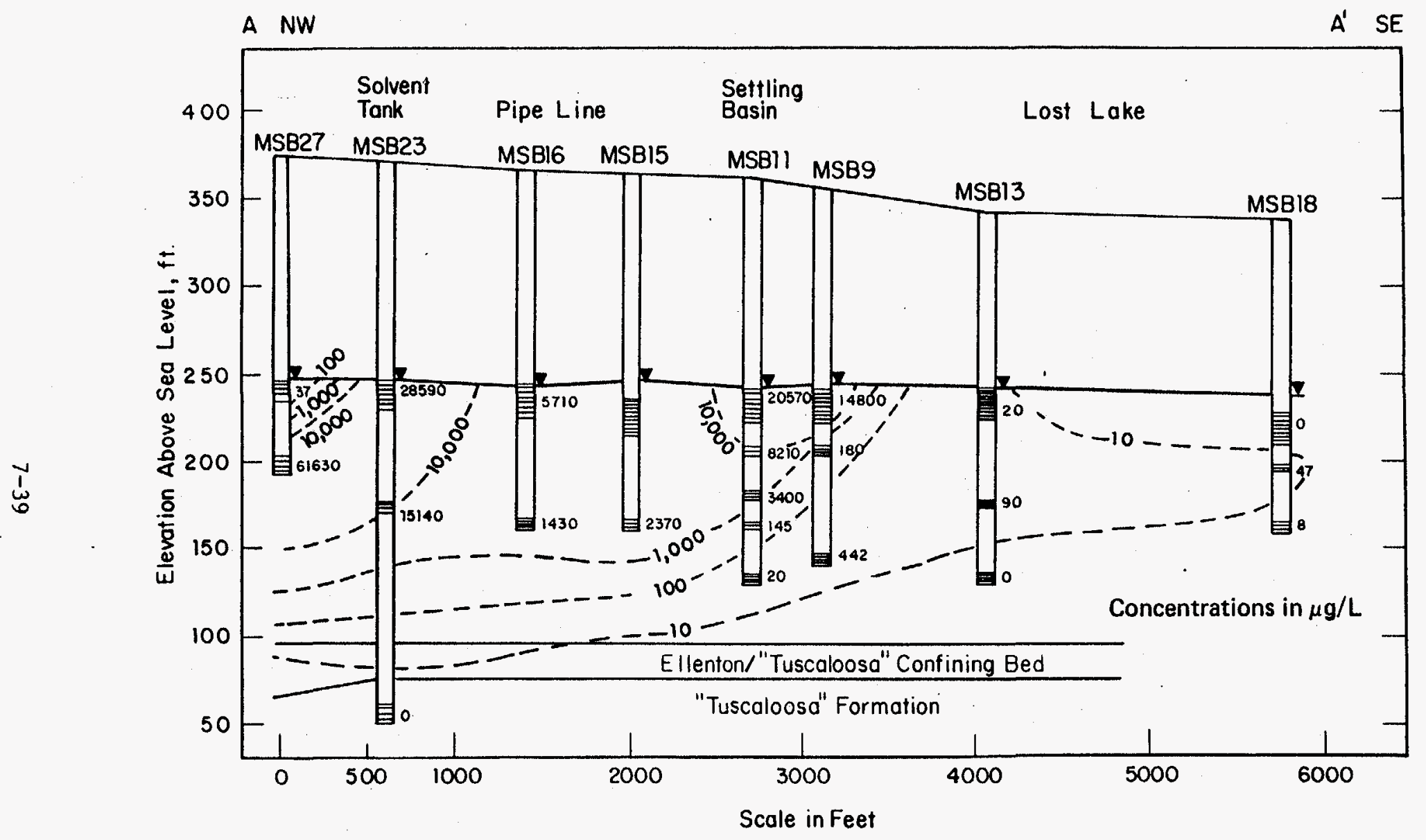

FIGURE 7-8. Vertical Section Passing Through Solvent Storage Tank, Settling Basin, and Lost Lake Showing Concentrations of Total Degreaser Solvents in Groundwater, July 1984 (Editorial Note: Dipping the $10 \mathrm{~g} / \mathrm{L}$ contour into the Ellenton/"Tuscaloosa" confining bed is not supported by more recent data.) 


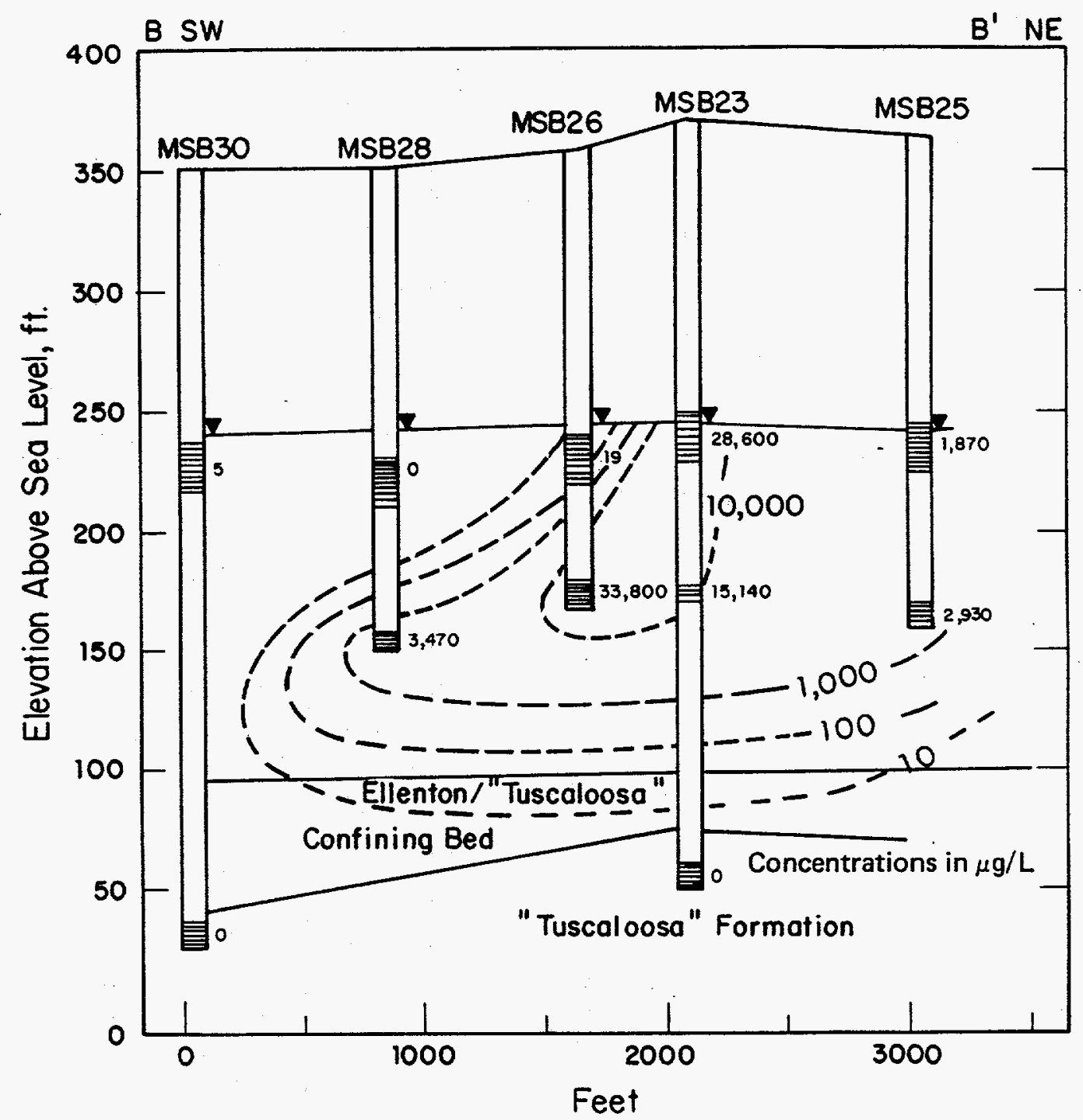

FIGURE 7-9. Vertical Section Along Groundwater Gradient from the Solvent Storage Tank Showing Concentrations of Total Degreaser Solvents in Groundwater, July 1984

(Editorial Note: Dipping the $10 \mathrm{~g} / \mathrm{L}$ contour into the Ellenton/"Tuscaloosa" confining bed is not supported by more recent data.) 


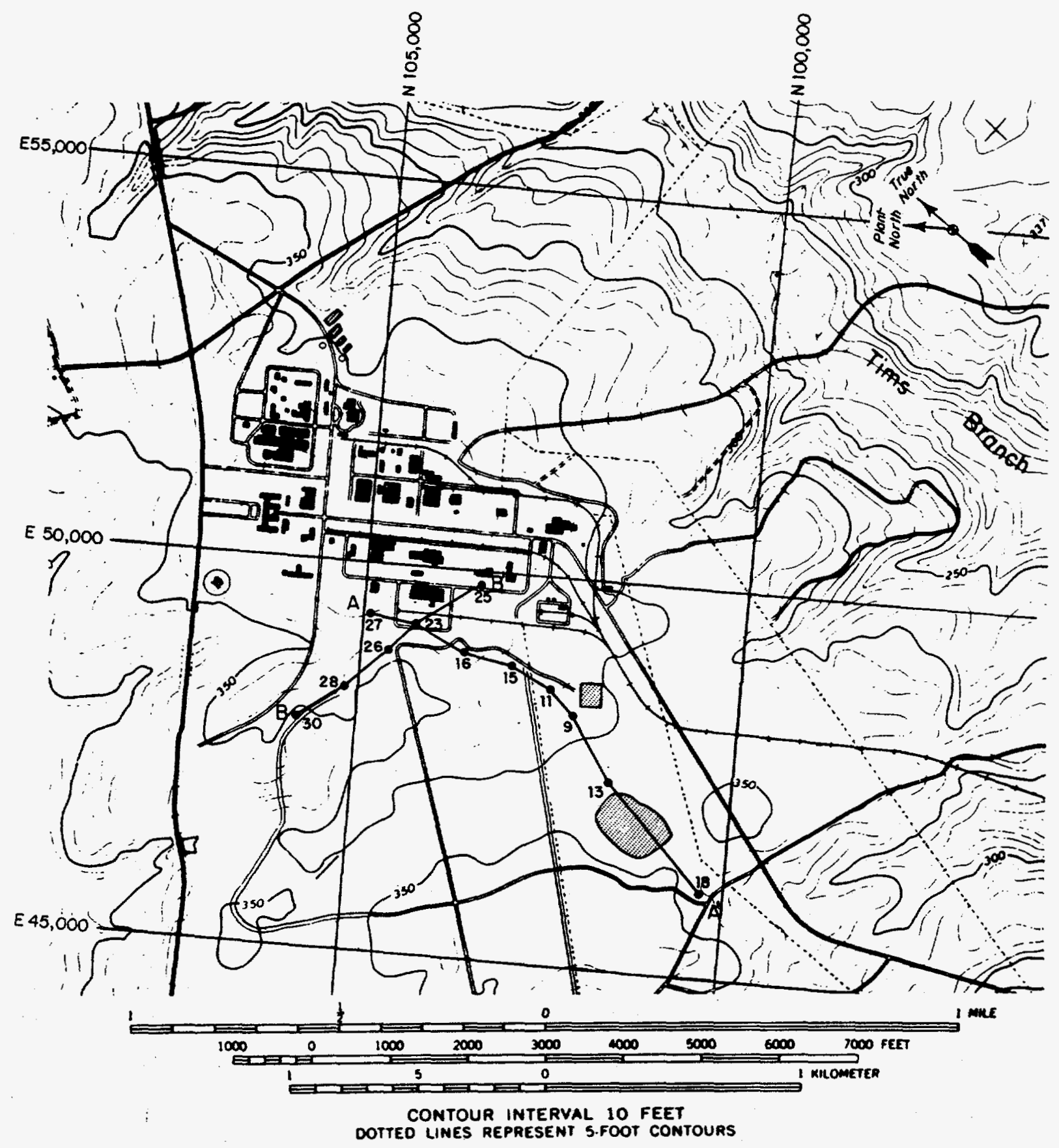

FIGURE 7-10. Location of Vertical Sections Shown on Figures $7-8$ and $7-9$ 


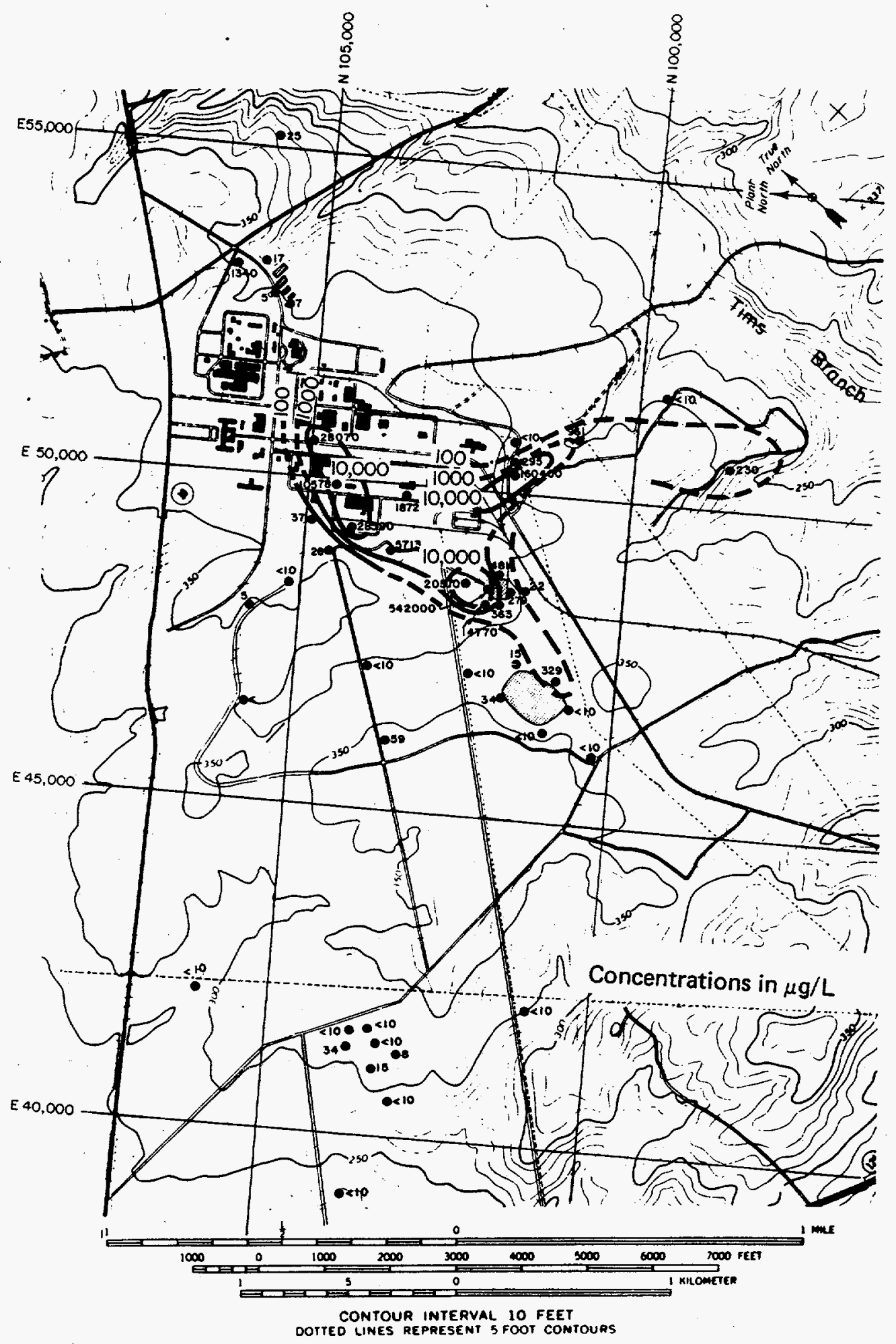

FIGURE 7-11. Contour Map of Concentrations (Spring 1984) of Total Degreaser Solvents at the Water Table 


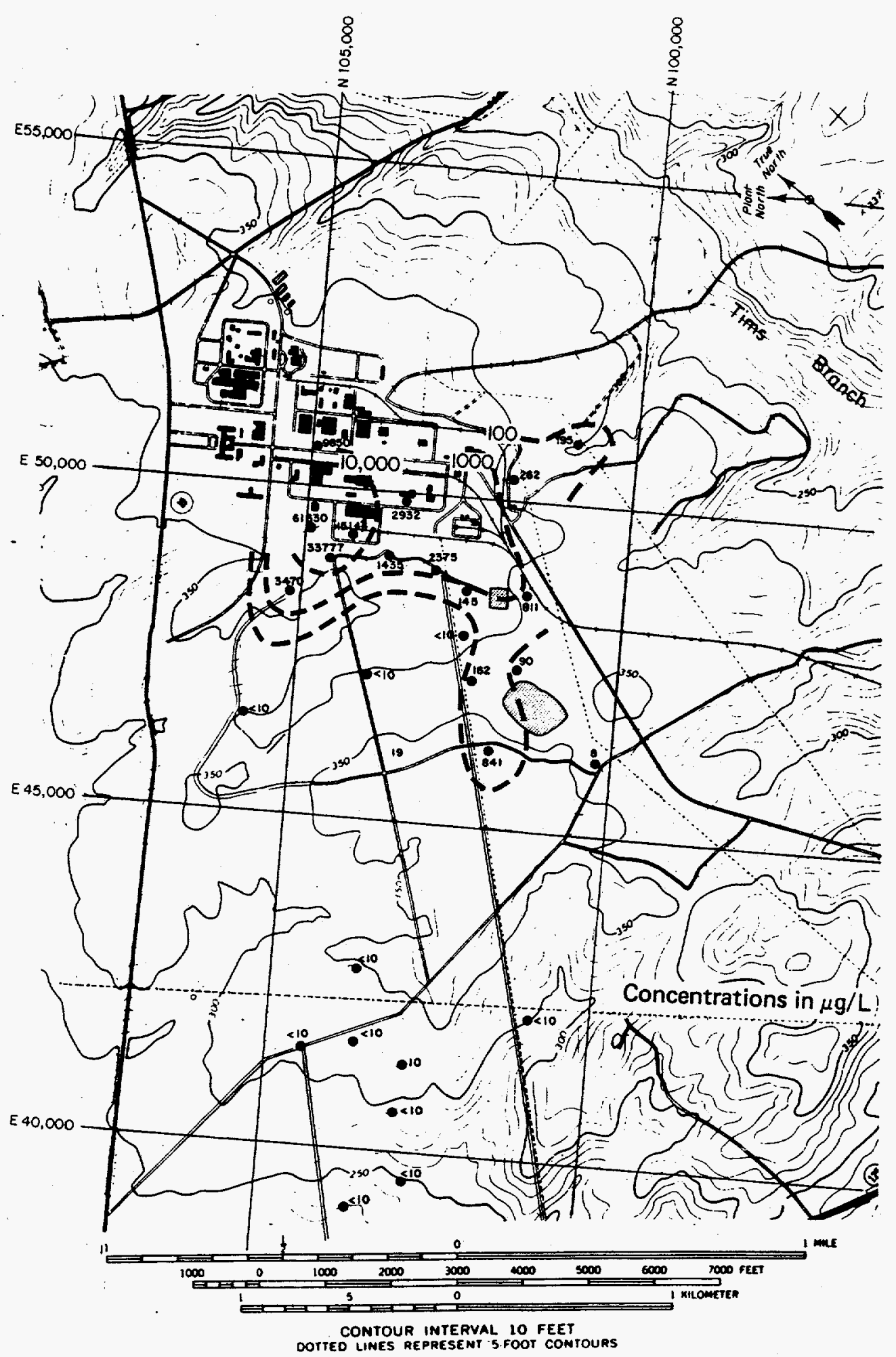

FIGURE 7-12. Contour Hap of Concentrations (Spring 1984) of Total Degreaser Solvents Between Elevation 146 and $187 \mathrm{ft}$, i.e., 50 ft Below the "Green Clay", Using the Same Wells as Used for the Potentiometric Map of this Interval (Figure 5-4) 
$77-l$

( $\zeta-\varsigma$ axn8ti ) IRAsojuI

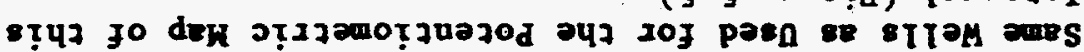

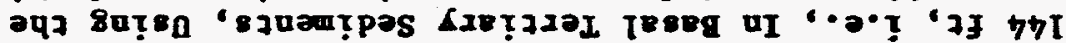

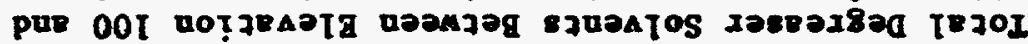

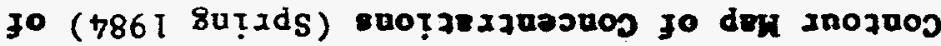

$\cdot \varepsilon T-L$ ganoIa

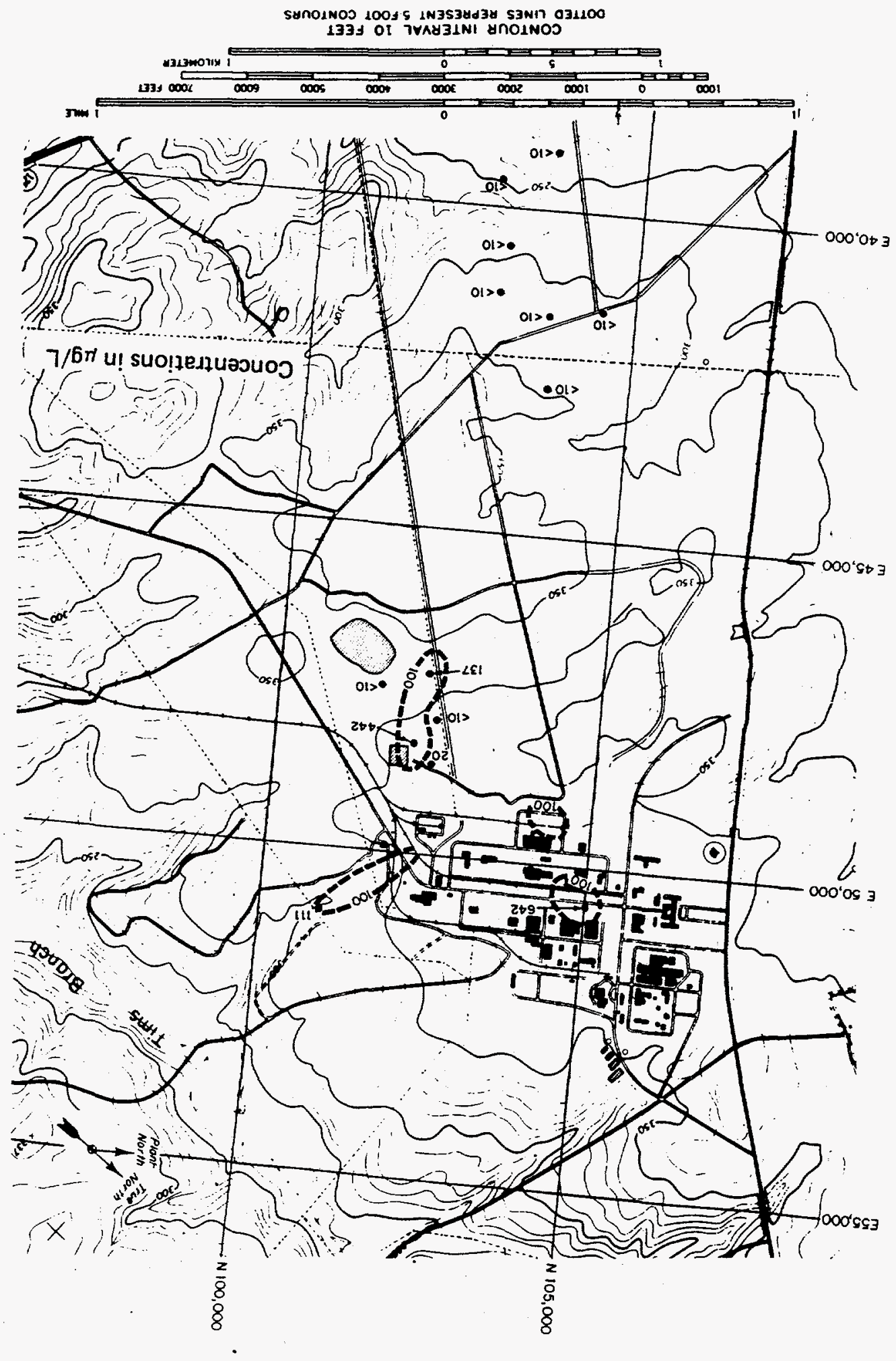




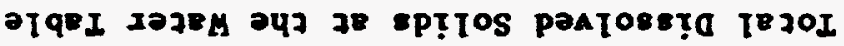

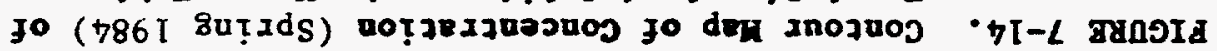

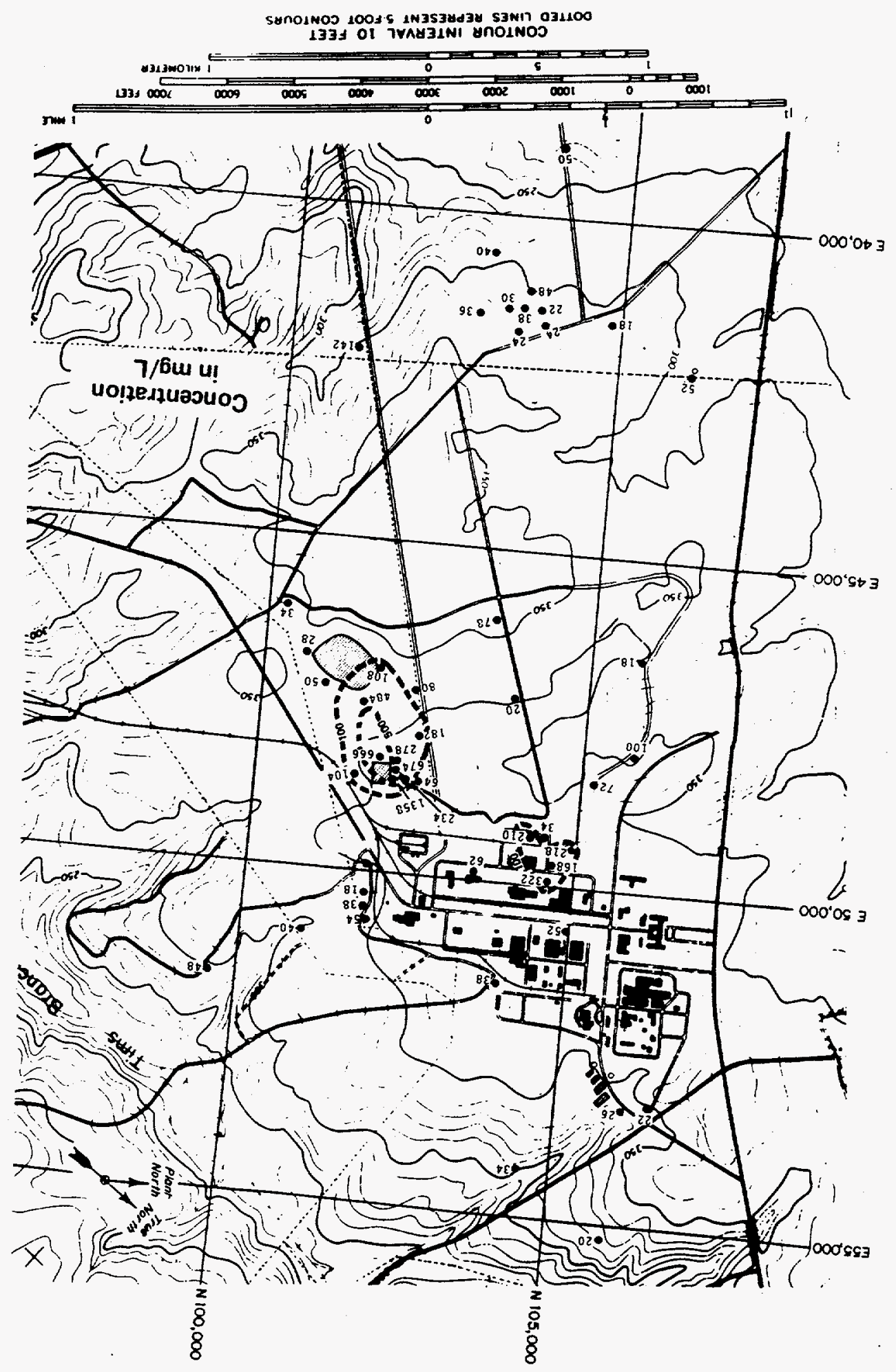




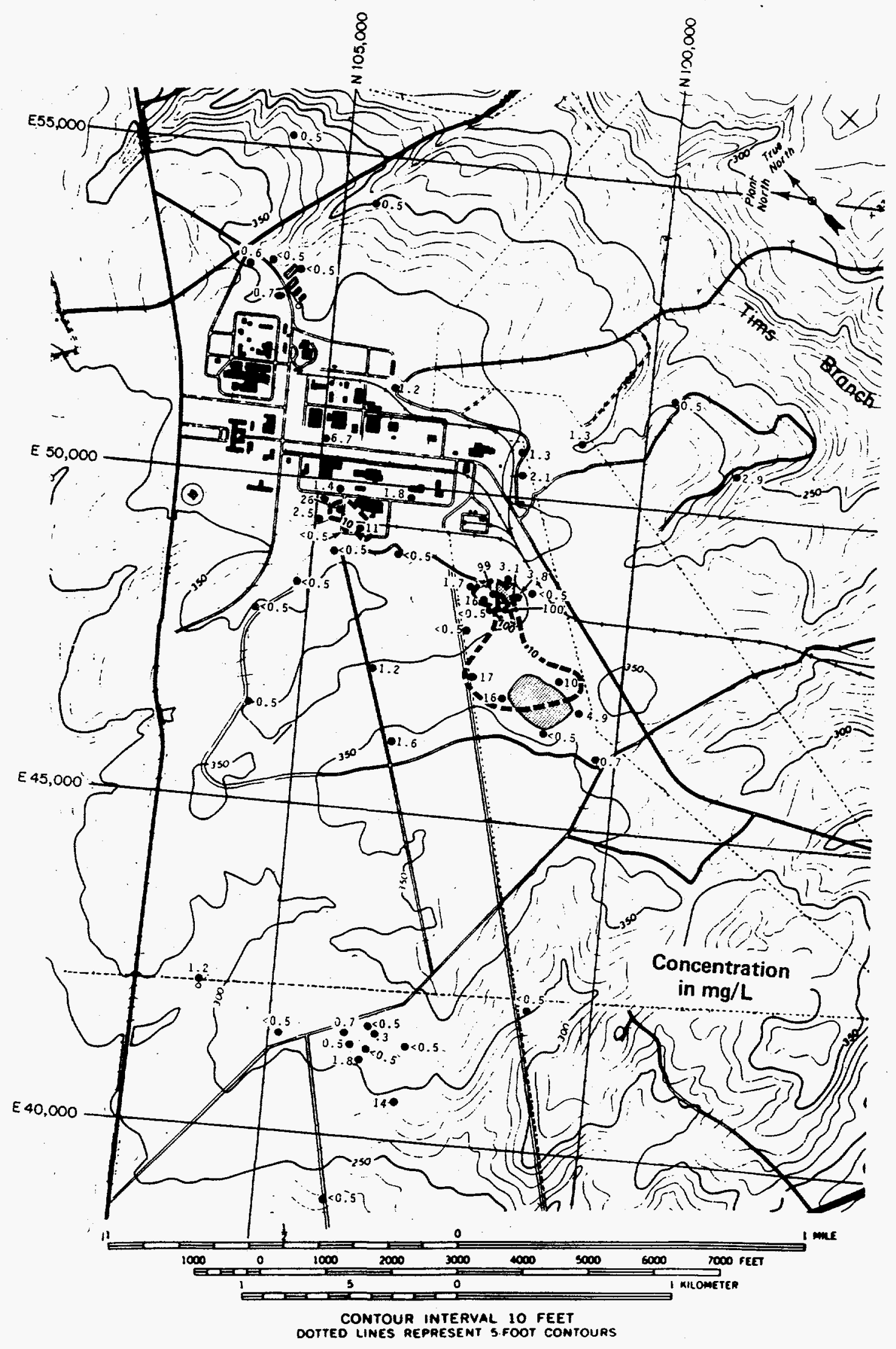

FIGURE 7-15. Contour Map of Concentration (Spring 1984) of Nitrate at the Water Table (Reported as Nitrogen) 


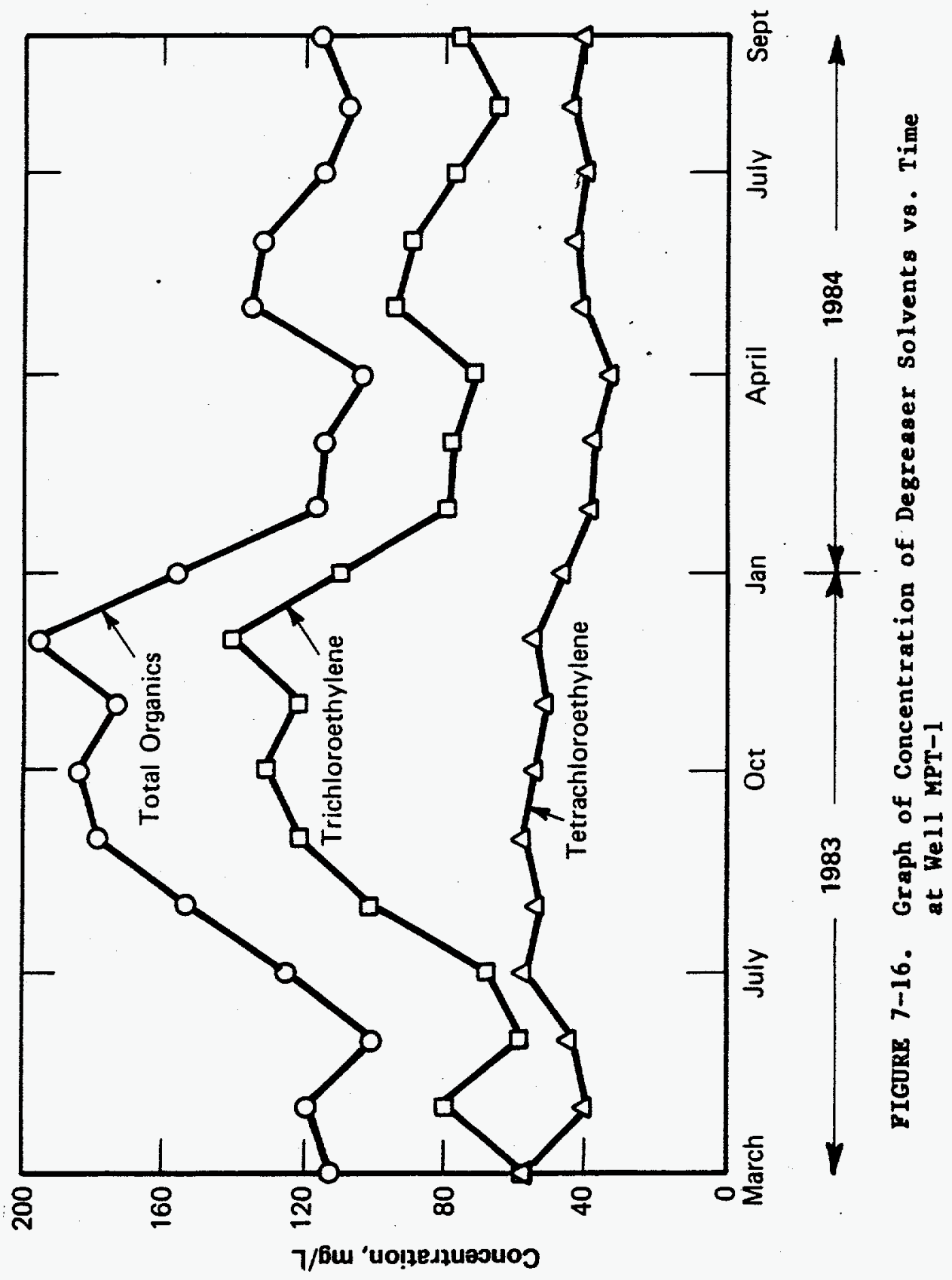


$87-1$

IOjenpanolg coIJ sJuantos

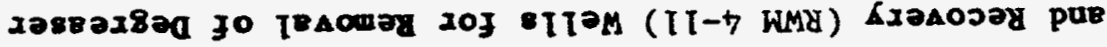

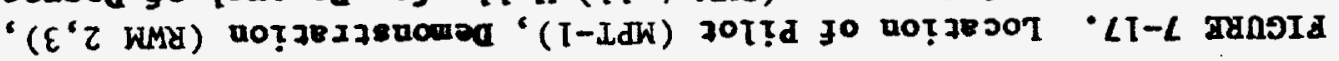

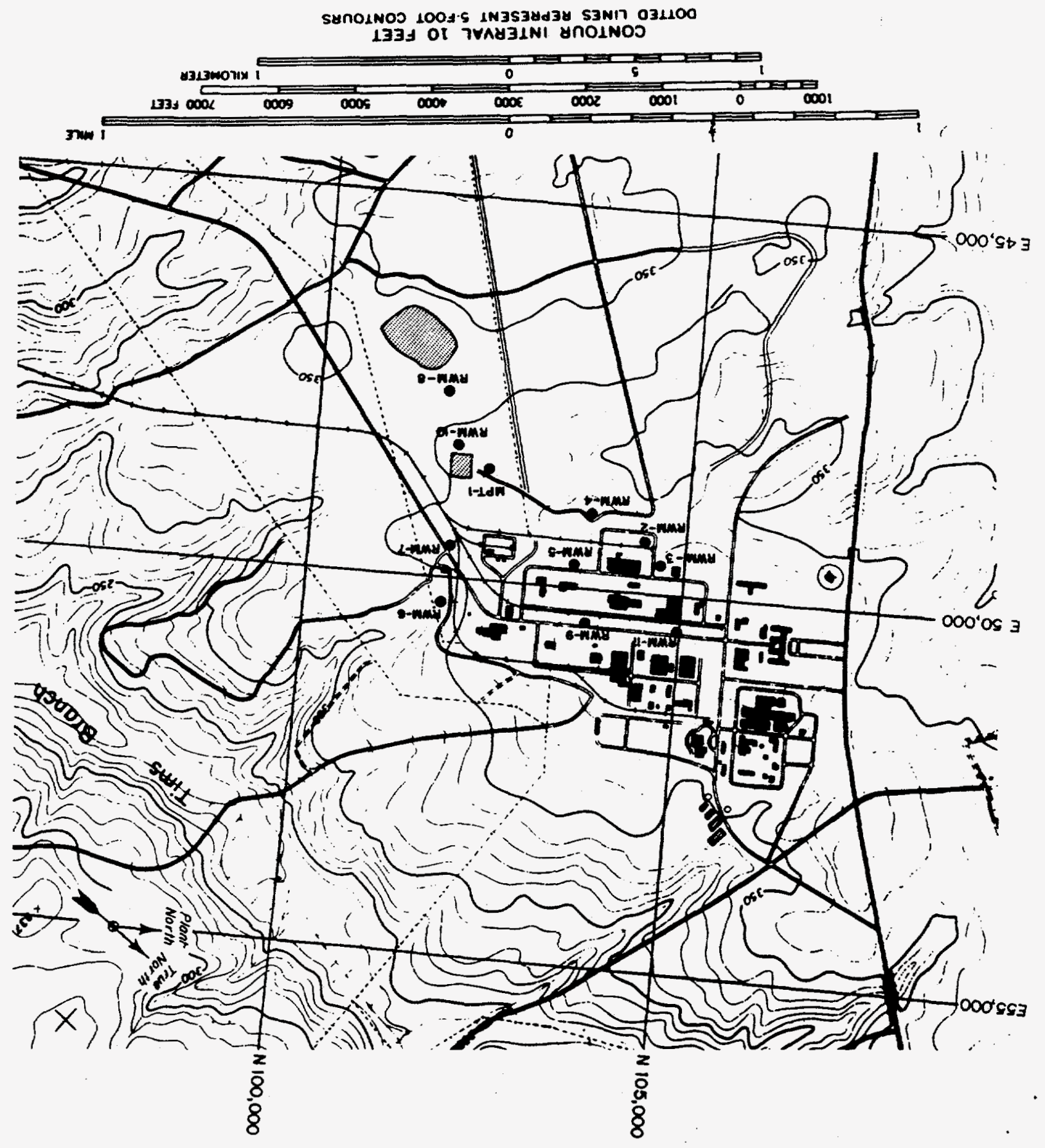




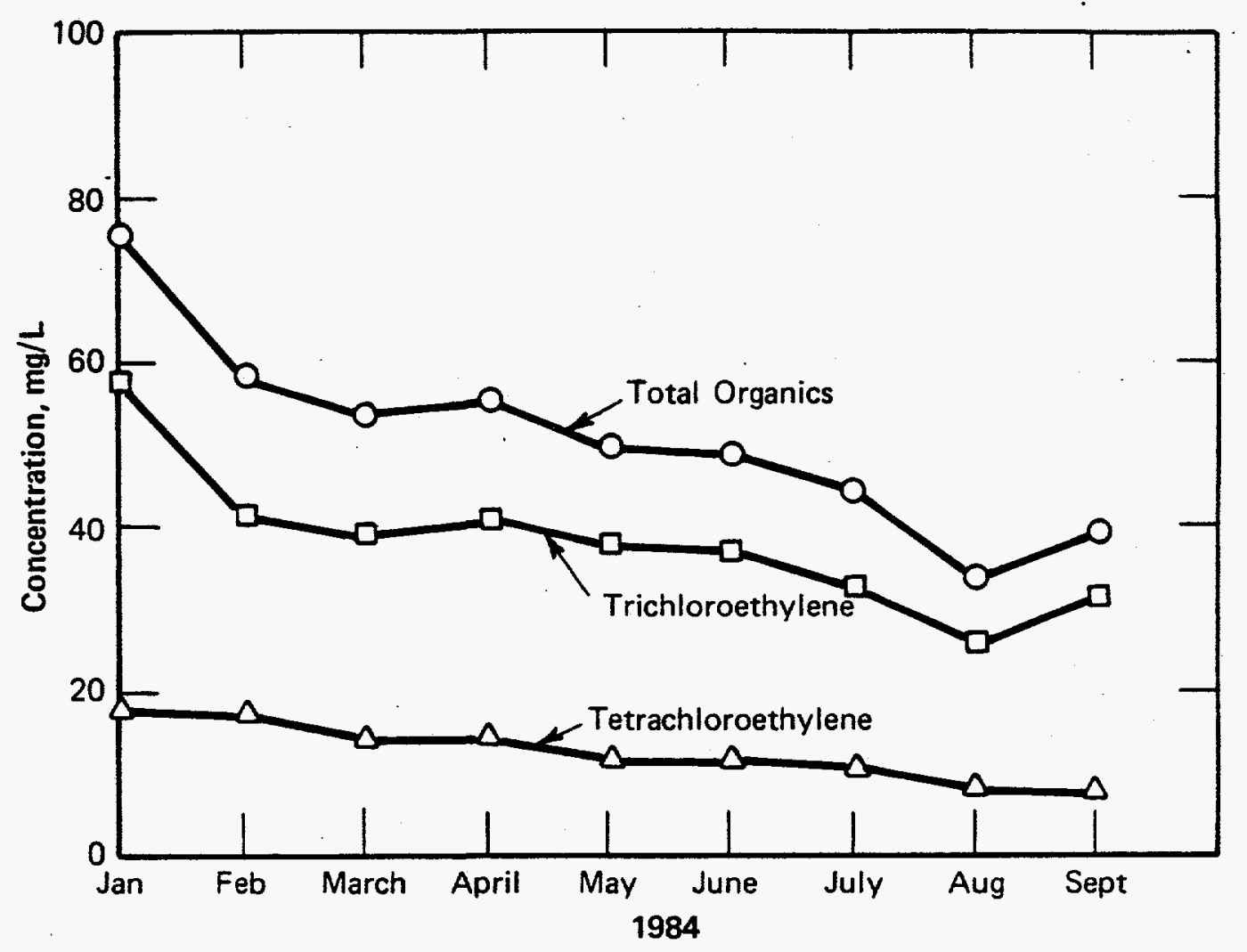

FIGURE 7-18. Graph of Concentration of Degreaser Solvents v8. Time at Well RWM-2 


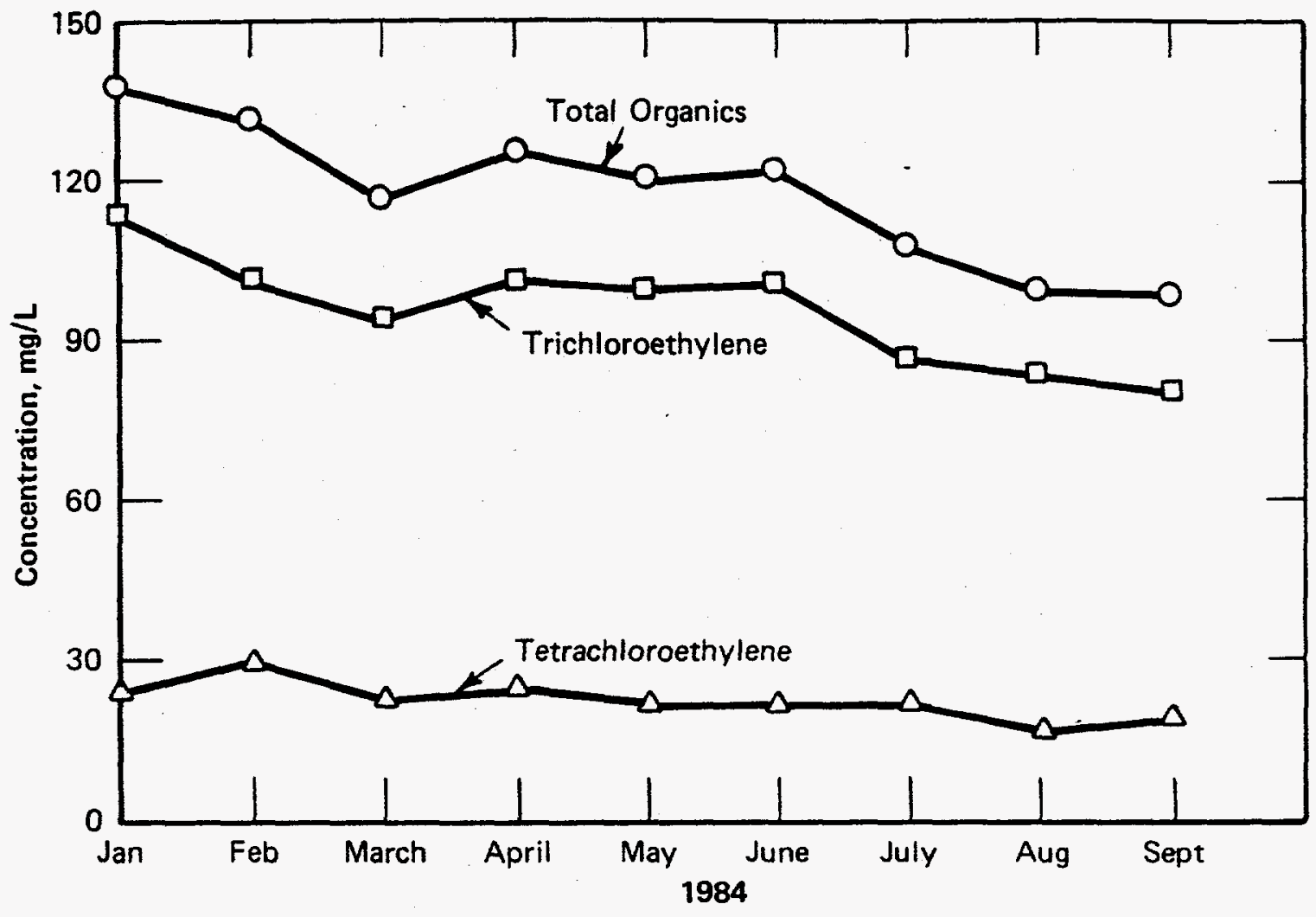

FIGURE 7-19. Graph of Concentration of Degraser Solvents V8. Time at We11 RWM-3 


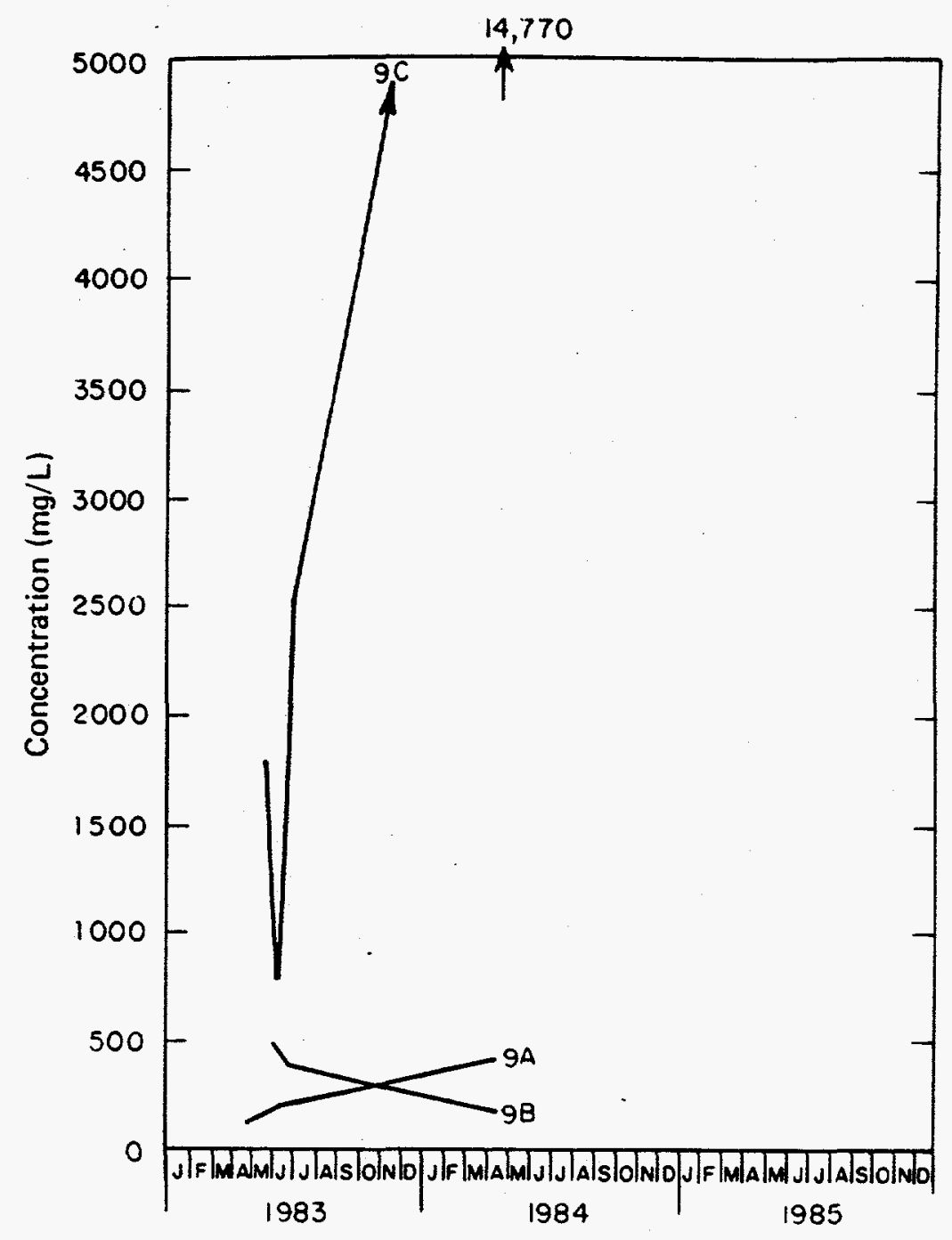

FIGURE 7-20. Graph of Time/Concentration for Trichloroethylene Plus Tetrachloroethylene in Water from Wells in Cluster MSB-9

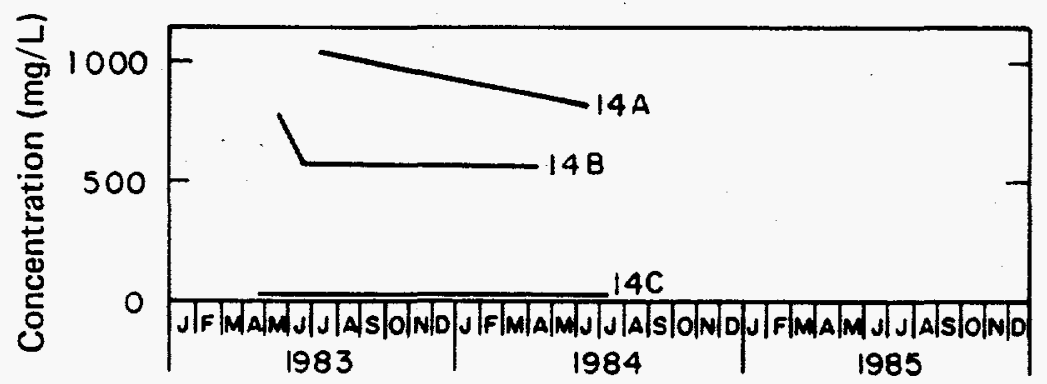

FIGURE 7-21. Graph of Time/Concentration for Trichloroethylene Plus Tetrachloroethylene in Water from Wells in Cluster MSB-14

$$
7-51
$$




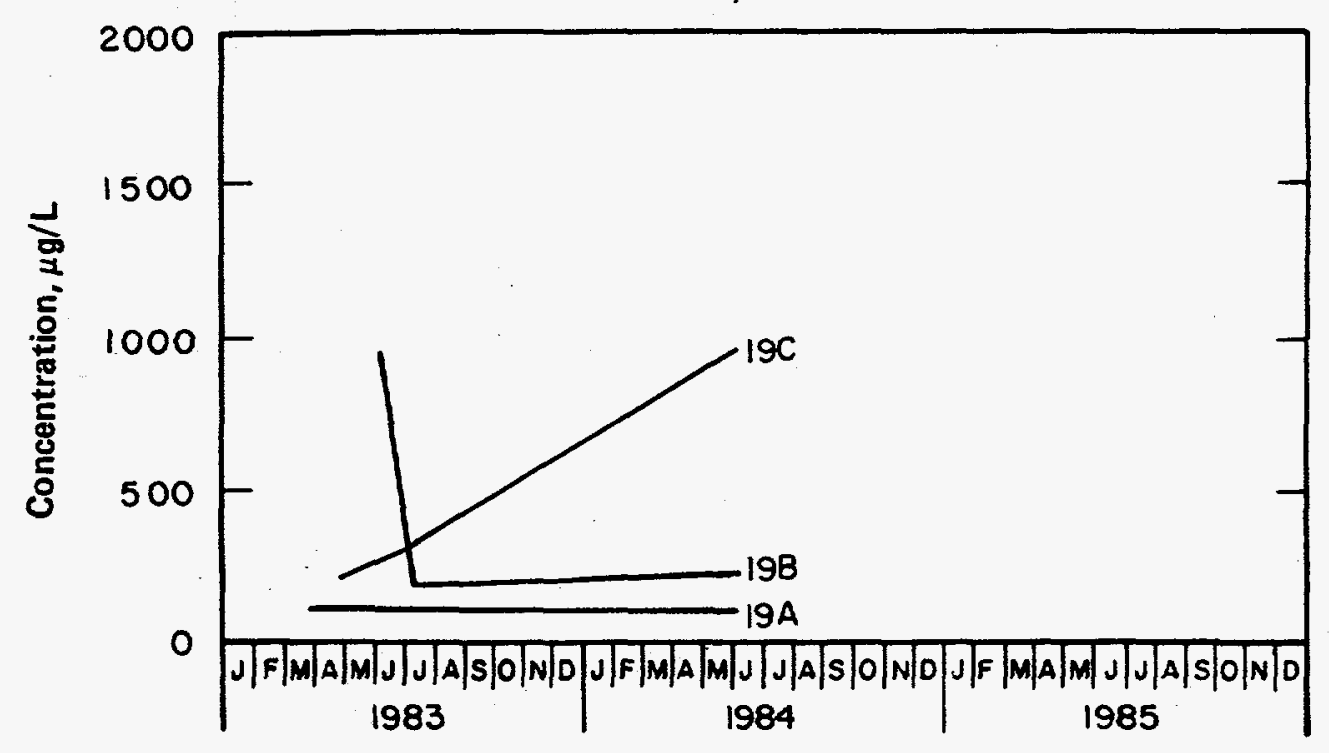

PIGURE 7-22. Graph of Time/Concentration for Trichloroethylene Plus Tetrachloroethylene in Water from Wells in Cluster MSB-19

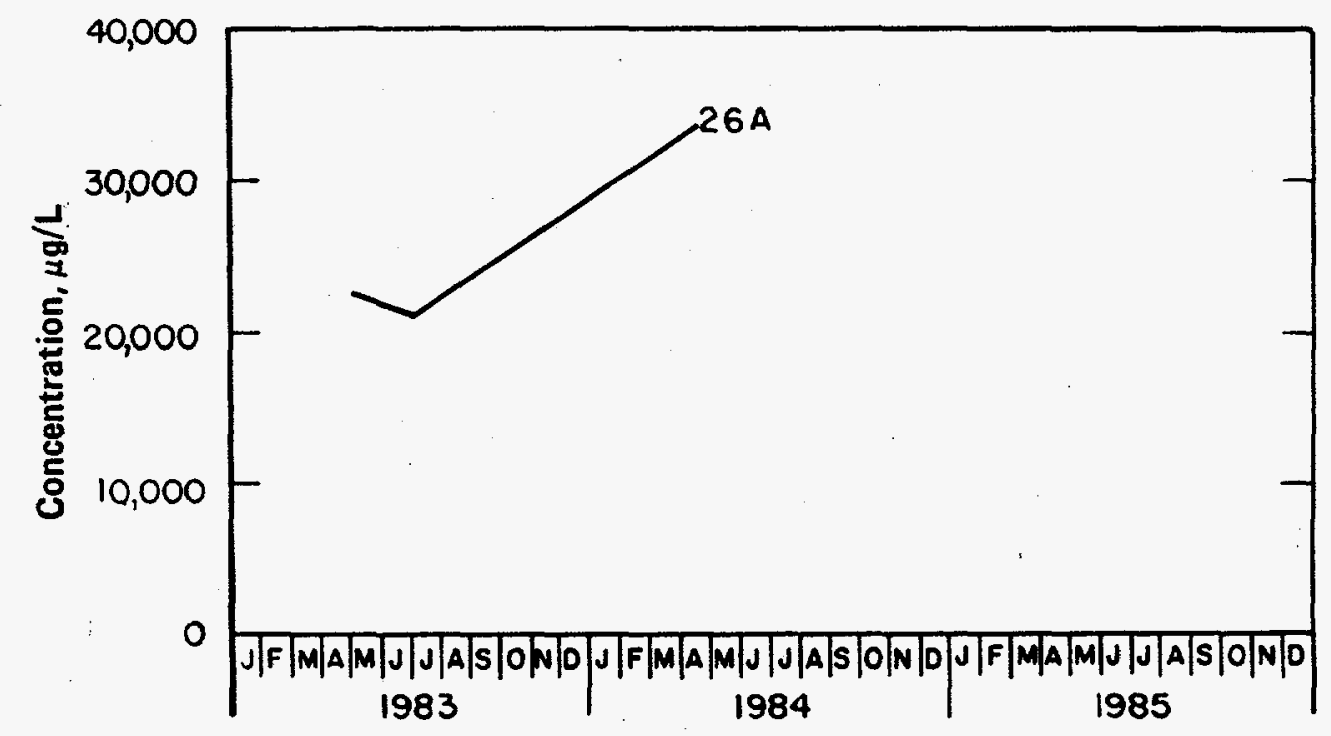

FIGURB 7-23. Graph of Time/Concentration for Trichloroethylene Plus Tetrachloroethylene in Water from Well MSB-26A 


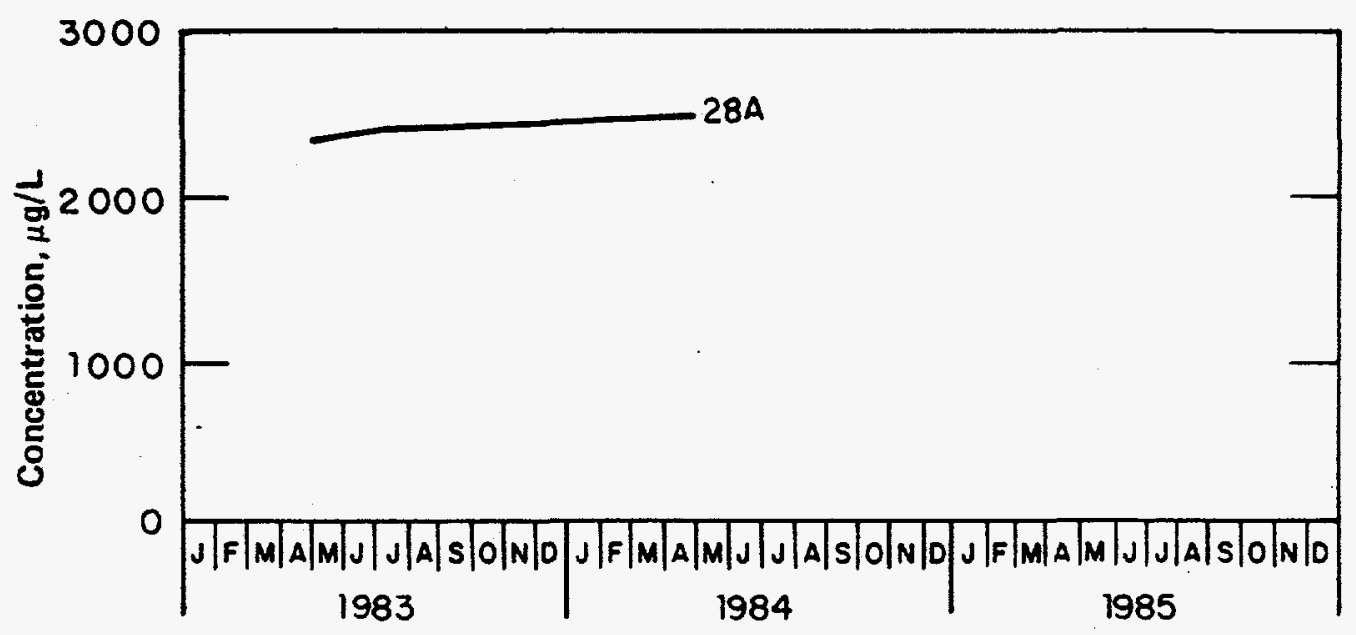

FIGURE 7-24. Graph of Time/Concentration for Trichloroethylene Plus Tetrachloroethylene in Water from Well MSB-28A 
$7-54$ 
At SRP, identifying well numbers are assigned according to the project or purpose for which the wells were installed. Although the location coordinates on the SRP wells are known, the identifying number is not based on the location of the well. The identifying well number generally consists of three parts: (1) a series of three letters that identify the project or purpose of the well, (2) a serial number of up to three digits identifying its sequence position in the project, (3) up to two letters that identify an individual well's relative depth if it is part of a cluster of wells at the same location. The well "A" is generally the deepest well in a cluster, " $B$ " the next deepest, etc; so that "F" or "G" may be the shallowest. This is done because usually the first well in a cluster (A) is cored to a predetermined depth and the depth of other wells in the cluster are selected from the geological and geophysical logs of that hole. Occasionally there is a need to drill a well deeper than the original cored hole and such a well may receive a two letter suffix (such as TA). For example:

- MSB 9A is the deepest well in the ninth location drilled for investigating the contaminant plume at the M-Area settling basin.

- $A C-2 B$ is the shallower of two wells at the second location drilled in the A-Area cluster series.

- MSB-34 TA is the deepest well in the "Tuscaloosa" Formation at the 34 th location in the MSB series.

The project series that are included in $A / M$ Area are given in Table A-1. 
TABLE A-1

Prefix Letter and Project Series in A/M Area

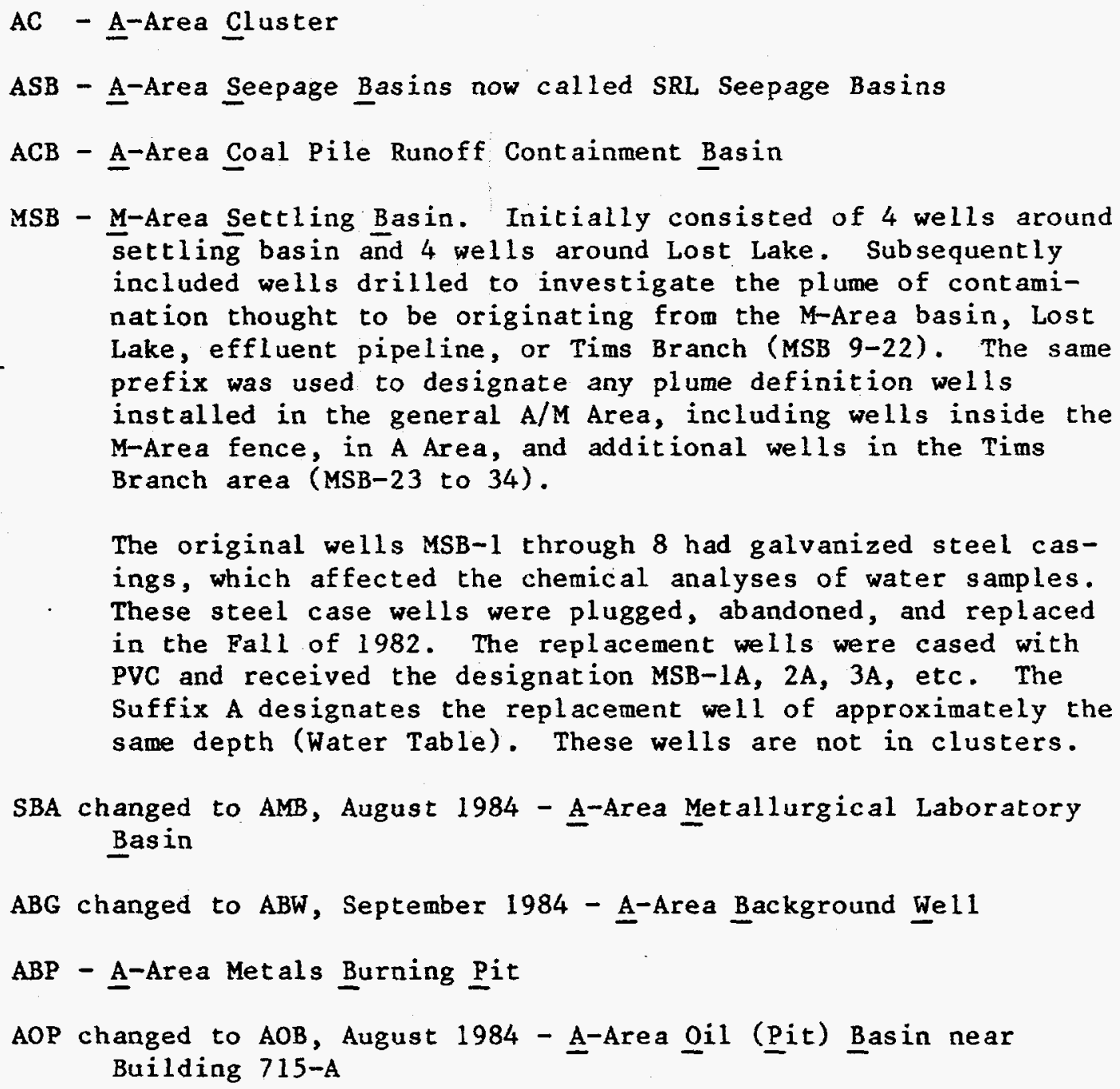

LA changed to 905 in 1962 - original water production wells drilled by Layne Atlantic, Co. during construction of SRP. Shown as PW (Production Well) in Well Data File.

905 reads PW in Well Data File - Water Production Well. For these wells the suffix A stands for the A Area not deepest well in cluster; $G$ stands for gate house or general area. These wells are not in clusters.

SR changed to SRW, September 1984 - Silverton Road Waste Site 
TABLE A-1, Contd

S - Wells previously existing when SRP took over property in 1951 .

MPT - M-Area production Test Well

RWM - Recovery Well M Area

ARP - A-Area Burning $\underline{\text { Rubble Pits }}$

P - Bedrock Piezometer

The following project series consist of foundation exploration borings that were subsequently slosed without installing wells.

ESM - DuPont Engineering Department Soil Map Borings

ESN - Also DuPont Engineering Department Soil Map Borings

IM - Foundation Investigation Borings M-Area (U.S. Army, Corps of Engineers)

IMV - Foundation Investigation Borings (J.S. Army, Corps of Engineers)

IXM - Foundation Investigation Borings (U.S. Army, Corps of Engineers) 


$$
\text { A-4 }
$$


APPENDIX B. CONCENTRATIONS OF DEGREASER SOLVENTS IN WATER FROM MONITORING WELLS

The table in this appendix gives the concentration of 1,1,1-trichloroethane, trichloroethylene, tetrachloroethylene, and the total of these in water samples from monitoring wells. The locations of the monitoring wells are shown on Figure 4-1.

Analysis is by gas chromatograph except that analyses performed on samples from 4-84 to 7-84 were by GC/MS. Results are given by well and then by sampling date. Results are given in micrograms per liter (parts per billion). LT stands for "less than". N stands for "not reportable".

Except for the samples from well MSB-23A on $6 / 27 / 84$ and $7 / 10 / 84$, all samples are pumped from the well by a dedicated pump. The sampling protocol is given in Appendix E-1.

Samples from well MSB-23A, an upper Tuscaloosa monitoring well were taken by the method given in the protocol (Appendix E-1) except for the samples on $6 / 27 / 84$ and $7 / 10 / 84$. Samples on these dates were collected by the bailer method. It was suspected that the cement sheath in the annulus between the casing and the ground was leaking, causing contaminated water from the Tertiary sediments above to migrate downward to the "Tuscaloosa" Formation. Bailer samples were collected to provide more information on this hypothesis. Although investigation into this topic is ongoing, it appears that the hypothesis is correct, and the positive results are dependent on the volume of water removed from the well.

Even with all the quality assurance methods that have been applied, the degreaser solvent concentration in some wells varies many fold with different samples. Thus, conclusions about changing concentrations with time must be carefully examined. Wells that vary more than two-fold in trichloroethylene are MSB-2A, 3A, 9A, 9C, $11 \mathrm{~A}, 11 \mathrm{~B}, 11 \mathrm{D}, 11 \mathrm{~F}, 12 \mathrm{~B}, 12 \mathrm{C}, 13 \mathrm{C}, 16 \mathrm{C}, 17 \mathrm{~A}, 17 \mathrm{~B}, 19 \mathrm{~B}, 20 \mathrm{C}, 22,23$, $23 \mathrm{~B}, 24 \mathrm{~A}$, and 34B. The analyses for all these wells are reported; however, only the results of future sampling will determine if these variations are those that exist in the ground or whether they are due to some variation in the sampling/analysis system. 
. APPENDIX B. CONCENTRATIONS OF DEGREASER SOLVENTS IN WATER FROM WELLS REPORTED IN MICROGRAMS PER LITER (PPB).

\begin{tabular}{|c|c|c|c|c|c|c|c|c|c|}
\hline \multicolumn{2}{|c|}{. WELL } & $\begin{array}{l}\text { SAMPLE } \\
\text { DATE }\end{array}$ & 1,1, & TCE & \multicolumn{2}{|c|}{$\begin{array}{l}\text { TRICHLORO- } \\
\text { ETHYLENE }\end{array}$} & \multicolumn{2}{|c|}{$\begin{array}{l}\text { TETRACHLORO- } \\
\text { ETHYLENE }\end{array}$} & TOTA \\
\hline$A B G$ & 1 & $06 / 12 / 84$ & LT & 5 & & 13 & & 12 & 25 \\
\hline$A C$ & $1 \mathrm{~A}$ & $05 / 02 / 83$ & & 4 & LT & 1 & LT & 1 & 4 \\
\hline$A C$ & $1 \mathrm{~A}$ & $07 / 12 / 83$ & LT & 1 & LT & 1 & LT & 1 & 0 \\
\hline $\mathrm{AC}$ & 1B & $04 / 27 / 83$ & LT & 1 & LT & 12 & LT & 1 & D \\
\hline$A C$ & 1B & $07 / 12 / 83$ & LT & 1 & LI & $1^{-}$ & LT & 1 & $\mathbf{0}$ \\
\hline AC & $1 B$ & $06 / 18 / 84$ & LT & 5 & LT & $5 \checkmark$ & LT & 5 & 0 \\
\hline $\mathrm{AC}$ & $2 A$ & $04 / 23 / 83$ & LT & 1 & & 2 & LT & 1 & 2 \\
\hline $\mathrm{AC}$ & $2 \mathrm{~A}$ & $07 / 11 / 83$ & LT & 1 & & 2 & & 2 & 4 \\
\hline AC & $2 A$ & $06 / 13 / 84$ & LT & 5 & LT & $5^{\prime}$ & LT & 5 & $\mathbf{0}$ \\
\hline AC & 2B & $05 / 10 / 83$ & & 2 & & $4 \nearrow$ & LT & 1 & 6 \\
\hline $\mathrm{AC}$ & $2 B$ & $07 / 11 / 83$ & LT & 1 & LT & $1 ك$ & LT & 1 & 0 \\
\hline AC & 2B & $05 / 01 / 84$ & LT & 5 & LT & 5 & LT & 5 & 0 \\
\hline $\mathrm{AC}$ & $3 \mathrm{~A}$ & $04 / 29 / 83$ & & 1 & & 1 & & 1 & 3 \\
\hline AC & $3 A$ & $07 / 12 / 83$ & LT & 1 & LT & $1-$ & LT & 1 & 0 \\
\hline AC & $\mathbf{3 A}$ & $06 / 07 / 84$ & LT & 5 & LT & 5 & LT & 5 & 0 \\
\hline $\mathrm{AC}$ & 3B & $04 / 29 / 83$ & & 1 & & 1. & & 1 & 3 \\
\hline $\mathrm{AC}$ & 3B & $07 / 12 / 83$ & LI & 1 & $L T$ & $1 \checkmark$ & LT & 1 & 0 \\
\hline AC & 3B & $06 / 07 / 84$ & LT & 5 & $\mathbf{L T}$ & $\mathbf{5}^{2}$ & LT & 5 & 0 \\
\hline AMB & 2 & $06 / 11 / 84$ & LI & 5 & & $161 /$ & LT & 5 & 161 \\
\hline$A O B$ & 1 & $06 / 11 / 84$ & LT & 5 & & $169 \checkmark$ & & 126 & 295 \\
\hline$A O B$ & 2 & $06 / 11 / 84$ & LT & 5 & LT & $5 \checkmark$ & LT & 5 & 0 \\
\hline ASB & 3 & $05 / 14 / 84$ & LT & 5 & & $7-$ & LT & 5 & 7 \\
\hline ASB & 4 & $06 / 12 / 84$ & LI & 5 & & 17 & LT & 5 & 17 \\
\hline ASB & 7 & $05 / 14 / 84$ & LT & 5 & LT & 5 & & 5 & 5 \\
\hline ASB & 8 & $05 / 30 / 84$ & LT & 5 & & 1340 & LT & 5 & 1340 \\
\hline ASB & 9 & $06 / 20 / 84$ & LT & 5 & LT & 5 & LT & 5 & 0 \\
\hline MSB & $1 \mathrm{~A}$ & $07 / 16 / 83$ & & 2 & & 125 & & 85 & 212 \\
\hline MSB & $1 \mathrm{~A}$ & $07 / 16 / 83$ & & 6 & & 133 & & 84 & 223 \\
\hline MSB & $1 \mathrm{~A}$ & $05 / 03 / 84$ & LT & 5 & & 194 & & 85 & 279 \\
\hline MSB & $2 \mathrm{~A}$ & $07 / 16 / 83$ & & 33 & & 1300 & & 1014 & 2347 \\
\hline MSB & $2 \mathrm{~A}$ & $05 / 03 / 84$ & LT & 5 & & 303 & & 178 & 481 \\
\hline MSB & $3 A$ & $06 / 06 / 83$ & & . & & $87400^{-1}$ & & 33500 & \\
\hline MSB & $3 A$ & $07 / 16 / 83$ & LT & - & & 61000 & & 69000 & 430000 \\
\hline MSB & $3 A$ & $05 / 03 / 84$ & & 45 & & 15000 & & 27000 & 542045 \\
\hline MSB & $4 \mathrm{~A}$ & $07 / 16 / 83$ & & 47 & & $402^{\prime}$ & & 617 & 1066 \\
\hline MSB & $4 \mathrm{~A}$ & $05 / 03 / 84$ & & 203 & & 453 & & 1910 & 2566 \\
\hline MSB & $5 \mathrm{~A}$ & $07 / 16 / 83$ & & 42 & & $3 r$ & & 69 & 114 \\
\hline MSB & $5 \mathrm{~A}$ & $05 / 10 / 84$ & & 25 & L.T & $5^{\prime}$ & & 34 & 59 \\
\hline MSB & $6 \mathrm{~A}$ & $07 / 16 / 83$ & & 1 & LT & 12 & LT & 1 & 1 \\
\hline MSB & $6 \mathrm{~A}$ & $05 / 10 / 84$ & LT & 5 & LT & 5 & LT & 5 & 0 \\
\hline MSB & $7 \mathrm{~A}$ & $07 / 16 / 83$ & & 46 & & 3 & & 27 & 76 \\
\hline MSB & $7 \mathrm{~A}$ & $05 / 10 / 84$ & & 25 & LT & $5 \checkmark$ & LT & 5 & 25 \\
\hline MSB & $8 \mathrm{~A}$ & $07 / 16 / 83$ & & 6 & & 95 - & & 149 & 250 \\
\hline MSB & $8 \mathrm{~A}$ & $05 / 10 / 84$ & LT & 5 & & $83 v$ & & 246 & 329 \\
\hline MSB & $9 \mathrm{~A}$ & $04 / 24 / 83$ & LT & 1 & & $104 \checkmark$ & & 3 & 107 \\
\hline MSB : & $9 A$ & $06 / 03 / 83$ & & . & & $179^{\prime}$ & & 7 & \\
\hline MSB & $9 A$ & $07 / 07 / 83$ & LT & 1 & & 207 & & 7 & 214 \\
\hline MSB & $9 A$ & $04 / 13 / 84$ & L.T & 5 & & $432 r$ & & 10 & 442 \\
\hline MSB & $9 B$ & $06 / 03 / 83$ & L.T & 1 & & 204 & & 274 & 478 \\
\hline
\end{tabular}


. APPENDIX B. CONCENTRATIONS OF DEGREASER SOLVENTS IN WATER FROM

- WELLS REPORTED IN MICROGRAMS PER LITER (PPB).

\begin{tabular}{|c|c|c|c|c|c|c|c|c|c|}
\hline \multicolumn{2}{|c|}{. WELL } & \multirow{2}{*}{$\begin{array}{c}\text { SAMPLE } \\
\text { DATE } \\
06 / 29 / 83\end{array}$} & $1,1,1$ & \multirow{2}{*}{$\begin{array}{l}\text { TCE } \\
10\end{array}$} & \multicolumn{2}{|c|}{$\begin{array}{l}\text { TRICHLORO- } \\
\text { ETHYLENE }\end{array}$} & \multicolumn{2}{|c|}{$\begin{array}{l}\text { TETRACHLORO- } \\
\text { ETHXLENE }\end{array}$} & \multirow{2}{*}{$\begin{array}{c}\text { TOTAL } \\
398\end{array}$} \\
\hline$\dot{M S B}$ & $9 B$ & & & & & $188^{-}$ & & 200 & \\
\hline MSB & $9 B$ & $06 / 29 / 83$ & & 8 & & 194 & & 199 & 401 \\
\hline MSB & 9B & $04 / 17 / 84$ & LT & 5 & & $143 \checkmark$ & & 37 & 180 \\
\hline MSB & $9 \mathrm{c}$ & $05 / 16 / 83$ & & 10 & & 495 & & 1280 & 1785 \\
\hline MSB & $9 \mathrm{C}$ & $06 / 02 / 83$ & & . & & 533 & & 258 & • \\
\hline MSB & 9C & $06 / 02 / 83$ & & . & & 556 & & 259 & \\
\hline MSB & $9 \mathrm{C}$ & $06 / 29 / 83$ & & 41 & & $1264^{-}$ & & 1267 & 2572 \\
\hline MSB & $9 \mathrm{C}$ & $04 / 16 / 84$ & & 29 & & $11000^{\checkmark}$ & & 3770 & 14799 \\
\hline MSB & $10 \mathrm{~A}$ & $04 / 24 / 83$ & LT & 1 & LT & 1 & LT & 1 & 0 \\
\hline MSB & $10 \mathrm{~A}$ & $04 / 17 / 84$ & LT & 5 & LI & 5 & LT & 5 & o \\
\hline MSB & $10 \mathrm{~B}$ & $05 / 26 / 83$ & & 2 & & 33 & & 1 & 36 \\
\hline MSB & $10 B$ & $06 / 27 / 83$ & LT & 1 & & 8 & LI & 1 & 8 \\
\hline MSB & $10 B$ & $07 / 07 / 83$ & LT & 1 & & 32 & LT & 1 & 3 \\
\hline MSB & $10 \mathrm{~B}$ & $04 / 18 / 84$ & LT & 5 & LT & 5. & LT & 5 & 0 \\
\hline MSB & $10 \mathrm{C}$ & $04 / 24 / 83$ & & 5 & & 113 & & 540 & 658 \\
\hline MSB & $10 \mathrm{C}$ & $07 / 07 / 83$ & LT & 1 & & $132^{\prime}$ & & 413 & 545 \\
\hline MSB & $10 \mathrm{C}$ & $04 / 18 / 84$ & LT & 5 & & $175^{\prime}$ & & 313 & 488 \\
\hline MSB & 10D & $06 / 17 / 83$ & LT & 1 & & 156 & & 79 & 235 \\
\hline MSB & $11 \mathrm{~A}$ & $04 / 24 / 83$ & LT & 1 & & 98 & & 4 & 102 \\
\hline MSB & $11 \mathrm{~A}$ & $05 / 25 / 83$ & & 1 & & 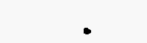 & & 7 & . \\
\hline MSB & $11 \mathrm{~A}$ & $06 / 27 / 83$ & & 2 & & $67-$ & & 3 & 72 \\
\hline MSB & $11 \mathrm{~A}$ & $04 / 12 / 84$ & LT & 5 & & $20=$ & LT & 5 & 20 \\
\hline MSB & $11 \mathrm{~B}$ & $05 / 24 / 83$ & & 2 & & 263 & & 107 & 372 \\
\hline MSB & $11 \mathrm{~B}$ & $06 / 28 / 83$ & LT & 1 & & $464^{\circ}$ & & 30 & 494 \\
\hline MSB & $11 \mathrm{~B}$ & $04 / 12 / 84$ & LT & 5 & & 138 & & 7 & 145 \\
\hline MSB & $11 \mathrm{C}$ & $05 / 24 / 83$ & & 2 & & 38500 & LT & 100 & 38502 \\
\hline MSB & $11 \mathrm{C}$ & $06 / 28 / 83$ & & 13 & & 22000 . & & 11 & 22024 \\
\hline MSB & $11 \mathrm{C}$ & $04 / 12 / 84$ & LI & 5 & & 34000 . & LT & 5 & 34000 \\
\hline MSB & 110 & $05 / 24 / 83$ & LT & 1 & & 6130 & & 180 & 6310 \\
\hline MSB & $11 \mathrm{D}$ & $06 / 27 / 83$ & LT & 1 & & 34000 & & 56 & 34056 \\
\hline MSB & 110 & $04 / 12 / 84$ & LT & 5 & & 7340 & & 866 & 8206 \\
\hline MSB & $11 \mathrm{~F}$ & $06 / 17 / 83$ & & 5 & & 22200 & & 3970 & 26175 \\
\hline MSB & $11 \mathrm{~F}$ & $07 / 07 / 83$ & LT & 1 & & 50000 & & 3300 & 53300 \\
\hline MSB & $11 \mathrm{~F}$ & $04 / 12 / 84$ & LT & 5 & & 17900 & & 2670 & 20570 \\
\hline MSB & $12 \mathrm{~A}$ & $05 / 24 / 83$ & & 3 & & 86 & LT & 1 & 89 \\
\hline MSB & $12 \mathrm{~A}$ & $06 / 27 / 83$ & LT & 1 & & 118 & LI & 1 & 118 \\
\hline MSB & $12 \mathrm{~A}$ & $04 / 19 / 84$ & LT & 5 & & 137 & LT & 5 & 137 \\
\hline MSB & $12 B$ & $04 / 27 / 83$ & & 225 & & 30 & & 537 & 792 \\
\hline MSB & 12B & $07 / 07 / 83$ & & 237 & & 39 & & 270 & 546 \\
\hline MSB & 12B & $04 / 19 / 84$ & & 509 & & 15 & & 147 & 671 \\
\hline MSB & $12 \mathrm{C}$ & $04 / 27 / 83$ & & 233 & & 16 & & 529 & 778 \\
\hline MSB & $12 \mathrm{C}$ & $07 / 07 / 83$ & & 257 & & 29 & & 262 & 548 \\
\hline MSB & $12 \mathrm{C}$ & $04 / 18 / 84$ & & 282 & & 37 & & 223 & 542 \\
\hline MSB & $12 \mathrm{D}$ & $06 / 16 / 83$ & & 3 & LT & 1 & LT & 1 & 3 \\
\hline MSB & 12D & $07 / 07 / 83$ & & 3 & LT & 1 & LT & 1 & 3 \\
\hline MSB & 12D & $07 / 07 / 83$ & & 3 & LT & 1 & $\mathbf{L T}$ & 1 & 3 \\
\hline MSB & $12 \mathrm{D}$ & $04 / 18 / 84$ & LT & 5 & LT & $\mathbf{5}^{\prime}$ & LT & 5 & 0 \\
\hline MSB & $12 \mathrm{TA}$ & $10 / 24 / 83$ & LT & 1 & LT & 1 & LT & 1 & o \\
\hline MSB & $12 \mathrm{TA}$ & $10 / 25 / 83$ & LT & 1 & $\mathbf{L T}$ & 1 & LT & 1 & 0 \\
\hline
\end{tabular}


. APPENDIX B. CONCENTRATIONS OF DEGREASER SOLVENTS IN WATER FROM HELLS REPORTED IN MICROGRAMS PER LITER (PPB).

\begin{tabular}{|c|c|c|c|c|c|c|c|c|c|}
\hline \multicolumn{2}{|c|}{. WELL } & $\begin{array}{l}\text { SAMPLE } \\
\text { DATE }\end{array}$ & $1,1,1$ & TCE & \multicolumn{2}{|c|}{$\begin{array}{l}\text { TRICHLORO- } \\
\text { ETHYLENE }\end{array}$} & \multicolumn{2}{|c|}{$\begin{array}{l}\text { TETRACHLORO- } \\
\text { ETHYLENE }\end{array}$} & \multirow{2}{*}{$\begin{array}{r}\text { TOTAL } \\
0\end{array}$} \\
\hline MSB & $12 \mathrm{TA}$ & $10 / 26 / 83$ & LT & 1 & LT & $1 \checkmark$ & LT & 1 & \\
\hline MSB & $12 \mathrm{TA}$ & $05 / 22 / 84$ & LT & 1 & LT & 1 & LT & 1 & 0 \\
\hline MSB & $12 \mathrm{TA}$ & $05 / 25 / 84$ & LT & 5 & LT & 5 & LT & Б & 0 \\
\hline MSB & $12 \mathrm{TA}$ & $06 / 19 / 84$ & LT & 5 & LT & $5^{\prime}$ & LT & 5 & 0 \\
\hline MSB & $12 \mathrm{~TB}$ & $10 / 24 / 83$ & LT & 1 & LT & 12 & LT & 1 & 0 \\
\hline MSB & $12 \mathrm{~TB}$ & $10 / 25 / 83$ & LT & 1 & LT & 1 & LT & 1 & 0 \\
\hline MSB & $12 \mathrm{~TB}$ & $10 / 25 / 83$ & LT & 1 & LT & 1. & LT & 1 & 0 \\
\hline MSB & $12 \mathrm{~TB}$ & $10 / 26 / 83$ & $\mathbf{L T}$ & 1 & LT & 12 & LT & 1 & 0 \\
\hline MSB & $12 \mathrm{~TB}$ & $05 / 17 / 84$ & LT & 5 & & $\mathbf{N}$ & LT & $\mathbf{5}$ & - \\
\hline MSB & $12 \mathrm{~TB}$ & $06 / 19 / 84$ & $\mathbf{L T}$ & $\mathbf{5}$ & $\mathbf{L T}$ & $5 \checkmark$ & LT & 5 & 0 \\
\hline MSB & $13 \mathrm{~A}$ & $04 / 28 / 83$ & & 2 & & $1^{\prime}$ & & 1 & 4 \\
\hline MSB & $13 A$ & $07 / 12 / 83$ & LT & 1 & LT & $1^{2}$ & LT & 1 & 0 \\
\hline MSB & $13 A$ & $04 / 20 / 84$ & LT & 5 & LT & 5 & $\mathbf{L T}$ & 5 & 0 \\
\hline MSB & 13B & $06 / 03 / 83$ & & 16 & & 39 & & 88 & 143 \\
\hline MSB & $13 \mathrm{~B}$ & $07 / 05 / 83$ & LT & 1 & & $75 \checkmark$ & & 155 & 230 \\
\hline MSB & 138 & $04 / 20 / 84$ & LT & 5 & & $76 \checkmark$ & & 14 & 90 \\
\hline MSB & $13 \mathrm{C}$ & $04 / 28 / 83$ & & 186 & & $5-$ & & 17 & 208 \\
\hline MSB & $13 C$ & $07 / 12 / 83$ & & 97 & & $38>$ & & 12 & 147 \\
\hline MSB & $13 C$ & $04 / 20 / 84$ & & $\mathbf{5}$ & & $6 r$ & & 9 & 20 \\
\hline MSB & $14 \mathrm{~A}$ & $06 / 16 / 83$ & & 6 & & $954 \checkmark$ & & 77 & 1037 \\
\hline MSB & $14 \mathrm{~A}$ & $07 / 11 / 83$ & & 1 & & $938 \checkmark$ & & 98 & 1037 \\
\hline MSB & $14 \mathrm{~A}$ & $06 / 14 / 84$ & LT & 5 & & $732 \checkmark$ & & 79 & 811 \\
\hline MSB & $14 \mathrm{~B}$ & $05 / 25 / 83$ & & 3 & & $320 r$ & & 400 & 723 \\
\hline MSB & $14 \mathrm{~B}$ & $06 / 29 / 83$ & & 10 & & $264 \checkmark$ & & 304 & 578 \\
\hline MSB & $14 B$ & $04 / 13 / 84$ & LT & $\mathbf{6}$ & & $225 \checkmark$ & & 346 & 571 \\
\hline MSB & $14 C$ & $04 / 27 / 83$ & & 63 & & $11 /$ & & 6 & 80 \\
\hline MSB & $14 \mathrm{C}$ & $07 / 11 / 83$ & & 50 & & $15 \sim$ & & 6 & 71 \\
\hline MSB & $14 C$ & $04 / 13 / 84$ & & 32 & & $15 \checkmark$ & & 7 & 54 \\
\hline MSB & $15 A$ & $04 / 28 / 83$ & & 4 & & $2350 \checkmark$ & & 2 & 2356 \\
\hline MSB & $15 \mathrm{~A}$ & $05 / 26 / 83$ & & 7 & & 2840 & & 4 & 2851 \\
\hline MSB & $15 \mathrm{~A}$ & $06 / 27 / 83$ & LT & 1 & & $2700 v$ & LT & 1 & 2700 \\
\hline MSB & $15 \mathrm{~A}$ & $04 / 16 / 84$ & LI & 5 & & 2370 & LT & $\mathbf{5}$ & 2370 \\
\hline MSB & $16 \mathrm{~A}$ & $04 / 23 / 83$ & & 3 & & 1620 & & 4 & 1627 \\
\hline MSB & $16 \mathrm{~A}$ & $05 / 25 / 83$ & & 7 & & $1980 \checkmark$ & & 3 & 1990 \\
\hline MSB & $16 A$ & $06 / 27 / 83$ & & $\mathbf{N}$ & & $\mathbf{N}$ & & $\mathbf{N}$ & - \\
\hline MSB & $16 \mathrm{~A}$ & $04 / 17 / 84$ & $\mathbf{L T}$ & 5 & & 1430 & & 5 & 1435 \\
\hline MSB & $16 C$ & $04 / 24 / 83$ & & 3 & & 9630 & & 1140 & 10773 \\
\hline MSB & $16 \mathrm{C}$ & $05 / 26 / 83$ & & 34 & & $10000^{\checkmark}$ & & 693 & 10727 \\
\hline MSB & $16 C$ & $06 / 28 / 83$ & & 9 & & $1000 /$ & & 676 & 11685 \\
\hline $\mathrm{MSB}$ & $16 \mathrm{C}$ & $04 / 17 / 84$ & LT & $\mathbf{5}$ & & $4980 \checkmark$ & & 733 & 5713 \\
\hline $\mathrm{MSB}$ & $17 \mathrm{~A}$ & $04 / 28 / 83$ & & 171 & & $62 \checkmark$ & & 335 & 568 \\
\hline MSB & $17 \mathrm{~A}$ & $07 / 11 / 83$ & LT & 1 & & $131 \checkmark$ & & 500 & 631 \\
\hline MSB & $17 \mathrm{~A}$ & $04 / 23 / 84$ & LT & 5 & & $50 \sim$ & & 791 & 841 \\
\hline MSB & 178 & $04 / 29 / 83$ & & 38 & & $28 \checkmark$ & & 273 & 339 \\
\hline MSB & $17 B$ & $07 / 11 / 83$ & & $\mathbf{5 1}$ & & $28 \Upsilon$ & & 380 & 459 \\
\hline MSB & $17 \mathrm{~B}$ & $04 / 24 / 84$ & & 124 & LT & $5 \swarrow$ & & 641 & 765 \\
\hline MSB & $18 \mathrm{~A}$ & $06 / 02 / 83$ & LT & 1 & & $8^{\prime}$ & LT & 1 & 8 \\
\hline MSB & $18 \mathrm{~A}$ & $06 / 28 / 83$ & & 1 & & $9^{2}$ & LT & 1 & 10 \\
\hline MSB & $18 \mathrm{~A}$ & $06 / 28 / 83$ & & 1 & & & LT & 1 & 10 \\
\hline
\end{tabular}


. APPENDIX B. CONCENTRATIONS OF DEGREASER SOLVENTS IN WATER FROM WELLS REPORTED IN MICROGRAMS PER LITER (PPB).

\begin{tabular}{|c|c|c|c|c|c|c|c|c|c|}
\hline \multicolumn{2}{|c|}{. HELL } & $\begin{array}{c}\text { SAMPLE } \\
\text { DATE }\end{array}$ & $1,1,1$ & TCE & \multicolumn{2}{|c|}{$\begin{array}{l}\text { TRICHLORO- } \\
\text { ETIYLENE }\end{array}$} & \multicolumn{2}{|c|}{$\begin{array}{l}\text { TETRACHLORO- } \\
\text { ETHYLENE }\end{array}$} & \multirow{2}{*}{$\begin{array}{r}\text { TOTAI } \\
\mathbf{8}\end{array}$} \\
\hline MSB & $18 \mathrm{~A}$ & $04 / 23 / 84$ & LT & 5 & & $8^{-}$ & LT & 5 & \\
\hline MSB & $18 B$ & $04 / 28 / 83$ & & 71 & & $2^{\prime}$ & & 47 & 120 \\
\hline MSB & $18 B$ & $07 / 12 / 83$ & & 31 & & 5 & & 43 & 79 \\
\hline MSB & $18 \mathrm{~B}$ & $04 / 23 / 84$ & & 27 & & 5 & & 15 & 47 \\
\hline MSB & $18 \mathrm{C}$ & $04 / 28 / 83$ & & 1 & & 12 & & 1 & 3 \\
\hline MSB & $18 \mathrm{C}$ & $07 / 12 / 83$ & & 2 & LT & $1-$ & LT & 1 & 2 \\
\hline MSB & $18 \mathrm{C}$ & $07 / 12 / 83$ & & 1 & LT & 1) & LT & 1 & 1 \\
\hline MSB & $18 \mathrm{C}$ & $04 / 23 / 84$ & LI & 5 & LT & 5 & LT & 5 & o \\
\hline MSB & $19 \mathrm{~A}$ & $04 / 30 / 83$ & & 5 & & 104 & LT & 1 & 109 \\
\hline MSB & $19 \mathrm{~A}$ & $07 / 08 / 83$ & & 2 & & 110 & LT & 1 & 112 \\
\hline MSB & $19 \mathrm{~A}$ & $06 / 08 / 84$ & LT & 5 & & $111 \checkmark$ & $\mathbf{L T}$ & 5 & 111 \\
\hline MSB & $19 B$ & $06 / 08 / 83$ & LT & 1 & & 468 & & 484 & 952 \\
\hline MSB & $19 \mathrm{~B}$ & $06 / 08 / 83$ & LI & 1 & & 453 & & 487 & 940 \\
\hline MSB & $19 B$ & $07 / 11 / 83$ & LT & 1 & & $191 \checkmark$ & & 5 & 196 \\
\hline MSB & $19 B$ & $06 / 08 / 84$ & LT & 5 & & 195 & LT & 5 & 195 \\
\hline MSB & $19 \mathrm{C}$ & $04 / 30 / 83$ & & 2 & & 195 - & & 8 & 205 \\
\hline MSB & $19 C$ & $07 / 11 / 83$ & LT & 1 & & $313 \checkmark$ & & 17 & 330 \\
\hline MSB & $19 C$ & $06 / 13 / 84$ & LT & 5 & & 808 - & & 153 & 961 \\
\hline MSB & $20 \mathrm{~A}$ & $04 / 23 / 83$ & LT & 1 & & 4 & LT & 1 & 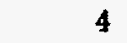 \\
\hline MSB & $20 \mathrm{~A}$ & $04 / 27 / 83$ & LT & 1 & & 5 & LT & 1 & $\mathbf{b}$ \\
\hline MSB & $20 \mathrm{~A}$ & $06 / 08 / 83$ & LT & 1 & & $5 \checkmark$ & LT & 1 & 5 \\
\hline MSB & $20 \mathrm{~A}$ & $07 / 06 / 83$ & LT & 1 & & 7 & $\mathbf{L T}$ & 1 & 7 \\
\hline MSB & $20 \mathrm{~A}$ & $07 / 06 / 83$ & LT & 1 & & 70 & LT & 1 & 7 \\
\hline MSB & $20 \mathrm{~A}$ & $04 / 24 / 84$ & LT & 5 & & $19 \checkmark$ & LT & 5 & 19 \\
\hline MSB & $20 \mathrm{~A}$ & $04 / 24 / 84$ & LT & 5 & & 7 & $\mathbf{L T}$ & 5 & 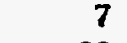 \\
\hline MSB & $20 \mathrm{C}$ & $04 / 23 / 83$ & LT & 1 & & $69-$ & LT & 1 & 69 \\
\hline MSB & $20 \mathrm{C}$ & $04 / 27 / 83$ & LT & 1 & & $505 \checkmark$ & LT & 1 & 505 \\
\hline MSB & $20 \mathrm{C}$ & $06 / 08 / 83$ & & 1 & & 443r & LT & 1 & 444 \\
\hline MSB & $20 \mathrm{C}$ & $07 / 06 / 83$ & & 1 & & 338 & LT & 1 & 339 \\
\hline MSB & $20 \mathrm{C}$ & $04 / 24 / 84$ & LT & $\mathbf{5}$ & & ธ9 & LT & 5 & 59 \\
\hline MSB & $21 \mathrm{~A}$ & $04 / 23 / 83$ & LT & 1 & & $5 /$ & LT & 1 & 5 \\
\hline MSB & $21 \mathrm{~A}$ & $07 / 11 / 83$ & $\mathbf{L T}$ & 1 & & 3 & LT & 1 & 3 \\
\hline MSB & $21 \mathrm{~A}$ & $04 / 25 / 84$ & LI & 5 & LT & 5 & LT & 5 & 0 \\
\hline MSB & $21 \mathrm{C}$ & $04 / 23 / 83$ & & 1 & LT & 12 & LT & 1 & 1 \\
\hline MSB & $21 \mathrm{C}$ & $07 / 11 / 83$ & LT & 1 & LT & $1 \checkmark$ & LT & 1 & o \\
\hline MSB & $21 \mathrm{C}$ & $04 / 24 / 84$ & LT & 5 & LT & 52 & $\mathbf{L T}$ & 5 & 0 \\
\hline MSB & 22 & $05 / 24 / 83$ & & 2 & & 000 & & 85000 & 152002 \\
\hline MSB & 22 & $06 / 27 / 83$ & & 2 & & 1000 & & 94000 & 173002 \\
\hline MSB & 22 & $04 / 13 / 84$ & LT & 5 & & $1600 \Omega$ & & 36700 & 57300 \\
\hline MSB & 23 & $05 / 09 / 83$ & LT & 1 & & 0002 & & 6800 & 129800 \\
\hline MSB & 23 & $06 / 01 / 83$ & & $\mathbf{N}$ & & $500 \checkmark$ & & 5240 & \\
\hline MSB & 23 & $06 / 07 / 83$ & & 1 & & 1000 & & 5600 & 55601 \\
\hline MSB & 23 & $07 / 06 / 83$ & & 1 & & 10002 & & 4900 & 53901 \\
\hline MSB & 23 & $05 / 11 / 84$ & LT & 5 & & 000 & & 1590 & 28590 \\
\hline MSB & $23 \mathrm{~A}$ & $04 / 11 / 83$ & LT & 1 & LT & 12 & LT & 1 & 0 \\
\hline MSB & $23 \mathrm{~A}$ & $05 / 09 / 83$ & LT & 1 & LT & $1-$ & LT & 1 & 促 \\
\hline MSB & $23 \mathrm{~A}$ & $06 / 07 / 83$ & & 3 & $\mathbf{L T}$ & 12 & LT & 1 & 3 \\
\hline MSB & $23 A$ & $07 / 06 / 83$ & LT & 1 & LT & 1 & LT & 1 & \\
\hline MSB & $23 \mathrm{~A}$ & $05 / 11 / 84$ & LI & 5 & $\mathbf{L T}$ & 5 & LT & 5 & \\
\hline
\end{tabular}


.APPENDIX B. CONCENTRATIONS OF DEGREASER SOLVENTS IN WATER FROM WELLS REPORTED IN MICROGRAMS PER LITER (PPB).

\begin{tabular}{|c|c|c|c|c|c|c|c|c|}
\hline . WELL & $\begin{array}{c}\text { SAMPLE } \\
\text { DATE }\end{array}$ & $1,1,1$ & TCE & \multicolumn{2}{|c|}{$\begin{array}{l}\text { TRICHLORO- } \\
\text { ETHYLENE }\end{array}$} & \multicolumn{2}{|c|}{$\begin{array}{l}\text { TETRACHLORO- } \\
\text { ETHYLENE }\end{array}$} & \multirow{2}{*}{$\begin{array}{r}\text { TOTAL } \\
\mathbf{0}\end{array}$} \\
\hline MSB 23A & $05 / 29 / 84$ & LT & 5 & LT & 5 & LT & 5 & \\
\hline MSB 23A & $06 / 05 / 84$ & $\mathrm{LT}$ & 1 & LI & 1 & LT & 1 & 0 \\
\hline MSB $23 A$ & $06 / 26 / 84$ & LT & 5 & LT & 5 & LT & 5 & $\mathbf{0}$ \\
\hline MSB 23A & $06 / 26 / 84$ & LT & 5 & LI & 5 & LT & 5 & 0 \\
\hline MSB 23A & $06 / 27 / 84$ & LT & 5 & & 181 & LT & $\mathbf{5}$ & 181 \\
\hline MSB 23A & $06 / 27 / 84$ & LT & 5 & & 163 & LT & $\mathbf{6}$ & 163 \\
\hline MSB 23A & $07 / 10 / 84$ & $\mathrm{LT}$ & 1 & & $497^{\circ}$ & & 6 & 503 \\
\hline MSB 23A & $07 / 10 / 84$ & $\mathrm{LT}$ & 1 & & $499^{\prime}$ & & 7 & 506 \\
\hline MSB 23B & $05 / 09 / 83$ & LT & 1 & & $78000^{\circ}$ & & 1390 & 79330 \\
\hline MSB 23B & $06 / 01 / 83$ & & N & & 46200 & & 2060 & 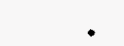 \\
\hline MSB 23B & $07 / 06 / 83$ & LT & 1 & & $36000 \Omega$ & & 510 & 36510 \\
\hline MSB 23B & $05 / 11 / 84$ & LT & 5 & & $15000^{\prime}$ & & 144 & 15144 \\
\hline MSB 24 & $06 / 02 / 83$ & & 87 & & $11700^{\circ}$ & & 788 & 12575 \\
\hline MSB 24 & $07 / 07 / 83$ & & 48 & & 14000 & & 280 & 14328 \\
\hline MSB 24 & $05 / 15 / 84$ & LT & 5 & & $9980 \checkmark$ & & 598 & 10578 \\
\hline MSB $24 A$ & $04 / 29 / 83$ & & 1 & & $15010^{\prime}$ & & 108 & 15119 \\
\hline MSB $24 A$ & $06 / 01 / 83$ & & 78 & & $41100^{\prime}$ & & 350 & 41528 \\
\hline MSB 24A & $07 / 07 / 83$ & $\mathbf{L T}$ & 1 & & $9900^{\prime}$ & & 175 & 10075 \\
\hline MSB 24A & $05 / 15 / 84$ & LT & 5 & LT & $5 \checkmark$ & LT & $\mathbf{5}$ & 0 \\
\hline MSB 25 & $05 / 16 / 83$ & & 3 & & 1150 & & 181 & 1334 \\
\hline MSB 25 & $07 / 12 / 83$ & L.T & 1 & & 2400 & & 146 & 2546. \\
\hline MSB 25 & $05 / 15 / 84$ & $\mathbf{L T}$ & 5 & & $1730^{\circ}$ & & 142 & 1872 \\
\hline MSB 25A & $05 / 16 / 83$ & & 3 & & $3150 八$ & & 24 & 3177 \\
\hline MSB 25A & $07 / 12 / 83$ & LT & 1 & & $4900 \swarrow$ & & 26 & 4926 \\
\hline MSB 25A & $05 / 15 / 84$ & LT & 5 & & 2910 & & 22 & 2932 \\
\hline MSB 26 & $05 / 10 / 83$ & LT & 1 & & $30 r$ & LT & 1 & 30 \\
\hline MSB 26 & $07 / 11 / 83$ & & 1 & & $34 \checkmark$ & LT & 1 & 35 \\
\hline MSB 26 & $04 / 26 / 84$ & LT & 5 & & $19<$ & LT & 5 & 19 \\
\hline MSB $26 \mathrm{~A}$ & $05 / 10 / 83$ & & 2 & & $22000 \checkmark$ & & 402 & 22404 \\
\hline MSB 26A & $07 / 11 / 83$ & & 67 & & $21000 \checkmark$ & & 195 & 21262 \\
\hline MSB 26A & $04 / 26 / 84$ & LT & 5 & & 33500 & & 297 & 33797 \\
\hline MSB 27 & $05 / 16 / 83$ & LT & 1 & LT & $1 \checkmark$ & LT & 1 & 0 \\
\hline MSB 27 & $06 / 10 / 83$ & & - & & $1 \gamma$ & & - & • \\
\hline MSB 27 & $07 / 11 / 83$ & LI & 1 & & $1 r$ & LT & 1 & 1 \\
\hline MSB 27 & $04 / 26 / 84$ & LT & 5 & & $37 \checkmark$ & LT & 5 & 37 \\
\hline MSB 27A & $05 / 10 / 83$ & LT & 1 & & 53000 & & 753 & 53753 \\
\hline MSB 27A & $06 / 06 / 83$ & & 2 & & . & & 397 & 列 \\
\hline MSB 27A & $06 / 06 / 83$ & & 30 & & $48600^{\checkmark}$ & & 289 & 48919 \\
\hline MSB 27A & $07 / 11 / 83$ & $\mathbf{L T}$ & 100 & & 28000 & & 254 & 28254 \\
\hline MSB 27A & $06 / 13 / 84$ & $\mathbf{L T}$ & 5 & & 61400 & & 230 & 61630 \\
\hline MSB 28 & $05 / 12 / 83$ & & 1 & & 4 & LT & 1 & $\mathbf{5}$ \\
\hline MSB 28 & $07 / 11 / 83$ & & 1 & & $4^{r}$ & LT & 1 & 5 \\
\hline MSB 28 & $04 / 30 / 84$ & LT & 5 & LT & $5^{2}$ & LT & 5 & $\mathbf{0}$ \\
\hline MSB 28A & $05 / 12 / 83$ & & 2 & & 2350 & & 3 & 2355 \\
\hline MSB 28A & $07 / 11 / 83$ & LT & 1 & & $2400 \Omega$ & LT & 1 & 2400 \\
\hline MSB 28A & $04 / 30 / 84$ & LT & 5 & & $3470 \sim$ & $\mathrm{LT}$ & 5 & 3470 \\
\hline MSB 30A & $05 / 12 / 83$ & & 1 & LT & 1 & $\mathbf{L T}$ & 1 & 1 \\
\hline MSB $30 A$ & $05 / 31 / 83$ & LT & 1 & LT & $1 \%$ & LT & 1 & 0 \\
\hline MSB $30 \mathrm{~A}$ & $07 / 05 / 83$ & LT & 1 & LI & $1 /$ & $\mathrm{LT}$ & 1 - & $\mathbf{0}$ \\
\hline
\end{tabular}


. APPENDIX B. CONCENTRATIONS OF DEGREASER SOLVENTS IN WATER FROM

- WELLS REPORTED IN MICROGRAMS PER LITER (PPB).

\begin{tabular}{|c|c|c|c|c|c|c|c|c|}
\hline . HELL & $\begin{array}{c}\text { SAMPLE } \\
\text { DATE }\end{array}$ & 1,1 , & $1 \mathrm{TCE}$ & $\begin{array}{l}\text { TRI } \\
\text { ETH }\end{array}$ & $\begin{array}{l}\text { HLORO- } \\
\text { LENE }\end{array}$ & $\begin{array}{l}\text { TETR } \\
\text { ETHY }\end{array}$ & $\begin{array}{l}\text { ACHLORO- } \\
\text { ENE }\end{array}$ & TOTAI \\
\hline SB $30 A$ & $07 / 12 / 83$ & LT & 1 & LT & $1 \checkmark$ & LT & 1 & 0 \\
\hline MSB $30 \mathrm{~A}$ & $04 / 30 / 84$ & LT & 5 & & $5-$ & LT & 5 & $\mathbf{5}$ \\
\hline SB $30 A$ & $05 / 21 / 84$ & LT & 1 & LT & 1 & LT & 1 & 0 \\
\hline$S B \quad 30 A$ & $06 / 25 / 84$ & LT & 5 & LT & 5 & LT & 5 & . \\
\hline MSB $30 A$ & $06 / 25 / 84$ & LT & 5 & LT & $5^{\prime}$ & LT & 5 & 0 \\
\hline SB $30 C$ & $05 / 12 / 83$ & LT & 1 & & $8-$ & LT & 1 & 8 \\
\hline$S B \quad 30 C$ & $05 / 31 / 83$ & LT & 1 & & 5 & LT & 1 & \\
\hline MSB $30 \mathrm{C}$ & $07 / 05 / 83$ & LT & 1 & & 7 & LT & 1 & \\
\hline SB $30 C$ & $07 / 05 / 83$ & LT & 1 & & 7 & LT & 1 & \\
\hline MSB $30 \mathrm{C}$ & $04 / 30 / 84$ & LT & 5 & & $5 \checkmark$ & LT & 5 & \\
\hline MSB $31 \mathrm{~A}$ & $06 / 02 / 83$ & LT & 1 & LT & $1-$ & L.T & 1 & \\
\hline SB 31A & $06 / 29 / 83$ & LT & 1 & LT & $1-$ & LT & 1 & \\
\hline MSB $31 \mathrm{~A}$ & $10 / 10 / 83$ & LT & 1 & LT & 1 & LT & 1 & \\
\hline ASB $31 \mathrm{~A}$ & $10 / 10 / 83$ & LT & 1 & LT & 1 - & LT & 1 & \\
\hline $5 B \quad 31 A$ & $05 / 09 / 84$ & LT & 6 & LT & $5 v$ & LT & 5 & \\
\hline MSB $31 \mathrm{~A}$ & $05 / 22 / 84$ & LT & 1 & LT & $1 \curvearrowright$ & LT & 1 & 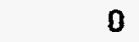 \\
\hline SB 31B & $06 / 01 / 83$ & & 1 & & 349 & & 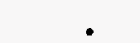 & . \\
\hline B 31B & $06 / 29 / 83$ & & $\mathbf{N}$ & & $\mathrm{N}$ & & $\mathbf{N}$ & \\
\hline ASB 31B & $08 / 31 / 83$ & L.T & 1 & & 278 & & 2 & 280 \\
\hline SB 31B & $09 / 01 / 83$ & LT & 1 & & 345 & & 51 & 396 \\
\hline B 31B & $05 / 09 / 84$ & LT & $\mathbf{N}$ & & 262 & LT & 5 & 262 \\
\hline SB 31C & $06 / 01 / 83$ & & & & $84000^{-}$ & & 33000 & \\
\hline SB 31C & $06 / 28 / 83$ & & 5 & & 05000 & & 90000 & 195005 \\
\hline SB 31C & $08 / 31 / 83$ & & 7 & & 35000 & & 06000 & 241007 \\
\hline B $31 \mathrm{C}$ & $09 / 01 / 83$ & & 6 & & 58000 & & 04000 & 362006 \\
\hline SB $31 \mathrm{C}$ & $05 / 09 / 84$ & & 12 & & $76500 \checkmark$ & & 83900 & 160412 \\
\hline B 32 & $05 / 02 / 83$ & & 5 & LT & $1 \%$ & LT & 1 & 5 \\
\hline SB 32 & $06 / 28 / 83$ & & 2 & LT & 12 & LT & 1 & 2 \\
\hline B 32 & $06 / 14 / 84$ & LT & 5 & LT & 52 & $\mathrm{LT}$ & 5 & 0 \\
\hline B 33 & $05 / 02 / 83$ & & 8 & & 131 & & 169 & 308 \\
\hline BB 33 & $06 / 28 / 83$ & & 5 & & 90 & & 93 & 188 \\
\hline 33 & $05 / 09 / 84$ & $\mathbf{L T}$ & 5 & & $178 \checkmark$ & & 102 & 280 \\
\hline B $34 \mathrm{~A}$ & $08 / 16 / 83$ & LT & 1 & & 650 r & & 38 & 688 \\
\hline $34 \mathrm{~A}$ & $08 / 23 / 83$ & $\mathbf{L T}$ & 1 & & 690 & & 38 & 728 \\
\hline $34 \mathrm{~A}$ & $08 / 25 / 83$ & $\mathbf{L T}$ & 1 & & 440 & & 33 & 473 \\
\hline $34 \mathrm{~A}$ & $08 / 27 / 83$ & LT & 1 & & 509 & & 39 & 548 \\
\hline B 34A & 09/08/83 & $\mathbf{L T}$ & 1 & & 703 & & 37 & 740 \\
\hline $34 \mathrm{~A}$ & $09 / 08 / 83$ & LT & 1 & & $703-$ & & 37 & 740 \\
\hline $34 \mathrm{~A}$ & $04 / 25 / 84$ & $\mathbf{L T}$ & $\mathbf{5}$ & & 607 - & & 35 & 642 \\
\hline $34 \mathrm{~B}$ & $08 / 16 / 83$ & & 12 & & $31000^{2}$ & & 5300 & 36312 \\
\hline ISB $34 \mathrm{~B}$ & $08 / 23 / 83$ & LT & 1 & & $28000^{\circ}$ & & 5400 & 33400 \\
\hline 34B & $08 / 25 / 83$ & $\mathbf{L T}$ & 1 & & $\mathbf{N}$ & & $N$ & \\
\hline $34 B$ & $08 / 27 / 83$ & LT & 1 & & 27000 & & 3600 & 30600 \\
\hline ISB $34 B$ & $09 / 08 / 83$ & $\mathbf{L T}$ & 1 & & 32500 & & 3000 & 35500 \\
\hline 34B & $09 / 08 / 83$ & LT & 1 & & 32500 & & 3000 & 35500 \\
\hline 34B & $04 / 25 / 84$ & $\mathbf{L T}$ & 5 & & $8480^{\circ}$ & & 1370 & 9850 \\
\hline $34 \mathrm{C}$ & $08 / 27 / 83$ & LT & 1 & & 29300 & & 4100 & 33400 \\
\hline $34 \mathrm{C}$ & $09 / 08 / 83$ & LT & 500 & & 48500 & & 5400 & 53900 \\
\hline $34 \mathrm{C}$ & $09 / 08 / 83$ & LT & 1 & & $48500^{-}$ & & 5400 & 53900 \\
\hline
\end{tabular}


. APPENDIX B. CONCENTRATIONS OF DEGREASER SOLVENTS IN WATER FROM WELLS REPORTED IN MICROGRAMS PER LITER (PPB).

\begin{tabular}{|c|c|c|c|c|c|c|c|c|c|}
\hline \multicolumn{2}{|c|}{.WELL } & $\begin{array}{l}\text { SAMPLE } \\
\text { DATE }\end{array}$ & $1,1,1$ & TCE & \multicolumn{2}{|c|}{$\begin{array}{l}\text { TRICHLORO- } \\
\text { ETHYLENE }\end{array}$} & \multicolumn{2}{|c|}{$\begin{array}{l}\text { TETRACHLORO- } \\
\text { ETHYLENE }\end{array}$} & \multirow{2}{*}{$\begin{array}{l}\text { TOTAL } \\
28010\end{array}$} \\
\hline MSB & $34 \mathrm{C}$ & $04 / 25 / 84$ & LT & 5 & & & & 3210 & \\
\hline MSB & 34TA & $08 / 08 / 83$ & LT & 1 & LT & $1 \checkmark$ & & 1 & 1 \\
\hline MSB & $34 \mathrm{TA}$ & $09 / 12 / 83$ & LT & 1 & LT & 12 & LT & 1 & 0 \\
\hline MSB & 34TA & $09 / 12 / 83$ & LT & 1 & LT & 12 & LT & 1 & 0 \\
\hline MSB & 34TA & $09 / 19 / 83$ & LT & 1 & LT & 18 & LI & 1 & D \\
\hline MSB & 34TA & $09 / 19 / 83$ & LT & 1 & LT & 10 & LT & 1 & 0 \\
\hline MSB & $34 \mathrm{TA}$ & $09 / 19 / 83$ & LT & 1 & $\mathbf{L T}$ & 12 & $\mathbf{L T}$ & 1 & 0 \\
\hline MSB & 34TA & $09 / 19 / 83$ & LT & 1 & LT & 15 & LT & 1 & 0 \\
\hline MSB & 34TA & $10 / 26 / 83$ & LT & 1 & LT & 1 & LT & 1 & 0 \\
\hline MSB & $34 \mathrm{TA}$ & $05 / 16 / 84$ & LT & 5 & & $\mathbf{N}$ & LT & 5 & . \\
\hline MSB & 34TA & $05 / 18 / 84$ & LT & 5 & LT & 5 & LT & 5 & 0 \\
\hline MSB & 34TA & $06 / 20 / 84$ & LT & $\mathbf{5}$ & LI & 5 & $\mathbf{L T}$ & 5 & 0 \\
\hline MSB & 34TA & $06 / 20 / 84$ & LT & 5 & LT & 5 & LT & 5 & D \\
\hline MSB & $34 \mathrm{~TB}$ & $09 / 08 / 83$ & LT & 1 & LT & $1^{2}$ & $\mathbf{L T}$ & 1 & 0 \\
\hline MSB & $34 \mathrm{~TB}$ & $09 / 08 / 83$ & LT & 1 & LT & 12 & LT & 1 & $\mathbf{0}$ \\
\hline MSB & $34 \mathrm{~TB}$. & $05 / 16 / 84$ & LT & 5 & LT & 5 & LT & 5 & 0 \\
\hline MSB & $34 \mathrm{~TB}$ & $05 / 18 / 84$ & LI & 5 & LT & 5 & LT & 5 & 0 \\
\hline MSB & 34TB & $06 / 21 / 84$ & LT & 5 & LT & 5 & LT & 5 & 0 \\
\hline MSB & $34 \mathrm{~TB}$ & $06 / 21 / 84$ & LT & 5 & LT & 5 & LT & 5 & 0 \\
\hline SRH & 1C & $05 / 04 / 84$ & LT & 5 & & 7 & & 27 & 34 \\
\hline SRH & $2 A$ & $05 / 02 / 84$ & LT & 5 & & $\mathbf{N}$ & & $N$ & . \\
\hline SRH & $2 \mathrm{~A}$ & $07 / 25 / 84$ & LT & 1 & LT & 12 & LT & 1 & 0 \\
\hline SRH & 2B & $05 / 02 / 84$ & LT & 5 & $\mathbf{L T}$ & $5^{2}$ & LT & 5 & 0 \\
\hline SRW & $2 C$ & $05 / 02 / 84$ & LT & 5 & L.T & 5 & LT & 5 & 0 \\
\hline SRH & $3 c$ & $05 / 02 / 84$ & LT & 5 & LT & $5^{\prime}$ & LT & 5 & $\mathbf{0}$ \\
\hline SRY & $4 C$ & $06 / 18 / 84$ & LT & 5 & LT & $5-$ & LT & 5 & 0 \\
\hline SRH & $5 C$ & $05 / 04 / 84$ & LT & 5 & & $6^{\prime}$ & & 9 & 15 \\
\hline SRW & $6 C$ & $05 / 04 / 84$ & LT & 5 & & $10^{\prime}$ & & 24 & 34 \\
\hline SRW & $9 \mathrm{~A}$ & $06 / 01 / 84$ & LT & 5 & LT & 5 & LT & 5 & 0 \\
\hline SRW & $9 \mathrm{~B}$ & $06 / 04 / 84$ & LT & 5 & LI & 5 & LT & 5 & 0 \\
\hline SRW & $12 A$ & $06 / 04 / 84$ & LT & 5 & LI & $5^{-}$ & LT & 5 & 0 \\
\hline SRW & $12 \mathrm{~B}$ & $06 / 04 / 84$ & LT & 5 & LT & $5^{\circ}$ & LT & 5 & 0 \\
\hline SRW & $12 \mathrm{C}$ & $06 / 06 / 84$ & LT & 5 & $\mathbf{L T}$ & 5 & LT & 5 & 0 \\
\hline SRH & $13 \mathrm{~A}$ & $05 / 31 / 84$ & LI & 5 & LT & $5^{3}$ & LT & 5 & 0 \\
\hline SRH & 13B & $05 / 31 / 84$ & LT & $\mathbf{5}$ & $\mathbf{L T}$ & 5 & LT & 5 & 0 \\
\hline SRW & $13 C$ & $06 / 01 / 84$ & LT & 5 & LT & 5 & LT & $\mathbf{5}$ & 0 \\
\hline SRW & $14 \mathrm{~A}$ & $05 / 07 / 84$ & LT & 5 & $\mathbf{L T}$ & $5^{2}$ & LT & $\mathbf{5}$ & 0 \\
\hline SRW & $14 B$ & $05 / 04 / 84$ & LT & 5 & LT & 5 & & 10 & 10 \\
\hline SRW & $14 C$ & $05 / 04 / 84$ & LT & 5 & $\mathbf{L T}$ & $5^{\prime}$ & & 8 & 8 \\
\hline SRW & $15 \mathrm{~A}$ & $05 / 07 / 84$ & LT & 5 & LT & 5 & LT & 5 & 0 \\
\hline SRW & $15 B$ & $05 / 07 / 84$ & LT & 5 & $\mathbf{L T}$ & $5^{\prime}$ & LT & 5 & 0 \\
\hline SRW & $15 C$ & $05 / 01 / 84$ & LT & 5 & LT & 5 & LT & 5 & 0 \\
\hline SRY & $16 \mathrm{~A}$ & $05 / 08 / 84$ & LT & 5 & LT & $5-$ & LT & $\mathbf{5}$ & 0 \\
\hline SRW & $16 B$ & $05 / 07 / 84$ & LT & 5 & LT & $5-$ & LT & $\mathbf{5}$ & 0 \\
\hline
\end{tabular}


The tables in this appendix give the analytes detected in water samples from each monitoring well as part of the M-Area plume definition program. Additional analytical results for wells MSB-1 through 8 collected as part of the quarterly monitoring program are given in Appendix D. The locations of these wells are shown on Figure 4-1 and construction details are given on Table 4-2. The units used are MG/L - milligrams per liter (PPM), UG/L - micrograms per liter (PPB), PC/L - picocuries per liter, UMHOS/CM - micromhos per centimeter, $\mathrm{PH}$ - $\mathrm{pH}$ units. The analytical methods used are gravimetric for the total dissolved solids, electrometer for $\mathrm{pH}$ and conductivity, wet chemistry of the ionic species, atomic absorption for metals, inductively coupled plasma erission spectroscopy for metals, gas chromatography and GC/MS for organic compounds, betagamma proportional counting for gross beta, and alpha scintillation counting for gross alpha and radium.

Analytes are arranged alphabetically across the top of the page in groups of nine to a page, and the wells are arranged alphabetically and numerically along the side of the page in eight pages before a new group of analytes is begun. The analyses of field blanks are given at the beginning of each list of wells.

Negative sign indicates that the concentration was below the limit of detectability which is indicated by the number following the negative sign. A dot indicates that no analysis was made for that analyte on that sample. The sampling protocol used for the 1983 analyses are described in Appendix E-1 and that for 1984 analyses in Appendix E-2. Because the $1983 \mathrm{~s}$ amples for metals analyses were not filtered, it is considered that the 1984 analyses are more reliable, and the 1983 analyses for metals should be considered with great caution.

The laboratories used are:

Envirodyne Engineers, Inc. for organic and inorganic analyses

Teledyne Isotopes, Inc. for radioactive analytes on samples collected in 1983 except for well MPT 1 on 9-22-83 which was done by Controls for Environmental Pollution, Inc.

Controls for Environmental Pollution, Inc. for radioactive analytes on samples collected in 1984.

The following is a list of the analytes not reported. They are arranged according to the reason for not reporting them. 
- Secondary drinking water standard of little value in this study.

Color

Corrosivity

Fecal Coloform

Odor

Turbidity

- Lab blank and or field blank at comparable concentration to

s amples.

Benzene

Bis (2-ethylhexyl) phthalate

Chloroform

Diethyl Phthalate

Di-n-Butyl Phthalate

Ethylbenzene

Methylene Chloride

Nitrobenzene

Toluene

Trichlorofluoromethane

- Not detected by the method used

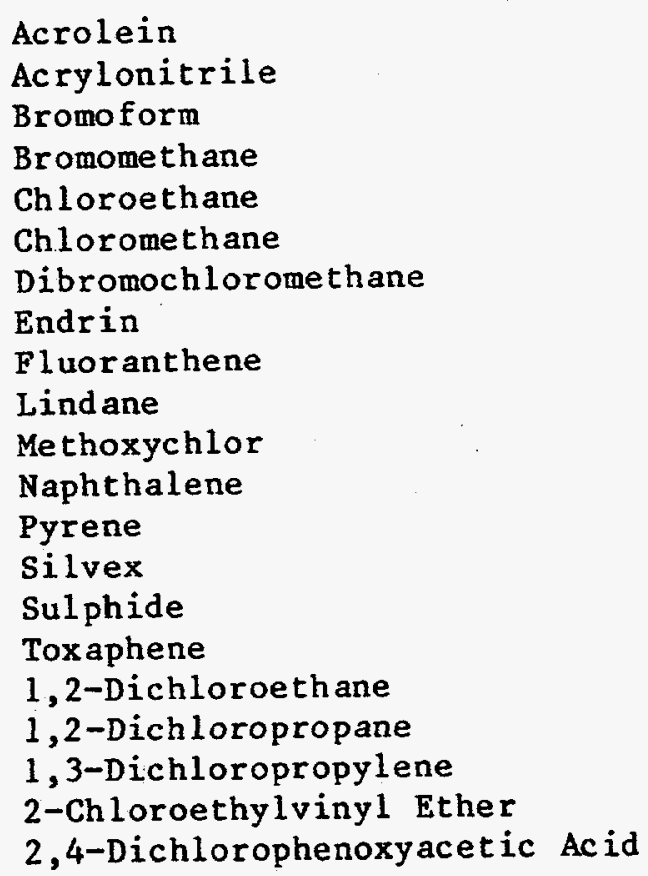

- Not of significance

Silicon 


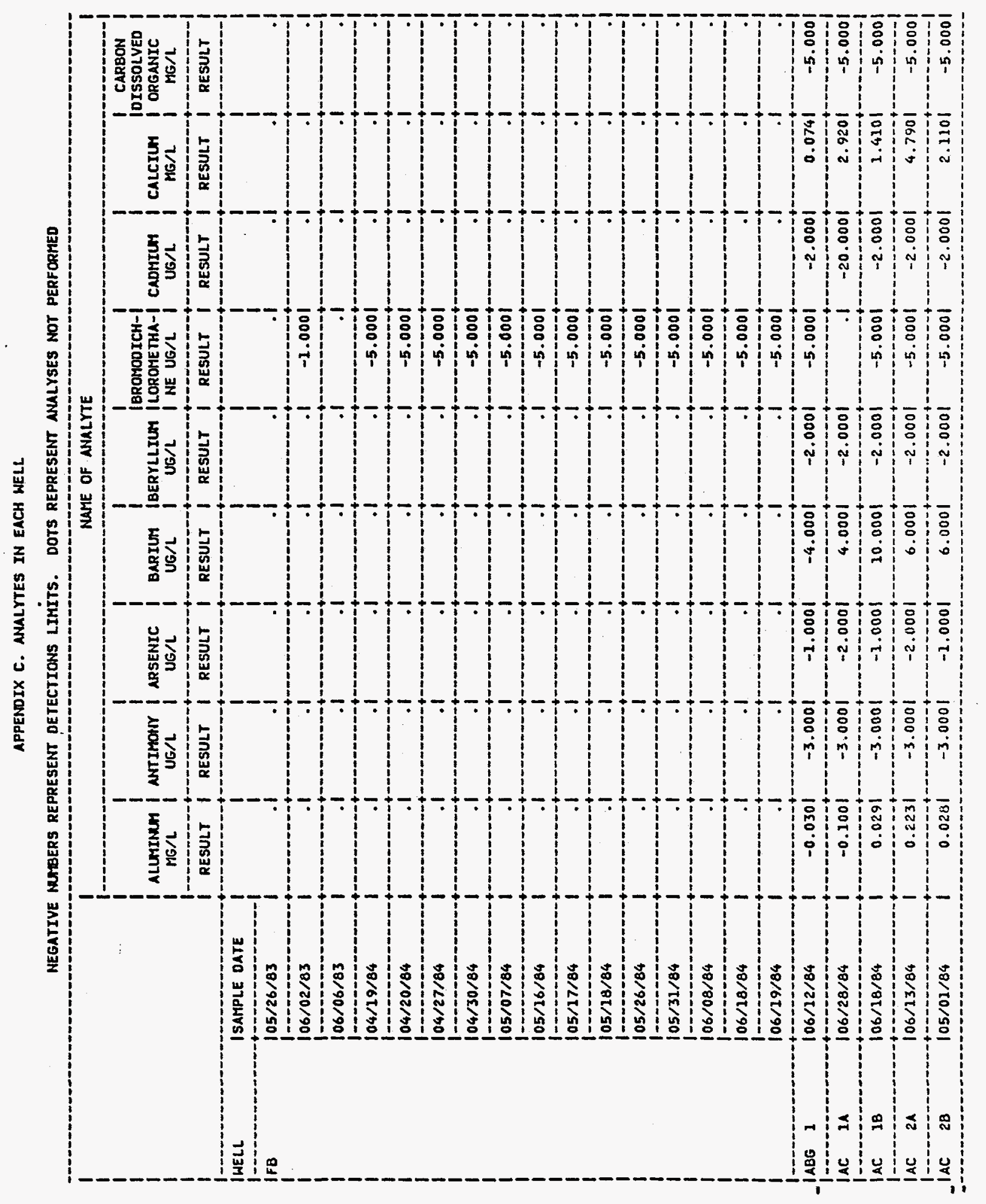

喜 
APPENDIX C. AMLLYTES IN EACH WELL

NEGATIVE MURERS REPRESENT OETECTIONS LIMITS. DOTS REPRESENT AMULYSES NOT PERFORMED

\begin{tabular}{|c|c|c|c|c|c|c|c|c|c|c|}
\hline ! & & $\sum_{\substack{\mathrm{MG} / \mathrm{L} \\
\text { Aluminm }}}$ & $\begin{array}{c}\text { ANTIMONY } \\
\text { UG/L }\end{array}$ & $\begin{array}{c}\text { ARSENIC } \\
\text { UG } / L\end{array}$ & $\begin{array}{c}\text { BARIUYI } \\
\text { UG/L }\end{array}$ & $\begin{array}{l}\text { YE OF ANALYY } \\
\text { BERYLIUM } \\
\text { UG/L }\end{array}$ & $\begin{array}{l}\text { ITE } \\
\text { IBROMODICH-I } \\
\text { ILOROME THA-I } \\
\text { I NE UG/L }\end{array}$ & $\underset{U G / L}{\text { CADMIUH }}$ & $\underset{\text { MG/L }}{\text { CALCIUM }}$ & $\begin{array}{c}\text { CARBON } \\
\text { IOISSOLVED } \\
\text { ORGANIC } \\
\text { MG/L }\end{array}$ \\
\hline & & RESULT & RESULT & RESULT & RESULT & RESULT & RESULT & RESULT & RESULT & RESULT \\
\hline IWELLL & ISAMPLE DATE & $!$ & & I & & 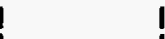 & 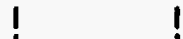 & & & \\
\hline IAC $3 A$ & $106 / 07 / 84$ & 0.2061 & -3.0001 & -1.0001 & 14.0001 & -2.0001 & -5.0001 & -2.0001 & 2.8701 & -5.0001 \\
\hline IAC $3 B$ & $106 / 07 / 84$ & 2.4701 & -3.0001 & -1.0001 & 17.0001 & -2.0001 & -5.0001 & -2.0001 & 32.7001 & $-5.000 i$ \\
\hline jAMB 2 & $106 / 11 / 84$ & 0.2741 & -3.0001 & -1.0001 & 10.0001 & -2.0001 & -5.0001 & -2.0001 & 3.6901 & -5.0001 \\
\hline$\triangle A O B \quad 1$ & $106 / 11 / 84$ & 0.2331 & -3.0001 & -1.0001 & 18.0001 & -2.0001 & -5.0001 & -2.0001 & 2.5401 & -5.0001 \\
\hline$A 0 B \quad 2$ & $106 / 11 / 84$ & 0.2401 & -3.0001 & -1.0001 & 8.0001 & -2.0001 & -5.0001 & -2.0001 & 1.2801 & -5.000 \\
\hline ASB 3 & $105 / 14 / 84$ & 0.0261 & -3.0001 & -1.0001 & 19.0001 & -2.0001 & -5.0001 & -2.0001 & $5.430 !$ & -5.0001 \\
\hline A5B 4 & $106 / 12 / 84$ & 0.2001 & -3.0001 & -1.0001 & 20.0001 & -2.0001 & -5.0001 & -2.0001 & 4.4501 & -5.0001 \\
\hline IASB 7 & $105 / 14 / 84$ & 0.0351 & -3.0001 & -1.0001 & 9.0001 & -2.0001 & -5.0001 & -2.0001 & 1.4501 & $-5.000 i$ \\
\hline ASB 8 & $105 / 30 / 84$ & 0.2841 & -3.0001 & -1.0001 & 8.0001 & -2.0001 & -5.0001 & -2.0001 & 0.7981 & -5.000 \\
\hline ¿ASB 9 & $106 / 20 / 84$ & 0.0241 & -3.0001 & -1.0001 & 23.0001 & -2.0001 & -5.0001 & -2.0001 & 2.1901 & $-5.000 i$ \\
\hline IMPT 1 & $106 / 06 / 83$ & 2.9401 & .1 & 3.0001 & -50.0001 & 6.0001 & .1 & -1.0001 & 19.1901 & 1.0001 \\
\hline 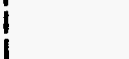 & $109 / 22 / 83$ & 4.6301 & .1 & -2.0001 & 184.0001 & 21.0001 & .1 & -2.0001 & 111.4001 & $2.000\}$ \\
\hline | & $104 / 12 / 84$ & 3.5001 & -3.0001 & -2.0001 & 150.0001 & -10.0001 & -5.0001 & -1.0001 & 21.4001 & $-5.000 i$ \\
\hline IMsB IA & $105 / 03 / 84$ & 0.0431 & -3.0001 & -1.0001 & 16.0001 & -2.0001 & -5.0001 & -2.0001 & 2.5201 & -5.0001 \\
\hline JMSB $2 A$ & $105 / 03 / 84$ & 0.2981 & -3.0001 & -1.0001 & 8.0001 & -2.0001 & -5.0001 & -2.0001 & 1.3801 & -5.0001 \\
\hline IMSB $3 A$ & $106 / 06 / 83$ & 1.8801 & .1 & -2.0001 & -50.0001 & -5.0001 & .1 & -1.0001 & 3.5101 & 5.000 \\
\hline & $105 / 03 / 84$ & 0.1041 & 25.0001 & -1.0001 & 44.0001 & -2.0001 & -5.0001 & $-2.000 i$ & 6.9301 & -5.0001 \\
\hline IMSB $4 A$ & $105 / 03 / 84$ & 0.0961 & 3.0001 & -1.0001 & 26.0001 & -2.0001 & -5.0001 & -2.0001 & 6.6701 & 6.0001 \\
\hline IMSB $5 A$ & $105 / 10 / 84$ & 0.0241 & -3.0001 & -1.0001 & 12.0001 & -2.0001 & -5.0001 & -2.0001 & 3.6201 & -5.0001 \\
\hline IMSB $6 A$ & $105 / 10 / 84$ & 0.0341 & -3.0001 & -1.0001 & 6.0001 & -2.0001 & -5.0001 & -2.0001 & 0.8521 & -5.0001 \\
\hline IMSB 7A & $105 / 10 / 84$ & 0.0381 & -3.0001 & -1.0001 & 11.0001 & -2.0001 & -5.0001 & -2.0001 & 1.2301 & -5.0001 \\
\hline
\end{tabular}

(COHTIINED) 
APPENDIX C. ANALYTES IN EACH WELL

MEGATIVE MMTBERS REPRESENT DETECTIONS LIMITS. DOTS REPRESENT ANALYSES NOT PERFORMED

\begin{tabular}{|c|c|c|c|c|c|c|c|c|c|c|}
\hline i & & $\mid$ & $\underset{U G / L}{\operatorname{ANTIMONY}}$ & $\underset{\text { UG L }}{\operatorname{ARSEHIC}}$ & $\begin{array}{c}\text { MARIUM } \\
\text { UG/L }\end{array}$ & $\begin{array}{l}\text { ME OF ANALYT } \\
\text { IBERYLLIUA } \\
\text { UG/L }\end{array}$ & $\begin{array}{l}\text { IE } \\
\text { BOROMODICH-I } \\
\text { LORDHETHA-I } \\
\text { NE UG }\end{array}$ & $\underset{\text { UG/L }}{\text { CADMYUM }}$ & $\underset{\text { MG/L }}{\text { CALCTUNA }}$ & $\begin{array}{c}\text { CARBON } \\
\text { IDISSOLVED } \\
\text { ORGAHIIC } \\
\text { MG/L }\end{array}$ \\
\hline & & RESULT I & RESULT I & RESULT & RESULT & I RESULT I & RESULT & ESULT & ESULT & RESULT \\
\hline WELL & ISAMPLE DATE & 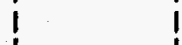 & i & & i & i & 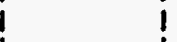 & 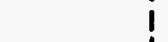 & & 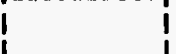 \\
\hline IMSB aA & $105 / 10 / 86$ & 0.0301 & -3.000 & -1.000 & 6.0001 & -2.0001 & -5.0001 & -2.0001 & 2.8001 & -5.000 \\
\hline MSB $9 A$ & $106 / 03 / 83$ & -0.1001 & .1 & -2.0001 & -50.0001 & -5.0001 & .1 & -1.0001 & 4.6101 & 2.00 \\
\hline & $104 / 13 / 84$ & -0.3001 & .1 & -3.0001 & -100.0001 & -10.0001 & -5.0001 & -20.0001 & 7.0001 & -5.000 \\
\hline IMSB 9B & $104 / 17 / 84$ & 0.3001 & $-3.000 i$ & -3.0001 & -100.0001 & -10.0001 & -5.0001 & -20.0001 & 10.4001 & 8.0001 \\
\hline MSB $9 \mathrm{C}$ & $106 / 02 / 83$ & -0.1001 & .1 & -2.0001 & -50.0001 & -5.0001 & .1 & -1.0001 & 2.4201 & 2.000 \\
\hline & $104 / 16 / 84$ & -0.3001 & -3.0001 & -3.0001 & -100.0001 & -10.0001 & -5.0001 & -20.0001 & 16.4001 & -5.0001 \\
\hline IMSB $10 A$ & $104 / 17 / 84$ & -0.3001 & -3.0001 & -3.0001 & 200.0001 & -10.0001 & -5.0001 & $-20.000 i$ & 0.7301 & $-5.000 i$ \\
\hline IMSB $10 B$ & $104 / 18 / 84$ & -0.3001 & -3.0001 & -3.0001 & -100.0001 & -20.0001 & -5.0001 & -20.0001 & 1.0601 & -5.000 \\
\hline IMSB $10 \mathrm{C}$ & $104 / 18 / 84$ & -0.3001 & -3.0001 & -3.0001 & -100.0001 & -10.0001 & -5.0001 & -20.0001 & 32.0001 & -5.00 \\
\hline ImSB $21 A$ & $105 / 25 / 83$ & 0.4501 & .1 & -2.0001 & -50.0001 & -5.0001 & .1 & -1.0001 & 9.0801 & $1.000 i$ \\
\hline i & $104 / 12 / 84$ & -0.3001 & -3.0001 & -2.0001 & -100.0001 & -10.0001 & -5.0001 & -1.0001 & 8.3001 & -5.0001 \\
\hline IMSB 118 & $104 / 12 / 84$ & -0.3001 & -3.0001 & $-2.000 i$ & -100.0001 & -10.0001 & -5.0001 & -1.0001 & 12.3001 & -5.00 \\
\hline IMSB $11 C$ & $104 / 12 / 84$ & 0.2371 & -3.0001 & -1.0001 & 133.0001 & -2.0001 & -5.0001 & -2.0001 & 27.1001 & -5.0001 \\
\hline IMSB 120 & $104 / 12 / 84$ & I & -3.0001 & -2.0001 & -100.0001 & -20.0001 & -5.0001 & 1.0001 & 8.2001 & $-5.000 i$ \\
\hline IMSB $11 F$ & $104 / 12 / 84$ & 1.6001 & -3.0001 & -2.0001 & -100.0001 & -10.0001 & -5.0001 & -1.0001 & 1.8201 & -5.000 \\
\hline IMSB 12A & $104 / 19 / 84$ & -0.3001 & -3.0001 & -3.0001 & 100.0001 & -10.0001 & -5.0001 & -20.0001 & 0.4701 & -5.0001 \\
\hline MSB 128 & $104 / 19 / 84$ & -0.3001 & -3.0001 & -3.0001 & -100.0001 & -10.0001 & -5.0001 & -20.0001 & 2.2401 & -5.000 \\
\hline IMSB $12 C$ & $104 / 18 / 84$ & -0.3001 & -3.0001 & -3.0001 & 400.0001 & -10.0001 & -5.0001 & -20.0001 & 2.8701 & -5.0001 \\
\hline IHSB 120 & $104 / 18 / 84$ & -0.3001 & -3.0001 & -3.0001 & 300.0001 & -10.0001 & -5.0001 & -20.0001 & 10.3001 & -5.0001 \\
\hline IHSB $12 T A$ & $105 / 25 / 84$ & I & .1 & .1 & .1 & .1 & -5.0001 & .1 & .1 & 1 \\
\hline IMSB $12 T B$ & $105 / 17 / 84$ & 0.0251 & -3.0001 & -1.0001 & 6.0001 & -2.0001 & -5.0001 & -2.0001 & 4.7001 & -5.000 \\
\hline
\end{tabular}

(COITIRUEO) 
APPENDIX C. ANALYTES IN EACH WELL

NEGATIVE MUMBERS REPRESENT DETECTIONS LIMITS. DOTS REPRESENT ANALYSES NOT PERFORMED

\begin{tabular}{|c|c|c|c|c|c|c|c|c|c|c|}
\hline 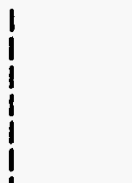 & & $\begin{array}{c}\text { ALUMINUM } \\
M G / L\end{array}$ & $\begin{array}{c}\text { ANTIMOHY } \\
\text { UG/L }\end{array}$ & $\begin{array}{c}\text { ARSENIC } \\
\text { UG/L }\end{array}$ & $\begin{array}{l}\text { BARIUH } \\
\text { UG/L }\end{array}$ & IE OF AHALLYT & $\begin{array}{l}\text { IBEOMODICH- } \\
\text { ILOROMETHA-I } \\
\text { I NE UG } / L\end{array}$ & $\underset{U G / L}{\text { CADMIUI }}$ & $\underset{M G / L}{\text { CALCIUYY }}$ & $\begin{array}{c}\text { CAREON } \\
\text { IOISSOLVEED } \\
\text { ORGANIC } \\
\text { MG/L }\end{array}$ \\
\hline & & RESULT & RESULT & RESULT & RESULT & RESULT & RESULT & RESULT & RESULT & ESULT \\
\hline IELL & ISAMPLE DATE & -1 & & & 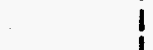 & 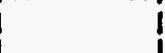 & & & & \\
\hline ASB $13 A$ & $104 / 20 / 84$ & -0.3001 & $-3.000 i$ & -3.0001 & $-100.000 i$ & -10.0001 & -5.0001 & -20.0001 & 0.8401 & -5.000 \\
\hline HSB 138 & $104 / 20 / 84$ & -0.3001 & -3.0001 & -3.0001 & -100.0001 & -10.0001 & -5.0001 & -20.0001 & 8.3301 & -5.000 \\
\hline MSB $13 C$ & $104 / 20 / 84$ & -0.3001 & -3.0001 & -3.0001 & -100.0001 & -10.0001 & -5.0001 & -20.0001 & 2.2301 & -5.000 \\
\hline 1SB $14 A$ & $106 / 14 / 84$ & 0.3641 & -3.0001 & -1.0001 & 38.0001 & -2.0001 & -5.0001 & 2.0001 & 7.3501 & -5.000 \\
\hline IISB 24B & $104 / 13 / 84$ & -0.3001 & -3.0001 & .1 & -100.0001 & -10.0001 & -5.0001 & -1.0001 & 12.0001 & -5.000 \\
\hline ISB $14 C$ & $104 / 13 / 84$ & -0.4001 & -3.0001 & -2.0001 & -100.0001 & -10.0001 & -5.0001 & -1.0001 & 15.2001 & -5.000 \\
\hline ImSB $15 \lambda$ & $105 / 26 / 83$ & 1.1701 & .1 & -2.0001 & -50.0001 & -5.0001 & .1 & 3.0001 & 13.8001 & 2.000 \\
\hline & $104 / 16 / 84$ & -0.3001 & -3.0001 & -3.0001 & -100.1001 & -10.0001 & -5.0001 & -20.0001 & 10.0001 & -5.000 \\
\hline MSB $16 \AA$ & $105 / 25 / 83$ & 0.7301 & .1 & -2.0001 & -50.0001 & -5.0001 & 3.0001 & -1.0001 & 2.3501 & 2.000 \\
\hline & $104 / 17 / 84$ & -0.3001 & -3.0001 & -3.0001 & 700.0001 & -10.0001 & -5.0001 & -20.0001 & 5.3001 & -5.000 \\
\hline MSB 16C & $105 / 26 / 83$ & -0.1001 & .1 & -2.0001 & -50.0001 & -5.0001 & .1 & -1.0001 & 0.3401 & 2.000 \\
\hline & $104 / 17 / 84$ & -0.3001 & -3.0001 & -3.0001 & -200.0001 & -10.0001 & -5.0001 & -20.0001 & 0.4701 & -5.000 \\
\hline IIIsB 17A & $104 / 23 / 84$ & -0.3001 & -3.0001 & -3.0001 & -100.0001 & -10.0001 & -5.0001 & -20.0001 & 3.8101 & -5.000 \\
\hline $\operatorname{limsB} 178$ & $104 / 24 / 84$ & -0.3001 & -3.0001 & -3.0001 & -100.0001 & -10.0001 & -5.0001 & -20.0001 & 1.5401 & -5.000 \\
\hline MSB 1BA & $104 / 23 / 84$ & -0.3001 & -3.0001 & -3.0001 & -100.0001 & -10.0001 & -5.0001 & -20.0001 & .3001 & -5.000 \\
\hline IMSB 18B & $104 / 23 / 84$ & -0.3001 & -3.0001 & -3.0001 & -100.0001 & -10.0001 & -5.0001 & -20.0001 & 2.8101 & -5.000 \\
\hline IMsB $18 \mathrm{C}$ & $104 / 23 / 84$ & $-0.300 i$ & -3.0001 & $-3.000 i$ & -100.0001 & -10.0001 & -5.0001 & $-20.000 i$ & 0.1001 & -5.000 \\
\hline IMSB 19A & $106 / 08 / 84$ & 0.2111 & -3.0001 & -1.0001 & 8.0001 & -2.0001 & -5.0001 & -2.0001 & 2.1301 & -5.0001 \\
\hline MSB 19B & $106 / 08 / 84$ & 0.0641 & -3.0001 & -1.0001 & 6.0001 & -2.0001 & -5.0001 & -2.0001 & 0.8011 & -5.000 \\
\hline IMSB ISC & $106 / 13 / 84$ & 0.0701 & -3.0001 & -1.0001 & 5.0001 & -2.0001 & -5.0001 & 3.0001 & .1 & -5.0001 \\
\hline IMSB $20 \mathrm{~A}$ & $104 / 24 / 84$ & $-0.306 i$ & $-5 .(3) 11$ & -3.0001 & -100.0301 & -10.0001 & -5.0001 & -20.0001 & $0.4 \div 01$ & -5.0001 \\
\hline
\end{tabular}

(rOITIRUED) 
APPENDIX C. MULLYTES IN EACH WELL

NEGATIVE MUMBERS REPRESENT DETECTIONS LIMITS. DOTS REPRESENT ANALYSES NOT PERFORMED

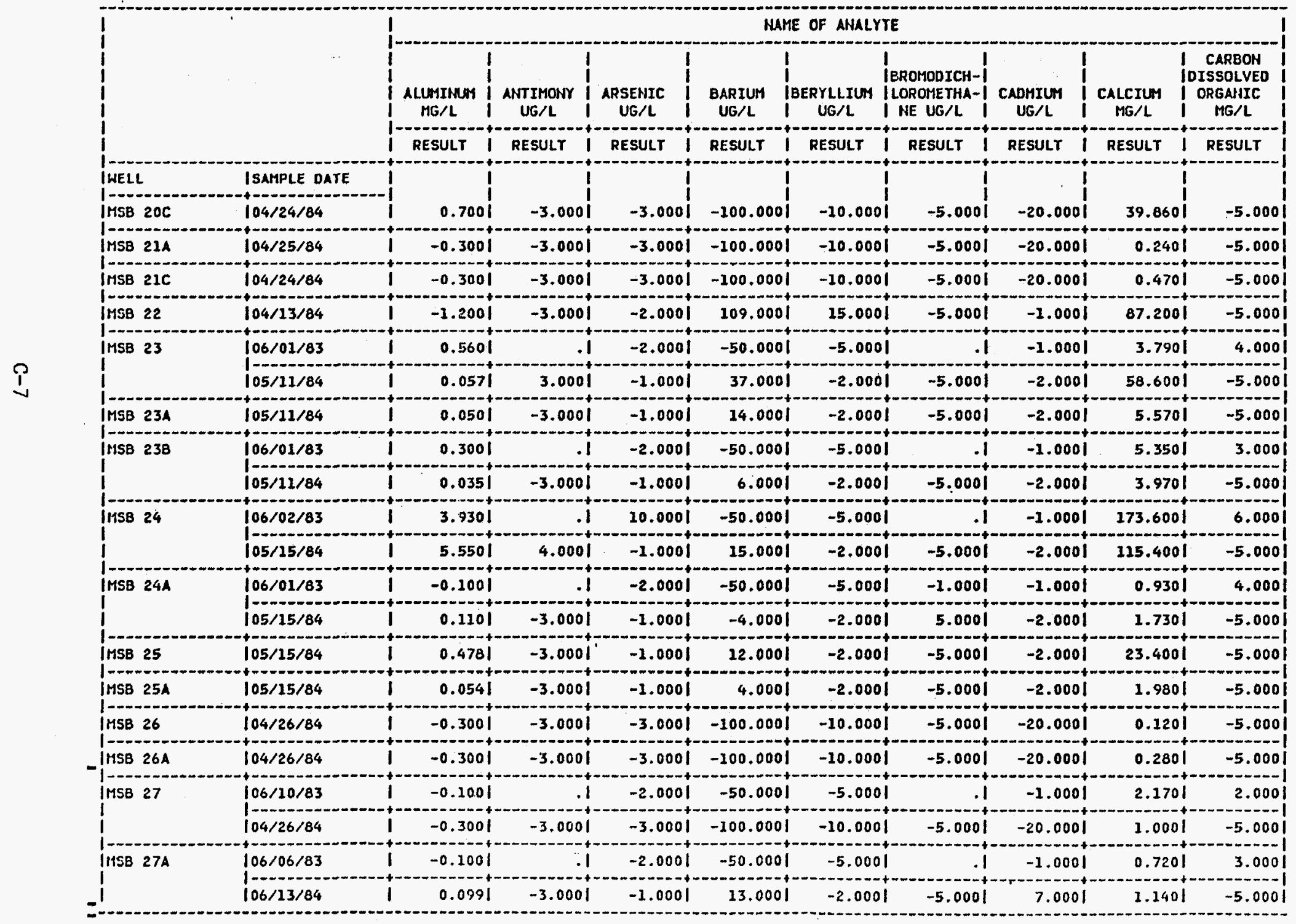

(CONTIIUUED ) 


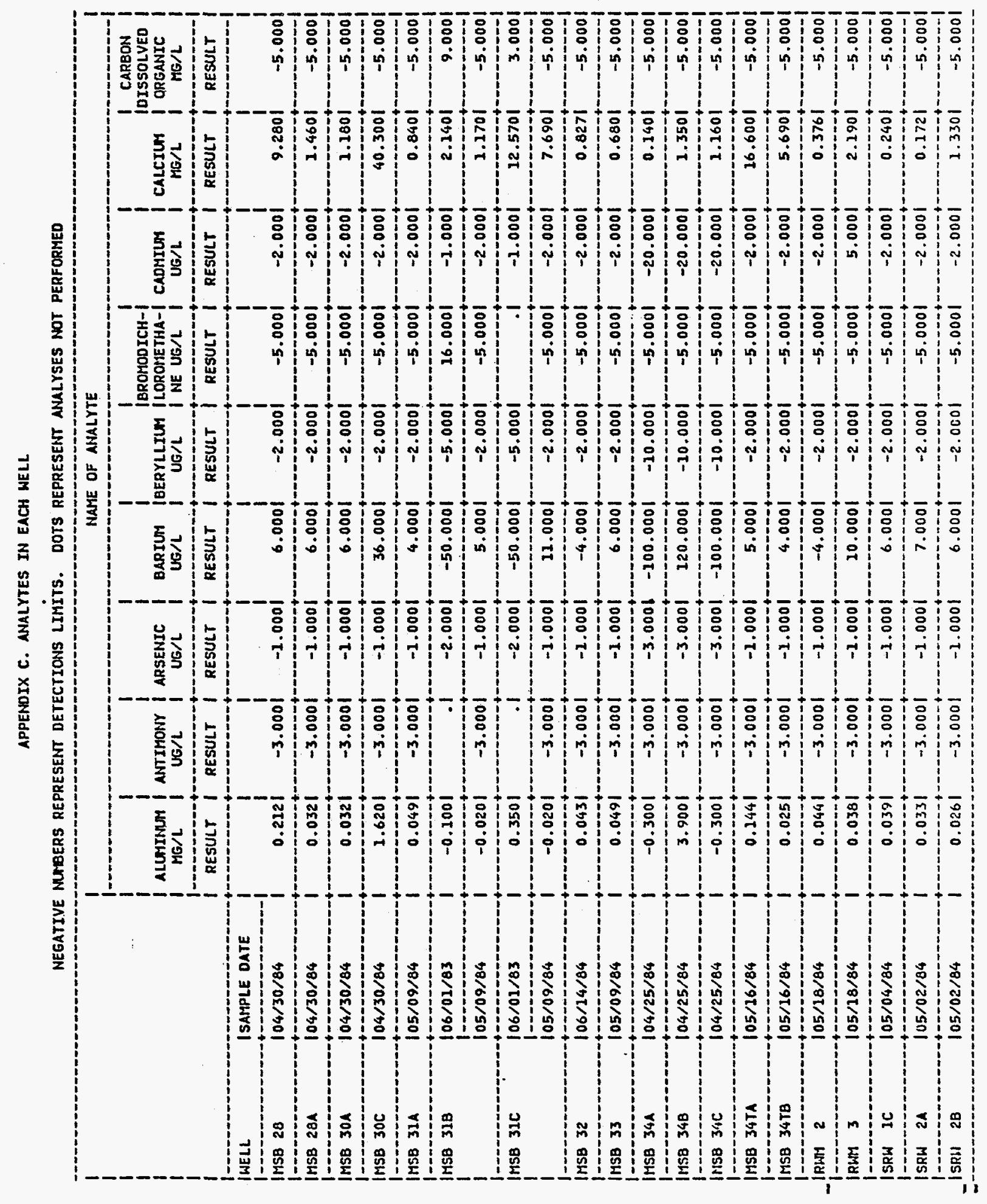


APPENDIX C. ANALITES IN EACH WELL

NEGATIVE MUMBERS REPRESENT DETECTIONS LIMITS. DOTS REPRESENT MNALYSES NOT PERFORMED

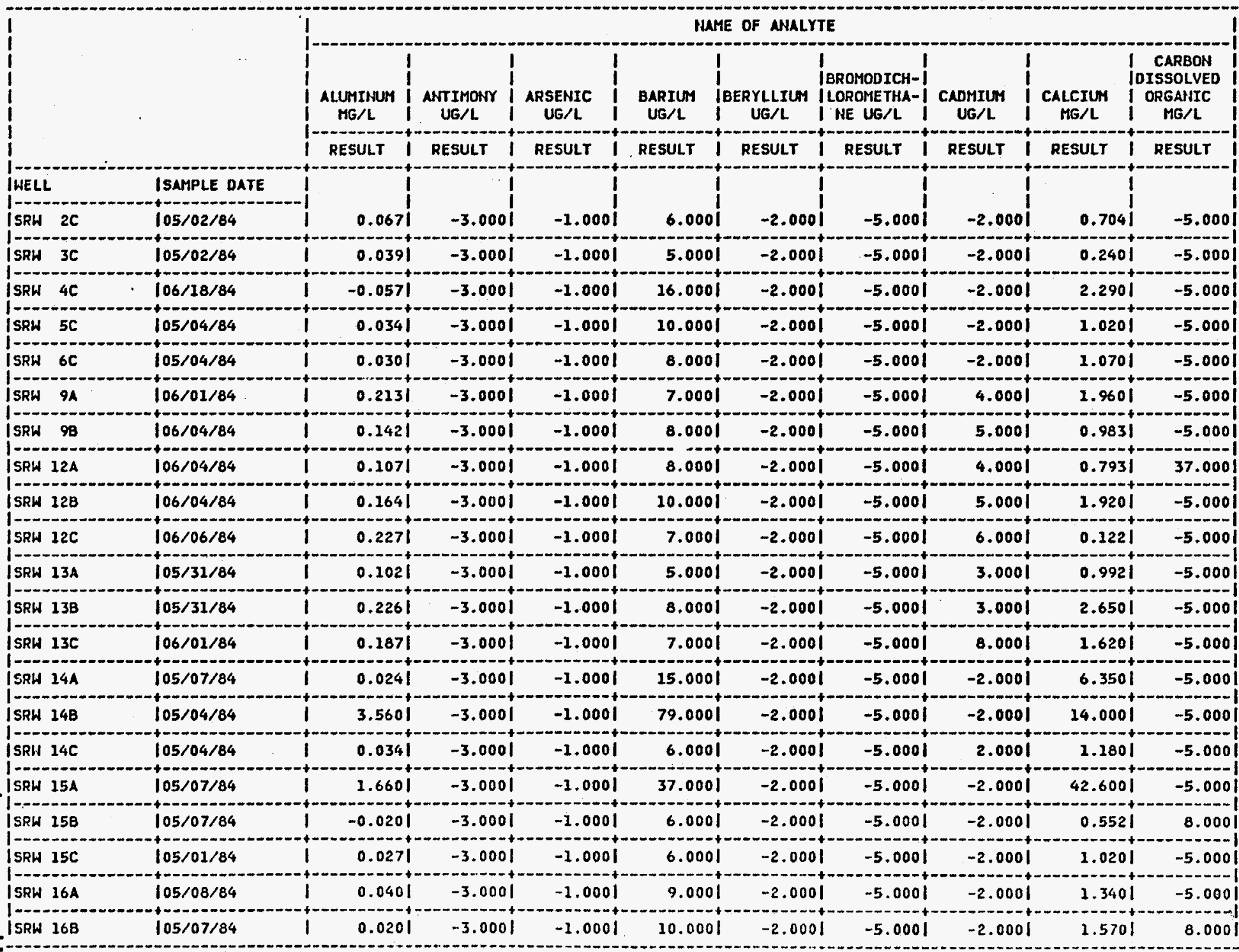




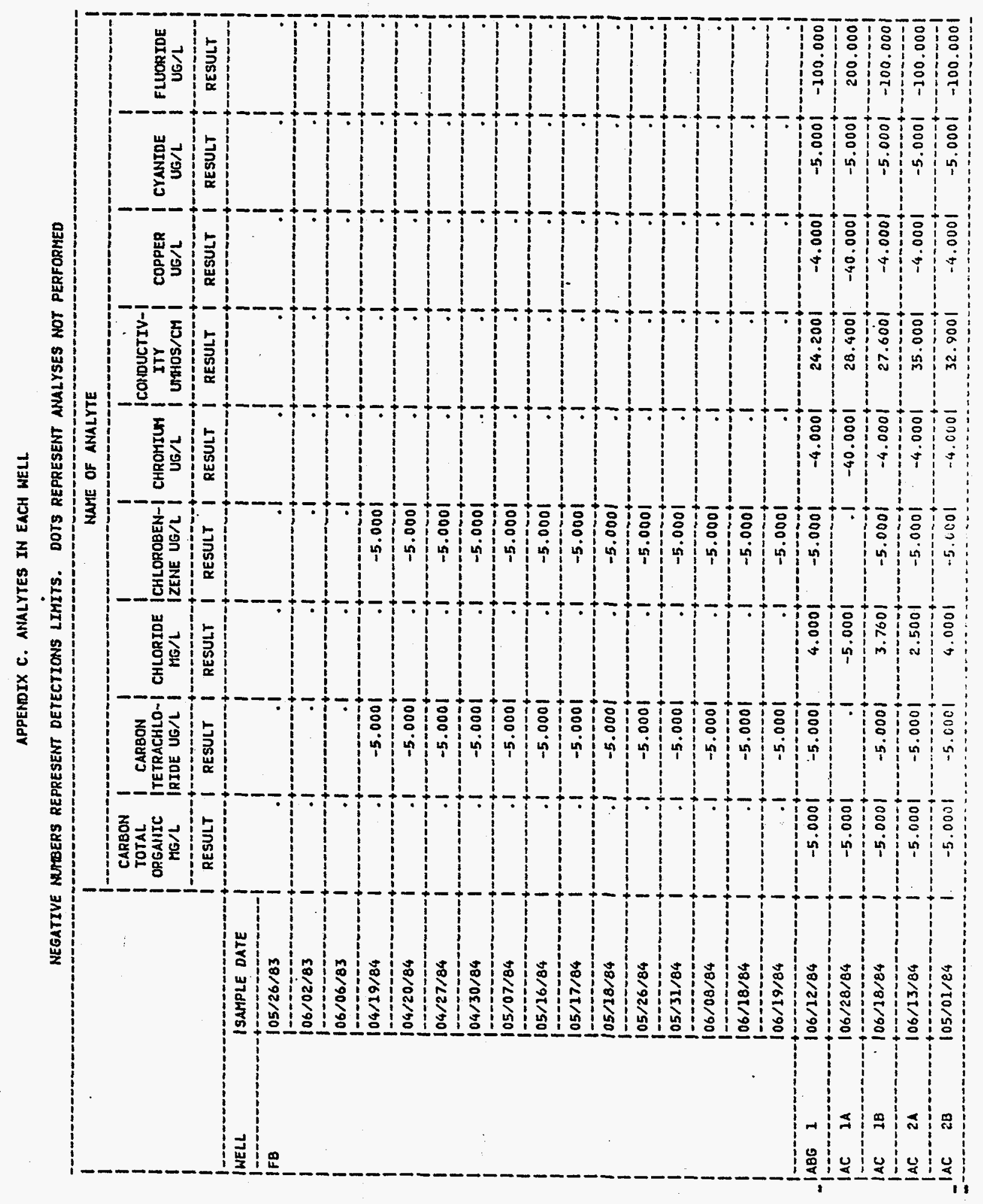


APPESDIX C. ANALYTES IN EACH WELL

NEGATIVE MUMERS REPRESENT DETECTIONS LIMITS. DOTS REPRESENT ANALYSES NOT PERFORMED

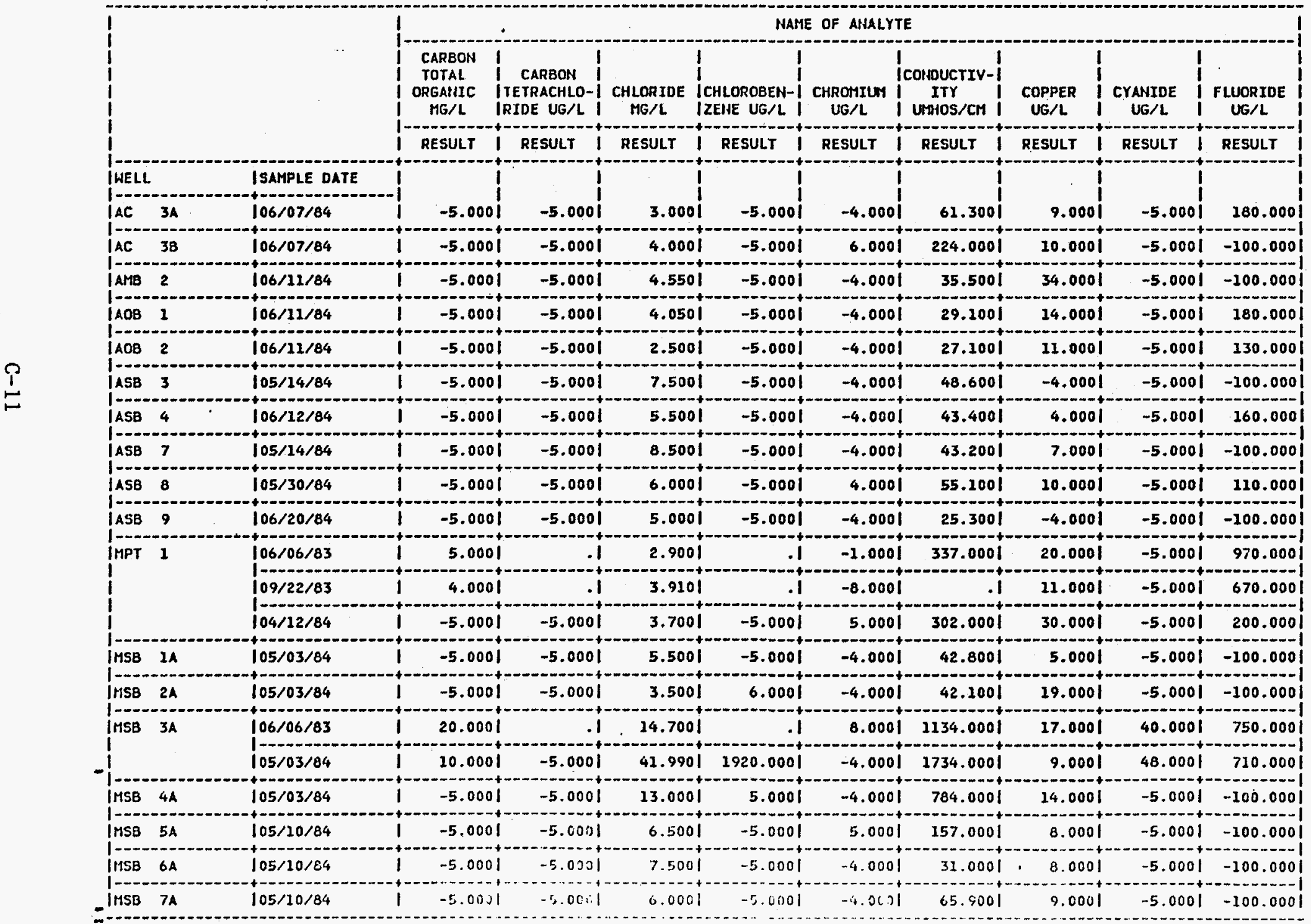

(CONTINUEO) 
APFENDIX C. AHALYTES IH EACH HELL

NEGATIVE MUHBERS REPRESENT DETECTIONS LIMITS, DOTS REPRESENT ANALYSES NOT PERFORMED

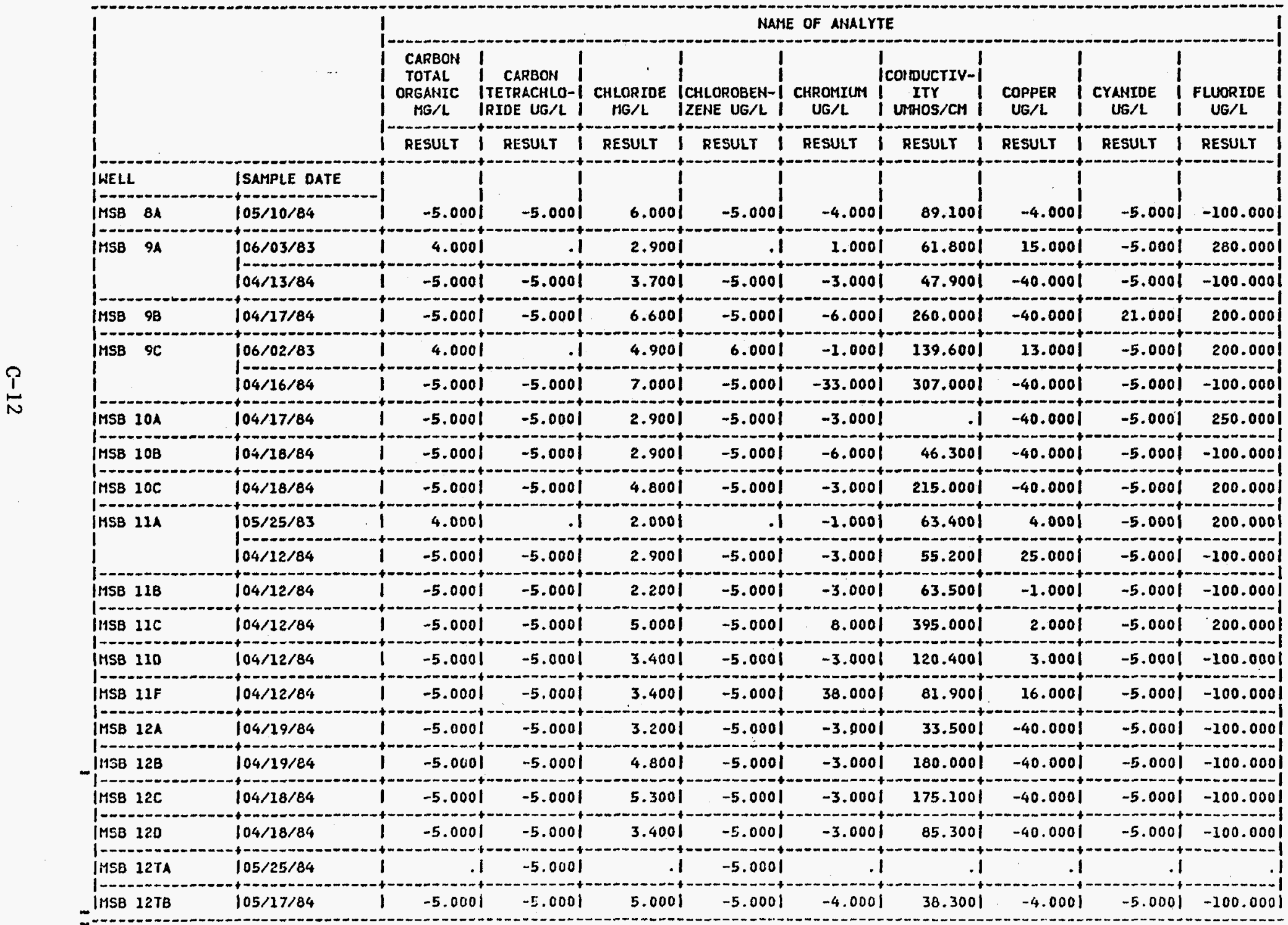

(COHIIINER) 
APPEIDIX C. ANALYTES IN EACH HELL

NEGATIVE MUMBERS REPRESENT DETECTIONS LIMITS. DOTS REPRESENT AMULYSES NOT PERFORMED

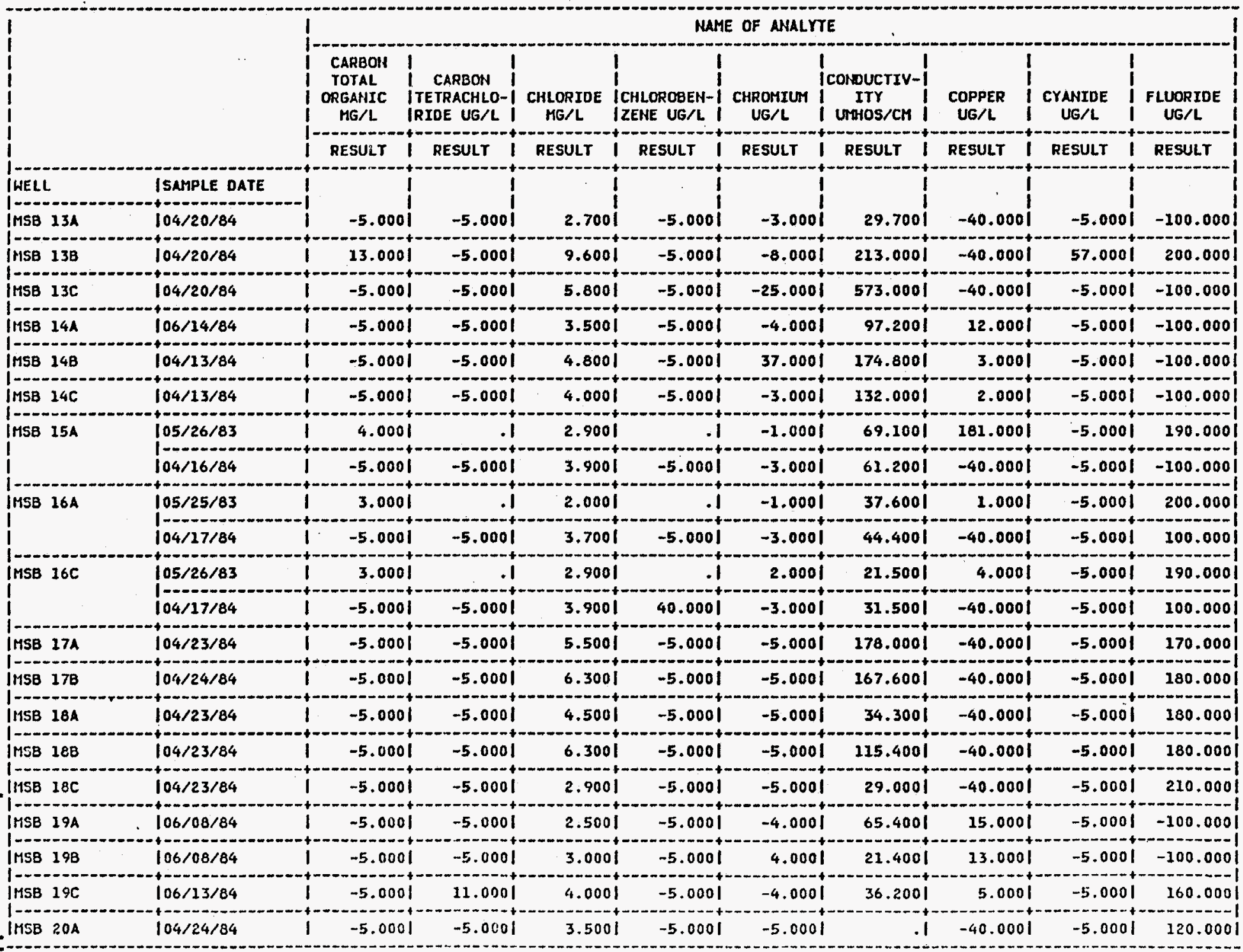

(CCHT IHNED) 
APPERDIX C. NHALYTES IN EACH WELL

MEgATIVE MUMBERS REPRESENT OETECTIONS LIMITSS. DOTS REPRESENT ANALYSES NOT PERFORMED

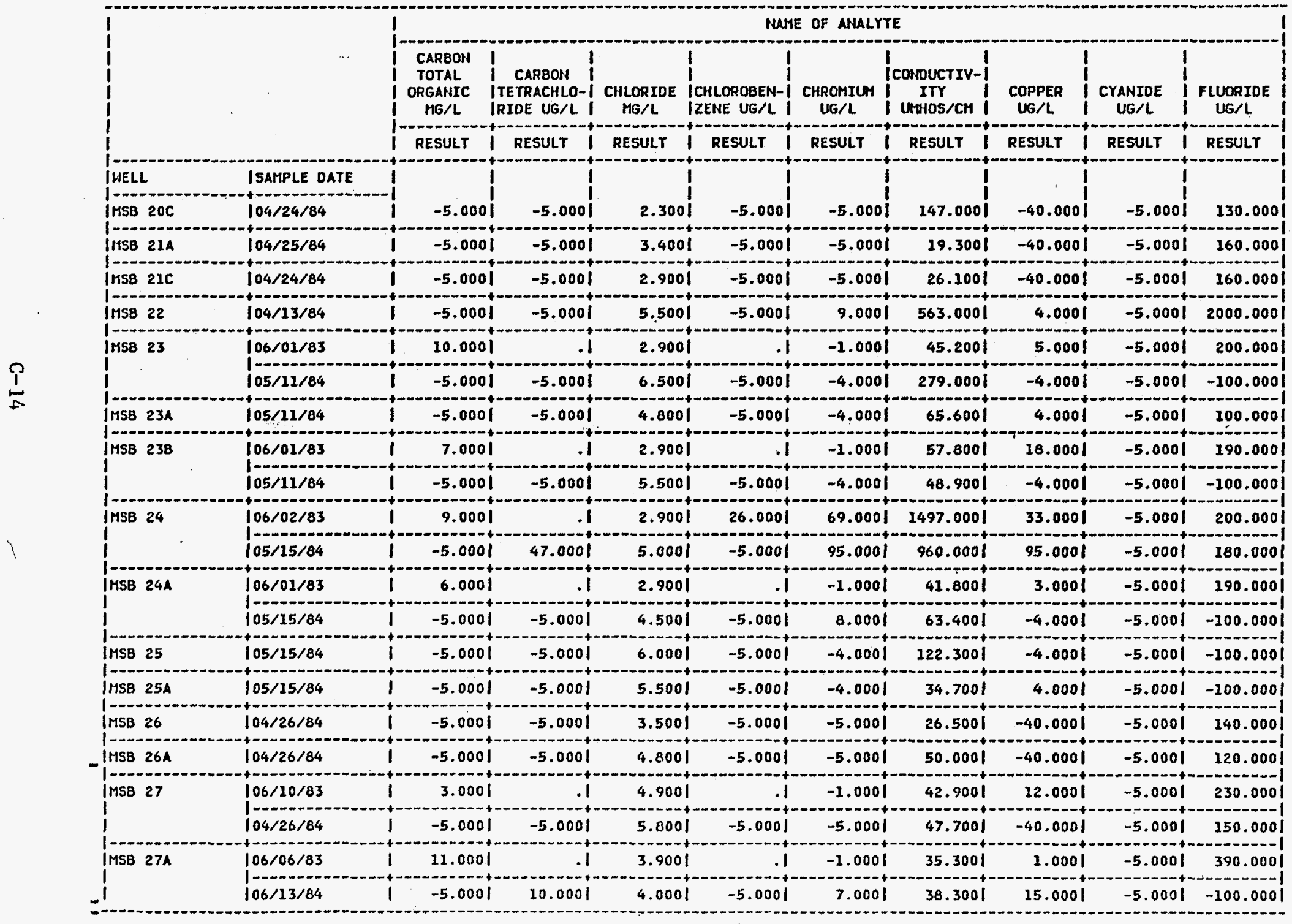


APFENDIX C. NWALYTES IN EACH WELL

NEGATIVE MUMBERS REPRESENT DETECTIOHS LIMITS. DOTS REPRESENT ANALYSES NOT PERFORMED

\begin{tabular}{|c|c|c|c|c|c|c|c|c|c|c|}
\hline $\begin{array}{l}1 \\
1 \\
1 \\
1 \\
1 \\
1\end{array}$ & ( & $\begin{array}{c}\text { CARBON } \\
\text { TOTAL } \\
\text { ORGANIC } \\
\text { MG/L }\end{array}$ & $\begin{array}{l}\text { CARBON } \\
\text { ITETRACHLO-I } \\
\text { IRIOE UG/L }\end{array}$ & CHLORIDE & $\begin{array}{l}\text { ILAME } \\
\text { ICHLORDBEN-1 } \\
\text { IZEHE UG/L I }\end{array}$ & $\begin{array}{c}\text { E OF ANALYT } \\
\text { CHROMIUH } \\
\text { UG } / L\end{array}$ & $\left\{\begin{array}{l}\text { TE } \\
\text { I cohDuctIV-I } \\
\text { ITY } \\
\text { UMHOS/Ch I }\end{array}\right.$ & $\underset{\text { UG } / L}{\text { COPPER }}$ & $\begin{array}{c}\text { CYANIDE } \\
\text { UG } / L\end{array}$ & $\begin{array}{l}\text { FLUORIDE } \\
\text { UG/L }\end{array}$ \\
\hline & & RESULT & 1 RESULT & RESULT & I RESULT & ESULT & RESULT & RESULT & RESULT & RESULT \\
\hline TWELL & ISAMPLE DATE & $i$ & i & & i & & $i$ & & i & \\
\hline $\operatorname{lnSB} 28$ & $104 / 30 / 84$ & -5.000 & -5.0001 & 3.500 & -5.0001 & -4.0001 & 77.6001 & -4.0001 & -5.0001 & -100.0001 \\
\hline MSB $28 A$ & $104 / 30 / 84$ & -5.000 & -5.0001 & 4.500 & -5.0001 & 11.0001 & 22.4001 & -4.0001 & -5.0001 & -100.000 \\
\hline IMSB 304 & $104 / 30 / 84$ & -5.000 & -5.0001 & 5.750 & -5.0001 & -4.0001 & 26.0001 & -4.0001 & -5.0001 & -100.0001 \\
\hline I H5B 30C & $104 / 30 / 84$ & -5.000 & -5.0001 & 0.9901 & -5.0001 & 6.0001 & 175.0001 & -4.0001 & -5.0001 & 260.0001 \\
\hline IMSB 31A & $105 / 09 / 84$ & -5.000 & -5.0001 & 5.500 & -5.0001 & 7.0001 & 32.2001 & -4.0001 & -5.0001 & -100.0001 \\
\hline IMSB 31B & $06 / 01 / 83$ & 4.000 & .1 & 2.900 & .1 & 3.0001 & 37.6001 & 10.0001 & -5.0001 & 200.000 \\
\hline i & $105 / 09 / 84$ & -5.000 & $-5.000 i$ & 4.500 & $-5.000 i$ & -4.0001 & 25.4001 & -4.0001 & -5.0001 & $-100.000 !$ \\
\hline IMSB 31C & $06 / 01 / 83$ & 16.000 & .1 & 4.900 &.$i$ & 5.0001 & 92.9001 & 4.0001 & -5.0001 & 280.0001 \\
\hline & $105 / 09 / 84$ & -5.000 & 8.0001 & 6.000 & -5.0001 & -4.0001 & 81.0001 & -4.0001 & -5.0001 & -100.0001 \\
\hline IMSB 32 & $106 / 14 / 84$ & -5.000 & -5.0001 & 4.000 & -5.0001 & -4.0001 & 40.8001 & 9.0001 & -5.0001 & -100.0001 \\
\hline IMSB 33 & $105 / 09 / 84$ & -5.000 & -5.0001 & 7.000 & -5.0001 & -4.0001 & 46.5001 & 4.0001 & -5.0001 & -100.0001 \\
\hline MSB $34 A$ & $104 / 25 / 84$ & -5.000 & -5.0001 & 4.300 & -5.0001 & -5.0001 & 33.7001 & -40.0001 & -5.0001 & 160.0001 \\
\hline ItisB 348 & $104 / 25 / 84$ & -5.000 & 1144.0001 & 3.400 & -5.0001 & -5.0001 & 158.0001 & -40.0001 & -5.0001 & 390.0001 \\
\hline IMSB $34 \mathrm{C}$ & $104 / 25 / 84$ & -5.000 & 84.0001 & 4.100 & -5.0001 & -5.0001 & 89.8001 & -40.0001 & -5.0001 & 210.0001 \\
\hline IMSB 34TA & $105 / 16 / 84$ & -5.000 & -5.0001 & 8.500 & -5.0001 & -4.0001 & 94.4001 & -4.0001 & $-5.000 i$ & $160.000 i$ \\
\hline IMSB $34 \mathrm{~TB}$ & $105 / 16 / 84$ & -5.0001 & $-5.000 i$ & 4.5001 & -5.0001 & -4.0001 & 65.1001 & -4.0001 & -5.0001 & -100.0001 \\
\hline 1RWM 2 & $105 / 18 / 84$ & -5.000 & -5.0001 & 4.500 & -5.0001 & -4.0001 & 28.1001 & -4.0001 & -5.0001 & 110.0001 \\
\hline RW:1 3 & $105 / 18 / 84$ & -5.000 & -5.0001 & 5.000 & -5.0001 & -4.0001 & 221.0001 & -4.0001 & -5.0001 & 200.0001 \\
\hline SRW IC & $105 / 04 / 84$ & -5.000 & -5.0001 & 4.000 & -5.0001 & -4.0001 & 23.1001 & -4.0001 & -5.0001 & -100.0001 \\
\hline ISRH $2 A$ & $105 / 02 / 84$ & -5.0001 & -5.0001 & 4.000 & -5.0001 & 7.0001 & 21.0001 & -4.0001 & -5.0001 & 110.0001 \\
\hline ISRH $2 B$ & $105 / 02 / 84$ & -5.0001 & -5.0001 & 3.0001 & -5.0001 & -4.0001 & 27.9001 & -4.0001 & -5.0001 & -100.0001 \\
\hline
\end{tabular}


APPENDIX C. ANALLTTES IN EACH HELL.

MEGATIVE MUTBERS REPRESENT DETECTIONS LIMITS. DOTS REPRESENT MULYYSES NOT PERFORMED

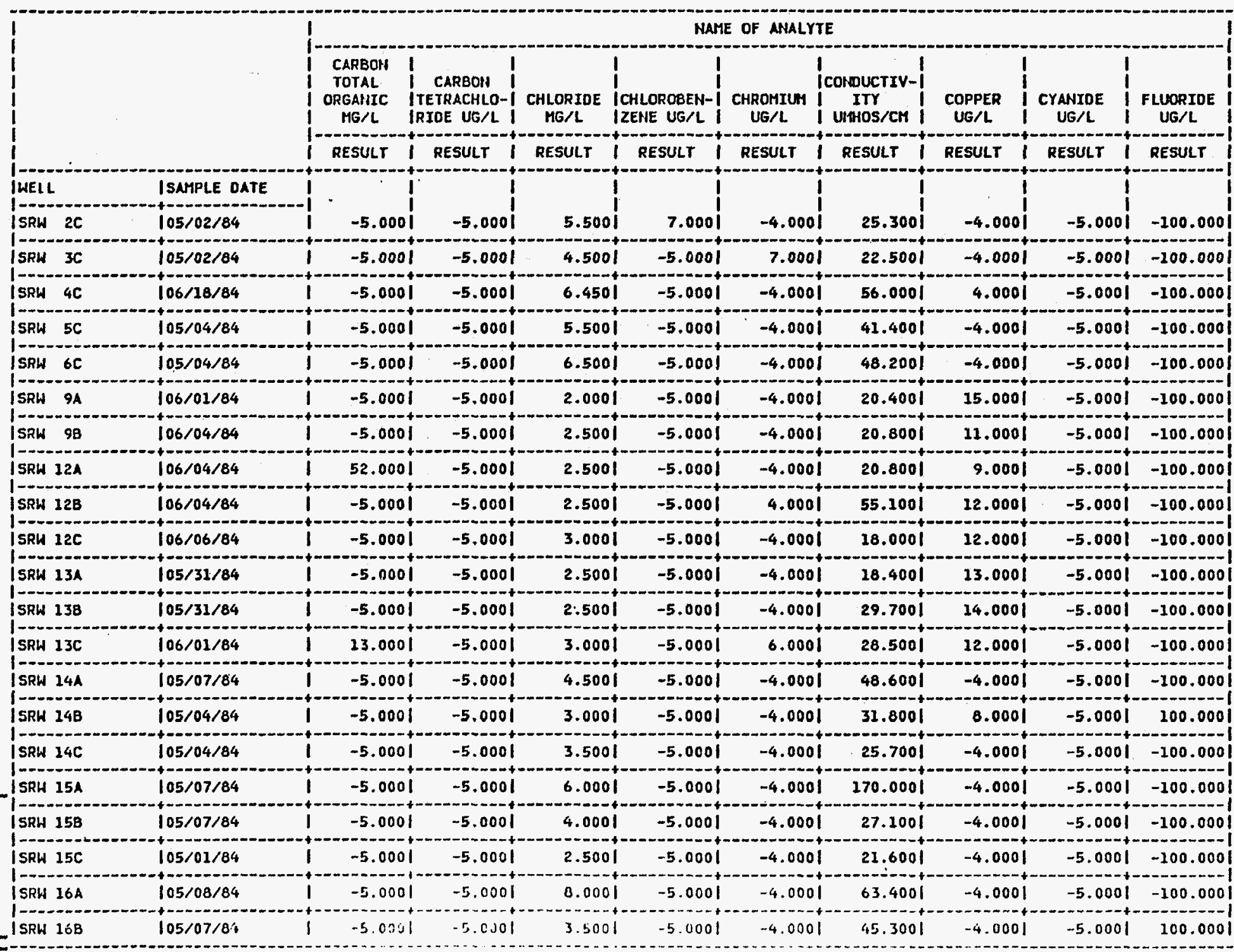


APPEROIX C. AMALYTES IN EACH WELL.

MEgATIVE MUMBERS REPRESEHT OETECTIOHS LIMITS. DOTS REPRESENT ANLLLYSES NOT PERFORMED

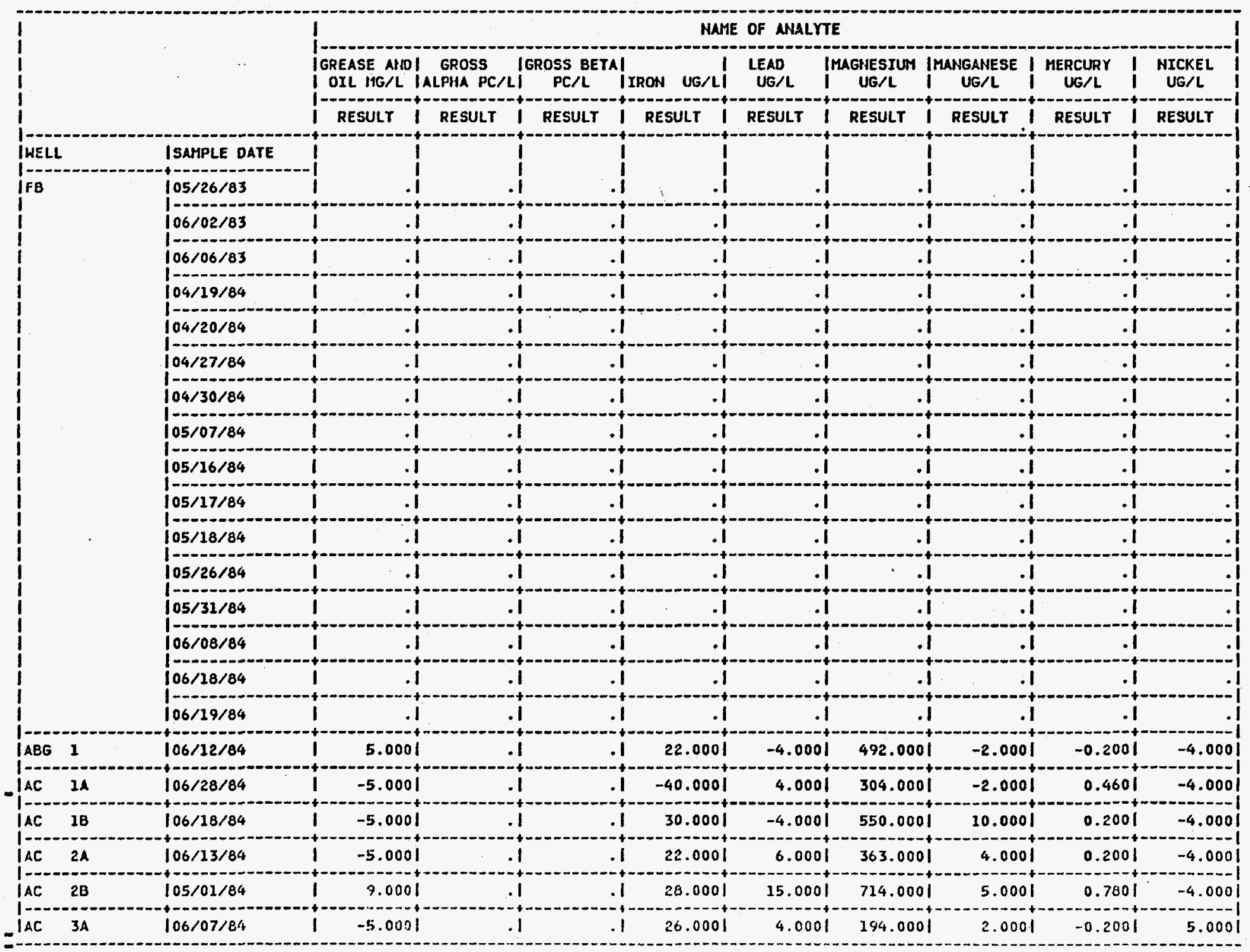


APPENOIX C. ANALYTES IN EACH WELL

MEGATIVE MURBERS REPRESENT DETECTIONS LIMITS. DOTS REPRESENT ANALYSES NOT PERFORHED

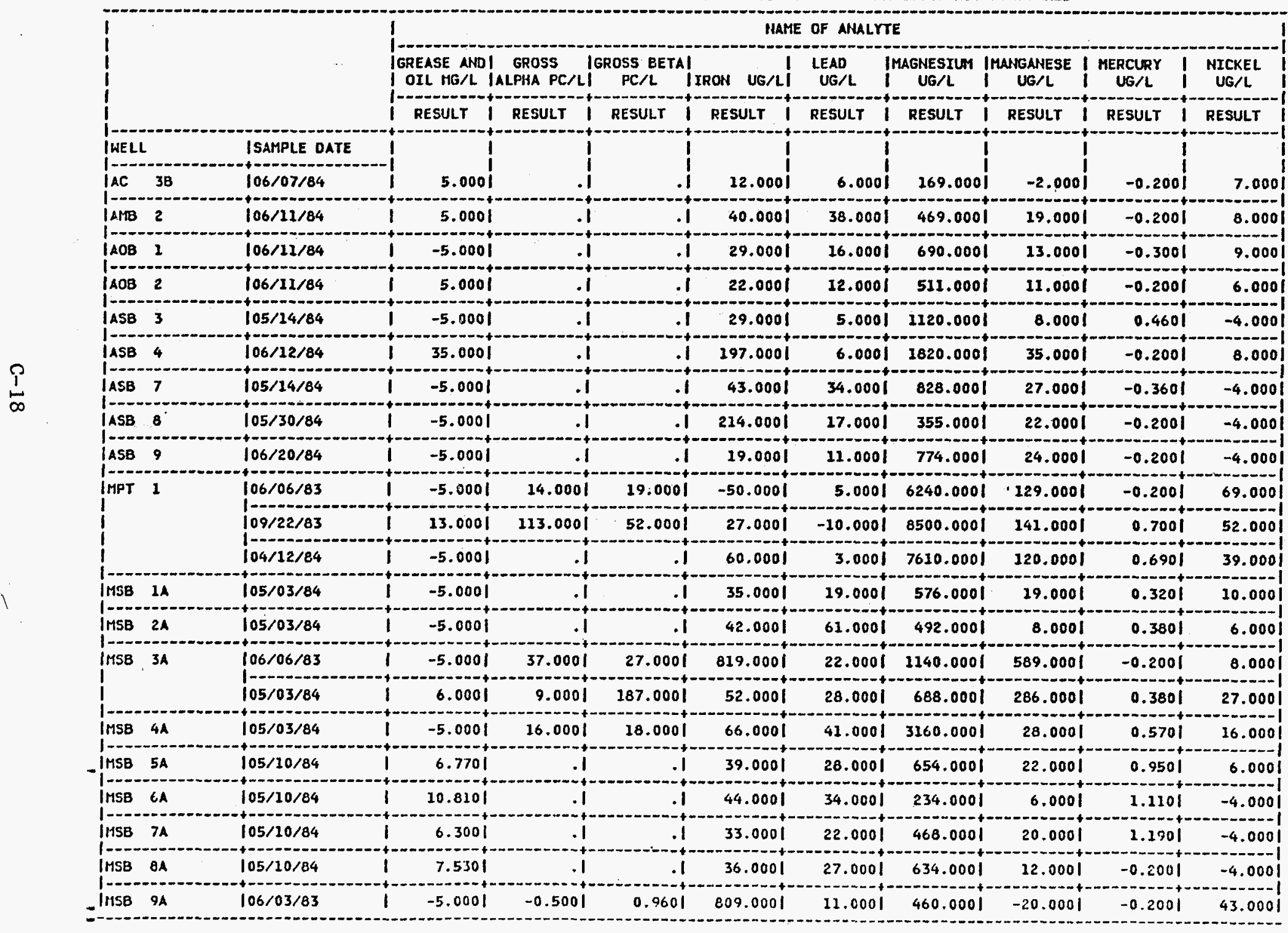

( COITIIUED) 


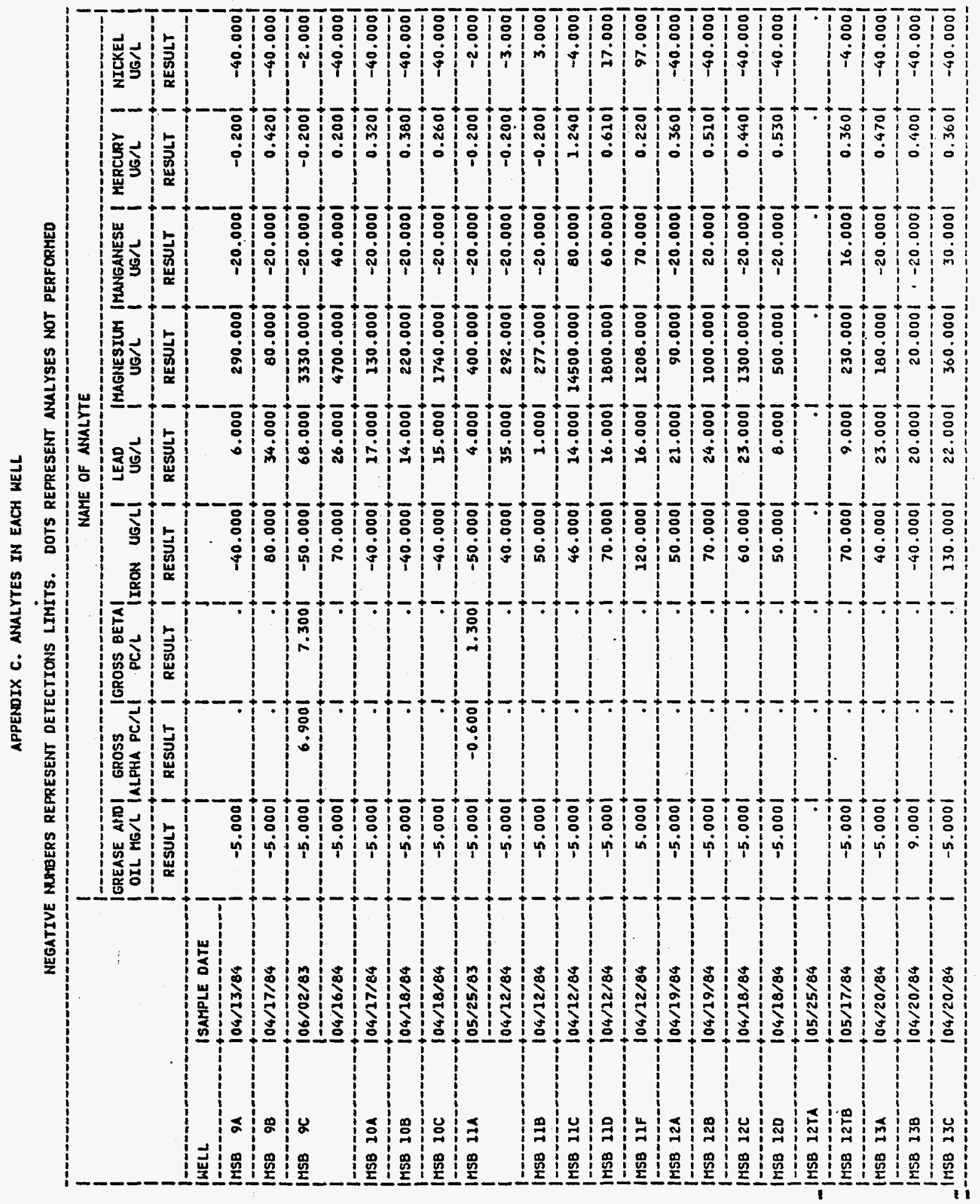




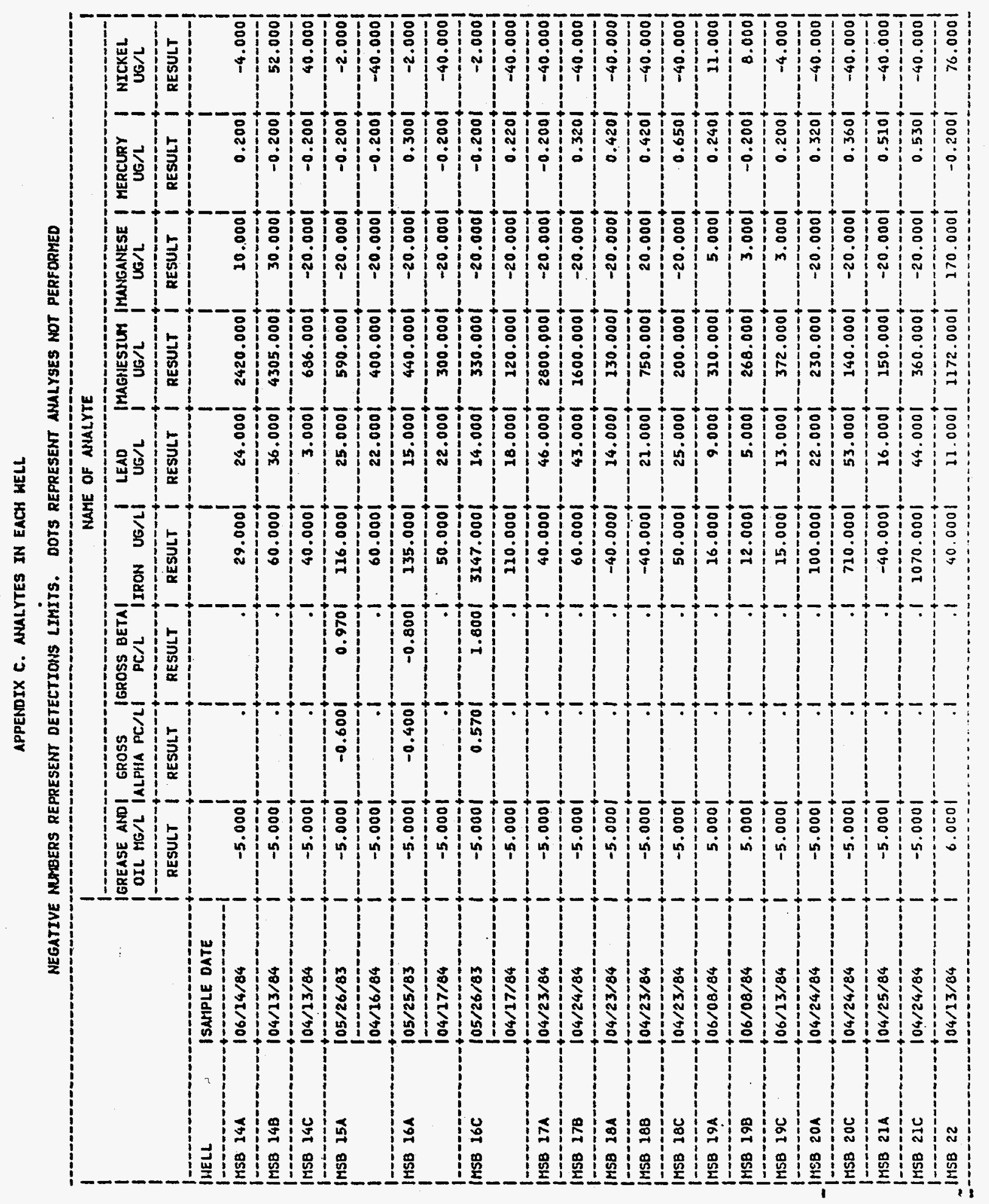




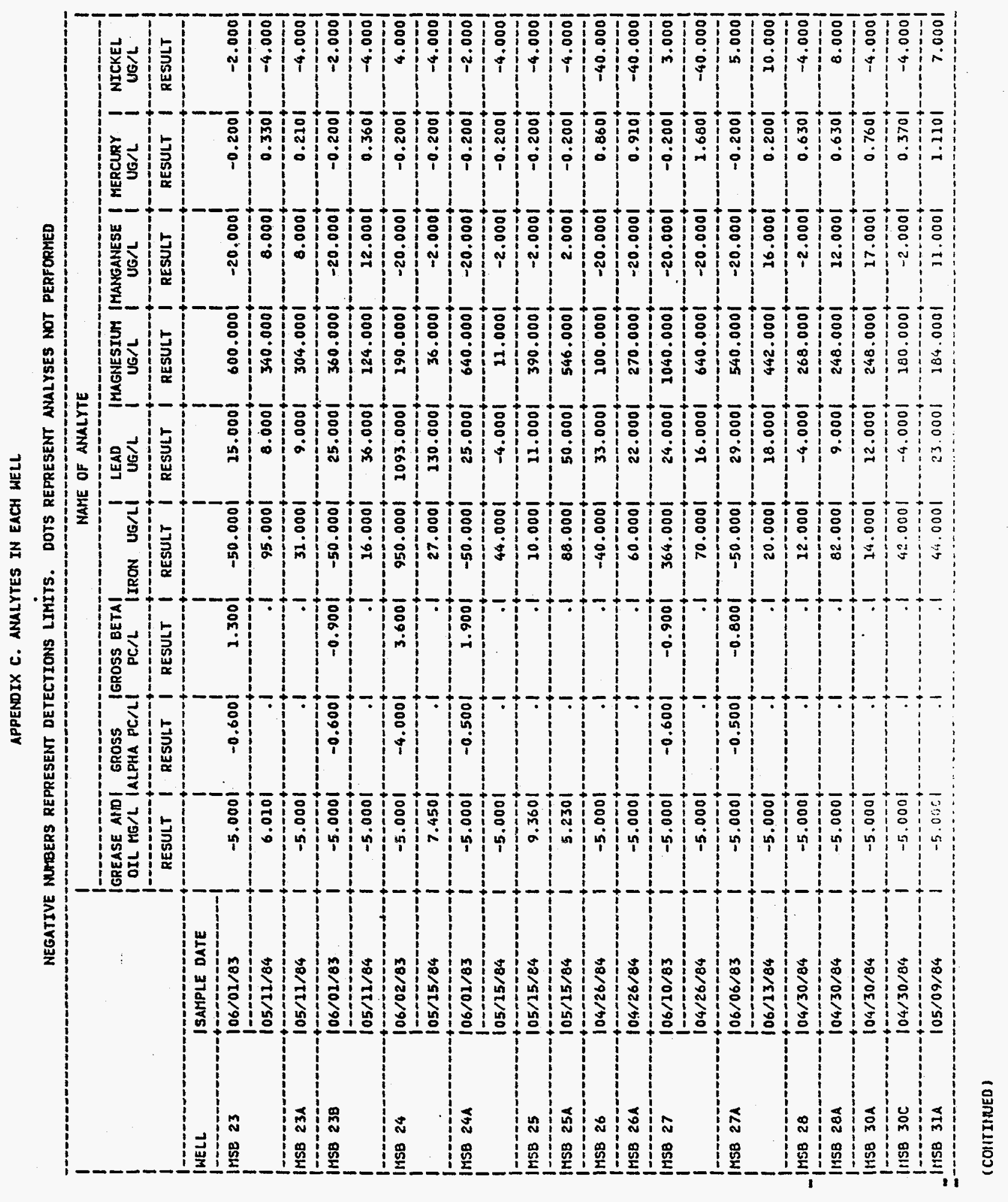


APPENDIX C. ANALYTES IN EACH WELL

NEGATIVE MUMBERS REPRESEIT DETECTIONS LIMITS. DOTS REPRESENT AMALYSES NOT PERFORMED

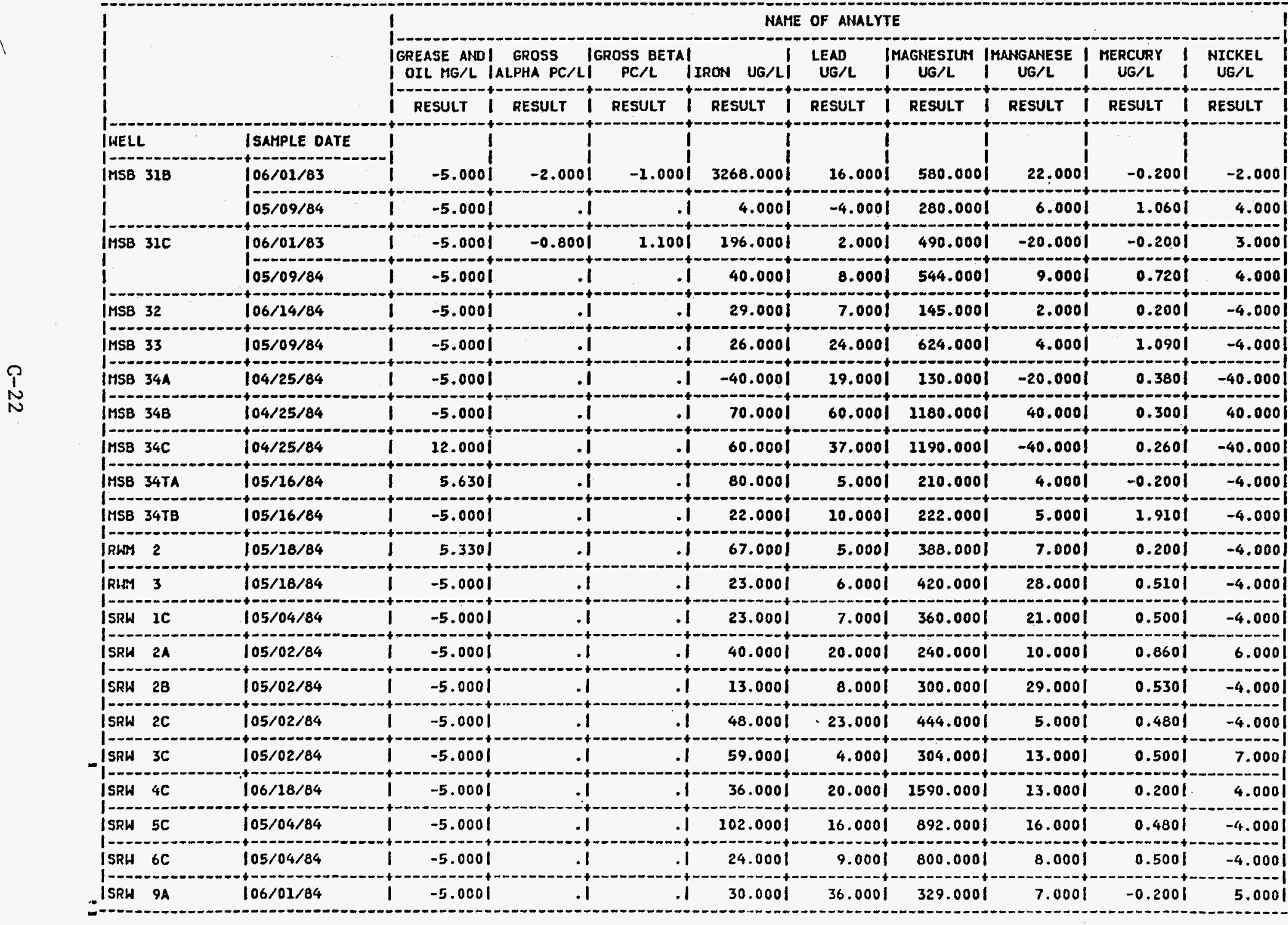

(COHTIIUED) 


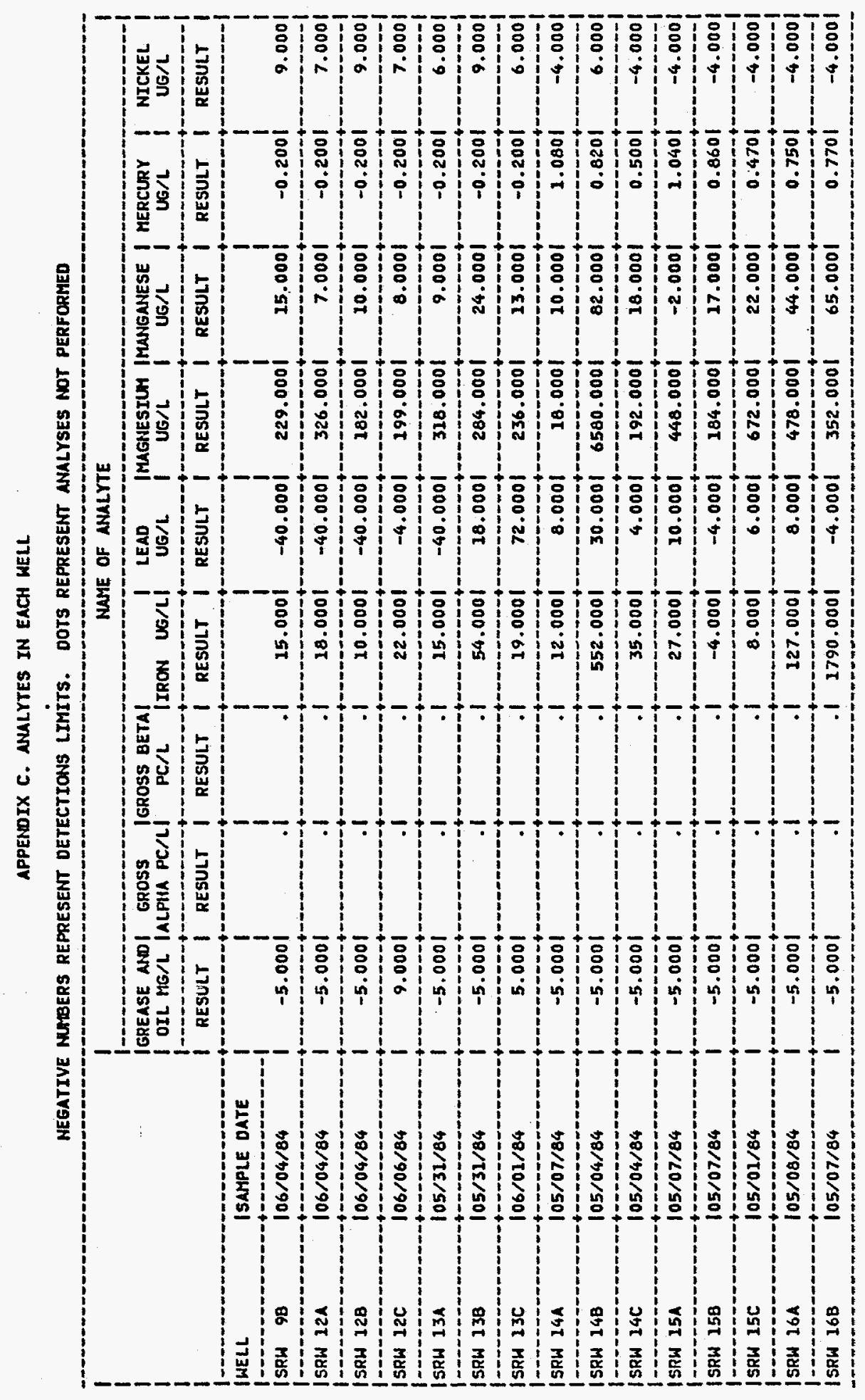




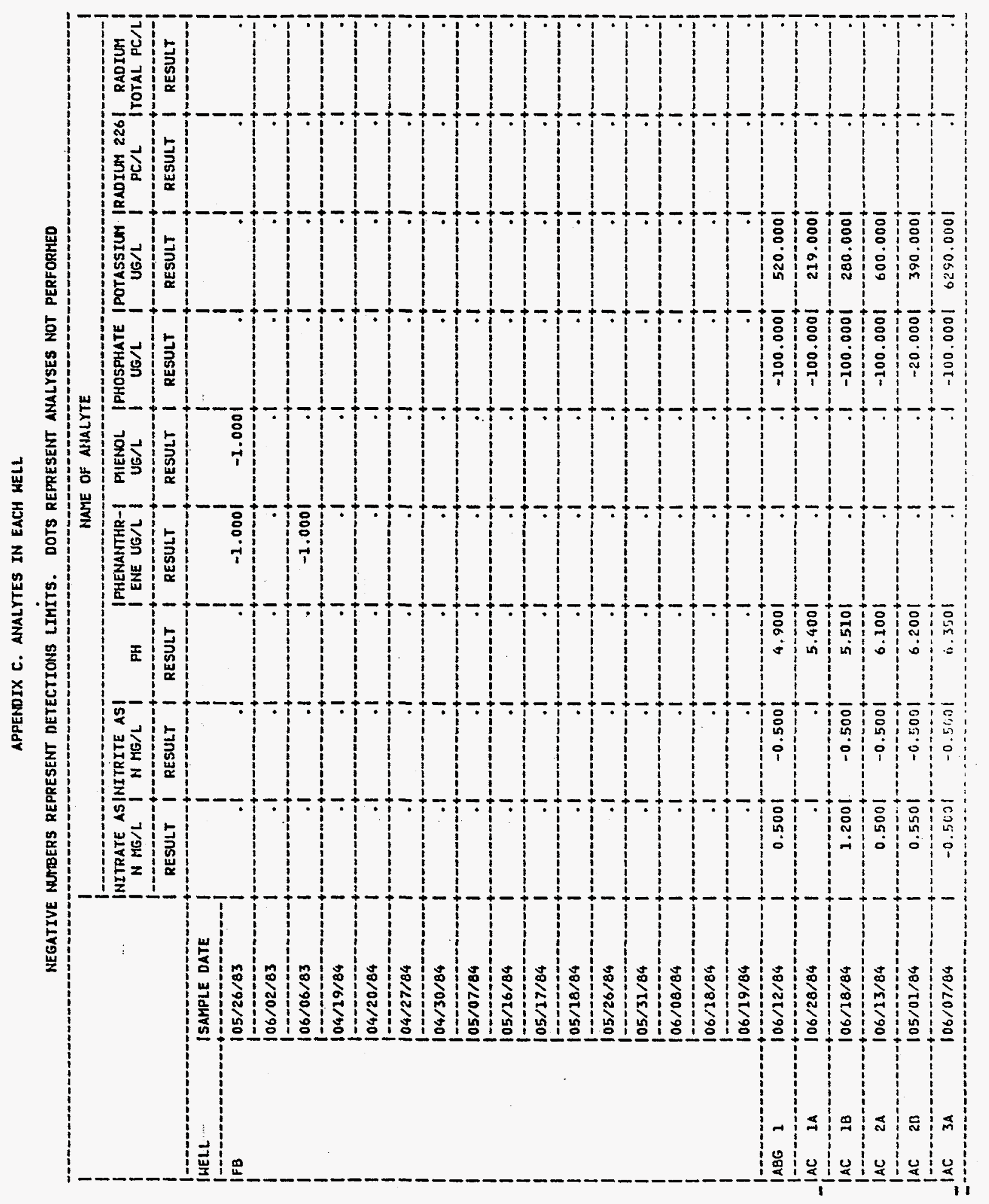

总 
APPERIOIX C. ANALYTES IN EACH WELL

NEGATIVE MURBERS REPRESENT DETECTIOHS LIMITS. DOTS REPRESENT ANALYSES NOT PERFORMED

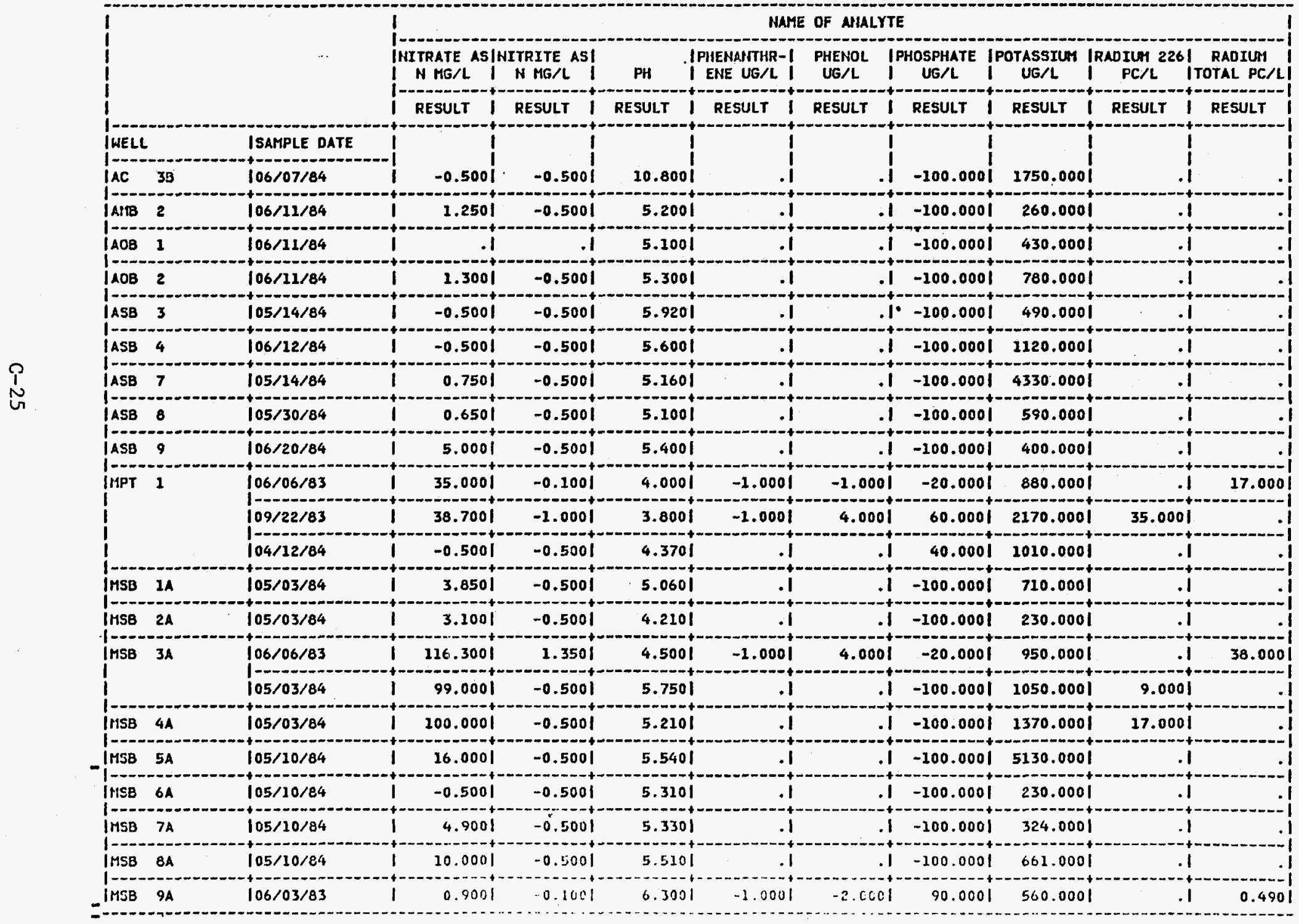

(COHITINEO) 
APPENOIX C. NHALYTES IN EACH HELL

NEGATIVE NUMBERS REPRESENT DETECTIONS LIMITS. DOTS REPRESENT ANALYSES NOT PERFORMED

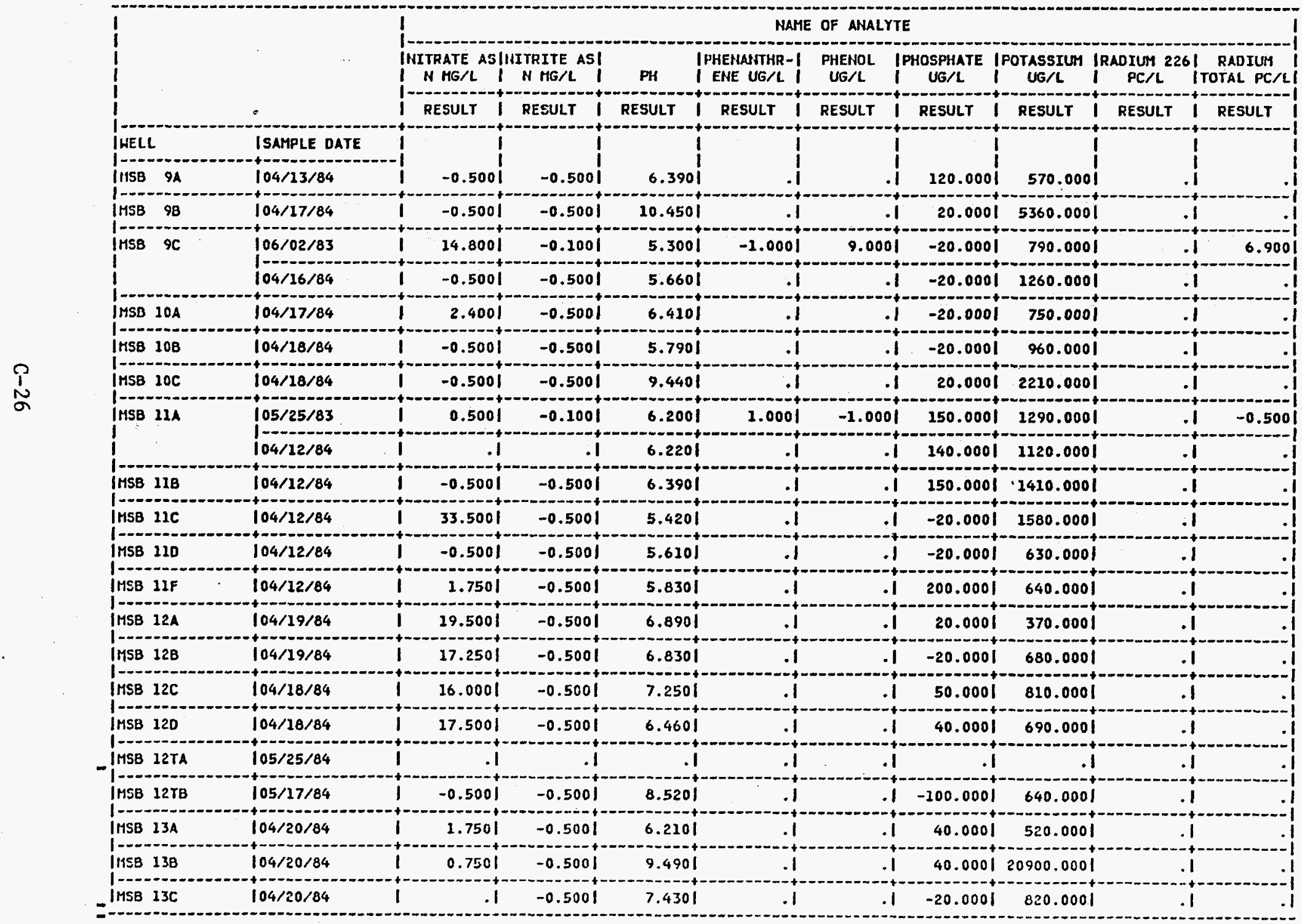

(COITIIUED) 
APPENDIX C. ANALYTES IN EACH WELL

NEGATIVE MUMBERS REPRESENT DETECTIONS LIMITS, DOTS REPRESENT ANALYSES NOT PERFORMED

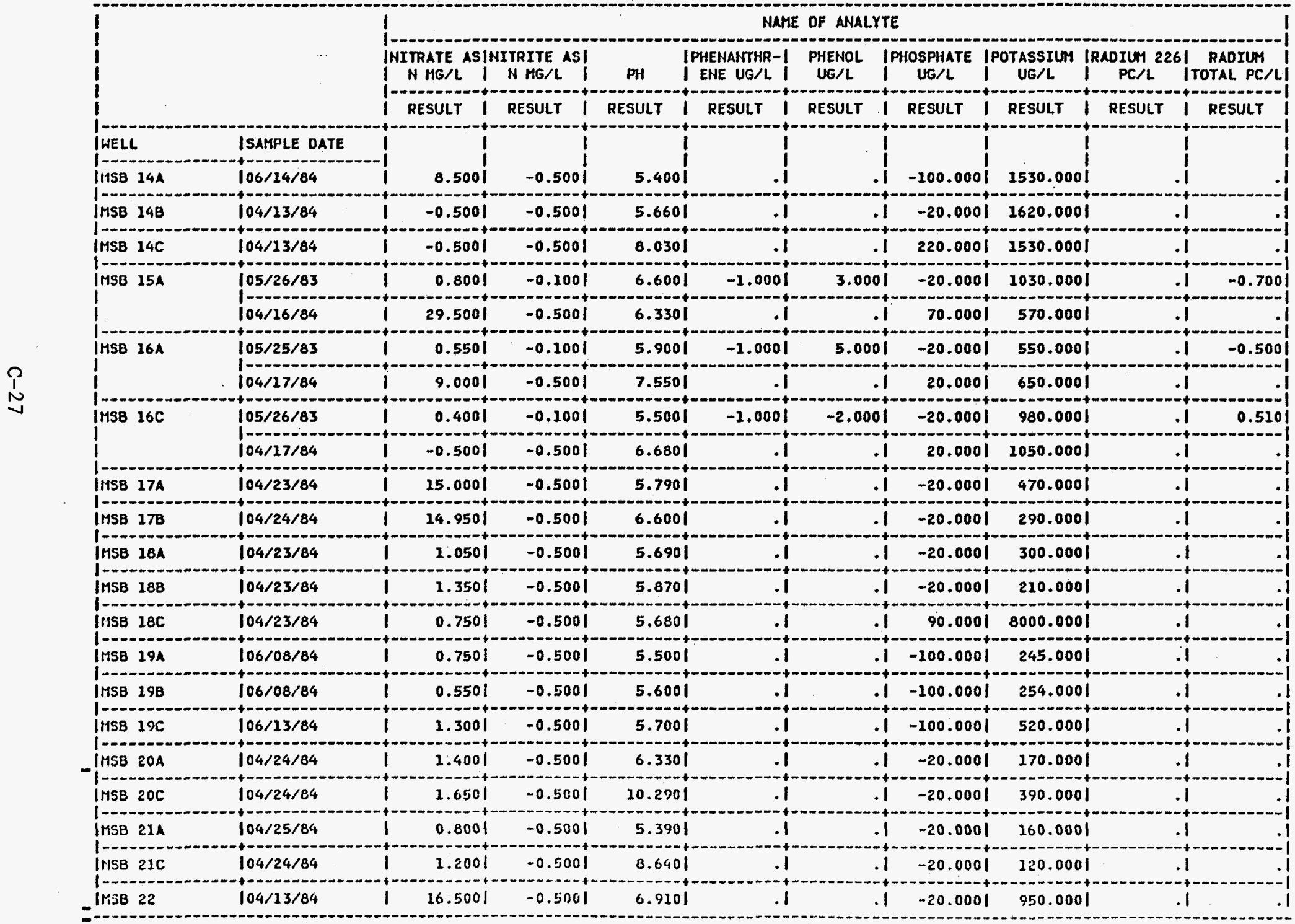

(COHTIINUED) 
APPENDIX C. ANALYTES IN EACH WELL

MEgATIVE MUREERS REPRESENT DETECTIONS LIMITS. DOTS REPRESENT ANALYSES NOT PERFORMED

\begin{tabular}{|c|c|c|c|c|c|c|c|c|c|c|}
\hline ! & & I & & & MaM & OF AHALY & YTE & & & \\
\hline i & & $\left.\right|_{\text {INITRATE ASI }}$ & $\begin{array}{c}\text { NITRITE ASI } \\
\text { N MG/L I I }\end{array}$ & PH & $\begin{array}{l}\text { PHENANTHR-I } \\
\mid \text { ENE UG/L I }\end{array}$ & $\begin{array}{c}\text { PHEHOL. } \\
\text { UG/L }\end{array}$ & $\mid \begin{array}{c}\text { PHOSPHATE } \\
\text { UG/L }\end{array}$ & $\left\{\begin{array}{c}\text { PPOTASSIUA } \\
\text { UG/L }\end{array}\right.$ & $\left.\right|_{\mathrm{PC} / \mathrm{L}} ^{\text {IRADIUIS }} 226$ & $\begin{array}{l}\text { 6ADIUM } \\
\text { ITOTAL PC/LI }\end{array}$ \\
\hline & & I RESULT I & RESULT I & RESULT & RESULT I & RESULT & RESULT & I RESULT & SULT & RESULT \\
\hline I WELL & ISAMPLE DATE & $i$ & i & & i & & i & I & i & i \\
\hline$\cdots$ & 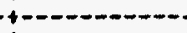 & & & & ! & & 1 & I & i & i \\
\hline |MSB 23 & $106 / 01 / 83$ & 0.8001 & -0.1001 & 5.7001 & -1.0001 & -2.000 & -20.0001 & 330.0001 & & 0.6501 \\
\hline 1 & $105 / 11 / 84$ & 11.2501 & -0.5001 & 6.5401 & .1 & & -100.000 & 012453.0001 & & .1 \\
\hline IMSB 23A & $105 / 11 / 84$ & -0.5001 & -0.5001 & 6.4401 & .1 & & -100.000 & of 2180.0001 & & .1 \\
\hline IMSB 23B & $106 / 01 / 83$ & 0.5501 & -0.1001 & 6.0001 & -1.0001 & -1.000 & 60.0001 & $' 750.000 !$ & 1 & $-0.500 i$ \\
\hline 1 & $105 / 11 / 84$ & 0.8001 & -0.5001 & 5.9601 & .1 & & -100.0001 & 290.0001 & & .1 \\
\hline IMSB 24 & $106 / 02 / 83$ & 1.8001 & -0.1001 & $11.700 \mathrm{i}$ & 1.0001 & 33.000 & 30.0001 & 013850.0001 & & -0.5001 \\
\hline 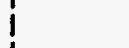 & $105 / 15 / 84$ & 1.4001 & -0.5001 & 11.6501 & .1 & & $.1-100.0001$ & 7200.0001 & & .1 \\
\hline IMSB $24 A$ & $106 / 01 / 83$ & 2.5001 & $-0.100 i$ & 5.4001 & -1.0001 & -2.000 & -20.0001 & 320.0001 & & -0.6001 \\
\hline i & $105 / 15 / 84$ & 2.7001 & $-0.500 i$ & 6.6901 &.$i$ & & .100 .0001 & 100.0001 & & .1 \\
\hline IMSB 25 & $105 / 15 / 84$ & 1.8501 & -0.5001 & 9.8801 & .1 & & 120.0001 & 70.0001 & & .1 \\
\hline IMSB $25 A$ & $105 / 25 / 84$ & 1.4501 & -0.5001 & 6.7701 & .1 & & $.1-100.0001$ & if 4250.0001 & & .1 \\
\hline IMSB 26 & $104 / 26 / 84$ & $-0.500 i$ & $-0.500 i$ & $5.490 i$ & .1 & & -20.0001 & 150.0001 & & .1 \\
\hline IMSB $26 A$ & $104 / 26 / 84$ & 2.0501 & -0.5001 & 5.5401 & .1 & & -20.0001 & 140.0001 & &.$i$ \\
\hline |HSB 27 & $106 / 10 / 83$ & 2.2501 & -0.1001 & 6.0501 & -1.0001 & $-1,000$ & -20.0001 & 220.0001 & & $0.560 i$ \\
\hline & $104 / 26 / 84$ & 2.5001 & -0.5001 & 5.6301 & .1 & & -20.0001 & 90.0001 & & .1 \\
\hline IMSB $27 A$ & $106 / 06 / 83$ & 1.1001 & $-0.100 i$ & 5.3001 & -1.0001 & -1.000 & 60.0001 & 440.0001 & & $0.340 !$ \\
\hline & $106 / 13 / 84$ & 1.2501 & -0.5001 & 5.6001 & .1 & & $.1-100.0001$ & 520.0001 & & .1 \\
\hline IMSB 26 & $104 / 30 / 84$ & -0.5001 & -0.5001 & 8.2001 & .1 & & 20.0001 & of 1050.0001 & & .1 \\
\hline |IISB 28A & $104 / 30 / 84$ & -0.5001 & -0.5001 & 5.4001 & .1 & & -20.0001 & 32000.0001 & & .1 \\
\hline IMSB $30 \mathrm{~A}$ & $104 / 30 / 84$ & -0.5001 & -0.5001 & 6.5001 & .1 & & -20.0001 & 250.0001 & & .1 \\
\hline IMSB 30C & $104 / 30 / 84$ & -0.5001 & -0.5001 & 10.5001 & .1 & & -20.0001 & i 3300.0001 & i & .1 \\
\hline IMSB $31 \mathrm{~A}$ & $105 / 09 / 84$ & -0.5001 & -0.5001 & 6.0901 & .1 & & $.1-100.000$ & 280.0001 & & .1 \\
\hline
\end{tabular}

( INITITINED ) 
APPENDIX C. AMALYTES IN EACH WELL

NEGATIVE MUABERS REPRESENT DETECTIONS LIMITS. DOTS REPRESENT ANALYSES NOT PERFORMED

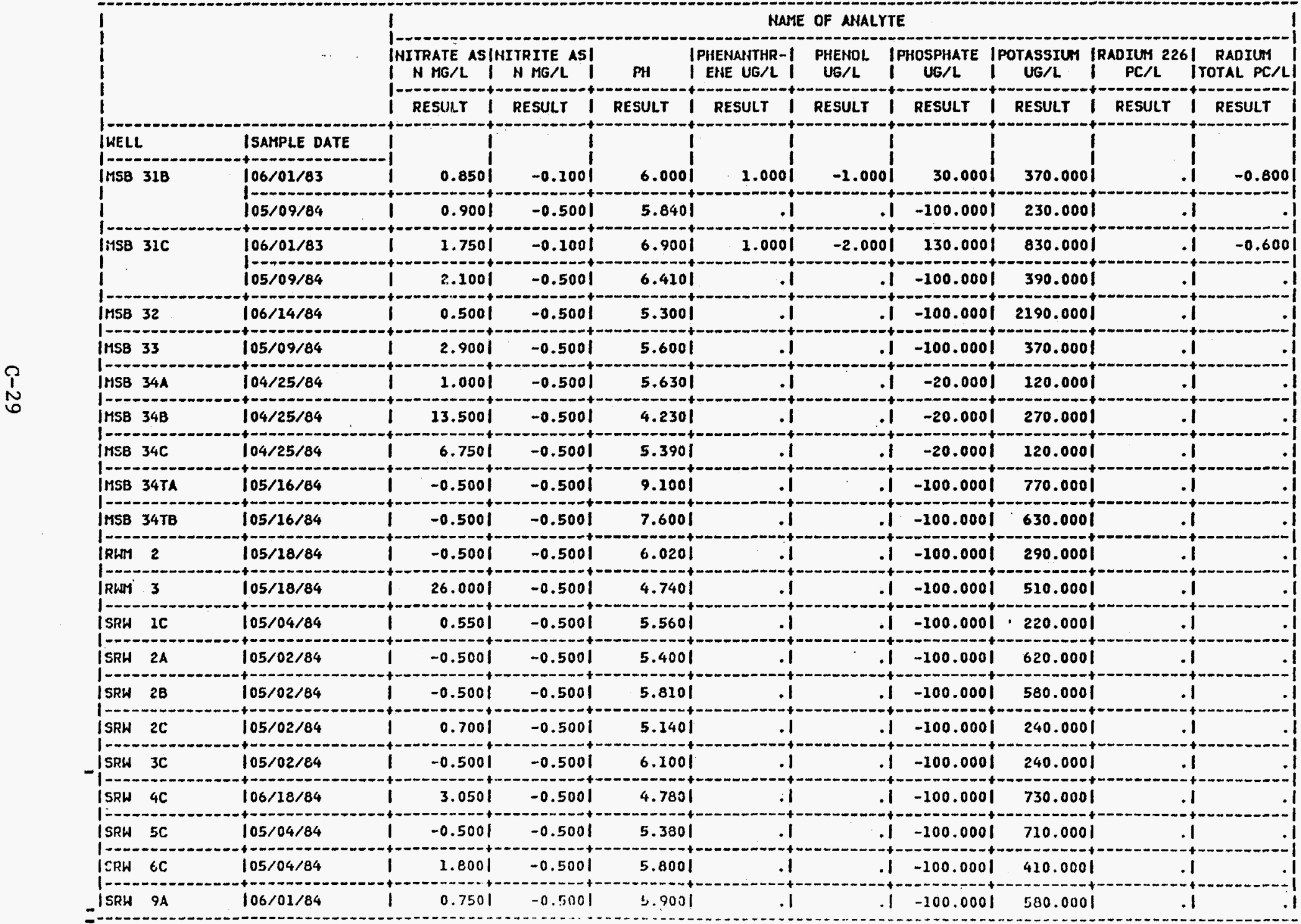

(COIT IINED) 
APPERDIX C. ANALYTES IN EACH WELL.

NEGATIVE IMURERS REPRESENT DETECTIONS LIMITS. DOTS REPRESENT ANULYSES NOT PERFORMED

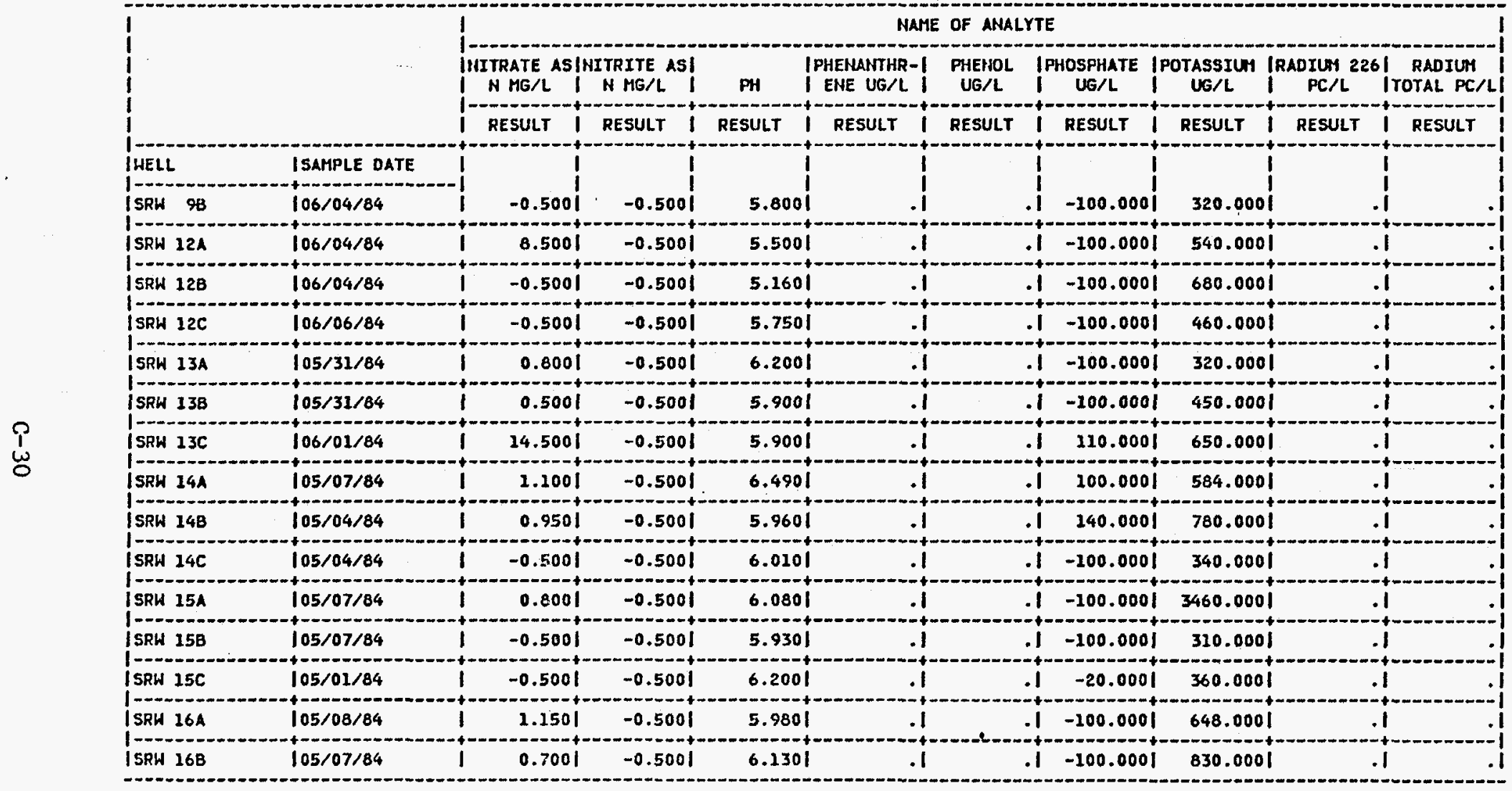


APPENDIX C. AHALTTES IN EACH WELL

NEGATIVE NUHBERS REPRESENT DETECTIONS LIMITS. DOTS REPRESENT ANALYSES NOT PERFORMED

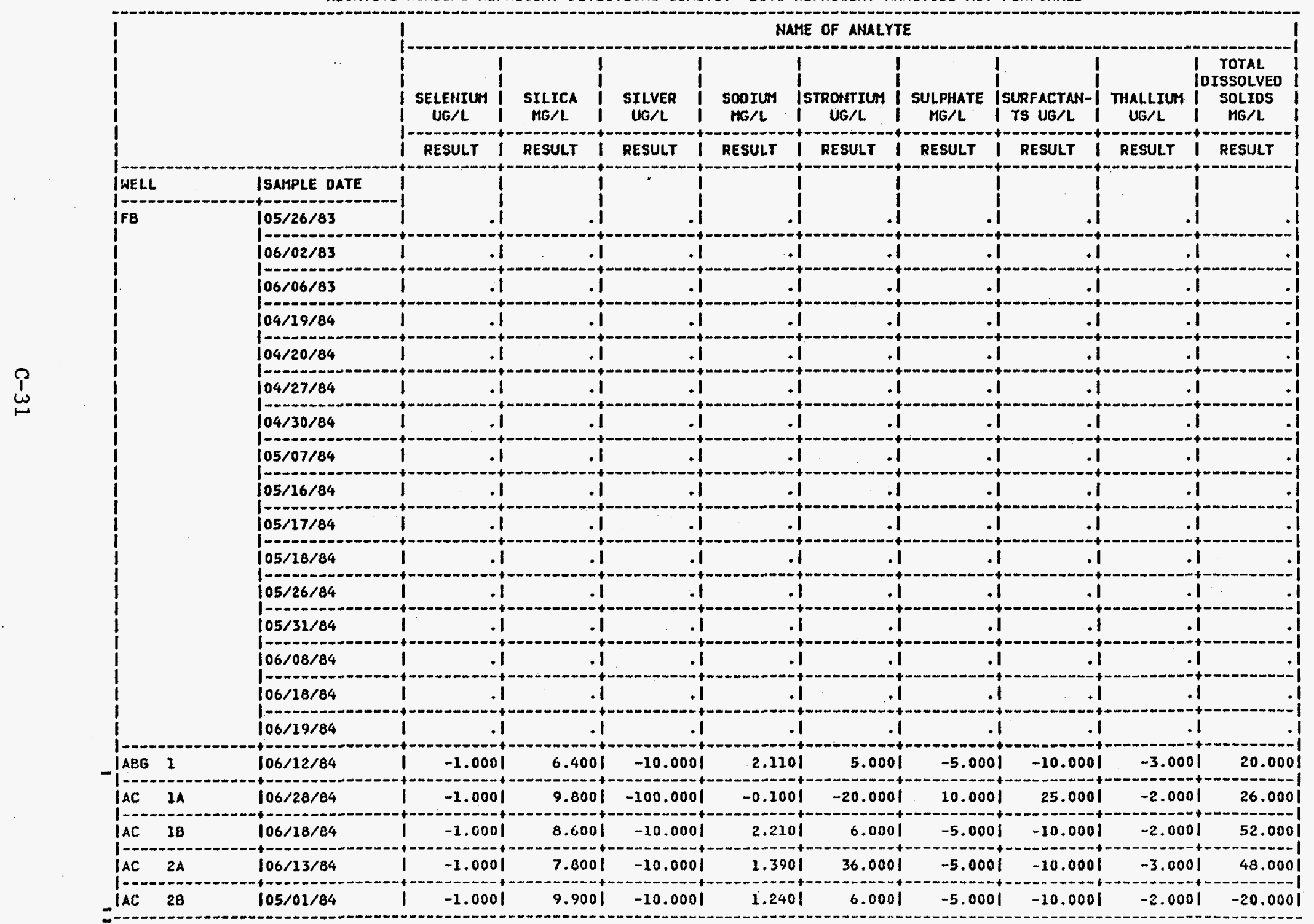

(COMTINUEO) 


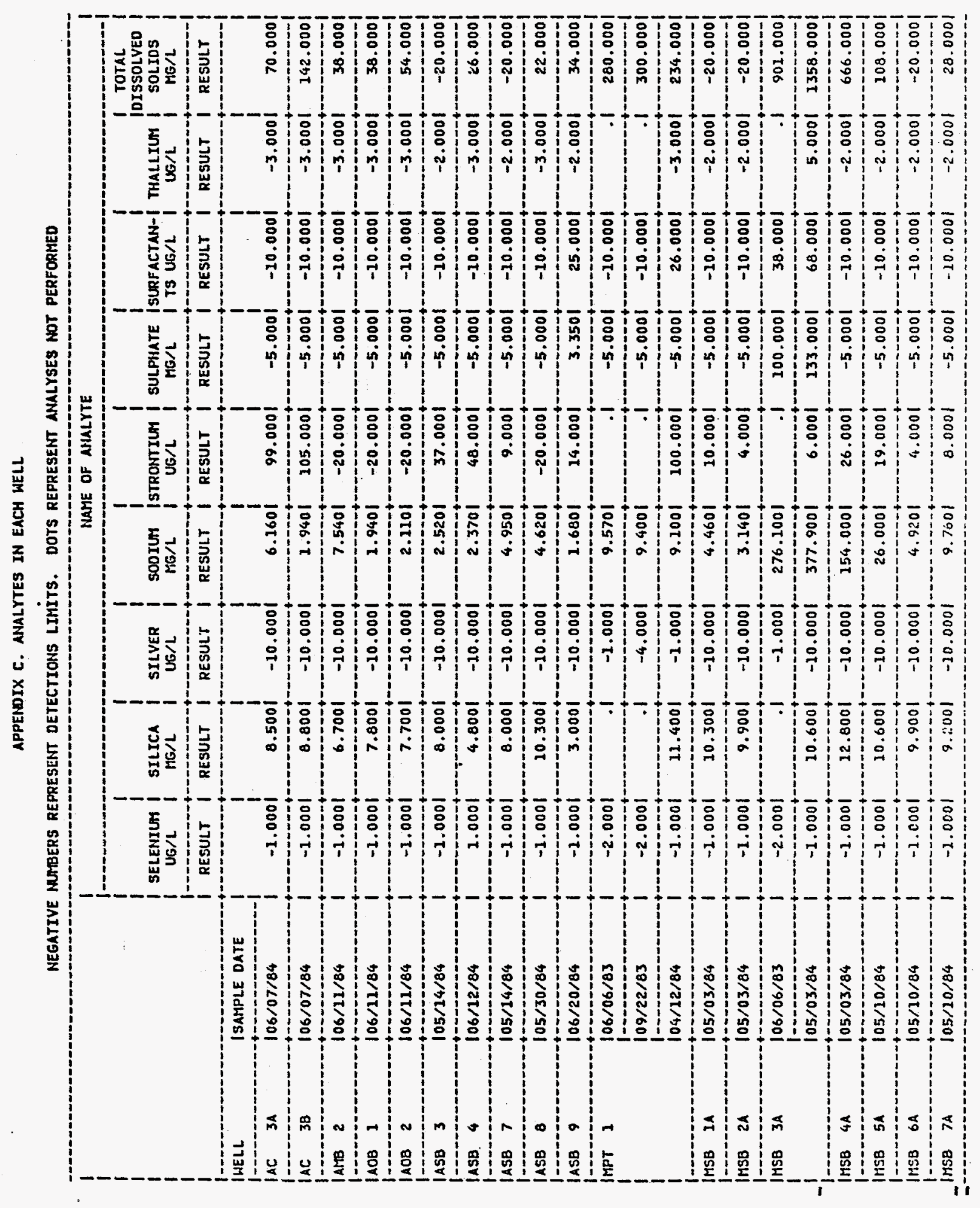


APPENDIX C, AHALYTES IN EACH WELL

NEGATIVE MURERS REPRESENT DETECTIONS LIMITS. DOTS REPRESENT MNALYSES NOT PERFORMED

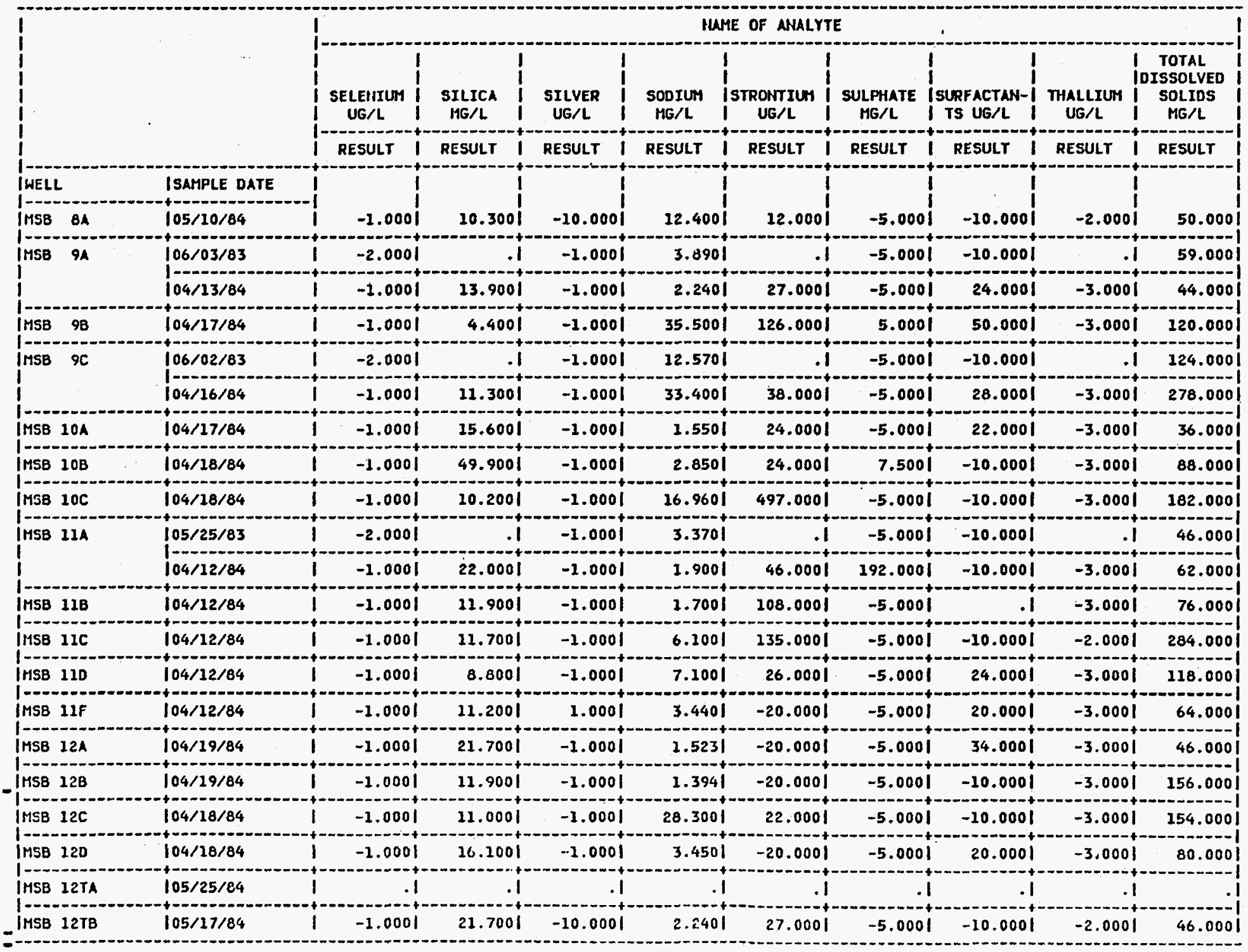

(CONTIHUED) 
APPENDIX C. ANALYTES IN EACH WELL.

NEGATIVE MUIBERS REPRESEIT DETECTIONS LIMITS. DOTS REPRESENT ANALYSES NOT PERFORMED

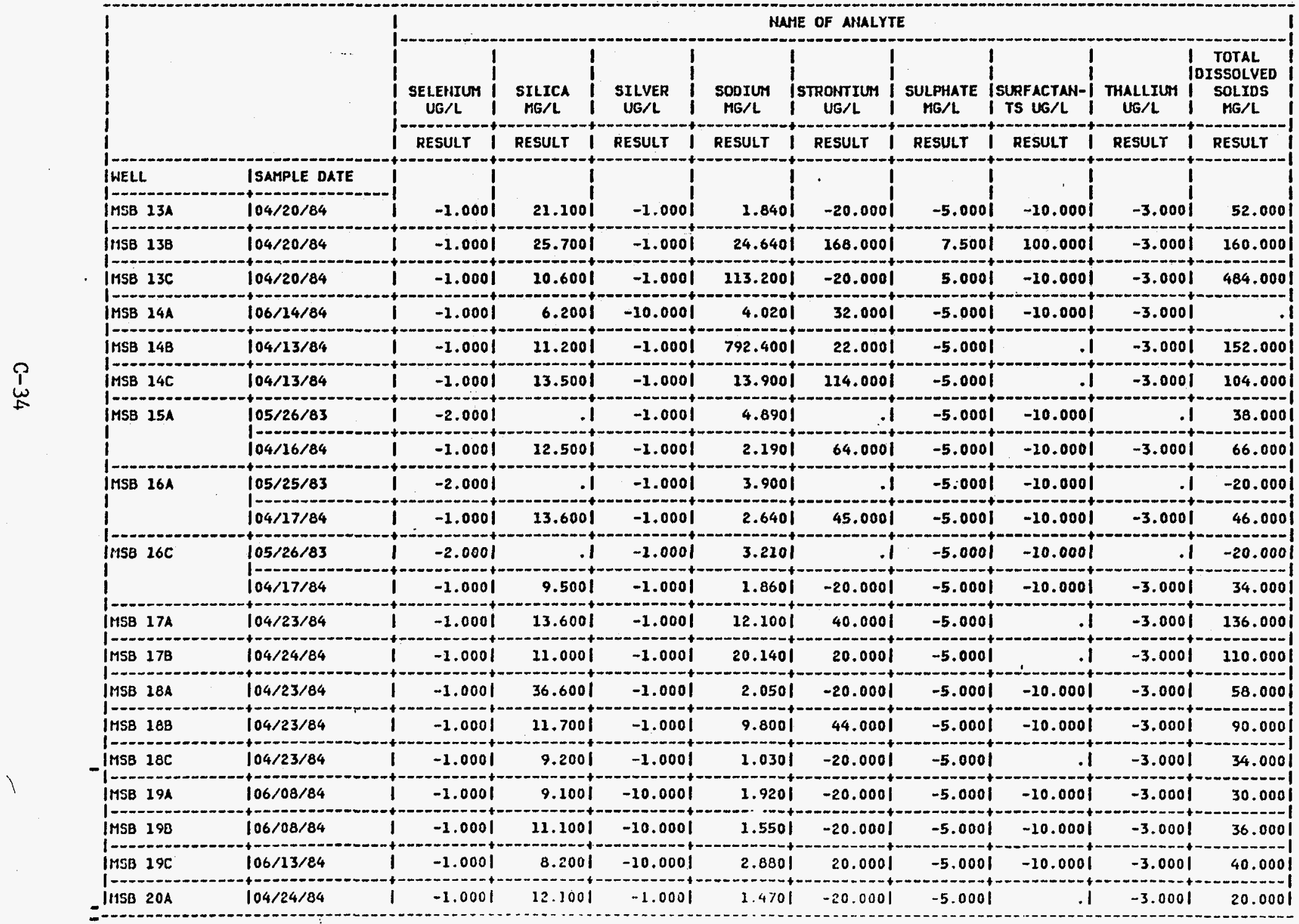

(COIT YHUED) 


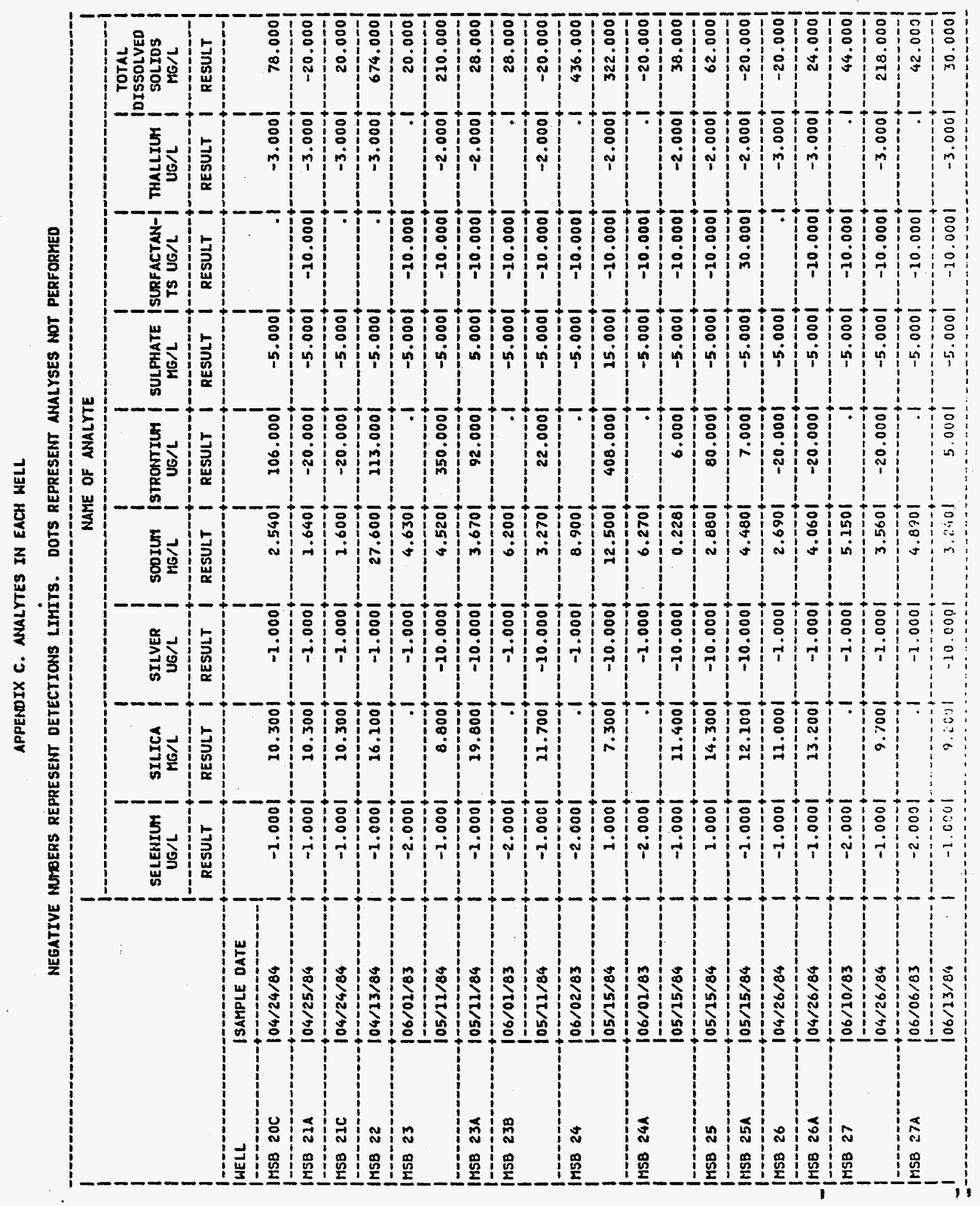


APPENDIX C. ANLLLTES IN EACH HELL

NEGATIVE MUMBERS REPRESENT DETECTIOHS LIMITS. DOTS REPRESENT ANALYSES NOT PERFORMED

\begin{tabular}{|c|c|c|c|c|c|c|c|c|c|c|}
\hline$?$ & & $\underset{\text { UEL } / L}{\operatorname{SenIUM}}$ & $\underset{M G / L}{\operatorname{SILICA}}$ & $\underset{\text { UG } / L}{\text { SILVER }}$ & $\begin{array}{c}\text { SOOIUM } \\
M G / L\end{array}$ & $\left|\begin{array}{c}\text { USTRONTILA } \\
\mid\end{array}\right|$ & $\underset{\text { SULPALE }}{\text { SUTE }}$ & $\begin{array}{l}\text { SURFACTAN-I } \\
\text { TS UG/L I }\end{array}$ & $\begin{array}{c}\text { THALLIUN } \\
\text { UG } / L\end{array}$ & $\begin{array}{c}\text { TOTAL } \\
\text { IOISSOLVEO } \\
\text { SOLIDS } \\
\text { MG/L }\end{array}$ \\
\hline & & RESULT & RESULT & RESULT & RESULT & SULT & ESULT & ESULT & ESULT & ESULT \\
\hline IELL. & $\begin{array}{l}\text { ISAMPLE DATE } \\
\text { 104/30/84 }\end{array}$ & $-1.000 i$ & 14.3001 & -10.0001 & 2.3601 & 53.0001 & -5.0001 & 26.0001 & -2.0001 & 72.000 \\
\hline SB $28 A$ & $104 / 30 / 84$ & -1.0001 & 12.7001 & -10.0001 & 1.9801 & 8.0001 & -5.0001 & -10.0001 & -2.0001 & 30.0001 \\
\hline SB 30A & $104 / 30 / 84$ & -1.0001 & 18.3001 & -10.0001 & 1.5401 & 7.0001 & -5.0001 & -10.0001 & -2.0001 & 44.0001 \\
\hline $15830 \mathrm{C}$ & $104 / 30 / 84$ & -1.0001 & 12.1001 & -10.0001 & $4.280 !$ & 496.0001 & 10.0001 & 38.0001 & -2.0001 & $100.000 !$ \\
\hline MSB 314 & $105 / 09 / 84$ & -1.0001 & 10.6001 & -10.0001 & 1.3201 & 5.0001 & -5.0001 & .1 & -2.0001 & -20.000 \\
\hline IM5B 31B & $106 / 01 / 83$ & -2.0001 & .1 & -1.0001 & 4.2901 &.$i$ & -5.0001 & -10.0001 & & 25.0001 \\
\hline & $105 / 09 / 84$ & -1.0001 & 11.0001 & -10.0001 & 1.8001 & 4.0001 & -5.0001 & -10.0001 & -2.0001 & -20.0001 \\
\hline IMSB 31C & $106 / 01 / 83$ & -2.0001 & .1 & -1.0001 & 8.9201 & .1 & -5.0001 & -10.0001 & i & 55.000 \\
\hline & $105 / 09 / 84$ & -1.0001 & $11.700 \mathrm{I}$ & -10.0001 & 4.5001 & $29.000 i$ & -5.0001 & -10.0001 & -2.0001 & -20.0001 \\
\hline MSB 32 & $106 / 14 / 84$ & -1.0001 & 6.5001 & -10.0001 & 3.6901 & -20.0001 & -5.0001 & -10.0001 & -3.0001 & 48.0001 \\
\hline 15833 & 105 & -1.0001 & 9.9001 & -20.0001 & 5.9501 & 6.0001 & -5.0001 & -10.0001 & -2.0001 & -20.0001 \\
\hline IMSB $34 A$ & $104 / 25 / 84$ & -1.0001 & 11.0001 & -1.0001 & 2.0901 & -20.0001 & -5.0001 & -10.0001 & -3.0001 & -20.0001 \\
\hline IMSB 34B & $104 / 25 / 84$ & -1.0001 & 9.9001 & -1.0001 & 3.6601 & 44.0001 & -5.0001 & -10.0001 & -3.0001 & $70.000 !$ \\
\hline IMSB 34C & $104 / 25 / 84$ & -1.0001 & 9.9001 & -1.0001 & 5.4601 & 30.0001 & -5.0001 & -10.0001 & -3.0001 & 52.0001 \\
\hline IMSB 34TA & $105 / 16 / 84$ & -1.0001 & $12.100 \mathrm{I}$ & -10.0001 & 2.9501 & 67.0001 & -5.0001 & -10.0001 & $-2.000 !$ & 56.0001 \\
\hline MISB $34 \mathrm{~TB}$ & $105 / 16 / 84$ & -1.0001 & 11.7001 & -10.0001 & 3.5301 & $20.000 i$ & -5.0001 & -10.0001 & -2.0001 & 42.0001 \\
\hline IRUH 2 & $105 / 18 / 84$ & .1 & 9.2001 & -10.0001 & 3.6701 & 4.0001 & -5.0001 & -10.0001 & -2.0001 & 34.0001 \\
\hline RWM 3 & $105 / 16 / 84$ & .1 & 12.1001 & -10.0001 & 3.8201 & 25.0001 & -5.0001 & -10.0001 & -2.0001 & $168.000 i$ \\
\hline SRH IC & $105 / 04 / 84$ & -1.0001 & 9.9001 & -10.0001 & 1.7501 & 8.0001 & -5.0001 & -10.0001 & -2.0001 & 22.0001 \\
\hline SRH $2 A$ & $105 / 02 / 84$ & -1.0001 & 16.0001 & -10.0001 & 1.5001 & $10.000 i$ & -5.0001 & $-10.000 i$ & -2.0001 & 36.000 \\
\hline ISRH 2B & $105 / 02 / 84$ & -1.0001 & 10.6001 & -10.0001 & 2.5801 & 22.0001 & -5.0001 & -10.0001 & -2.0001 & 36.0001 \\
\hline
\end{tabular}

(INNTINUED) 
APPENDIX C. ANALYTES IN EACH WELL

MEGATIVE MUREERS REPRESENT DETECTIOHS LIMITS. DOTS REPRESENT ANALYSES NOT PERFORHED

\begin{tabular}{|c|c|c|c|c|c|c|c|c|c|c|}
\hline ! & & $!$ & & & MaMt & IE OF ANALYTE & & & & \\
\hline & & $\mid \begin{array}{c}\text { SELENTIMY } \\
\text { UG/L }\end{array}$ & $\underset{M G / L}{\text { SILICA }}$ & $\begin{array}{c}\text { SILVER } \\
\text { UG } / L\end{array}$ & $\begin{array}{c}\text { Soorum } \\
\text { MG/L }\end{array}$ & $\begin{array}{c}\text { STRONTIUHA } \\
\text { UG/L }\end{array}$ & $\begin{array}{c}\text { SULPHATE } \\
\text { MG/L }\end{array}$ & $\begin{array}{l}\text { ISURFACTAN-I } \\
\text { TS UG/L I }\end{array}$ & $\underset{\text { UGLL }}{\text { THALIUM }}$ & $\begin{array}{l}\text { TOTAL } \\
\text { DISSOLVED } \\
\text { SOLIOS } \\
\text { MG/L }\end{array}$ \\
\hline & & RESULT & RESULT & RESULT & RESULT & RESULT & RESULT & RESULT & RESULT & RESULT \\
\hline IWELL & ISAMPLE DATE & i & & - in anol & & I & & i & 1 & \\
\hline ISRH 3C & $105 / 02 / 84$ & -1.0001 & 8.0001 & -10.0001 & 1.3201 & 4.0001 & -5.0001 & -10.0001 & -2.0001 & 24.0001 \\
\hline ISRW $4 \mathrm{C}$ & $106 / 28 / 84$ & -1.0001 & 9.3001 & -10.0001 & 4.4901 & 11.0001 & -5.0001 & -10.0001 & -2.0001 & 30.0001 \\
\hline SRH 5C & $105 / 04 / 84$ & -1.0001 & 17.4001 & .1 & 1.8601 & 6.0001 & -5.0001 & -10.0001 & -2.0001 & 38.0001 \\
\hline ISRW 6C & $105 / 04 / 84$ & -1.0001 & 20.9001 & -10.0001 & 3.6501 & 6.0001 & -5.0001 & -10.0001 & -2.0001 & 48.0001 \\
\hline ISRH 9A & $106 / 01 / 84$ & -1.0001 & 11.2001 & -10.0001 & 1.6601 & -20.0001 & -5.0001 & -10.0001 & -3.0001 & 20.0001 \\
\hline ISRH 9B & $106 / 04 / 84$ & -2.0001 & 10.6001 & -100.0001 & 2.8201 & -20.0001 & -5.0001 & -10.0001 & -3.0001 & -20.0001 \\
\hline ISRW I2A & $106 / 04 / 84$ & -1.0001 & 16.9001 & -100.0001 & 1.5901 & -20.0001 & -5.0001 & -10.0001 & -3.0001 & 26.0001 \\
\hline ISRW 12B & $106 / 04 / 84$ & -1.0001 & 8.8001 & -100.0001 & 1.2201 & -20.0001 & -5.0001 & -10.0001 & -3.0001 & -20.0001 \\
\hline ISRW I2C & $106 / 06 / 84$ & -1.0001 & 6.4001 & $-10.000 i$ & 2.4601 & -20.0001 & -5.0001 & -10.0001 & -3.0001 & 50.0001 \\
\hline SRW 13A & $105 / 31 / 84$ & -1.0001 & 13.2001 & -100.0001 & 1.6401 & -20.0001 & -5.0001 & -10.0001 & -3.0001 & -20.0001 \\
\hline ISRW 138 & $105 / 31 / 84$ & -1.0001 & 8.7001 & -10.0001 & 2.0801 & -20.0001 & -5.0001 & -10.0001 & -3.0001 & -20.0001 \\
\hline ISRW I3C & $106 / 01 / 84$ & -1.0001 & 12.5001 & -100.0001 & 4.6801 & -20.0001 & -5.0001 & -10.0001 & -3.0001 & 40.0001 \\
\hline ISRH I4A & $105 / 07 / 84$ & -1.0001 & 14.3001 & -10.0001 & 2.3901 & 48.0001 & -5.0001 & -10.0001 & -2.0001 & $52.000 i$ \\
\hline 15RH 148 & $105 / 04 / 84$ & -1.0001 & 11.7001 & -10.0001 & 5.1201 & 86.0001 & -5.0001 & -10.0001 & -2.0001 & 62.0001 \\
\hline JSRW $14 \mathrm{C}$ & $105 / 04 / 84$ & -1.0001 & 10.6001 & -10.0001 & 2.7701 & 9.0001 & -5.0001 & -10.0001 & -2.0001 & 36.0001 \\
\hline SRW 15A & $105 / 07 / 84$ & -1.0001 & 13.6001 & -10.0001 & 2.9501 & 504.0001 & -5.0001 & -10.0001 & -2.0001 & 64.000 \\
\hline ISRW 158 & $105 / 07 / 84$ & -1.0001 & 9.2001 & -10.0001 & 2.3501 & 13.0001 & -5.0001 & -10.0001 & -2.0001 & 32.0001 \\
\hline ISRH $15 \mathrm{C}$ & $105 / 01 / 84$ & -1.0001 & 10.3001 & -10.0001 & 2.7401 & 13.0001 & -5.0001 & -10.0001 & -2.0001 & $-20,0001$ \\
\hline ISPW IGA & $105 / 08 / 84$ & -1.0001 & 12.1001 & -10.0001 & 3.9201 & 17.0001 & -5.0001 & -10.0001 & -2.0001 & 24.0001 \\
\hline ISRW 16B & $105 / 07 / 84$ & -1.0001 & 10.3001 & -10.0001 & 3.8201 & 26,0001 & -5.0001 & -10.0001 & -2.0001 & 62.0001 \\
\hline
\end{tabular}




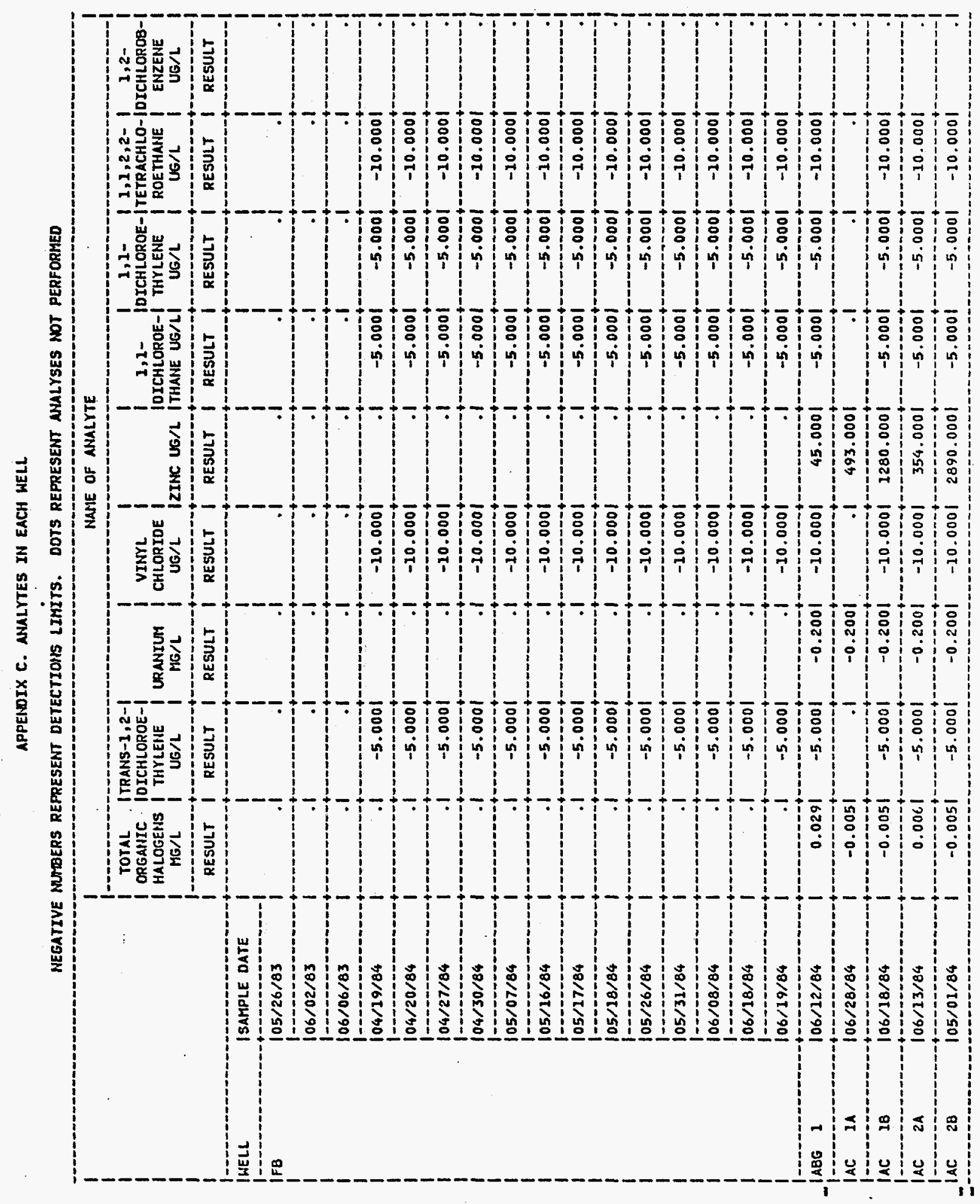

总 
APPENDIX C. ANALYTES IN EACH WELL NEGATIVE MUTBERS REPRESENT DETECTIONS LIMITS. DOTS REPRESENT ANALYSES NOT PERFORMED

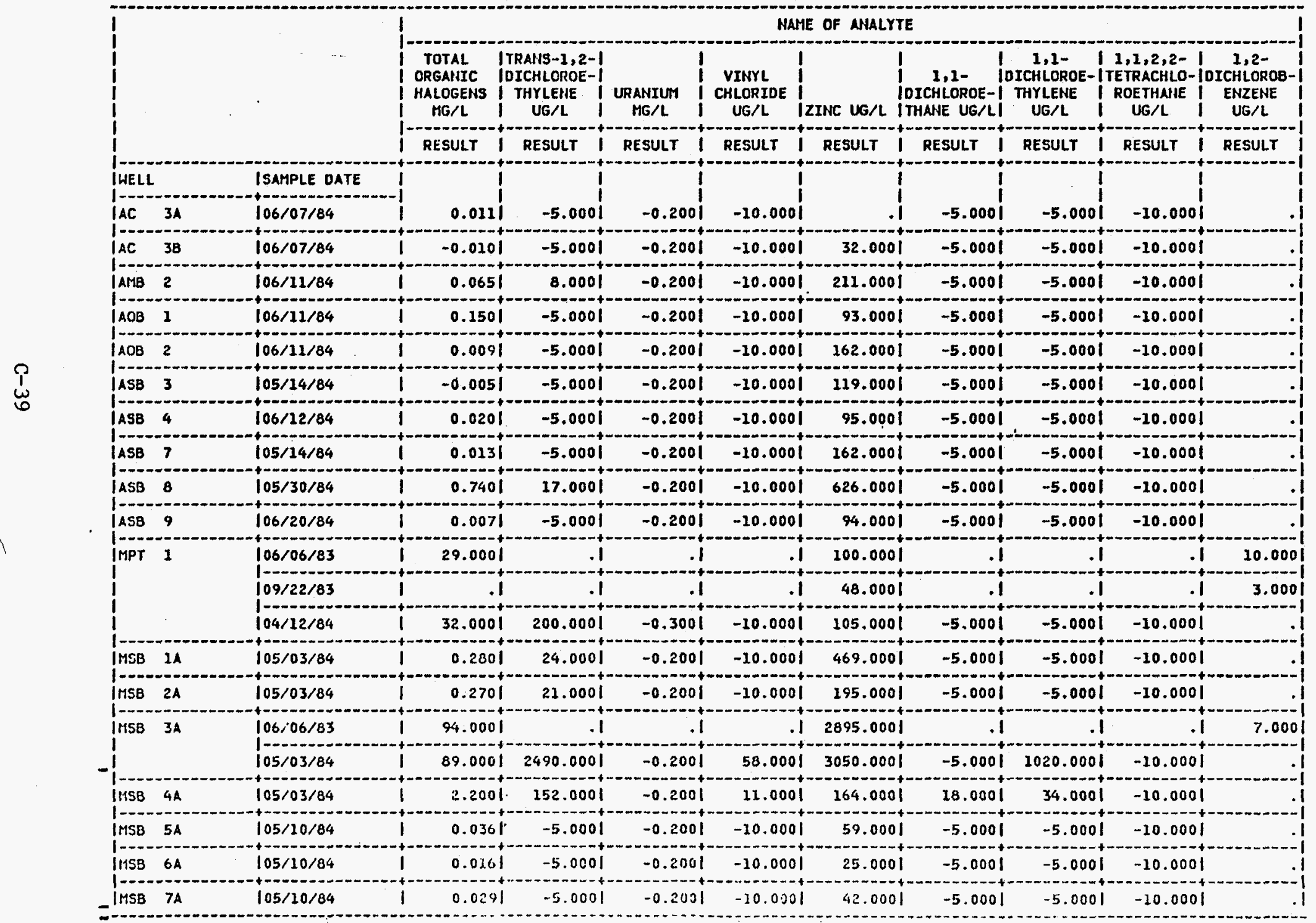

(CONT I PNUED) 
APPEHDIX C. ANALYTES IN EACH HELL

NEGATIVE MURBERS REPRESEHT DETECTIONS LIMITS. DOTS REPRESENT ANALYSES NOT PERFORMED

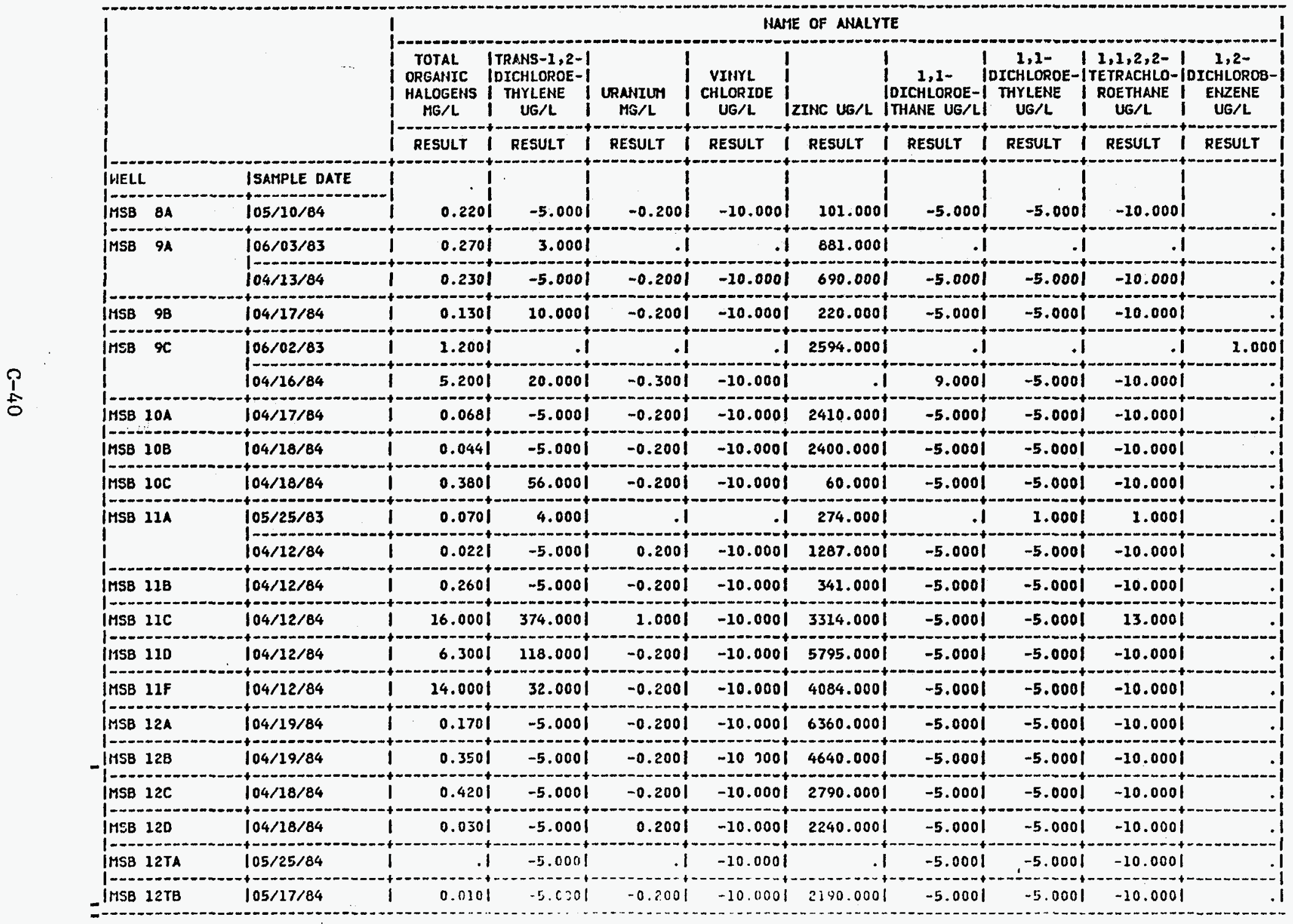

(COHTIIUED) 
APPENDIX C. NHALYTES IM EACH HELL

NEGATIVE MURBERS REPRESENT DETECTIONS LIMITS. DOTS REPRESENT ANALYSES NOT PERFORMED

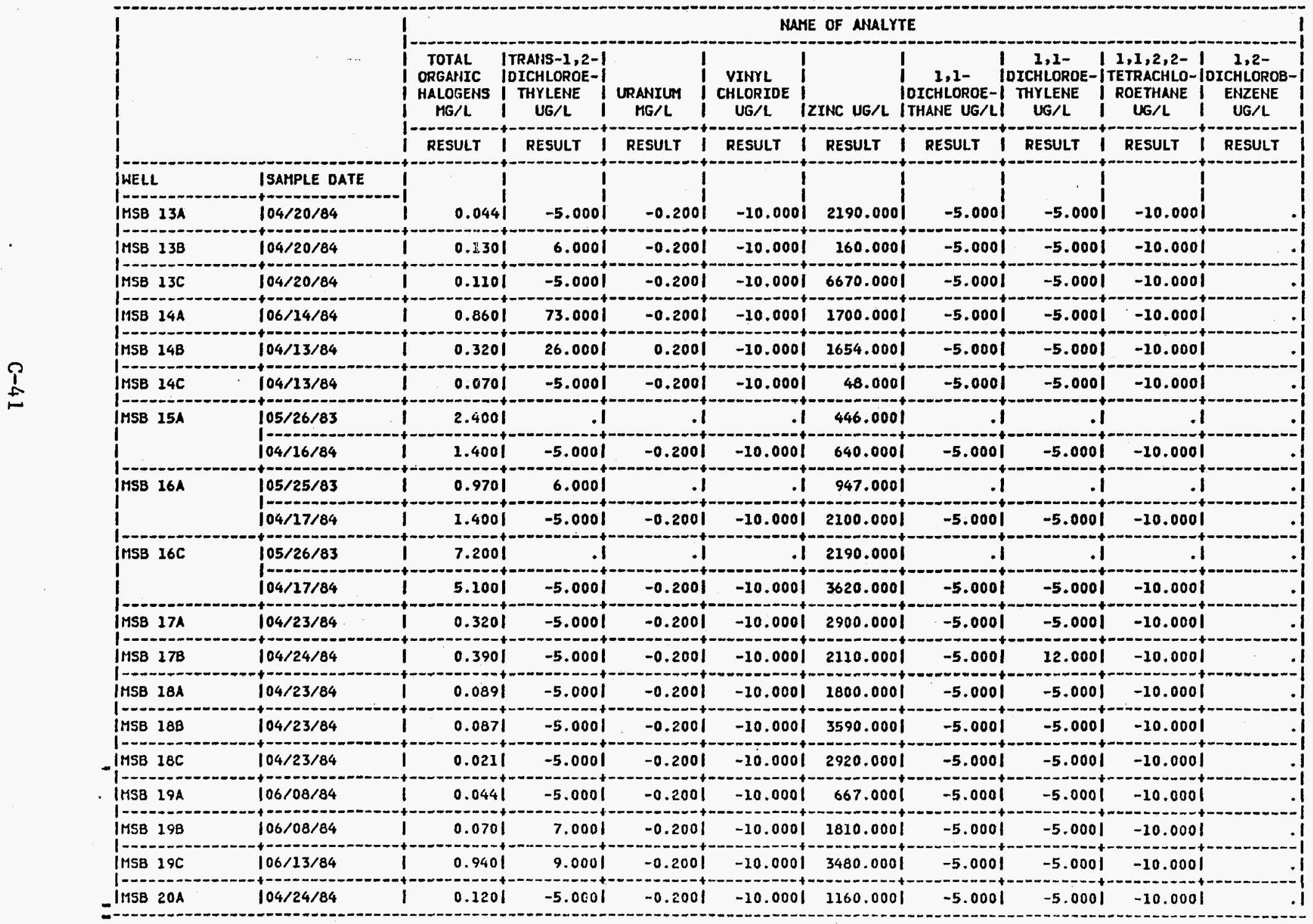

(CONTINNED.) 
APPENOIX C. MMALTTES IN EACH HELL.

MEGATIVE NUTHERS REPRESENT DETECTIONS LIMITS. DOTS REPRESENT ANALYSES NOT PERFORMED

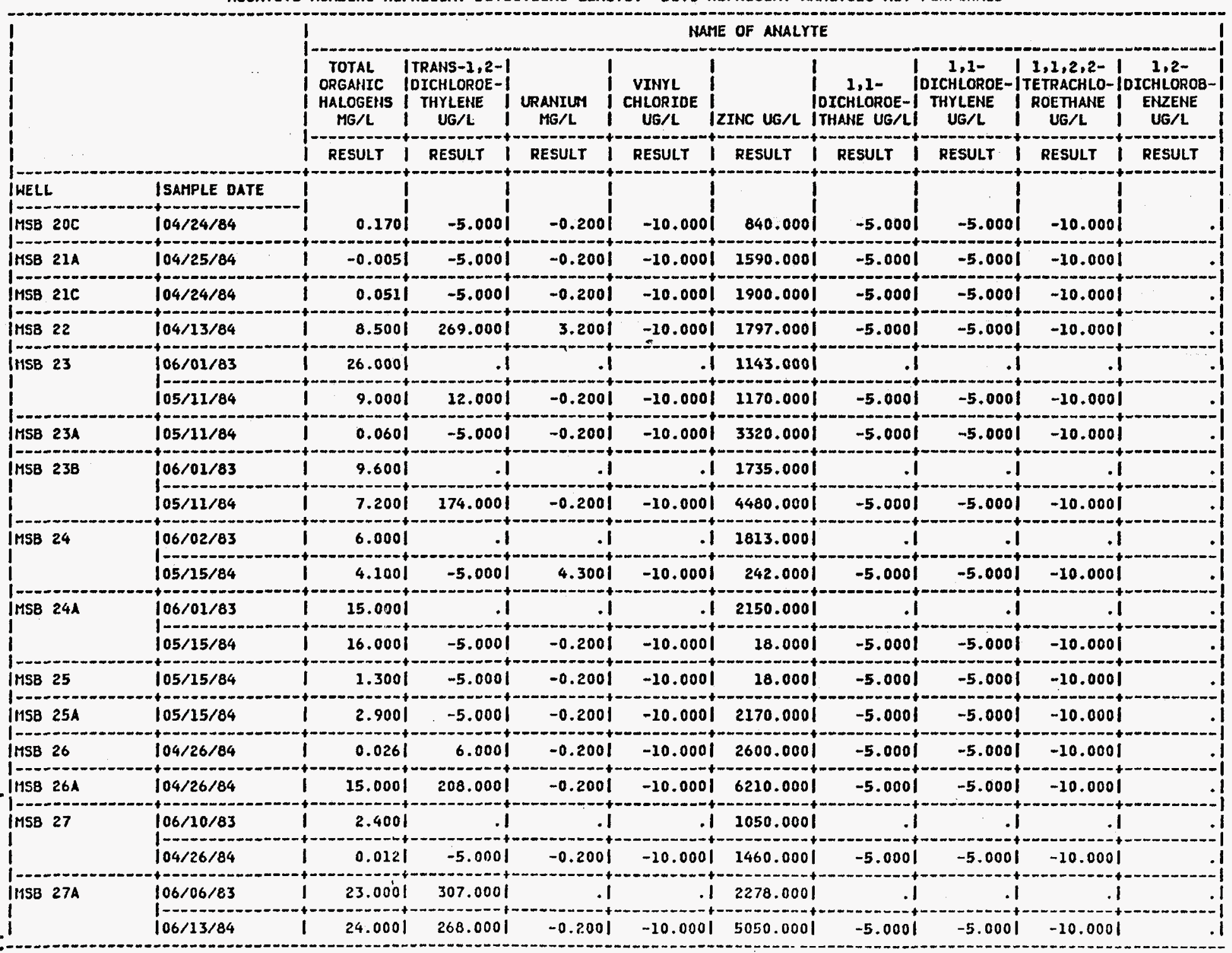

(CONT ITUED) 


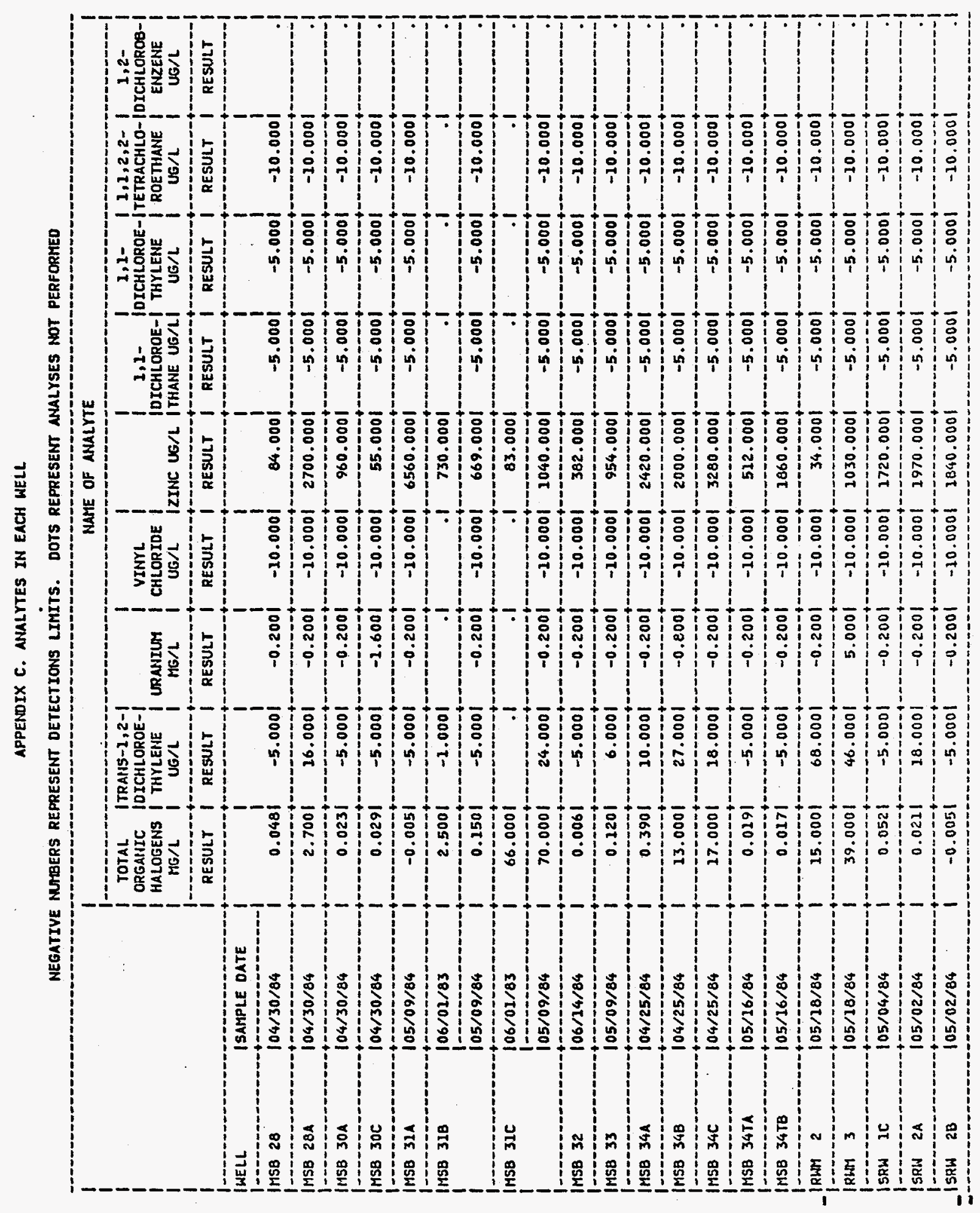

通 
APPERDIX C. ANALYTES IN EACH WELL

NEGATIVE MUEERS REPRESENT DETECTIONS LIMITS. DOTS REPRESENT ANALYSES NOT PERFORMED

\begin{tabular}{|c|c|c|c|c|c|c|c|c|c|c|}
\hline $\begin{array}{l}1 \\
1 \\
1\end{array}$ & & $\begin{array}{l}\text { TOTAL } \\
\text { ORGANIC } \\
\text { HALOGENS } \\
\text { MG/L }\end{array}$ & $\begin{array}{l}\text { TRANS-1,2-1 } \\
\text { IOYCHLOROE- } \\
\text { THYLEHE } \\
\text { UG } / L\end{array}$ & $\begin{array}{c}\text { URANIUNA } \\
\text { MG } / L\end{array}$ & $\begin{array}{c}\text { VINYL } \\
\text { CHLORIDE } \\
\text { UG/L }\end{array}$ & IE OF ANALYT & $\begin{array}{l}\text { TE } \\
1,1- \\
\text { IOICHLOROE-1 } \\
\text { ITHANIE UG } / \text { I }\end{array}$ & $\begin{array}{c}1,1- \\
\text { OICHLOROE- } \\
\text { THYLENE } \\
\text { UG/L }\end{array}$ & $\begin{array}{c}1,1,2,2-1 \\
\text { TETRACHLO-I } \\
\text { TOETHANE } \\
\text { UG/L }\end{array}$ & $\begin{array}{l}1,2- \\
\text { DICHLOROB- } \\
\text { ENLENE } \\
\text { UG/L }\end{array}$ \\
\hline & & RESULT & RESULT & RESULT & RESULT & ULT & RESULT & RESULT & RESULT & \\
\hline IWELL & ISAMPLE DATE & $!$ & 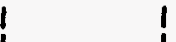 & & $!$ & 1 & $!$ & & & \\
\hline ISRH $2 C$ & $105 / 02 / 84$ & 0.041 & -5.0001 & -0.2001 & -10.0001 & 2340.0001 & -5.0001 & $-5.000 i$ & $-10.000 i$ & \\
\hline ISRW 3C & $105 / 02 / 84$ & 0.026 & -5.0001 & -0.3001 & -10.0001 & 5820.000 & -5.0001 & -5.0001 & -10.0001 & - \\
\hline ISRH 4C & $106 / 18 / 84$ & 0.025 & -5.0001 & 0.3001 & -10.0001 & 1820.0001 & -5.0001 & -5.0001 & $-10.000 i$ & \\
\hline ISRH 5C & $105 / 04 / 84$ & 0.120 & -5.0001 & -0.2001 & -20.0001 & 3960.0001 & -5.0001 & -5.0001 & -10.0001 & \\
\hline ISRW 6C & $105 / 04 / 84$ & 0.082 & -5.0001 & -0.2001 & -10.0001 & 2080.0001 & -5.0001 & -5.0001 & -10.0001 & - \\
\hline SRW 9A & $106 / 01 / 84$ & -0.005 & -5.0001 & -0.2001 & -10.0001 & 1410.0001 & -5.0001 & -5.0001 & -10.0001 & \\
\hline ISRH 98 & $106 / 04 / 84$ & -0.005 & -5.0001 & -0.2001 & -10.0001 & 1240.0001 & -5.0001 & -5.0001 & -10.0001 & \\
\hline ISRW I2A & $106 / 04 / 84$ & -0.005 & -5.0001 & -0.2001 & -10.0001 & 2400.0001 & -5.0001 & -5.0001 & -10.0001 & \\
\hline |SRW 12B & $106 / 04 / 84$ & 0.006 & -5.0001 & -0.2001 & -10.0001 & 1370.0001 & -5.0001 & -5.0001 & -10.0001 & \\
\hline SRH $12 \mathrm{C}$ & $106 / 06 / 84$ & -0.005 & -5.0001 & 0.2001 & -10.0001 & 764.0001 & -5.0001 & -5.0001 & -10.0001 & \\
\hline SRH 13A & $105 / 31 / 84$ & -0.005 & -5.0001 & -0.2001 & -10.0001 & 1550.0001 & $-5,0001$ & -5.0001 & -10.0001 & \\
\hline ISRH $23 B$ & $105 / 31 / 84$ & -0.005 & -5.0001 & -0.2001 & -10.0001 & 1530.0001 & -5.0001 & $-5.000 i$ & -10.0001 & \\
\hline ISRW 13C & $106 / 01 / 84$ & -0.005 & -5.0001 & -0.2001 & -10.0001 & 2810.0001 & -5.0001 & -5.0001 & $-10.000 i$ & - \\
\hline ISRH $24 A$ & $105 / 07 / 84$ & -0.005 & -5.0001 & -0.2001 & -10.0001 & 295.0001 & -5.0001 & -5.0001 & -10.0001 & \\
\hline ISRW 148 & $105 / 04 / 84$ & 0.029 & -5.0001 & 0.6001 & -10.0001 & 85.0001 & -5.0001 & -5.0001 & -10.0001 & \\
\hline ISRH 14C & $105 / 04 / 84$ & 0.046 & -5.0001 & -0.2001 & -10.0001 & 1600.0001 & -5.0001 & -5.0001 & -10.0001 & \\
\hline ISRH 15A & $105 / 07 / 84$ & 0.021 & -5.0001 & -0.2001 & -10.0001 & 56.0001 & -5.0001 & $-5.000 i$ & -10.0001 & \\
\hline ISRW 15B & $105 / 07 / 84$ & 0.076 & -5.0001 & $-0.200 i$ & -10.0001 & 1510.0001 & -5.0001 & $-5.000 i$ & -10.0001 & \\
\hline ISRW 15C & $105 / 01 / 84$ & -0.005 & -5.0001 &. .1 & -10.0001 & 917.0001 & -5.0001 & -5.0001 & -10.0001 & \\
\hline ISRW 16A & $105 / 08 / 84$ & 0.010 & -5.0001 & -0.2001 & -10.0001 & 2300.0001 & -5.0001 & -5.0001 & -10.0001 & \\
\hline ISRH 168 & $105 / 07 / 84$ & 0.003 & -5.0001 & -0.2001 & -10.0001 & 1090.0001 & -5.0001 & -5.0001 & -10.0001 & \\
\hline
\end{tabular}


APPENOIX C. ANALYTES IN EACH HELL

NEGATIVE MUNBERS REPRESENT DETECTIONS LIMITS. DOTS REPRESENT ANALYSES NOT PERFORMED

|


APPERDIX C. ANALYTES IN EACH MELL

NEGATIVE MUREERS REPRESENT DETECTIONS LIMITS. DOTS REPRESENT ANALYSES NOT PERFORMED

\begin{tabular}{|c|c|c|}
\hline I & & $\begin{array}{l}\text { NAME OF } \\
\text { AHALYTE } \\
1,4- \\
\text { IOICHLOROB- } \\
\text { EHIERE } \\
\text { UG/L } \\
\text { RESULT }\end{array}$ \\
\hline IWELL & ISAMPLE DATE & \\
\hline IAC & $105 / 01 / 84$ & 1 \\
\hline IAC $3 A$ & $106 / 07 / 84$ &. \\
\hline IAC $3 B$ & $106 / 07 / 84$ & . \\
\hline faMB 2 & $106 / 11 / 84$ & . \\
\hline IA0B 1 & $106 / 11 / 84$ & i \\
\hline $1408 \quad 2$ & $106 / 11 / 84$ & 1 \\
\hline$A 5 B$ & $105 / 14 / 84$ & -1 \\
\hline IASB 4 & $106 / 12 / 84$ & i \\
\hline IASB 7 & $105 / 14 / 84$ & . \\
\hline ASB 8 & $105 / 30 / 84$ & . \\
\hline IASB & $106 / 20 / 84$ & - \\
\hline InPT 1 & $106 / 06 / 83$ & 1.000 \\
\hline i & $109 / 22 / 83$ & -1.000 \\
\hline & $104 / 12 / 84$ & $i$ \\
\hline IMSB IA & $105 / 03 / 84$ & i \\
\hline ImsB 2A & $105 / 03 / 84$ & i \\
\hline IMSB $3 A$ & $106 / 06 / 83$ & - \\
\hline & $105 / 03 / 84$ & .1 \\
\hline IIISB $4 A$ & $105 / 03 / 84$ & 1 \\
\hline InSB 54 & $105 / 10 / 84$ & .1 \\
\hline
\end{tabular}




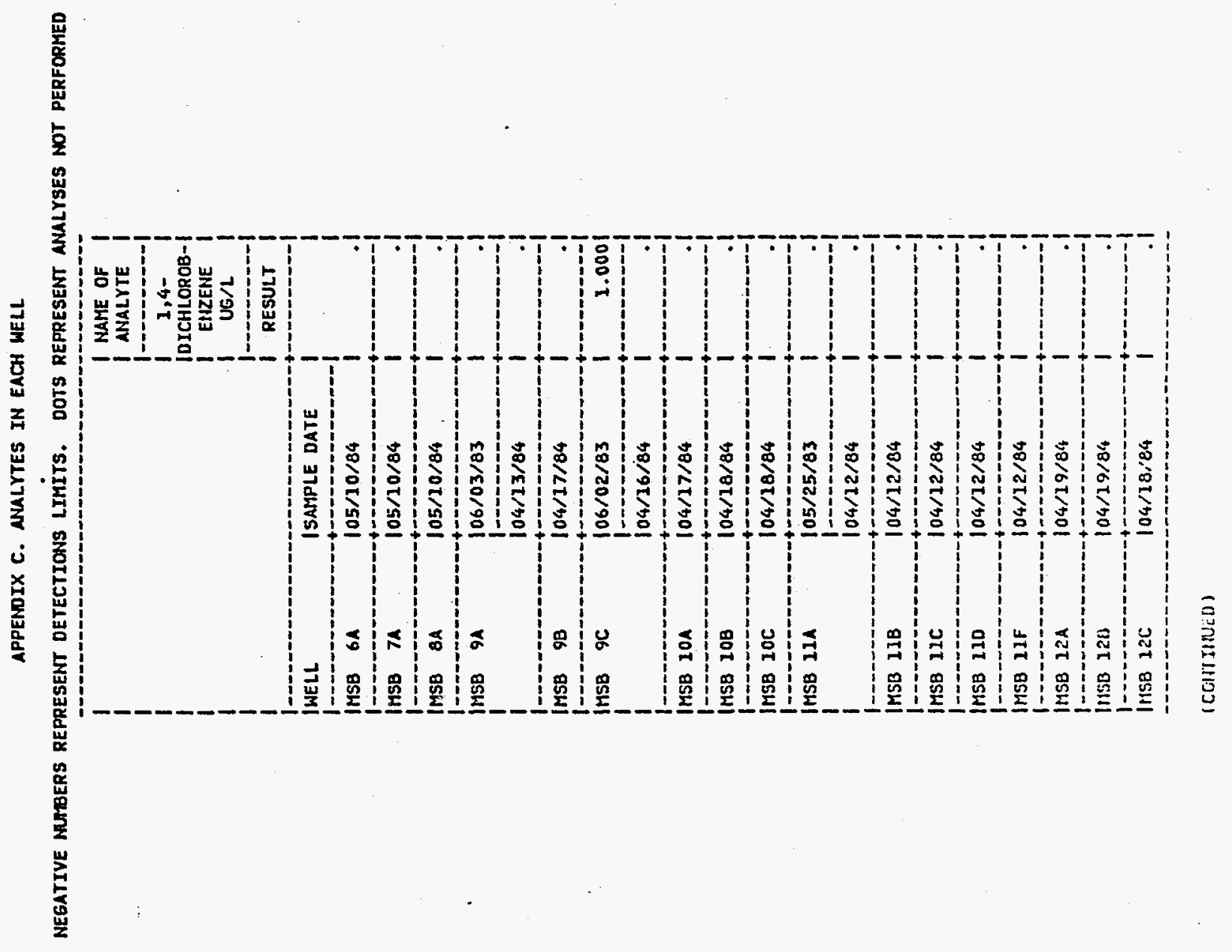


APPENDIX C. AMALTTES IN EACH WELL

MEGATIVE MUIBERS REPRESENT DETECTIONS LIMITS. DOTS REPRESENT ANALYSES NOT PERFORMED

\begin{tabular}{|l|l|}
\hline & I MAME OF \\
ANALYTE \\
\hline
\end{tabular}


APPENDIX C. ANALYTES IN EACH WELL

NEGATIVE MRRERS REPRESENT DETECTIONS LIMITS. DOTS REPRESENT ANALYSES NOT PERFCRMED

\begin{tabular}{|c|c|c|}
\hline . & & $\begin{array}{c}\text { MAME OF } \\
\text { ANALYTE } \\
1,4- \\
\text { DICHLOROB- } \\
\text { EHIZENE } \\
\text { UG/L } \\
\text { RESULT }\end{array}$ \\
\hline ÍWELL & Isample date & \\
\hline IMSB 19A & $106 / 08 / 84$ & \\
\hline MSB 198 & $106 / 08 / 64$ & 1 \\
\hline IMSB 190 & $106 / 13 / 84$ & \\
\hline MSB $20 A$ & $104 / 24 / 84$ & 1 \\
\hline IMsB $20 \mathrm{C}$ & $104 / 24 / 84$ & I \\
\hline IMSB 21A & $104 / 25 / 84$ & \\
\hline IMSB 21C & $104 / 24 / 84$ & i \\
\hline MSB 22 & $104 / 13 / 84$ & I \\
\hline 1 & $\begin{array}{l}06 / 01 / 83 \\
05 / 11 / 84\end{array}$ & \\
\hline MSB 23A & $105 / 11 / 84$ & I \\
\hline |IISB 23B & $06 / 01 / 83$ & 1 \\
\hline & $105 / 21 / 84$ & i \\
\hline IMSB 24 & $\begin{array}{l}06 / 02 / 83 \\
05 / 15 / 84\end{array}$ & i \\
\hline MSB 24A & $106 / 01 / 83$ & I \\
\hline & $105 / 15 / 84$ & i \\
\hline IISB 25 & $105 / 15 / 84$ & i \\
\hline MSB 25A & $105 / 15 / 84$ & i \\
\hline IMSB 26 & $104 / 26 / 84$ & 1 \\
\hline
\end{tabular}


APPENOIX C. MHALYTES IN EACH HELL

NEGATIVE MUBERS REPRESENT DETECTIONS I.IMITS. DOTS REPRESENT ANALYSES NOT PERFORMED

\begin{tabular}{|c|c|c|}
\hline & . & $\begin{array}{l}\text { NAME OF } \\
\text { AHALYTE } \\
1,4- \\
\text { DTCHLOROB- } \\
\text { ENZENE } \\
\text { UG/L }\end{array}$ \\
\hline & & \\
\hline IHELL & ISAMPLE DATE & \\
\hline IMSB 26A & $104 / 26 / 84$ &. \\
\hline IMSB 27 & $106 / 10 / 83$ &. \\
\hline & $104 / 26 / 84$ & . \\
\hline IMSB $27 A$ & $106 / 06 / 83$ &. \\
\hline & $106 / 13 / 84$ & i \\
\hline IIISB 28 & $104 / 30 / 84$ & .1 \\
\hline MSB $28 A$ & $104 / 30 / 84$ & . \\
\hline MSB $30 \mathrm{~A}$ & $104 / 30 / 84$ & . \\
\hline IMSB $30 \mathrm{C}$ & $104 / 30 / 84$ &. \\
\hline IMSB $31 \mathrm{~A}$ & $105 / 09 / 84$ & .1 \\
\hline MSB 31B & $106 / 01 / 83$ & . \\
\hline & $05 / 09 / 84$ & $i$ \\
\hline IMSB 31C & $106 / 01 / 83$ &. \\
\hline & $105 / 09 / 84$ & 1 \\
\hline i & & \\
\hline IMsB 32 & $106 / 14 / 84$ & i \\
\hline IMSB 33 & $105 / 09 / 84$ & 1 \\
\hline & & \\
\hline IHSB 34A & $104 / 25 / 84$ & I \\
\hline $1 M 58349$ & $104 / 25 / 84$ & 1 \\
\hline Inso $34 \mathrm{C}$ & $104 / 25 / 84$ & 1 \\
\hline $1 M 90$ 34 $1 \mathrm{~A}$ & $105 / 16 / 84$ & i \\
\hline
\end{tabular}




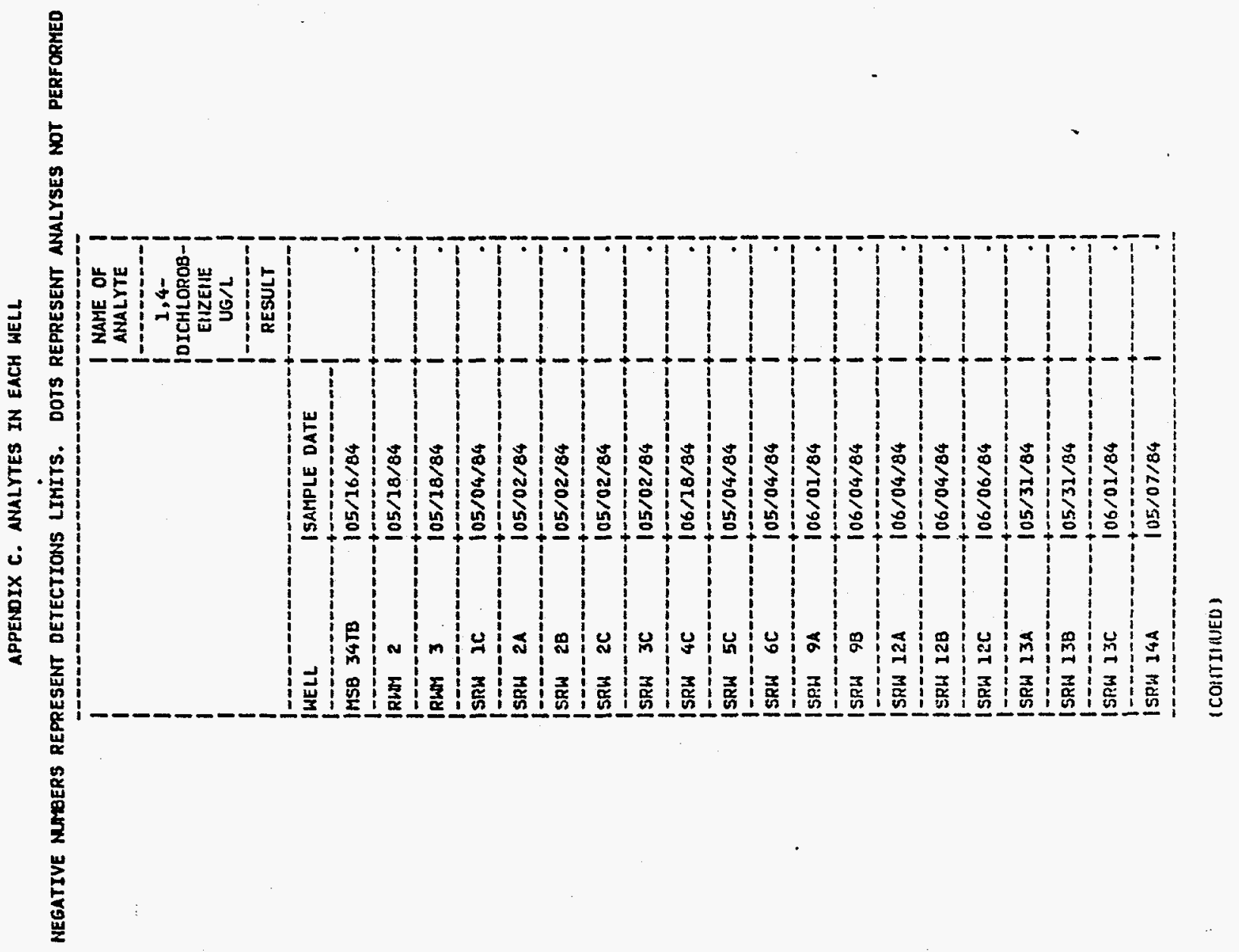


APPENDIX C. ANALYTES IN EACH WELL

NEGATIVE MUMBERS REPRESENT DETECTIONS LIMITS. DOTS REPRESENT ANALYSES NOT PERFORMED

\begin{tabular}{|c|c|c|}
\hline ! & & $\begin{array}{l}\text { NAME OF } \\
\text { ANALYTE } \\
\text { ANAT } \\
1,4- \\
\text { IOTCHLOROB- } \\
\text { ENZENE } \\
\text { UG/L } \\
\text { RESULT }\end{array}$ \\
\hline WELL & ISAMPLE DATE & \\
\hline ISRW 148 & $105 / 04 / 84$ & i \\
\hline ISRK 14C & $105 / 04 / 84$ & I \\
\hline SRW 15A & $105 / 07 / 84$ & $i$ \\
\hline ISRH 250 & $105 / 07 / 84$ & 1 \\
\hline ISRH 25C & $105 / 01 / 84$ & 1 \\
\hline SRW 16A & $105 / 08 / 84$ & $i$ \\
\hline ISRW 16B & $105 / 07 / 84$ & $i$ \\
\hline
\end{tabular}


APPENDIX D. RESULTS OF MONITORING WELL ANALYSES FOR M-AREA

Appendix $D$ contains a time sequence of analyses from watertable wells adjacent to the M-Area settling basin and Lost Lake. Although these wells are not as spacially distributed as those in Appendix $C$, the time sequence may be of value. The protocol for collecting these samples is given in Appendix E-3. 
Mrrustx $D$

Remits of Menltoring Well Aalyses for M-Area Settling Baln

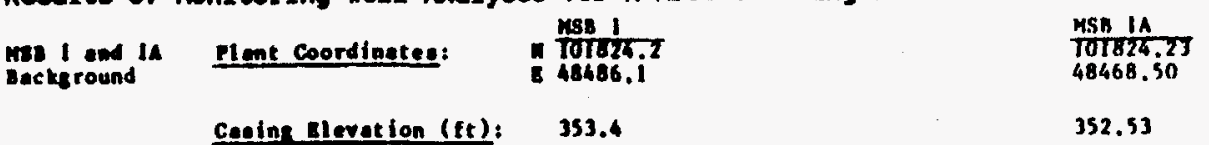

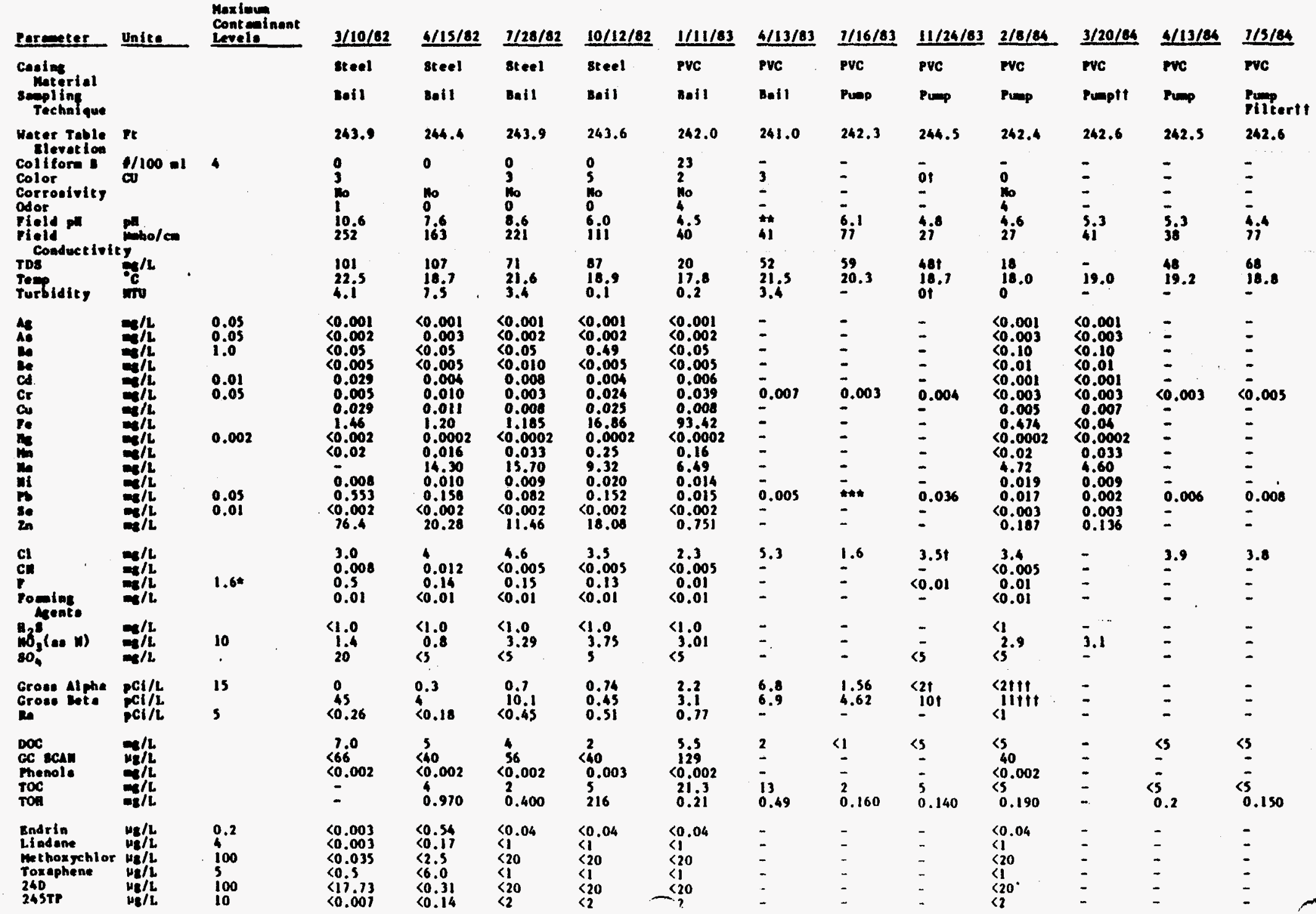


Arearorx D Contd

Recults of Monitoring Woll Analyses for M-Area Settling Dasin

\begin{tabular}{|c|c|c|c|}
\hline $\begin{array}{l}\text { HSI } 2 \text { and } 2 A \\
\text { Downg redient }\end{array}$ & Plont coordinetes: & 108741.92 & $\begin{array}{l}102021.39 \\
48746.0\end{array}$ \\
\hline & Geain Elevation (ft): & 352.3 & 351.72 \\
\hline
\end{tabular}

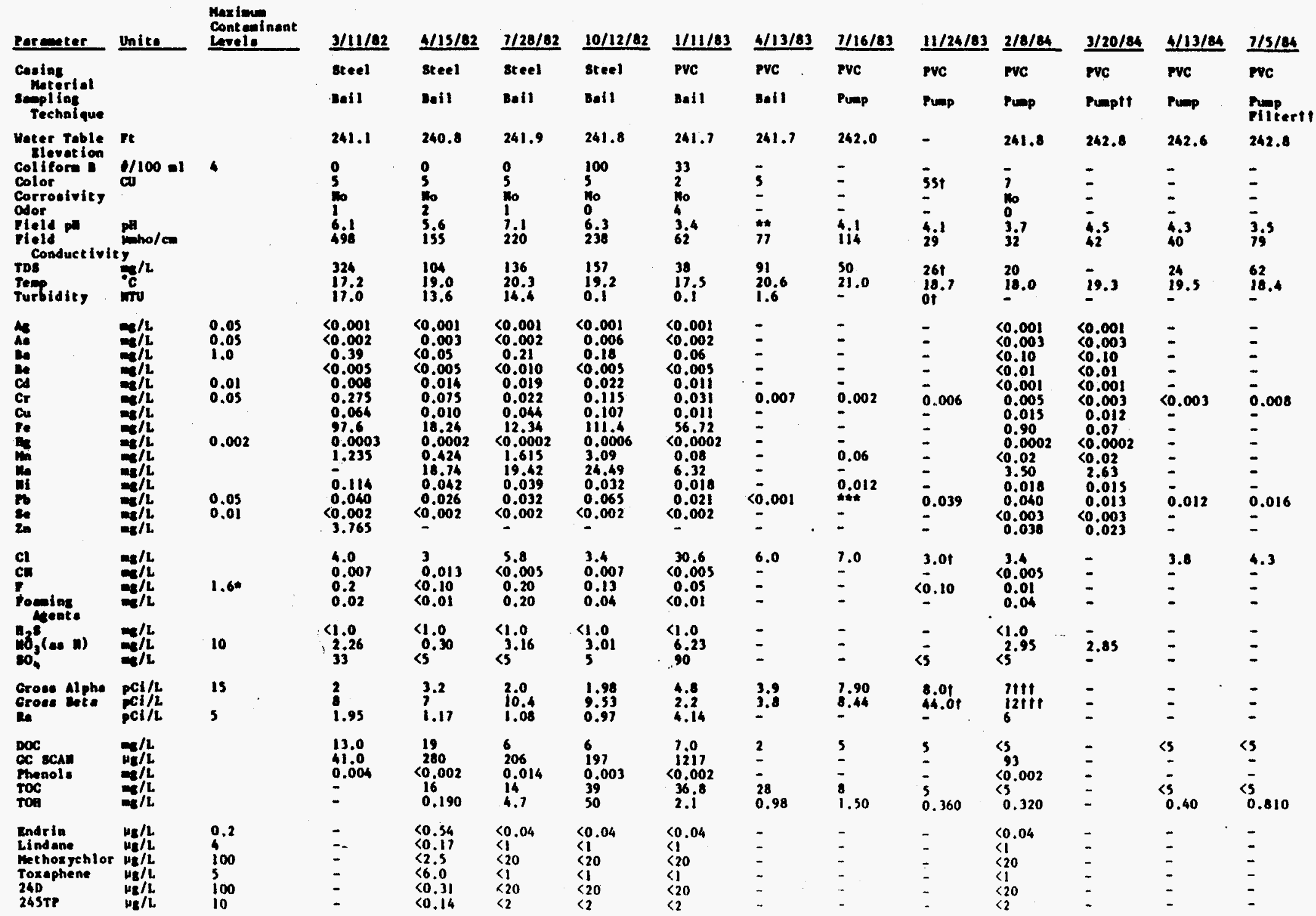


Nrmanix D Contd

Reaults of Monitoring Well Amalyses for M-Ares Settling Basin

\begin{tabular}{|c|c|c|c|}
\hline $\begin{array}{l}\text { mons } 3 \text { and } 3 A \\
\text { Doungredient }\end{array}$ & Plent Coordinetea: & a & $\begin{array}{l}\text { Msn } 34 \\
\text { T02751.57 } \\
48552.08\end{array}$ \\
\hline & Caeine slevation, (ft) & 359.6 & 359.03 \\
\hline
\end{tabular}

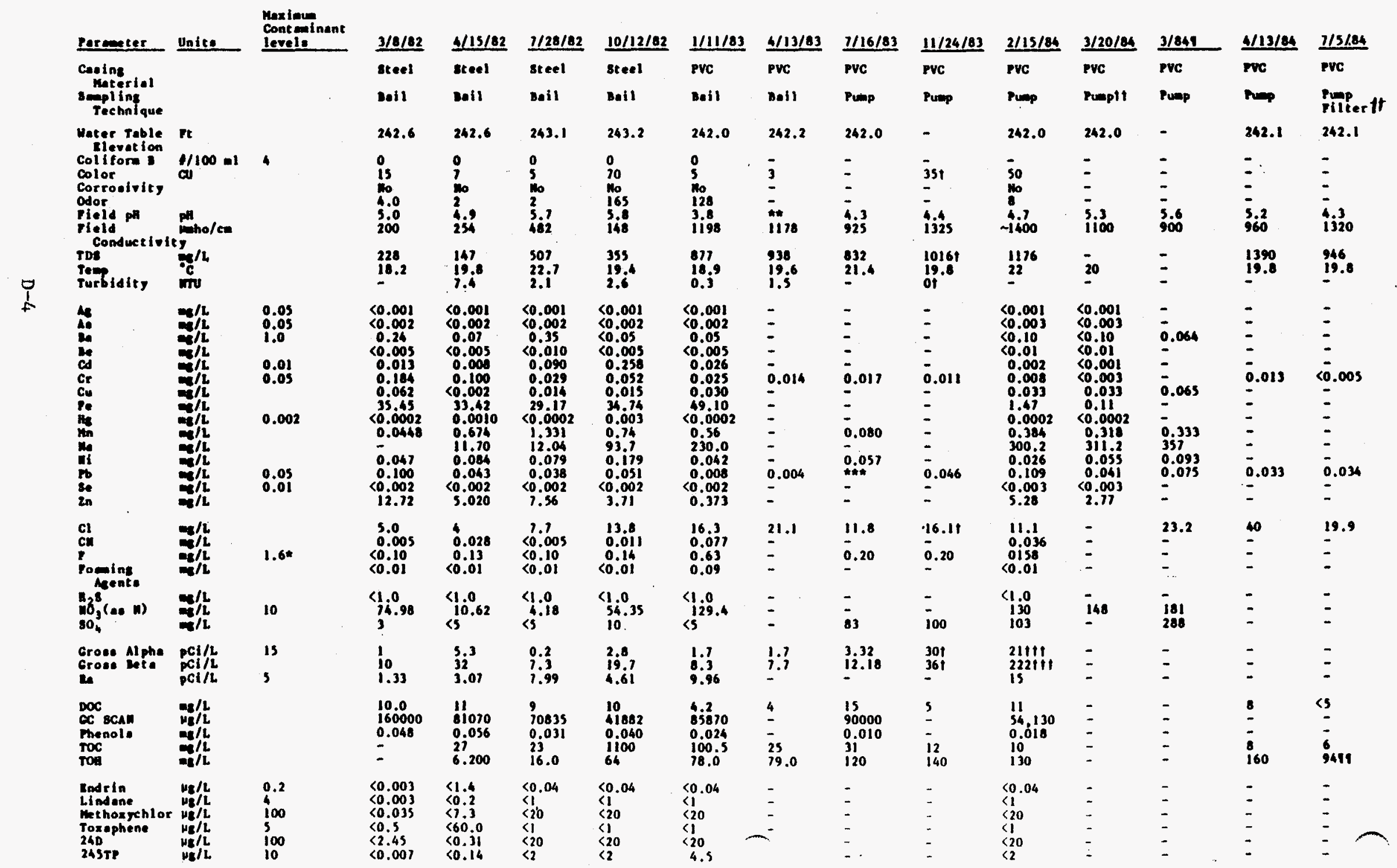


AppenoIX D Contd

Mesults of Monitoring Well Analyses for M-Area Settling Basin

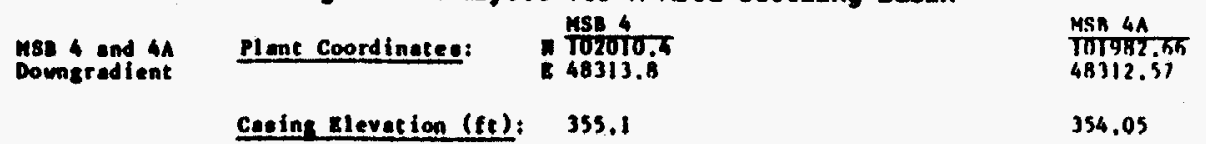

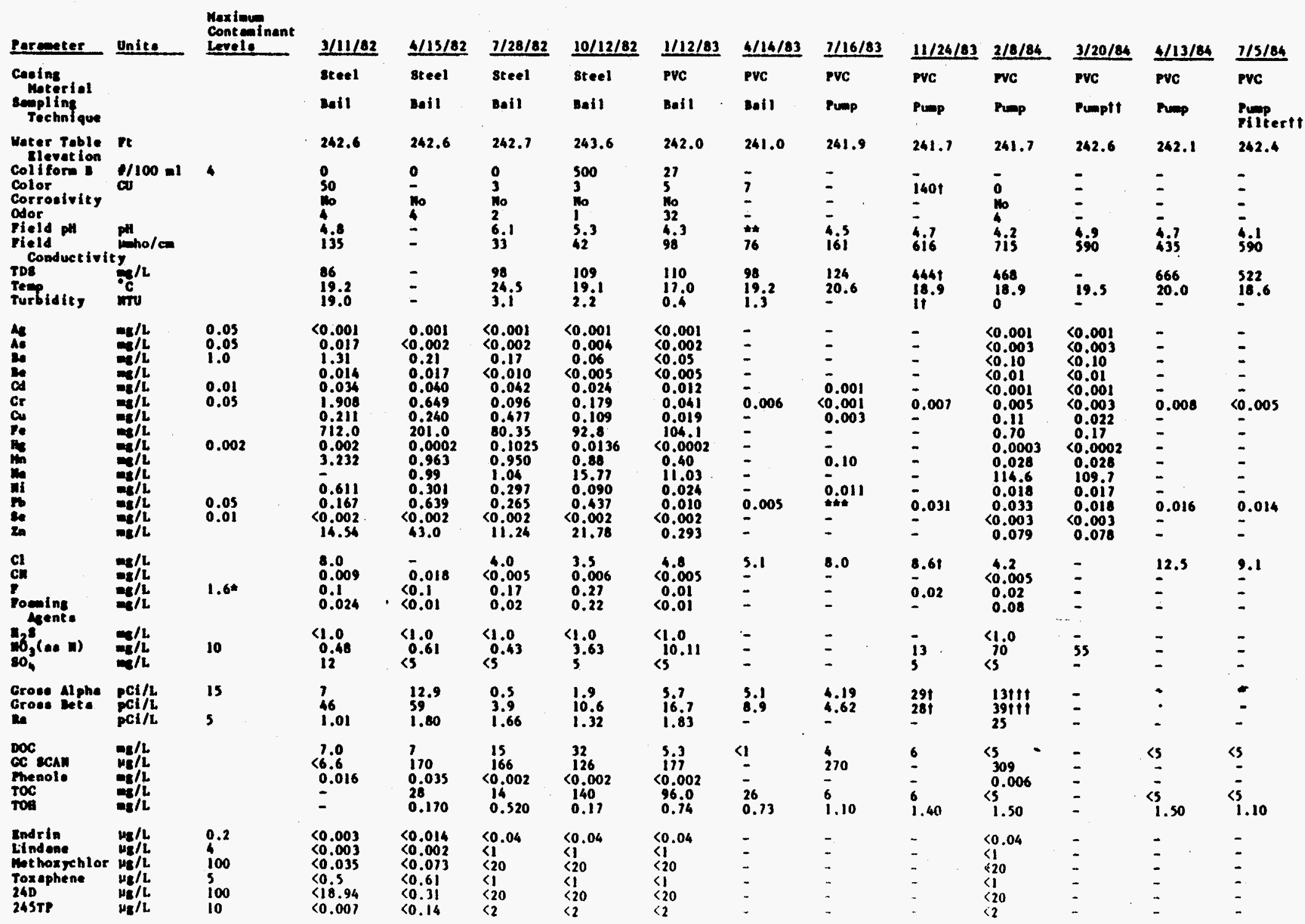




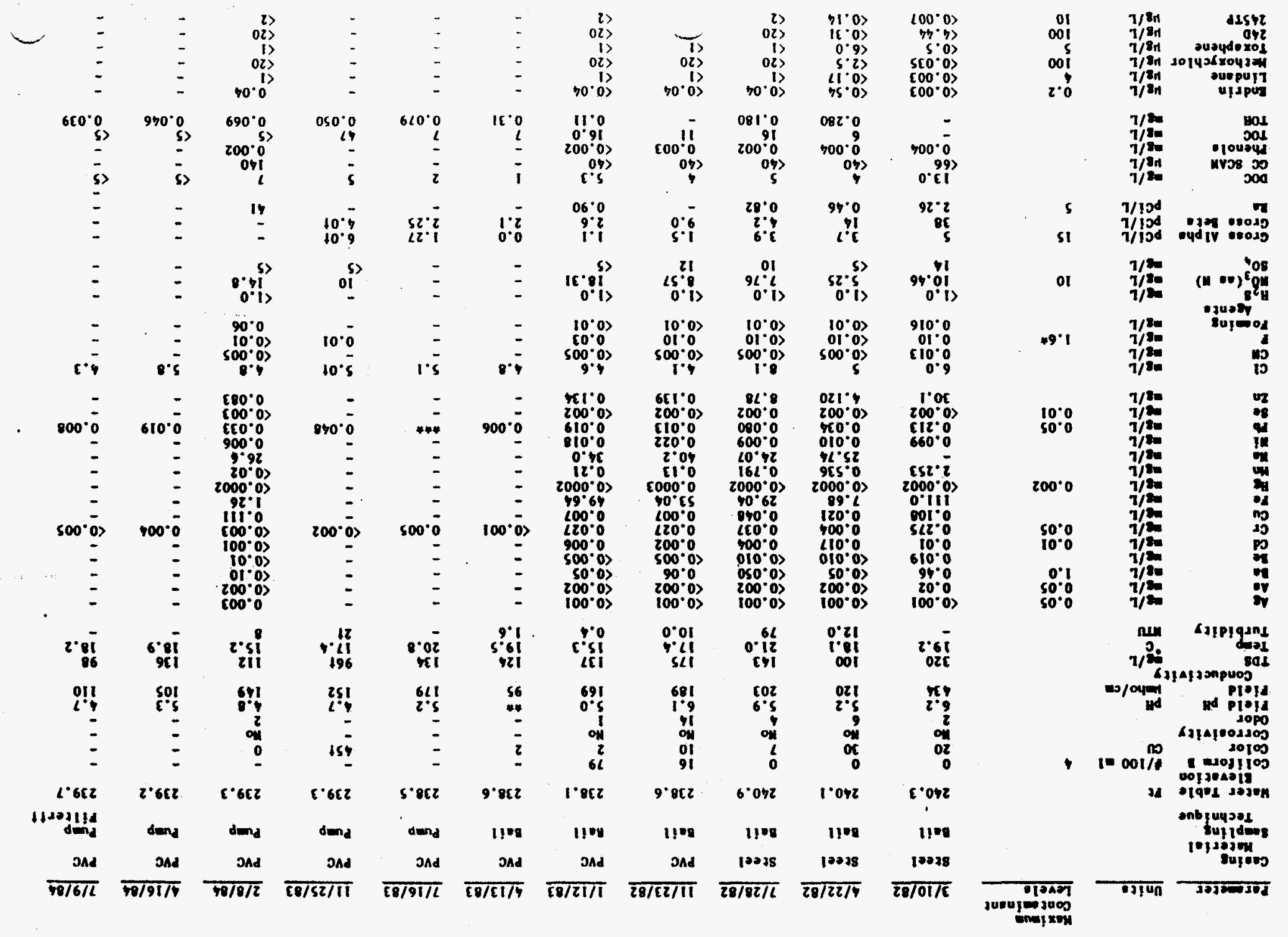

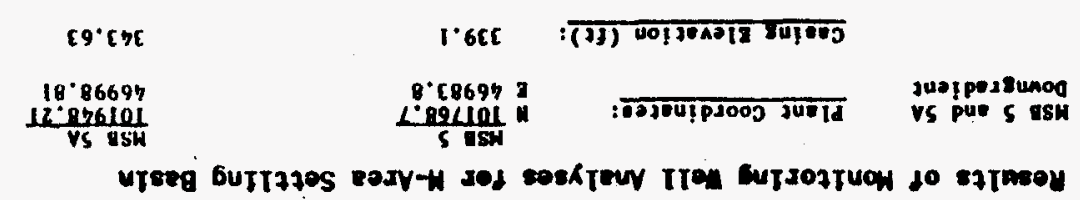

pauos da xioubdar 


\section{nppenoIX D Contd}

Reeults of Monitoring Woll Analyses for M-Area Sottling Basin

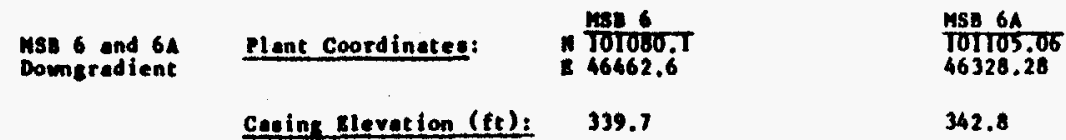

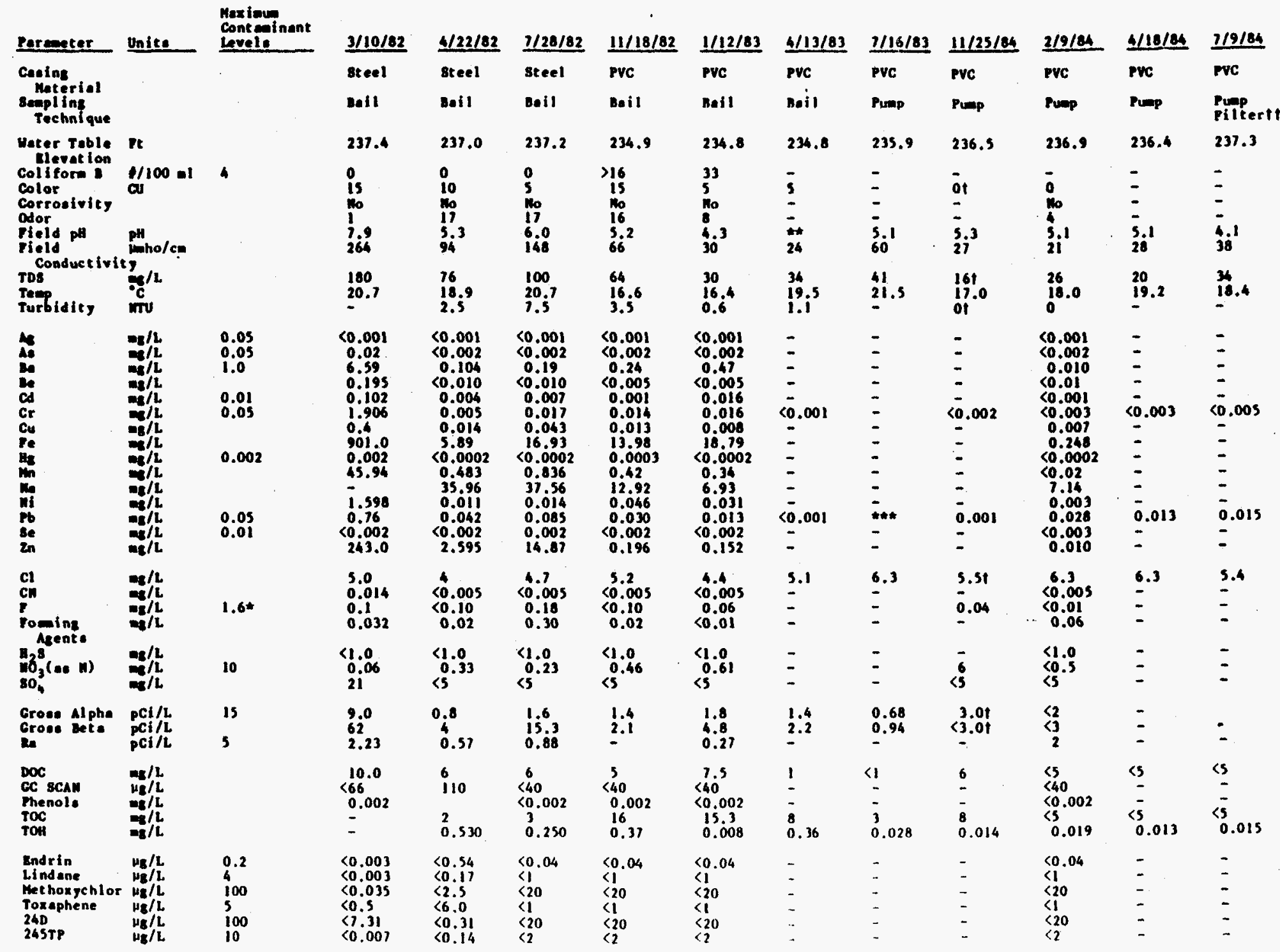


Aprandx Contd

Results of Monltoring Woll Analyees for M-Area Settling Basin

\begin{tabular}{|c|c|c|c|}
\hline \multirow[t]{2}{*}{$\begin{array}{l}\text { Mse } I \text { and } 7 \mathrm{~A} \\
\text { Downgredient }\end{array}$} & Plent Coordinates: & E 46785.9 & $\begin{array}{l}\text { MSs 7A } \\
100563.13 \\
46737.06\end{array}$ \\
\hline & & 340.7 & 343.93 \\
\hline
\end{tabular}

\begin{tabular}{|c|c|c|c|c|c|c|c|c|c|c|c|c|c|}
\hline Parcmeter & Unite & $\begin{array}{l}\text { Manimum } \\
\text { Cont minant } \\
\text { Levele } \\
\end{array}$ & $3 / 11 / 82$ & $4 / 22 / 82$ & $8 / 3 / 02$ & $11 / 18 / 82$ & $1 / 12 / 83$ & $4 / 13 / 83$ & $1 / 16 / 83$ & $11 / 25 / 84$ & $2 / 8 / 84$ & $413 / 84$ & $219 / 84$ \\
\hline $\begin{array}{l}\text { Cosing } \\
\text { raterial } \\
\text { seapling } \\
\text { Technique }\end{array}$ & & & $\begin{array}{l}\text { steel } \\
\text { Deil }\end{array}$ & $\begin{array}{l}\text { Steel } \\
\text { Bail }\end{array}$ & $\begin{array}{l}\text { steel } \\
\text { Dail }\end{array}$ & $\begin{array}{l}\text { PVC } \\
\text { Bail }\end{array}$ & $\begin{array}{l}\text { PVC } \\
\text { Bail }\end{array}$ & $\begin{array}{l}\text { PVC } \\
\text { Boil }\end{array}$ & $\begin{array}{l}\text { PVC } \\
\text { Pump }\end{array}$ & $\begin{array}{l}\text { Pvc } \\
\text { Puap }\end{array}$ & $\begin{array}{l}\text { Pve } \\
\text { Punp }\end{array}$ & $\begin{array}{l}\text { PNC } \\
\text { Punp }\end{array}$ & $\begin{array}{l}\text { Pvc } \\
\text { Pupp } \\
\text { Pilterit }\end{array}$ \\
\hline \multirow{3}{*}{ 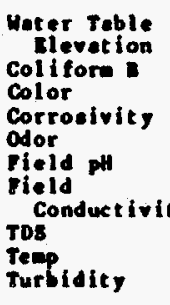 } & \multirow{3}{*}{ 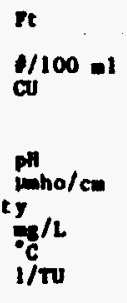 } & \multirow{3}{*}{4} & 237.7 & 238.7 & 239.2 & 231.5 & 237.4 & 236.4 & 237.0 & 238.7 & 238.8 & 231.9 & 238.6 \\
\hline & & & $\begin{array}{l}0 \\
10 \\
10 \\
4.9 \\
207\end{array}$ & $\begin{array}{l}0 \\
5 \\
10 \\
2 \\
5.4 \\
169\end{array}$ & $\begin{array}{l}0 \\
3 \\
\text { Mo } \\
2 \\
5 ; 9 \\
\text { iji }\end{array}$ & $\begin{array}{l}716 \\
15 \\
10 \\
16 \\
5.4 \\
74\end{array}$ & $\begin{array}{l}79 \\
2 \\
40 \\
4.5 \\
3 j\end{array}$ & $\begin{array}{l}\bar{z} \\
\bar{z} \\
21\end{array}$ & $\begin{array}{l}= \\
\vdots \\
\overline{9.9}\end{array}$ & $\begin{array}{l}\overline{0} \\
\overline{5} \\
5 ; 1 \\
3 i\end{array}$ & $\begin{array}{l}- \\
0 \\
10 \\
2.7 \\
6.7\end{array}$ & $\begin{array}{l}= \\
= \\
5.2 \\
50\end{array}$ & $\begin{array}{l}= \\
= \\
4.4\end{array}$ \\
\hline & & & $\begin{array}{l}186 \\
19.2\end{array}$ & $\begin{array}{l}117 \\
18.6 \\
2.2\end{array}$ & 19.9 & $\begin{array}{l}95 \\
16.7 \\
6.2\end{array}$ & $\begin{array}{l}36 \\
16.4 \\
0.5\end{array}$ & $\begin{array}{l}44 \\
18.8 \\
4.7\end{array}$ & $\begin{array}{l}66 \\
20.9\end{array}$ & $\begin{array}{l}60 t \\
18.3 \\
\text { of }\end{array}$ & $\begin{array}{l}54 \\
17.5 \\
0\end{array}$ & $\begin{array}{l}62 \\
18.5\end{array}$ & $\begin{array}{l}50 \\
11.9\end{array}$ \\
\hline \multirow{3}{*}{ 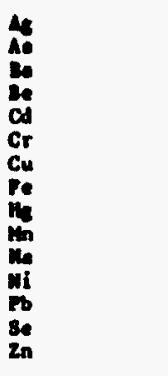 } & \multirow{3}{*}{$\begin{array}{l}m / L \\
m / L \\
m / L \\
m / L \\
m / L \\
m / L \\
m / L \\
m / L \\
m / L \\
m / L \\
m / L \\
m / L \\
m / L \\
m / L \\
m / L \\
m / L \\
a / L \\
m / L\end{array}$} & $\begin{array}{l}0.05 \\
0.05 \\
1.0\end{array}$ & $\begin{array}{c}<0.001 \\
0.006 \\
0.12\end{array}$ & \multirow{3}{*}{$\begin{array}{c}<0.001 \\
<0.002 \\
<0.050 \\
<0.010 \\
0.007 \\
0.025 \\
0.001 \\
6.240 \\
<0.0002 \\
0.620 \\
8.14 \\
1.051 \\
0.143 \\
<0.002 \\
2.110\end{array}$} & \multirow{3}{*}{$\begin{array}{l}<0.001 \\
<0.002 \\
<0.05 \\
<0.010 \\
0.016 \\
0.017 \\
0.014 \\
21.20 \\
<0.0002 \\
0.963 \\
4.02 \\
0.937 \\
0.031 \\
0.002 \\
1.964\end{array}$} & \multirow{3}{*}{$\begin{array}{c}<0.001 \\
<0.002 \\
0.26 \\
0.001 \\
0.002 \\
0.046 \\
0.010 \\
62.98 \\
0.0003 \\
0.31 \\
12.48 \\
0.024 \\
0.025 \\
<0.002 \\
0.173\end{array}$} & \multirow{3}{*}{$\begin{array}{c}<0.001 \\
<0.002 \\
0.46 \\
<0.005 \\
0.025 \\
0.040 \\
0.009 \\
48.14 \\
<0.0002 \\
0.17 \\
5.45 \\
0.023 \\
0.020 \\
<0.002 \\
0.121\end{array}$} & $=$ & $\overline{-}$ & $=$ & $\begin{array}{l}<0.001 \\
<0.002 \\
<0.10\end{array}$ & $=$ & : \\
\hline & & $\begin{array}{l}0.01 \\
0.05 \\
0.002\end{array}$ & $\begin{array}{l}0.006 \\
0.158 \\
0.015 \\
0.016 \\
37.23 \\
0.0002 \\
2.265\end{array}$ & & & & & $\begin{array}{l}\overline{0} \\
\overline{0} .012 \\
\overline{-} \\
\overline{-}\end{array}$ & $\begin{array}{l}\overline{0} \\
\overline{0} .003 \\
\overline{-}\end{array}$ & $\begin{array}{l}= \\
0.014 \\
= \\
=\end{array}$ & $\begin{array}{c}<0.01 \\
<0.001 \\
<0.003 \\
0.007 \\
0.284 \\
0.0002 \\
0.026\end{array}$ & $\begin{array}{l}E \\
0.004 \\
= \\
=\end{array}$ & $\begin{array}{l} \pm \\
0.010 \\
=\end{array}$ \\
\hline & & $\begin{array}{l}0.05 \\
0.01\end{array}$ & $\begin{array}{r}0.978 \\
0.026 \\
<0.002 \\
9.72\end{array}$ & & & & & $\bar{E} \overline{0} 011$ & 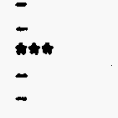 & $\begin{array}{l}\overline{-} \\
0.003 \\
-\end{array}$ & $\begin{array}{r}12.58 \\
<0.003 \\
0.023 \\
<0.003 \\
0.026\end{array}$ & $\begin{array}{l}\bar{E} \\
\overline{0} .010 \\
\overline{-}\end{array}$ & $\overline{0}$ \\
\hline \multirow{2}{*}{ 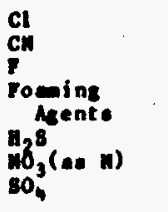 } & 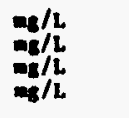 & $1.6 *$ & $\begin{array}{l}3.0 \\
0.001 \\
0.2 \\
0.02\end{array}$ & $\begin{array}{l}<0.005 \\
0.16 \\
0.07\end{array}$ & $\begin{array}{l}6.7 \\
<0.005 \\
0.36 \\
<0.01\end{array}$ & $\begin{array}{c}3.8 \\
<0.005 \\
<0.10 \\
0.02\end{array}$ & $\begin{array}{l}2.6 \\
<0.005 \\
<0.01 \\
<0.01\end{array}$ & $\begin{array}{l}1.2 \\
\vdots \\
-\end{array}$ & $\begin{array}{l}5.4 \\
=\end{array}$ & $\begin{array}{l}4.51 \\
0.03 \\
-\end{array}$ & $\begin{array}{c}4.8 \\
<0.005 \\
0.02 \\
0.03\end{array}$ & $\begin{array}{l}5.3 \\
= \\
-\end{array}$ & $\begin{array}{l}4.3 \\
= \\
=\end{array}$ \\
\hline & $\begin{array}{l}a / 2 \\
a / L \\
m / L\end{array}$ & 10 & $\begin{array}{l}<1.0 \\
0.12\end{array}$ & $\begin{array}{l}<1.0 \\
0.04 \\
<5\end{array}$ & $\begin{array}{l}11.0 \\
0.06 \\
10\end{array}$ & $\begin{array}{l}<1.0 \\
<5\end{array}$ & $\begin{array}{l}1.0 \\
<5\end{array}$ & $\overline{-}$ & $\overline{-}$ & 5.5 & $\begin{array}{l}<1.0 \\
65.4\end{array}$ & $\overline{-}$ & $\bar{z}$ \\
\hline $\begin{array}{l}\text { Grose Alphs } \\
\text { Grose Beto } \\
\text { Ra }\end{array}$ & $\begin{array}{l}p C i / L \\
p C i / L \\
p C i / L\end{array}$ & $\begin{array}{l}15 \\
5\end{array}$ & $\begin{array}{l}2.0 \\
17 \\
1.84\end{array}$ & $\begin{array}{l}0.7 \\
12 \\
0.79\end{array}$ & $\begin{array}{l}1.2 \\
1 i^{3} .3 \\
0.83\end{array}$ & $\begin{array}{l}5.9 \\
9.9\end{array}$ & $\begin{array}{l}3.0 \\
10.0 \\
0.78\end{array}$ & $\begin{array}{l}3.0 \\
3.4\end{array}$ & $\begin{array}{l}2.63 \\
4.06\end{array}$ & $\begin{array}{l}5.01 \\
4.01 \\
-\end{array}$ & $\bar{z}$ & $=$ & - \\
\hline $\begin{array}{l}\text { Doc } \\
\text { GC scan } \\
\text { Phenol: } \\
\text { Toc } \\
\text { TOA }\end{array}$ & $\begin{array}{l}-g / L \\
\mu g / L \\
-g / L \\
-g / L \\
m g / L\end{array}$ & & $\begin{array}{l}15.0 \\
<66.0 \\
0.034 \\
-\end{array}$ & $\begin{array}{l}6 \\
<40 \\
<0.002 \\
2 \\
0.079\end{array}$ & $\begin{array}{l}6 \\
<40 \\
<0.002 \\
9 \\
0.210\end{array}$ & $\begin{array}{l}5 \\
<40 \\
0.002 \\
28 \\
0.39\end{array}$ & $\begin{array}{l}>3.5 \\
<40^{\circ} \\
<0.002 \\
26.0 \\
0.031\end{array}$ & $\begin{array}{c}1 \\
\vec{j} \\
26 \\
<0.005\end{array}$ & $\begin{array}{l}2 \\
\overline{-} \\
5 \\
0.047\end{array}$ & $\begin{array}{l}5 \\
- \\
5 \\
0.031\end{array}$ & $\begin{array}{l}<5 \\
<40 \\
<0.002 \\
<5 \\
0.032\end{array}$ & $\begin{array}{l}<5 \\
\overline{-} \\
<5 \\
0.018\end{array}$ & $\begin{array}{l}<5 \\
\overline{-} \\
<5 \\
0.039\end{array}$ \\
\hline $\begin{array}{l}\text { Endrin } \\
\text { Lind ane } \\
\text { Methoxychlor } \\
\text { Tox aphene } \\
\text { 240 } \\
\text { 245TP. }\end{array}$ & $\begin{array}{l}\mu_{g} / L \\
\mu_{\mathbb{B}} / \mathrm{L} \\
\mu_{g} / \mathrm{L} \\
\mu_{g} / \mathrm{L} \\
\mu_{g} / \mathrm{L} \\
\mu_{\mathbb{B}} / L\end{array}$ & $\begin{array}{l}0.2 \\
4 \\
100 \\
5 \\
100 \\
10\end{array}$ & $\begin{array}{l}<0.003 \\
<0.003 \\
<0.015 \\
<0.5 \\
<8.93 \\
<0.007\end{array}$ & $\begin{array}{l}<0.54 \\
<0.11 \\
<2.5 \\
<6.0 \\
<0.31 \\
<0.14\end{array}$ & $\begin{array}{l}<0.04 \\
<1 \\
<20 \\
<1 \\
<20 \\
<2\end{array}$ & $\begin{array}{l}<0.04 \\
<1 \\
<20 \\
<1 \\
<20 \\
2\end{array}$ & $\begin{array}{l}<0.04 \\
<1 \\
<20 \\
<1 \\
<20 \\
<2\end{array}$ & $\begin{array}{l}\overline{-} \\
\bar{z} \\
=\end{array}$ & $\begin{array}{l}\overline{-} \\
\vdots \\
5\end{array}$ & $\begin{array}{l}5 \\
\vdots \\
\vdots\end{array}$ & $\begin{array}{l}<0.04 \\
<1 \\
<20 \\
<1 \\
<20 \\
<2\end{array}$ & $\begin{array}{l}= \\
= \\
=\end{array}$ & $\begin{array}{l}= \\
= \\
=\end{array}$ \\
\hline
\end{tabular}


AppenoIx $\mathrm{D}$ Contd

Roselts of Monitoring Woll Malyses for M-Area Settling Basin

\begin{tabular}{|c|c|c|c|}
\hline \multirow[t]{2}{*}{$\begin{array}{l}\text { nse a and on } \\
\text { Dombredient }\end{array}$} & Plent Coordinates: & 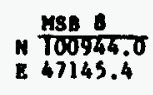 & $\begin{array}{l}\text { MSB } 8 A \\
\frac{100796.20}{47302.80}\end{array}$ \\
\hline & Gauin Blevation ( $\mathrm{ft}$ ): & 339,4 & 343.72 \\
\hline
\end{tabular}

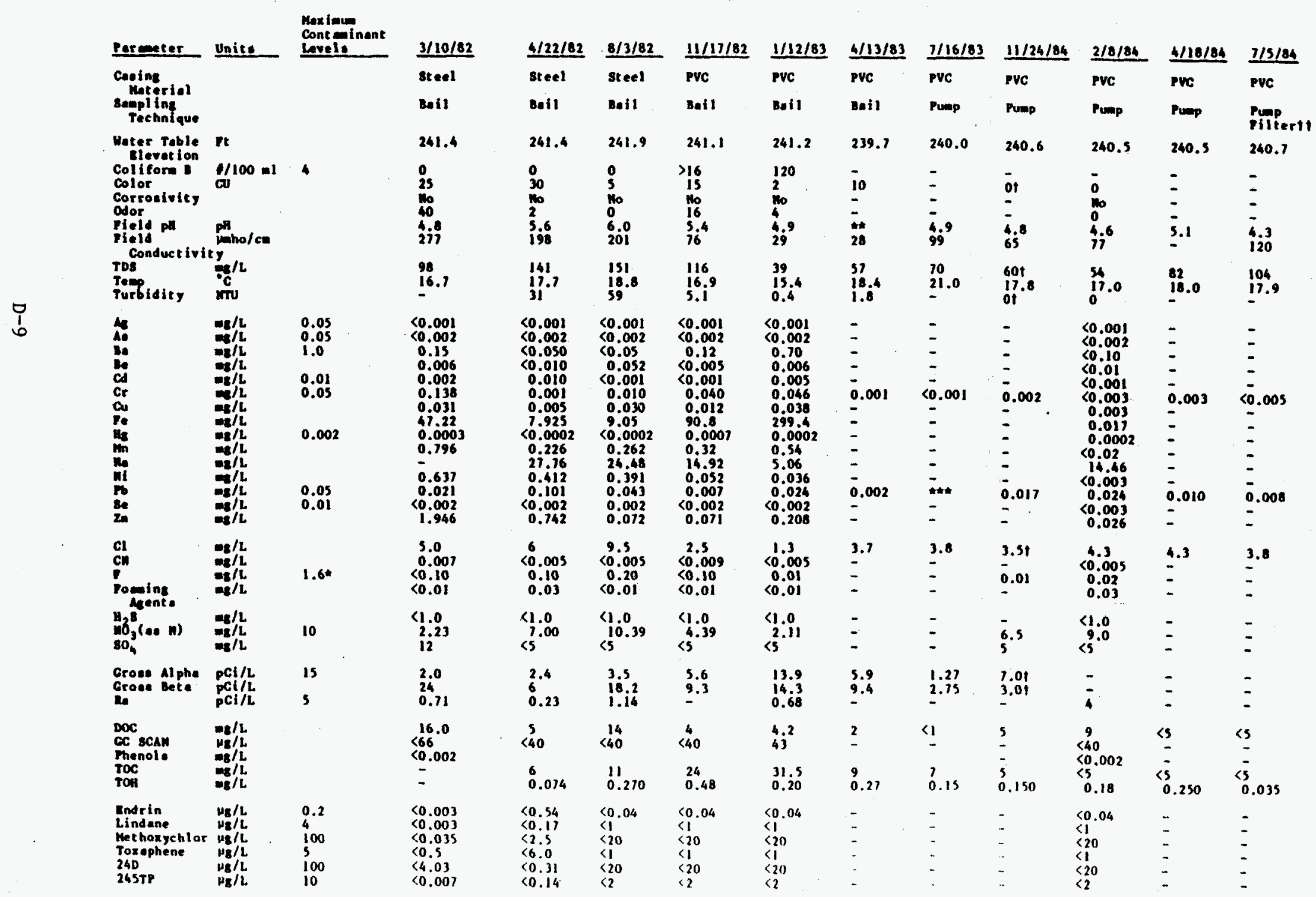


Footnotes to the monitoring well analyses Tables.

* MCL at 21.5 to $26.2^{\circ}$.C.

** Not reported (Field measurement not confirmed by laboratory measurement).

*** Not reported (Field blank high).

†nvirodyne analysis of these parameters started 4th quarter, 1983 (previously determined by SRL-Health Protection).

t† Filtered thru $0.45 \mu \mathrm{m}$ membrane.

t†† Special Resample, (Samples taken first quarter of 1984).

I Special sample analyzed by ICP and IC at SRL.

11 Assumed reporting error; changed $9.4 \mathrm{mg} / \mathrm{L}$ to $94 \mathrm{mg} / \mathrm{L}$. 


\section{APPENDIX E. SAMPLING AND ANALYTICAL PROTOCOLS FOR GROUNDWATER}

QUALITY ANALYSES

All of the analyses reported in Appendices B, C, and D were collected by using a sampling protocol, but these differed over time and depending on the purpose of the sampling.

Appendix E-1 contains a sampling protocol developed in April 1983 and directed primarily toward obtaining samples for analysis of volatile organics. Thus it was used for the $1983 \mathrm{samples}$ which were analyzed for degreaser solvents reported in Appendix B. It was also used, however, for the 1983 samples analyzed for metals, major cationic and anionic constituents, radioactivity, and certain other organic constituents reported in Appendix $C$. It should be noted that the protocol does not contain a requirement for filtering the sample, which can greatly affect the results for metal concentrations.

Appendix E-2 contains the sampling protocol formally issued in October 1984; however, it was the protocol used in collecting the samples April to July 1984, which are reported in Appendix C. This protocol is broadly based and addresses the collection of samples for any reason. It contains a procedure for filtering the sample for metal analysis. The full protocol contains a section on analytical procedure for samples analyzed at SRP. This is not included because all of the results given in Appendix $C$ are from a contractor laboratory which maintains its own protocol and follows Environmental Protection Agency procedures.

Appendix E-3 contains the sampling protocol for the analytical results reported in Appendix $D$. 
APPENDIX E-1

\section{M-AREA GROUNDWATER SAMPLING PROCEDURES}

\section{PURPOSE}

The technique for collecting groundwater samples for chemical analysis is critically important especially in the identification of volatile organic compounds. The primary concerns in collecting samples are: 1) to obtain representative samples by evacuating stagnant water from the well casing prior to obtaining the sample, and 2 ) to assure that contamination of the sample does not occur as part of the sampling technique. The purpose of this procedure is to provide complete instructions for the sampling of monitoring wells as part of the M-Area Groundwater Program.

\section{INTRODUCTION}

Newly installed monitoring wells are developed by the addition of large volumes of clean water and pumping with compressed air until the water being produced by the well is clear and free of sediments. After initial development approximately 1000 gallons of water is removed from the well by use of a submersible pump. Since volatile organics are a major concern, pumping with air is NOT used to remove this volume as this method would strip the organic compounds from the water during pumping.

Once the development of the well is completed, water samples for laboratory analysis can be collected. The South Carolina DHEC recommends four to six well-volumes be evacuated from a monitoring well prior to obtaining a sample for analysis. The sample should be collected immediately after evacuation. Because of the relative large diameter (4") of the monitoring wells and the depth of the wells (up to $300^{\prime}$ or more), the evacuation of the minimum 4 well volumes is best accomplished with a submersible pump. Therefore, in order to prevent cross contamination and to facilitate the sampling operation, dedicated pumps are installed in each well to be sampled. The procedures to be followed in the collection of M-akea groundwater samples as detailed in this document are in agreement with DPSOL 271-1-323, well Water Sampling Procedure for Nonradioactive Parameters.

\section{SAFETY}

1) Personnel will wear safety glasses and rubber gloves when performing all phases of the sampling and handling procedures.

2) Hou'sekeeping must be maintained at all sites.

3) Any unsafe conditions or hazards should be reported to supervision immediately.

4) When pumping, all equipment must be properly grounded. 
1) Obtain copies of groundwater sample data collection sheets from supervision. Attachment 1 .

2) Obtain sample vials, field blanks, and coolers from 320-M laboratory. Obtain frozen ice packs and place in separate coolers for transport to the field.

3) Hook generator to vehicle. All pumps are 115-volt.

4) Proceed to the monitoring well with equipment. Wear safety glasses and rubber gloves for your personal protection at each site. Gloves also protect the sample since personal contact with equipment can introduce chemical contaminants.

5) Position generator. near well to be sampled, but on opposite side of well discharge line.

6) Using an electric water level indicator, measure the depth to water (DTW) from the top of the well casing by

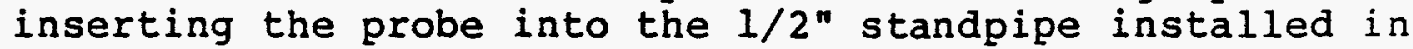
each well for this purpose. Record the DTw in Column $C$ of the data sheet.

7) Determine the water column in the well by subtracting the DTW (Column C) from the total depth of the well (Column B). Record in Column D.

8) Determine the amount (gallons) of water to be pumped from the well in order to evacuate 4 well volumes by multiplying the water column (Column D) by 2.6. Record in Column E.

9) Connect flow meter to discharge line.

10) Ensure pump switch is OFF and then connect pump cord to power source. [Note: More than one well at a sample site may be pumped at the same timel. Ensure system is grounded.

11) Check all valves, gages, etc. The discharge line valve must be open.

12) Record the flow meter reading in Column $F$.

13) Start generator.

14) Turn pump switch to $O N$ and remove four well volumes as determined in Column $\mathrm{E}$.

15) After removing 4 well volumes fill sample vials from the 1/4" sample nipple located on the discharge line from the pump. Since the primary concern is volatile organics, the water sample should have minimum contact with air and should not splash into the receiving container. The sample vial must be filled to overflowing before capping to purge all air from the vial. [Note: Handle sample vials only with clean gloves, not ones used to handle pump equipment].

16) After collecting sample turn pump switch to ofF and record the ending meter reading in Column $G$.

17) Note the exact amount of water removed in Column $H$ by subtracting Column G from Column F.

18) Label sample vials with well number and date collected. 
19) Record the collection date in Column I and sign Column J.

20) Ensure there is no leak in the sample vial and place sample in cooler.

Note: For wells that will not provide 4 well volumes, i.e.. the total column of water is evacuated while pumping, allow the well to fully recover (measure water level again). When recovery is complete, throttle pump by partially closing discharge valve and proceed with sampling. If possible, more than one volume of water should be evacuated. Samples should be collected immediately after well recovery.

21) When sampling is complete at each site, unplug pump/pumps from power source.

22) Perform housekeeping around site, load samples and equipment, and proceed to next site.

23) Repeat steps 5 through 22 for each well being sampled.

24) At end of day return all samples collected to 320-M laboratory.

Approved

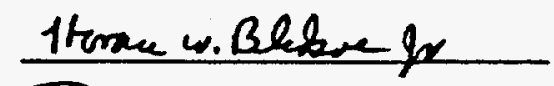

Date $4 / 22 / \varepsilon 3$

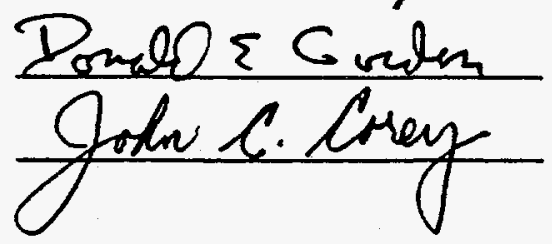

$\mathrm{HB}: \mathrm{CE}$ 
M-AREA GROUNDWATER SAMPLING PROGRAM SAMPLE COLLECTION SHEET

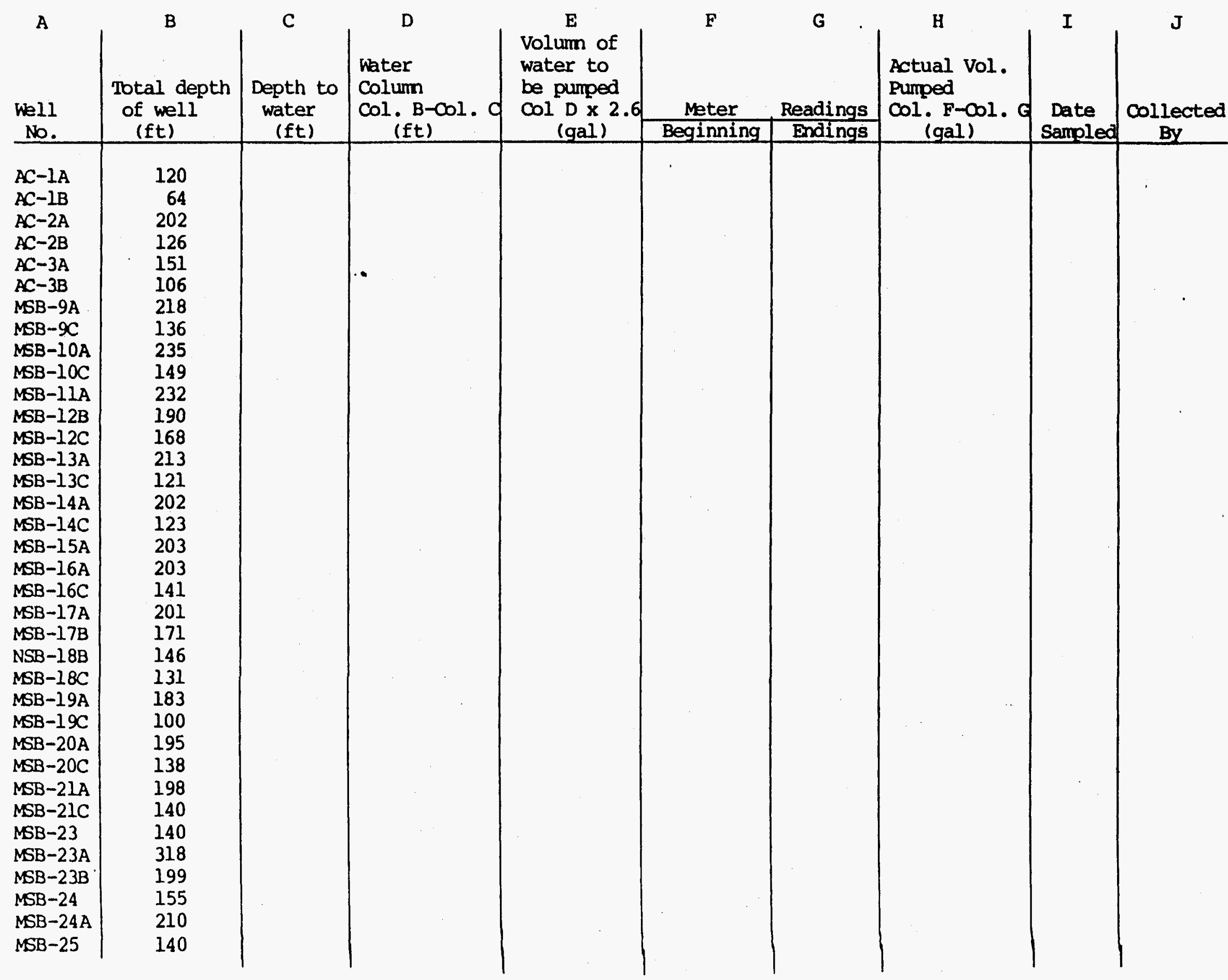


M-AREA GROUNDWATER SAMPLING PROGRAM

SAMPLE COLIECTION SHEET

\begin{tabular}{|c|c|c|c|c|c|c|c|c|c|}
\hline $\begin{array}{l}\text { Well } \\
\text { No. }\end{array}$ & $\begin{array}{c}\text { B } \\
\text { Total depth } \\
\text { of well } \\
\text { (ft) }\end{array}$ & $\begin{array}{l}\text { C } \\
\text { Depth to } \\
\text { water } \\
\text { (ft) }\end{array}$ & 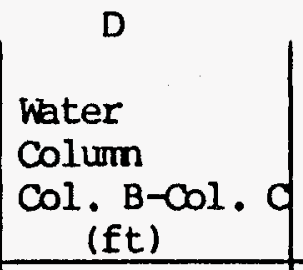 & $\begin{array}{l}\quad E \\
\text { Volum of } \\
\text { water to } \\
\text { be pumped } \\
\text { Col D x 2.6 } \\
\text { (gal) }\end{array}$ & $\begin{array}{c}\text { F } \\
\text { Meter } \\
\text { Beginning }\end{array}$ & $\begin{array}{c}\text { G } \\
\text { Readings } \\
\text { Endings }\end{array}$ & $\begin{array}{c}\text { H } \\
\text { Actual Vol. } \\
\text { Pumped } \\
\text { Col. F-Cl. G } \\
\text { (gal) }\end{array}$ & $\begin{array}{c}\text { I } \\
\text { Date } \\
\text { Sampled } \\
\end{array}$ & $\begin{array}{c}\mathrm{J} \\
\substack{\text { By } \\
\text { By }} \\
\end{array}$ \\
\hline $\begin{array}{l}M S B-25 A \\
M S B-26 \\
M S B-26 A \\
M S B-27 \\
M S B-27 A \\
M S B-28 \\
M S B-28 A \\
M S B-30 A \\
M S B-30 C \\
M S B-31 A \\
M S B-31 B \\
M S B-31 C \\
M S B-32 \\
M S B-33\end{array}$ & $\begin{array}{l}205 \\
119 \\
180 \\
130 \\
170 \\
122 \\
200 \\
316 \\
135\end{array}$ & & . & & & & & & $i$ \\
\hline
\end{tabular}


Issued: $\quad 10 / 1 / 84$

Revision: 0

\author{
APPENDIX E-2

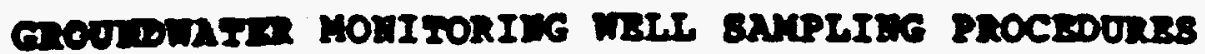

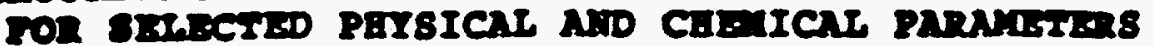 \\ (PUTPED BAMPLES)
}

\begin{abstract}
A. PURPOSB
The technique for collecting groundwater samples for chemical analysis is critically important. The primary concern in collecting samples is to protect sample integrity and minimize error. The procedures described here are designed: 1) to obtain representative samples by evacuating nonequilibrated water from the well casing or sample tap prior to obtaining the sample, 2) to assure that contamination of the sample does not occur as part of the sampling technique, 3) to provide sample preservation, and 4) to follow chain of custody requirements and proper documentation specifications. In addition, these sampling procedures are designed to comply with applicable regulations and guidelines (Ref. 1-5), and to provide consistency with Savannah River plant sitewide procedures (DPSOP 254. Hydrogeologic Data Collection). These procedures have been written to minimize loss of volatile organic compounds when sampling wells with effervescent water. Bladder pumps should be used for these wells while turbine pumps can be used for all others.
\end{abstract}

\title{
B. INTRODOCTION
}

Water samples are routinely collected for analysis of volatile organic compounds (VOC), Eull-scan priority pollutants (FSPP), and other chemical parameters from monitoring wells.

The proper sampling procedures for these collections are described herein and are organized as follows:

1) Safety

2) Chain of Custody

3) General Considerations

4) Collection Methods and Field Measurements

5) Analyte Specific Requirements

5.1) volatile organic compounds

5.2) full scan priority pollutants

5.3) other chemical parameters

6) Shipping and Delivery of Samples

The personnel responsible for sampling the groundwater monitoring wells should read carefully the pertinent sections and meticulously follow the protocol. A copy of these field procedures should be available at the sampling location for review. Supervision (or project manager) is responsible for requesting the collection of groundwater samples and for maintaining auditable files on sample 
collection and custody records. The sampler will provide a sumary report each week of samples collected during the week, and a projected schedule for the following week. A bound field notebook will be maintained which documents daily instrument calibration, instrument service, wells sampled and field observations. Each page of the notebook will be dated and signed by the sampler.

\section{PROCEDURES}

\section{Safety}

1. Personnel will wear goggles and disposable gloves when performing all phases of the sampling and handling procedures.

2) Housekeeping must be maintained at all sites.

3) Any unsafe conditions or hazards should be reported to supervision immediately.

4) When pumping monitoring wells, all equipment (e.g., portable generators and pumps) must be properly grounded.

\section{Chain of Custody}

The primary objective of these procedures is to create an accurate written record that can be used to document and trace the possession of a sample from the moment of its collection through its analysis. The resulting Information aids in scientific date interpretation and is required if the sample is used as legal evidence. In chain of custody procedures, each custodian must sign and date each transfer. The following description of "bulk transfer" procedures conforms to that of the EPA Office of Enforcement. 6

Samples must be accompanied by the Custody Transfer Record (similar to Attachment (1) which includes the sampler's signature and initials, sample identification, date, the "return to" address (e.g., "name of supervision". "auditable file location"), and the relevant transfer and shipping history of the sample containers. Attachment 1 was designed for ease of use and to facilitate computer entry and tracking. The sampler should fill in each appropriate space in ball-point pen. Subsequent transfers are recorded by signature and initials. Shipping receipts along with a copy of on-site custody transfer sheets shall be maintained in a specified location with copies sent to SRL and supervision in M Area. Outside laboratories should return a signed copy of the custody transfer record along with a summary of their internal chain of custody to M-Area supervision. Any unusual incidents $(\mathrm{e} . \mathrm{g}$. , broken or partially full bottles, or missing information) should be noted and reported to supervision immediately. If only a portion of the sample vial are transffered, the item numbers or appropriate information should be noted. Additionaliy, a form OSR-14-31 (Analysis Request - SRP) must be submitted to on-site labs with the samples. 


\section{General Coneiderations}

\subsection{Regulated Areas}

- Personnel entering Regulated Areas must familiarize themselves and comply with all safety rules and protective clothing procedures.

- Bealth Protection area superviaion must be notified prior to sampling wells inside regulated areas.

- When moving from one well site to another inside regulated areas, the technician will remove shoe covers when entering vehicle and put on shoe covers prior to dismounting from vehicle.

[NOTE: Shoe covers and any other Regulated Area protective equipment will be disposed of in approved receptacles.]

- Vehicle tires must be checked prior to leaving a Regulated Area. The vehicle must not leave the area until Health Protection (Area Survey) gives permission.

3.2 Equipment Required - all sources of equipment and individual items are to be approved by supervision tor the project manager).

- Generator, gasoline can control box (used when pumping with portable generator).

- Bladder pump controller and compressed gas (air or nitrogen) source (used when pumping deep wells which effervesce).

- Measuring tape, steel $200 \mathrm{ft}$ and/or electric water level indicator (calibrated within 6 months).

- Tape, one roll, filament

- Field data Sheets and Chain of custody Sheets

- Pens (2), water resistant ink and ball point

- Thyac (if needed)

- Distilled water to rinse equipment

- Aluminum foil (to protect water level tape from contact with ground)

- Flow meter 


\section{- Laboratory grade thermometer}

- Eand air/vacuum pump

$0.45 \mathrm{~m}$ filter and holder

- Properly prepared bottles (See Attachment 2)

- Coolers: received from laboratory and containing sample bottles and frozen ice packs. [NOTE: Sample blanks should be treated as samples. They are shipped on ice and should be kept cold after inspection. If a vial is broken, the remainder of blanks in the same canister should be discarded. Coolers should be clean.] Some of the sample containers submitted to on-site labs are kept in stores. Contact lab personnel for caption and bin numbers.

- Water quality monitors calibration standards, rinse bottle, beakers and laboratory wipes. [NOTE: Normally, separate $\mathrm{pH}$ and conductivity meters will be used. These should be kept in plastic bags with dessicant and calibrated each day, and at each site as described in Attachment 3. Calibration records will be kept in the bound field notebook. I

- Preservative (See Attachment $\$ 2$ )

- Rubber gloves, leather gloves, safety glasses, disposablee plastic gloves

- Regulated Area: Follow posted requirements

- A copy of the field procedures

- Clip board

- Correct bound field notebook.

\section{Collection of Methods and Field Measurements}

a) Obtain copies of the Custody Transfer sheet (Attachment 1 or similar) and the field data sheet from supervision (or the project manager). Normally, an OSR 24-C241A (Water Sample Collection Field Data Form) will be used (Attachment 3 ). References in this procedure pertain to these forms. Also, obtain a list of wells (sampling order and location), specific samples needed and the destination laboratory location from supervision.

b) Obtain sample vials, field blanks, and coolers from designated area. Obtain frozen ice packs and place in coolers for transport to the field. 
c) Obtain all other equipment listed in Section C.

d) All pumps are 115 single phase 120 volt AC except the pressure operated bladder pumps in the Tuscaloosa Wells.

e) Proceed to the monitoring well with equipment. Wear safety glasses and rubber gloves for your personal protection at each site. Gloves also protect the sample since personal contact with equipment can introduce contaminants. Wear leather gloves when working with machinery or sharp objects, rubber gloves when working with strong acids or bases, and disposable gloves for other sample manipulations.

f) Position generator or compressed gas source and control box near well to be sampled, but on side opposite to discharge line of pump.

g) Fill in date on field form. Sign, date and initial top of custody transfer record.

h) Fill in well number, date and duplicate ID (if required) on both field forms and custody transfer record. Record time on field forms. Record will number, date and duplicate ID (if required), and time in bound field notebook.

i) Fill in total well depth on the field form (Column A). Obtain well depth information from supervision (or project manager).

j) Using an electronic water level indicator or steel measuring tape (DPSOP 254), measure the depth to the water (DTW) from the top of the well casing. The tape or probe should be inserted into the 1/2" standpipe installed in each well. Record the DTW on the field forms (Column B). Place aluminum foil on ground to protect tape. Wash tape before sampling next well.

k) Determine the water column in the well by: DTW (Column B) from the total well depth (Column A) and record the result on the field form (Column C).

- for turbine pumps - subcontracting the DTW (Column B) from the total well depth (Column A). Record the result on the field form (Column C).

- for bladder pumps - subcontracting the depth of the well packer (provided by supervision) from the result on the field form (Column $C$ ).

1) Using Attachment 5 determine the volume to be pumped from the well in order to evacuate 4 well volumes prior to sampling. If the well is not $4^{n}$ diameter, or if the water 

using the formulas provided.

Record the volume to be pumped on the field form in the column provided.

m) Connect flow meter to discharge line.

n) Ensure pump switch is OFF and then connect pump cord to power source. Ensure system is grounded. Only one well should be pumped at any time. For bladder pumps, inflate packer and prepare system to pump.

o) Check all valves, gages, etc. The discharge line valve must be open.

p) Record the initial flow meter reading on the field form in the column provided.

q) Start generator for turbine pumps or pressurize bladder pump system.

r) Turn pump switch on and remove 4 well volumes of water. Note any obvious water characteristics in the field notebook. If a note is entered in the notebook, an " " should be placed in the contaminant column of the field form. Examples of notable characteristics are: color, odor, rotten egg smell, floc (algae, bacteria, etc), oil, sand, other solids, bubbles.

s) Calibrate pH meter while well is pumping. After removing 4 well volumes, open sample nipple and run for 2 minutes; rinse the measuring probes and the sample vessel with this water to equilibrate. Measure air and water temperature using laboratory grade thermometer. Then measure the $\mathrm{pH}$ and conductivity according to the directions in attachment 13. Record these measurements on the field form. Perform any other field measurements (e.g., alkalinity) which were requested by supervision (or the project manager).

t) Fill sample vials and preserve as required according to Section $E$ and Attachment 2 . [NOTE: When sampling for volatile compounds, fill vials carefully without agitation or splashing to avoid loss of analyte. Leave no air space at the top. Handle sample vials only with clean plastic gloves, not ones used to handle pump equipment. Filter samples for metals through a 0.45 um filter using a nonmetallic filter holder and hand air pump before adding acid. 1 
u) After collecting samples, turn pump switch off and record ending meter reading on field forms. Measure the water level, record this reading and the time on the well recovery data form. Calculate the volume pumped and record on field form. While completing steps $v$ through $y$. continue to periodically measure the DTW and time and record on the field form (until well recovery).

v) Label sample vials with well number and date collected.

w) Check sample vials and place in cooler. Fill in Custody Transfer Record.

x) Rinse meter probes, sample cup and filter holder with distilled water. Turn off power and prepare for transit. [NOTE: For wells that will not provide 4 well volumes, i.e., the total column of water is evacuated while pumping, allow the well to fully recover (measure water level again). When recovery is complete, throttle pump by partially closing discharge valve and proceed with sampling. Samples should be collected immediately after well recovery. Also, record this on the field form and in the field notebook. J

[NOTE: For wells which are continuously pumped, purge sampling port for 2 -minutes and proceed with sampling. $]$

y) Sample next well in cluster (repeating steps $h-x$ )

2) Unplug electric pum/pumps from power source.

aa) Perform housekeeping around site, load samples and equipment, and proceed to next site.

bb) At the end of the day, return all samples to 704-U (or location designated by supervision or the project manager for shipment/distribution. Transfer samples to the shipping department and record. [NOTE: Three photocopies of the field data forms, custody transfer sheets and pertinent pages of the field book should be made. The originals will be maintained in the QA/Data/Equipment file (in 704-U or other designated location) and the copies will be distributed to (1) M-Area Supervision, (2) SRL and (3) sampler. I

\section{Analyte Specific Requirements}

5.1) Volatile Organic Compounds

Samples should be collected in $45 \mathrm{ml}$ vial with a teflon lined silicone septum. Vial should be gently filled until water flows over the top and then tightly capped. Samples should 
be etored cold (about $4^{\circ}$ C) unt 12 analysis. Duplicate vials w11 be filled for each well sample.

\section{2) Full-scan Priority Pollutants}

When a full scan of analyses for priority pollutants is required, the following bottles should be set out for each well sample:

2 vials - volatile organics

1 vial - GC scan

1 platic container - metals (filtered)

1 amber glass jar - phenols

1 amber glass jar - TOB

1 glass jar - coliform

1 plastic bottle - radionuclides

1 plastic bottle - sulfide

1 plastic bottle - $\mathrm{SO}_{4}, \mathrm{P}-$, etc.

1 glass jar - non-volatile organics

1 glass jar - odor

Several constituents are required to be preserved with particular chemicals. Many of these chemicals are caustic and should be treated with caution. Plastic gloves (not those used for sampling) should be used. The container description and necessary preservatives for each analyte are listed in Attachment $\$ 2$.

5.3) Other Chemical Parameters

Analysis of groundwater samples for a partial list of analytes discussed above or for other chemical parameters may be reguired. Appropriate containers/instruments/

instructions will be provided for each round of samples.

Examples of other typical analytes include alkalinity (field), sodium, calcium, magnesium, aluminum and potassium. These major constituents in groundwater are often required for various:water chemistry purposes.

\section{Shipping and Delivery of Samples}

Many of the chemical analyses for groundwater constituents must be carried out within two weeks (Attachment $\$ 2$ ). Therefore, supervision (or the project manager) should make arrangements for the immediate transfer of samples to the appropriate laboratories. Supervision is responsible for designating a shipping coordinator who will receive and distribute the samples and completed paperwork. Samples shipped to offsite laboratories should be packed with fresh ice packs and shipped by air in ice chests within 2 days. Shipping information should be recorded on the custody transfer record. Do not ship samples offsite on Fridays without prior arrangements. 


\section{Destuda:}

1) 0. 5. Enviromental Protection Agency. Bandbook for Analytical Quality Control in Mater and Wastewater Laboratories. EPA-600/4-79-019 (1979).

2) U. S. Department of the Interior. National Handbook of Recommended Methods for Mater-Data Acquisition. Office of Water Data Coordination/Geological Survey (1977).

3) 0. S. Environmental Protection Agency. Environmental Protection Agency National Interim Primary Drinking Water Regulations. 40 CPR 141 (1982).

4) 0. S. Environmental Protection Agency. Methods for Chemical Analysis of Nater and Wastes. EPA-600/4-79-020 (1979).

5) Lee, G. F. and R. A. Jones. Guidelines for Sampling Groundwater. JWPCE SS: 92-96 (1983).

6) United States Environmental Protection Agency. NPDES Compliance Sampling Manual. Office of Water enforcement (June 1977). 
Iminas OSR 24-C253

\begin{tabular}{c}
\hline CHAN OF EUSTOOY RECORO \\
WATER SAMPLES \\
OUIPOUTLSA?
\end{tabular}

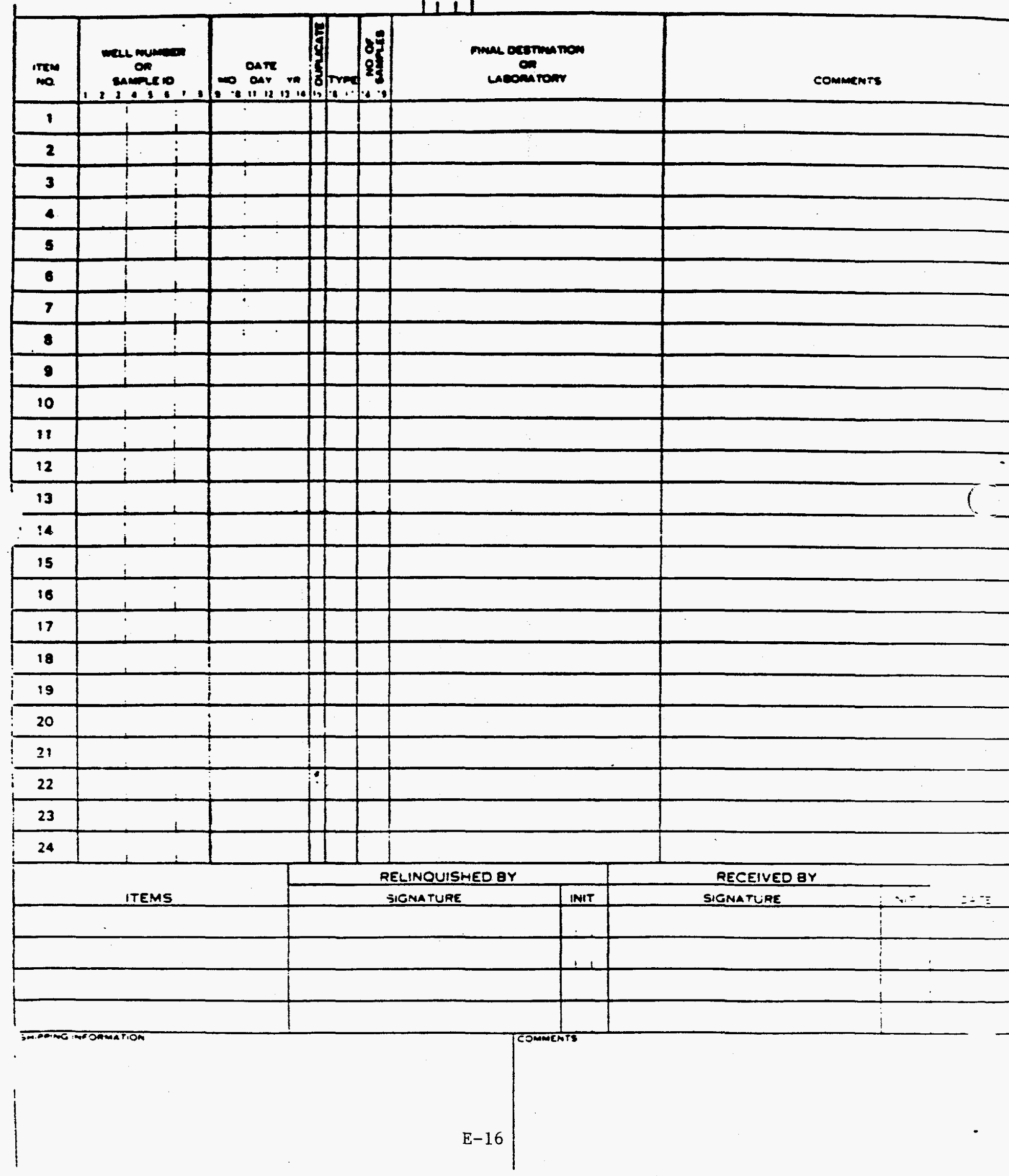




\section{atracmerse 12}

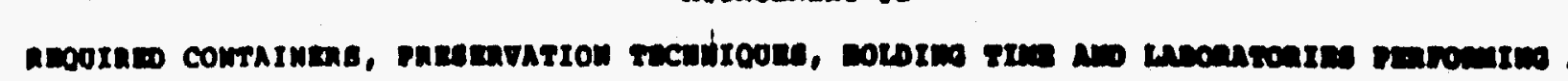

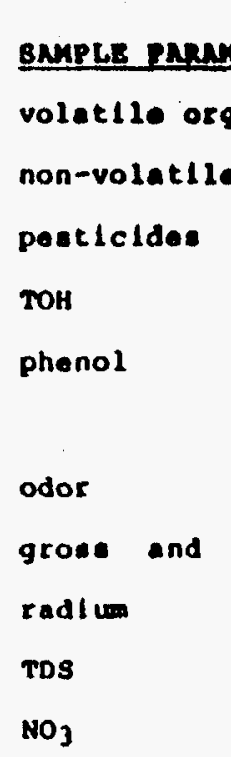

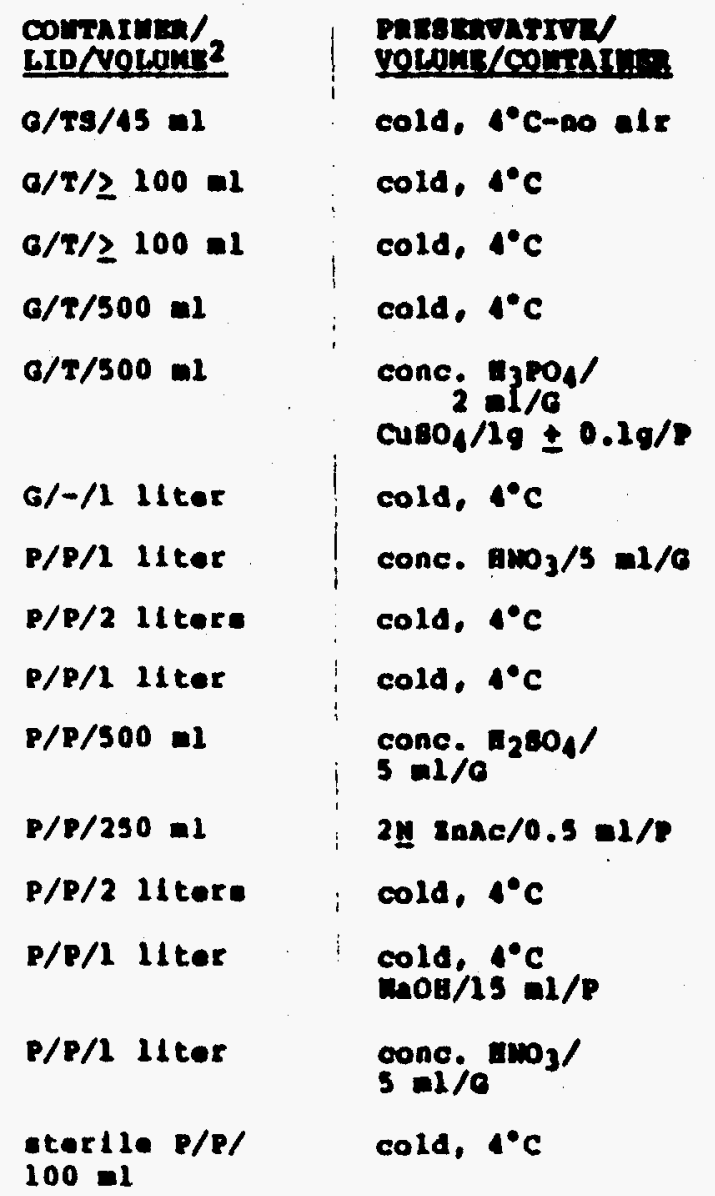

notorn:

XII!

14 aye

14. daye

7 daye

14 anye

20. daye

- - -

6 montbe

- mopthe

7 daya

20 daye

7 anyo

20 eriyo

14 anye

6 monebe

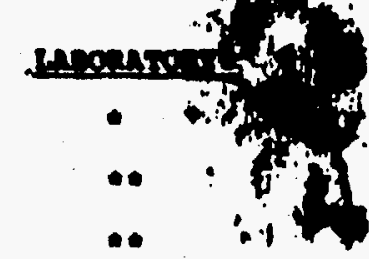

$\bullet$

$\bullet$

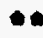

aulfide

$\mathrm{SO}_{4}$

cyanlde

metale

total collform

1 day 


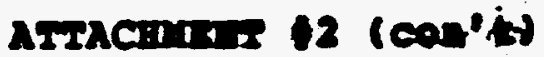

1) Each vial label will contain the well group ID, date, duplicate (if applicable), preservative, and parameter.

2) The laboratory or sampler should prepare bottles, caps and preservatives (except coliform - this sterile container is purchased from stores). $P$ = polyethylene, $G=$ glass, $T=$ teflon liner, TS = teflon lined silicone septum.

3) * 320-M or offplant laboratory (non-radioactive samples)

* - offplant laboratory

* = 735-A or offplant laboratory

*** = 772-D or offplant laboratory 


\section{ATTACHMENT 3 \\ INSTRUMENT CALIBRATION PROCEDURES}

\section{A. ALL MEIERS}

The electronics of all meters used in the field should be kept in a plastic bag with dessicant. Experience in the southeastern region shows that this is a necessary step to avoid problems with humidity.

\section{B. COQNDEUCII IYIIY MEIER}

1) Daily Calibration - Place a small amount of previously prepared $0.01 \mathrm{~N} \mathrm{KCl}$ solution in a beaker (solution is prepared by dissolving $745.6 \mathrm{mg}$ of anhydrous $\mathrm{KCl}$ in deionized water).

Measure the temperature of this solution with a laboratory grade thermometer. Record in bound field notebook. Place conductivity probe in solution, turn temperature compensation knob to the measured temperature, and turn selector knob to the 0-1999 scale. Adjust the reading to 1413 umhos/cm using the cell constant knob. Record the meter was successfully calibrated to 1413 umhos/cm in the field notebook. Rinse electrode with deionized water and dry with a laboratory wipe.

2) At Each Site - No recalibration is required. Measure the temperature of the sample solution. Place the conductivity probe in the sample, turn the temperature compensation knob to the measured temperature, and place the selector knob in either the 0-199.9, $0=1999$, or $0-19999$ position. Use the lowest (most accurate) position which results in an "on-scale" reading. If a reading is "off-scale", the display will read ' 1 " in the far left digit position.

NOTE: Three zeros must be added to the values read on the $0-19,999$ scale (eg., $12.88=12880$ umhos/cm).

3) Weekly Maintenance \& Troubleshooting - Each week, the cover of the probe should be removed, and the fVC body and steel rings should be cleaned using alcohol and a cotton swab. After cleaning, the probe should be thoroughly rinsed and oried carefully with a laboratory wipe. Check the dessicant and replace if necessary. Replace 9 volt battery when the 'low battery signal is displayed.

The electrode is made of FVC and has a limited resistance to temperature extremes. In particular, it should be noted that tr.e 4 steel rings, which combine to form 2 electrode pairs, are imbedded in Fuc. Frolonged exposure to high heat can open the joint permitting fluid underneath and brealing the contact. A damaged electrode can be identified as follows: in air (with switch in the $0-199.9$ position, the display should read 0.0 ' ireadings of ' $0.1^{\prime}$ to $' 0.2^{\prime}$ ' are still acceptable). Higher readings (eg., ' $10^{\prime}$ ) are a clear sign of a ruined electrode. Other erratic behavior should be corrected based on the manual or by calling Cole-Farmer for technical assisstance at $1-800-325-4.40$. (model number $1481-50$ ) 


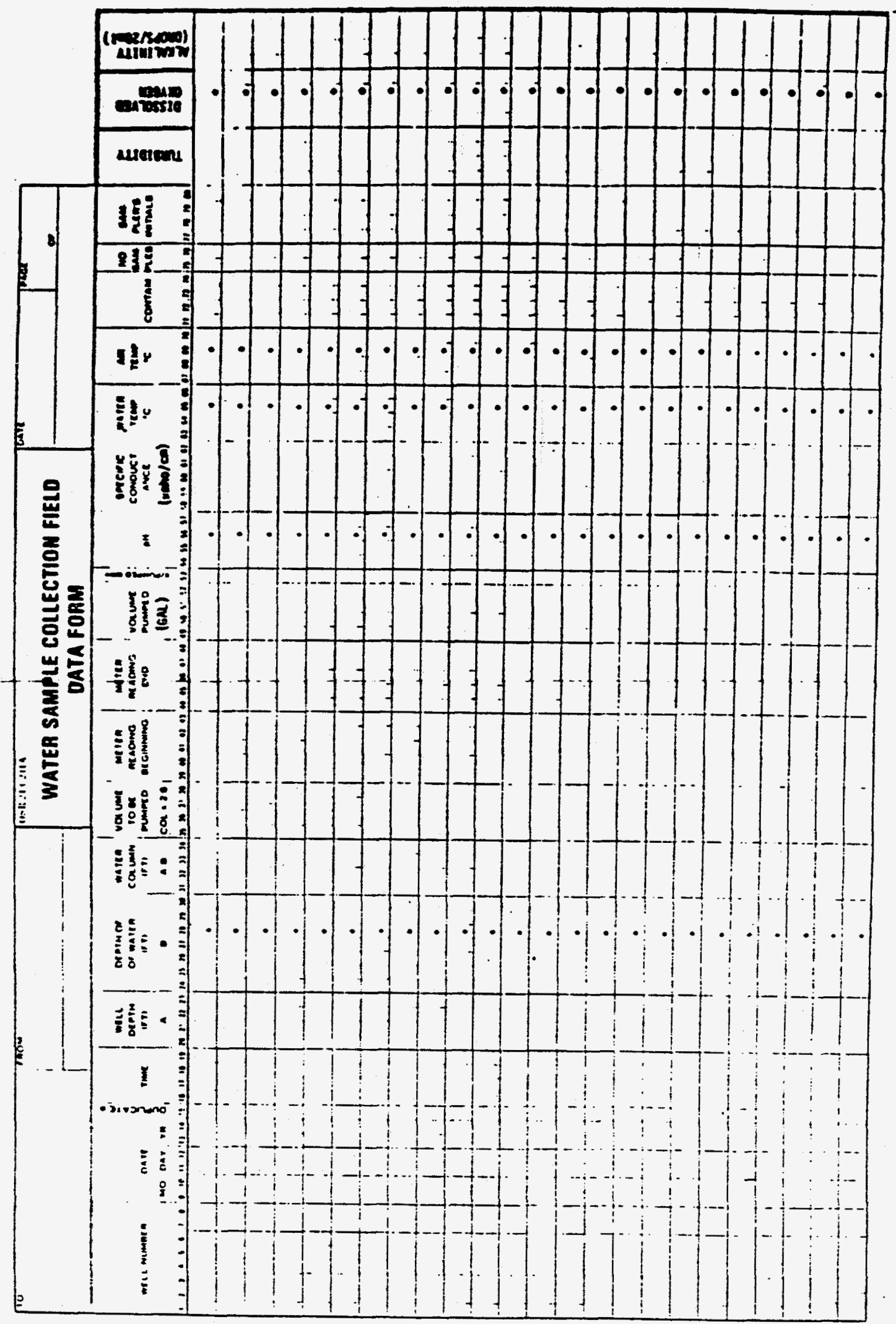




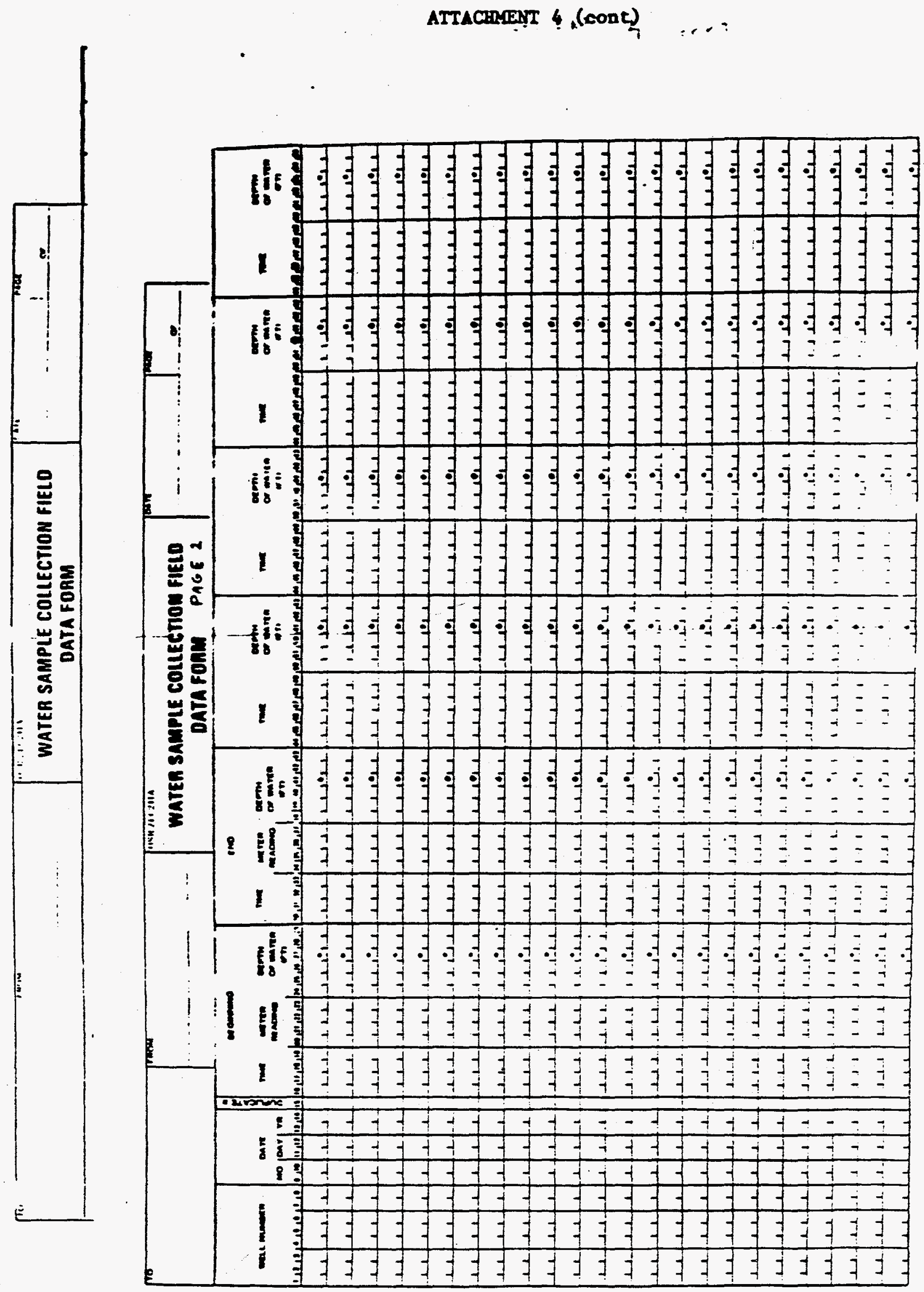




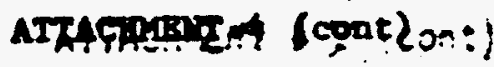

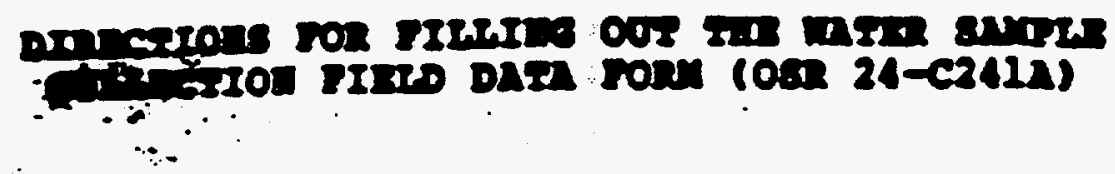

\section{wers bithe}

Colung 1-8 are the well mane as in the Hell F1le Index or preasigned name of surface mater collectlon site. Colums 1-3 are an alphe fleld. left justifled. Coluns i-6 are a numeric fleld. Ilght justified. Columa 7-8 are a alpha-punerlc field, left justifiad. (exaples MSB 11A)

\section{Date}

8ample collection date. (exanples 090783)

\section{Dorirente}

Hormally a blank fleld. Thls can be an alpha or nueric character used to distinguisb samples collected at a site durlog a eingle day. (example a b)

\section{TIns}

Military time. (examples: 7:45 AM 18 0745, 1:50 PM is 1350)

\section{WETI DEPIE}

The total depth of the well frou the top of the casing. This number is obtained from the driller's log of the well.

\section{DEPTE OF UATR}

The distance from the top of the casing to the water surface is the well prior to pumping recorded as decimal feet.

\section{MATER COLUD}

See instructions in procedures.

\section{VOLUYA TO BE POAPED}

See instructions in procedures. 


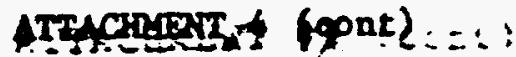

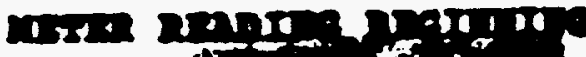

The

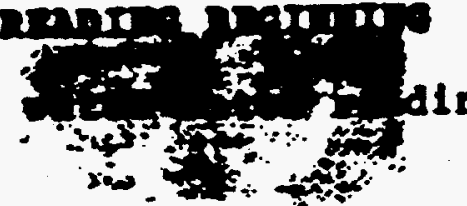

before pupling the well.

sod 50

Mxt Rering ID

The water meter reading after punping the vell.

voron runpo

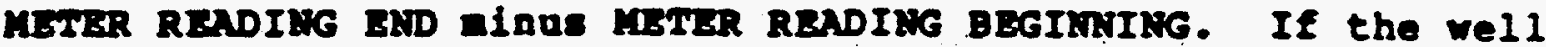
we eampled with no puping, enter sero $(0)$. Enter -1 if well 1. being continuously purped.

I/PUT: DRI

Enter $x$ if the well was pumped dry.

p.

Enter pE measurement of water taken after pumping is completed.

\section{SPECIFIC COIDUCTRIC.}

Specific conductance measurement.

\section{WhIt 2yap ${ }^{\circ} \mathrm{C}$}

Water temperature measured at sampling point.

\author{
AIR ITIP ${ }^{\bullet} \mathrm{C}$ \\ Air temperature measured at time of sampling.
}

HO. SNIPISE

Number of samples collected.

SAMPLER'S IRITIALS 
DO NJT REMJVE From SRP

Witinout Approval

HEALTH PROTECTION OEPART EENT

DPSOP REF 271-1
Append1x E-3

Drsa 271-1-323

Revision 1

Approval Date

Page 1 of 18

WELL WATER SAMPLING PAOCEDURE

FOR NONZAUIOACTIVE PARAIETERS

\section{PURZOSE:}

To provide instructions for sainpling well water for analyses of nonradioactive parameters.

\section{INTROOUCTION:}

Gruundwater is collected routinely for hazardous waste analyses from monitoring wells installed in the vicinity of liquid and dry: waste disposal sites. Some disposal sites are no longer operative.:

Special well water samples are also taken from ooth permanent and temporary wells e.g., plume development.

\section{PROCEDURE:}

\section{A. GENERAL INFORIAATION}

\section{Scheduling}

The routine gruunjwater monitoring program for hazardous waste analyses is carried out following tne direction of Energy Conservation and Environmental Control (ECEC) and tne regulating agency, South Carolina Department of Health and Environmental Control (OHEC).

Usually in Decemiver, ECEC sends Health Protection a memorandum detailing the required analyses (e.g., annual, juarterly, site specific) for groundwater wells veing monitured for hazardous waste.

Groundwater weils monitored for hazardous waste are listed on the Health Protection Environmental Collections posted scinedule. In addition, following receipt of the memorandum from Special Programs, the groundwater program field supervisor prepares an inter-office memorandum listing the first quarter sampling dates.

Example: Inter-Office Mernorandur:

To: Environmental Collections Supervisor, plus distribution

From: Groundwater Progran Supervisor

Title: (Year) First Quarter Sampling of Groundwater Monitoring Wells being Analyzed for Hazardous Waste

\begin{tabular}{|c|c|c|}
\hline Mells & Proposed Sampling Date & Remarks \\
\hline $\begin{array}{l}709-6 \text { \#1 } \\
200-4 \text { S.8. } \# 55-\# 71\end{array}$ & $\begin{array}{l}\text { Jaา. } 4 \text { \& } 5 \\
\text { Jaา. } 4 \text { \& } 5\end{array}$ & \\
\hline $\begin{array}{ll}200-\bar{r} & \text { S.B. } \\
300-M & \text { S.B. } \# 1 \mathrm{~A}-\| 79 \\
\end{array}$ & $\begin{array}{l}\text { Jอา. } 4 \text { \& } 5 \\
\text { Jอา. } 11 \text { \& } 12\end{array}$ & 176 dry \\
\hline
\end{tabular}


$A, 1 \ldots$

The wells listed in the example are priority wells (anz otners will be added as we continue) and are always sampled first in the quazter; however, nonpriority wells are also listed in the inter-office ne:.orandum.

Tnis inter-office menorandum with scheduled sampling daies is repeated each quarter.

\section{Chain of Custody}

\subsection{Transfer of Custody and Snipment:}

When transferring the possession of the samples, the transferee signs and records tne date and time on the Cnain-of-Custody Record. Custody transfers account for each individual sample, although samples may be transferred as a group.

The Groundwater Progran supervisor is responsiole for seeing that samples are properly preserved, labeled, packaged, and dispatched to the several laboratories for analysis. Tnis responsibility includes filling out, dating, and signing the appropriate portion of the Chain-of-Custody Record. Preservation techniques employed will be those prescribeJ by EPA (see Attachment 1 ).

The sample container is then placed in a cooler along witn "blue ice" to maintain the sample at approximately $4^{\circ} \mathrm{C}$. Samples must be packed so as not to break. All packages sent to the laboratories should be accompanied by the Chain-of-Custody Record and otner pertinent forms. A copy of these forms should be retained by the Groundwater Program supervisor.

Samples are delivered to SRP Laboratories and shipped to the offolant laboratory on the second day of sampling (Thursday) each week via an air priority service. If air priority service is not available, a nor-stop flight should be selected for s.mple transport. If no non-stop flight is available, every attempt is made to schedule the transfer via the same airline throughout the flight. This latter provision helps minimize delays and other problems encountered with transfers between airlines. Transportation receipts are retained as part of the permanent chain of custody documentation:

\subsection{Laboratory Custody Procedures:}

Chain of custody procedures are also necessary in the laboratory from the time of sample receipt to the time the sample is discarded. The following procedures are followed in the laboratory:

Samples are received in the laboratory and logged in by the Laboratory Supervisor . The kaboratory Supervisor verifies that the items on the custody transfer agree with what is received and that all containers are in good condition. If there is any discrepancy or if any samples are received broken in snipment, the sampler is notified. The Lavoratory Supsrvisor signs the custody sheet. A file copy is maintained. 
$A, 2.2 \ldots$

In the offolant iavoratory, each sample fraction is assigned a unique laboratory number by affixing a gummed tape label with a five-digit number. The sample numver, sample identification, date, description, and parameters requested along with the project number, date, and person who received the sanple are recorded on the laboratory work request form. Copies of the laboratory work request are distributed to the various laboratory section managers who are responsible for assigning and scheduling the particular analyses to be performed. The Data Manager also is responsible for recording the sample identification, sample date, and required parameters in a permanent bound logbook.

Once samples are received and logged, they are stored at $4^{\circ} \mathrm{C}$. The sample custodian maintains the custody forms and technicians are to sign for samples when tney remove them for analysis. Samples are maintained until the data are completed, reviewed and reported, and disposal instructions are provided by the Project Manajer.

Sample Collection Botties -

Routine: From Stores, 735-A Water Quality (WQ) Lav, and offplant lavoratory to HP Environmental Collections (EC).

Special: From 320-M Lao, 773-A Lad, or Laboratories listed above to Sample Group.

Samples -

Routine: From EC to 772-D LaD, 735-A WQ Lab, and offplant laboratory on form EM-7.

Special: From EC or other Sample Group to 320-M Lao, 773-A Lab, or Laooratories listed aoove on form EM-8.

Field Measurements -

Routine: Fron EC to HP Data Evaluation (DE) on forms EM-1 (priority wells) and EM-2 (nonpriority wells) and then to Energy Conservation and En:ironmental Control (ECEC).

Special: From EC or other Sample Group to DE and then to ECEC.

Laooratory Results ${ }^{l}$ -

Routine: From 735-A WQ Lai (Env. Chemistry) to DE on forms EM-3 (priority wells) and EM-4 (nonpriority wells), and then to ECEC.

Routine: From $77 Z-D$ Lab to $D E$ on forms EM-5 (priority wells) and EM-6 (nonpriority wells), and then to ECEC.

Routine: From of fplant laboratory to EC on offplant laboratory reporting form for review and then data, with any pertinent corments, is given to DE for transinittal to ECEC.

Special: From participating Laboratories to EC or otiner special groups, and then ECEC and Custodian.

$\rightarrow \infty$

1 The summary of laboratory methods for analyzing for hazardous waste by onplant of offplant laooratories is siown in Attachment \#2. 
$A, 2.2 \ldots$

Data Evaluation -

Routine: From ECEC to offplant laboratory for (Ref Data Management Services, Scope of Work Dy ECEC, dated 1/17/83) to offplant laboratory:

- Statistical test of raw datal

- Comparison to Drinking Water Standard (DWS) or Arbitrary Standard

- Grapnic display of data failing statistical test and outside DWS.

3. Quarterly and Annual Groundwater Monitoring Parameters and Laboratories Performing Analyses

\subsection{Routine Program}

[NOTE: Quarterly analyses are indicated by an *. An annual (comprenensive) analysis includes all parameters listed, insluding the quarterly.]

$3.1 .1 \frac{\text { Offplant Lao }}{\text { Sulfate }}$
Fluoride
Dissolved Organic Caroon*
Phenols
Foaning agents
Corrosivity
Odor
Selenium
Silver
Copper
Iron
Manganese
Zinc
Radium, Total
Sulfide
Cyanide
Arsenic
Barium

3.1 .2 735-A WQ LaD

Total dissolved solids*

Chloride*

Gross alpina

Gross beta

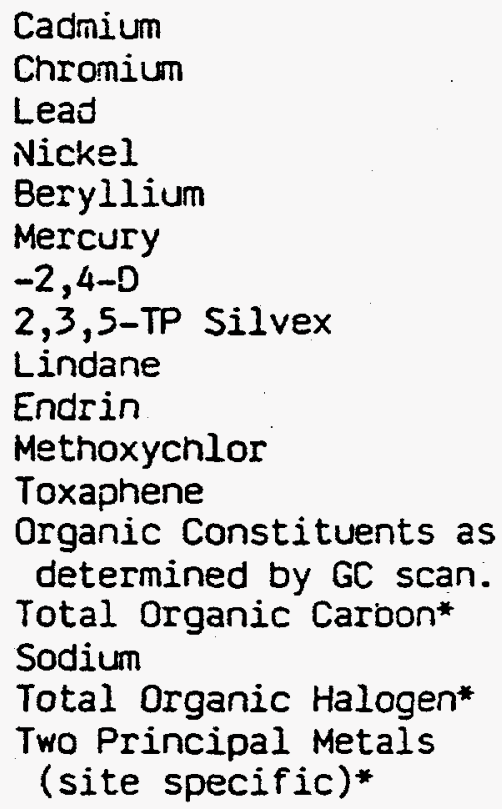


$A, 3 \ldots$

[NOTE: Quarterly analyses are indicated by an *. An annual (comprehensive) analysis includes all parameters listed, inclusing the quarterly.]

\subsubsection{2-D Lab}

Coliform, total

3.1.4 735-A Env. Collections (Field Measurements) Temp $\left(C^{\circ}\right)^{*}$

$\mathrm{pH}^{*}$

Specific conductivity*

Water level*

\subsection{Special Samples}

3.2.1 offplant, 735-A, and 772-D

All parameters listed in section 3.1

3.2.2 320-M Lad and 773-A Lab

Organic constituents as determined by GC scan.

\section{B. SAFETY}

\section{General}

1) Personnel will wear safety glasses and rwber gloves when performing all phases of the sampling and handling procedure.

2) Housekeeping must be maintained at all sample sites. Health Protection supervision should be notified when weeds and grass are growing on the well site.

3) Any unsafe conditions and hazards should be reported to supervision immediately.

4) When pumping, all equipment must be properly grounded.

5) Acids must De transported in special containers.

6) When performing field operations, an acid wash station must be available.

\section{Requirements for Sampling in Regulated Areas}

1) Personnel entering Regulated Areas must familiarize themselves and comply with all safety rules and protective clotning procedures.

2) A Tnyas must. be carried and used in order to monitor each sample site, sample, and sampling equipment. When entering a Regulated Area, the Thyac, must be on at the entrance and during the entire sampling period. 
$B, 2 \ldots$

3) Health Prutection Area Survey must De notified prior to sampling wells inside the Durial ground.

4) When moving from one well site to another inside the burial ground fence, the tecnnician will remove shoe covers at a time when entering venicle and put on shoe covers prior to dismounting from venicle.

[NOTE: Snoe covers and any other Regulated Area protective equipment will De disposed of in approved receptacles.]

5) Vehicle tires must be checked prior to leaving a Regulated Area. The vehicle must not leave the area until Health Protection (Area Survey) gives permission.

\section{EQUIPMENT REQUIRED}

1. General

- Stainless steel puller

- Rope

- Generator (used when pumping)

- Measuring tape, steel $200 \mathrm{ft}$

- Tape, one roll, filament

- Logbook

- Pens (2), water resistant ink

- Thyac

- Spare clean pullers, locks

- Bottles

- Coolers: 6-8, received from offplant laboratory and containing sample bottles, 2 containing frozen blue ice packs.

- Hydrolad water quality monitor, $4041^{2}$

- Preservativel

\section{Protective}

- Basic: rubber gloves, leather gloves, safety glasses

- Portable eye wash station

- Regulated Area: Follow posted requirements.

Isee Attachment 1 .

2The Hydrolầb is used for measuring conductivity, temperature, and pH. It must be calibrated weekly oefore using and all calibration data and results must be posted in the hazardous waste logbook (wells being sampled that week). See DPSOL 271-1-415 for Hydrolab calibration. 


\section{BUCKET SAMPLING}

1) Select coslers containing Dottles for wells to be sampled. [NOTE: Eacn well set of Dottles (i.e., bottles for one well) will arrive onplant from an offplant laboratory in the same cooler and are returned to the offplant laboratory the same way. The blanks for volatile organics or organic constituents accompany the set of empty bottles from of fplant laboratory to SRP and the full bottles back to offplant laboratory in the same cooler. Obtain frozen ice paciks from the freezer and place in separate coolers and close the lids.]

2) Ootain equipinent listed in division $\mathrm{C}$ and proceed to load in vehicle.

3) Proceed to the sample site with equipment: Wear glasses and rubber gloves for your personal protection. Personal contact with the bailer can introduce both chemical and biological contaminants in the sample. [NOTE: If well is located inside a Regulated Area, wear prescribed protective clothing and monitor area with Tnyac. If a reading greater than $24,000 \mathrm{c} / \mathrm{m}$ is obtained, leave the area and notify Health Protection supervision.]

4) Unlock and remove well cap and stainless steel sample bucket suspended from cap.

[NOTE: Be watchful of wasp nests and alert for strong odors emitting from hazardous waste wells. If odor persists, request area survey to monitor.]

5) Using etched steel tape, measure depth of water oelow top of pipe and record in logoook (reference procedure 271-1-406).

6) Rinse sample bucket with distilled water and attach rope with snap latch to the 4-ft chain extension on the bucket.

7) Ensure that sample bucket and rope do not touch the ground. Hang bucket on metal rod provided.

8) With hands over the well (not to the side), lower sample bucket slowly into well until it is below the water surface.

[NOTE: Wear rubber gloves over leather gloves.]

9) Raise bucket of water from well by pulling straight up with a smooth motion.

10) If the rope has touched the water, remove it from service. [NOTE: LOOK for discoloration of the rope.]

11) Pour the first bucket of water into a 6-gallon jug marked "Waste Water", to ensure removal of the surface film on the water column.

12) Repeat steps 7) and 8).

13) Using wate= from tnis bucket, thoroughly rinse the Hydrolab probes and its matcining scaple container and then pour the remainder of the water into the Hyuro:ao sample container. 
D...

14) Imnediately insert the Hydrolab prooes into the Hydrolab sample cup of sample wate: (Ref procedure 271-1-415). Measure and record in logboak (see Attachnent 3 ):

- Temperature, oc

- pH

- Conductivity, umhos/cm

15) Pour the water from tne Hydrolab sample cup into the 6-gallon jug marked "Waste Water".

16) Rinse the sample cup and the Hydrolab probes thoroughly with distilled water. Add distilled water to cup and screw cup to Hydrolab to keep probes moist and ready to use at the next well.

17) For the well being sampled, remove all sample bottles from the cooler. Check labels and layout bottles with preservative as required, in the order shown in Attachment 1 .

[NOTE: All sample containers are premarked with parameter and preservative required. fiJd the site, well number, and date (i.e., 300-M S.B., well \#1, $3 / 10 / 83)$.

18) Repeat steps 7) and 8) until all bottles are filled.

[NOTE: The raference procedure for coliform sampling is OPSOL 271-1-418.]

a) Wear protective clothing as required.

D) As each bottle is filled, imediately add preservative as requiref and cap bottle.

[NOTE: Volatile organic samples should be poured in a manner to reduce. exposure to air (no bubbles in vial) and immediately placed in a secondary container.]

19) Ensure as each sample is collected that all pertinent information (color, sediment, odor, etc.) is recorded in the logbook (see Attachment 13 ).

20) Secure sampling bucket to snap ring in cap, replace well cap, lock well, perform housekeeping around well, load samples and equipment, and move to the next well.

21) Repeat steps 3) through 20) for each well being sampled.

22) After each bottle is filled, preservative added to sample bottle, the bottle is capped and labeled, check the sample for leaks and for complete information on label. Place bottles in coolers containing frozen, seeled ice packs. At the end of the first day of sampling, the 13 samples taken from each well should be handled as follows:

a) The nine samples going to offplant laboratory should remain in the offplant laboratory cooler containing blanks.

D) Deliver one sample (for coliform) to the 772-0 Laboratory and plase in refrigerator. Sample analysis request accompanies samples to 772-3. [NOTE: Tnis sample can be held on ice in cooler overnight, but must be deliverez and analysis started within 24 hours from time of sampling. Maintain on ice after delivery.] 
$D, 22) \ldots$

c) Tnree samples scheduled for delivery to 735-A Labaratory can remain in the EC cooler until samples are delivered to 735- $h$ Laboratory.

d) Alert Snipping, phone 3483, that a shipment of sanples will be ready for snipment of ssite the following day. Provide tine when samples will be delivered, the date to be shipped, method of sipment, and shipping request number.

[NOTE: One shipping request number is used for the calendar year.]

23) Complete second day of week's sampling schedule by repeating steps 1) through 20) including delivering of coliform samples to the 772-0

Laboratory. Obtain signed receipt for samples.

24) Complete chain of custody forms for samples going to $735-A$ and offplant laboratories.

25) Deliver samples to 735-A Water Quality Laboratory anj have Laboratory custodian sign chain of custody form for receipt of samples. Each sample set ( 3 samples) should remain in individual coolers and stored apart in the refrigerator.

26) Check each offplant laboratory sample set ( 9 samples) carefully to ensure they are properly packed and iced (ice packs).

[NOTE: Each set will be shipped in an individual cooler.]

27) Place lid on each cooler and secure by wrapping reinforced tape around cooler and lid at both ends.

28) Deliver coolers with samples to Snipping by 3:00 p.t.. on day of shipment (second day of sampling schedule for the week):

a) Obtain flight number and time of arrival at final destination airport.

D) Imnediately notify Laboratory of above information.

29) Have offplant laboratory:

a) Notify SRP by telephone immediately after receipt of samples and their condition.

b) Return chain of custody receipt to SRP.

\section{E. PUMP SAMPLING}

1) Select coolers containing bottles for wells to be sa:pled.

[NOTE: See note at step 0,1$).$ ]

2) Ootain all other equipment listed in division $C$ and proceed to load in venicle.

3) Hook gênérător to venicle (Ref procedure 271-1-212). 
E...

4) Proceed to the sample site with equipment. Hear glasses and rubber gloves for your personal protection at each well site. Gloves also protect the sample since personal contact with equipment can introduce both chemical and biological contaminants in the samples.

[NOTE: See Note at step 0,3$).$ ]

5) Position generator near well to be sampled, but on side opposite to discharge side of pump (follow Ref procedure 271-1-119).

6) Remove locik and cover from pump.

[NOTE: Be watchful of wasp nests and alert for strong odors emitting from hazardous waste wells. If odor persists, request Area Survey to monitor.]

7) Using etcined steel tape, measure depth of water from top of well casing and record in logbook (reference procedure 271-1-406).

8) Suotract deptn of water from depth of well (inside oottom of screen) which is posted for each well in the logbook (see Attachnent \#3). This will give the length of the water column in feet. Record in logbook.

9) Turn to table posted in logbook (see Attachment 13). Look in left margin for feet measured in well (i.e. 10) and then move across the page to the column under the fraction of a foot measured (i.e. 0.5). Record in the logbook the volume of water ( 10.98 gals) to be removed for a column of water $10.5 \mathrm{ft}$ long.

[NOTE: The volume for any given length of pipe was multiplied by 4 in order to show the volume of water to be removed from the well. The reason is the requirement that four volumes be removed from a well prior to sampling.]

10) Ensure pump switch is OFF and system is grounded; then connect pump cord to power source.

11) Cneck all valves, gages, etc. The discharge line valve must be open.

12) Place 6-gallon jugs marked "Waste Hater" under the pump nozzle. Have spares nearby.

13) Start power source.

14) After again checking valves (ensure discharge line is closed, but open quickly when pump starts) turn pump switch to $\mathrm{ON}$ and remove four volumes of tne water column.

a) If the well goes dry while pumping, allow for full recovery (measure water level again). [NOTE:"Sometimes a well will not provide four volumes.]

b) When recovery is complete, throttle pump by partially.closing dischar valve and proceed witn sampling. 
$E, 14) \ldots$

c) If experience snows a great deal of time must elapse before full recovery, proceed to the next well and empty the "Waste Water" pumped in step $E, 14), a$ ) into an approved receptacle.

[NOTE: If not sampled within 24 nours the well must be pumped again.]

d) If the well nistory indicates the well being pumped will not provide the volume of water required for removal of four volumes of the water column, remove all sample bottles from the cooler before the pump is turned on.

(1) Cneck the labels and layout bottles and preservatives, as required, in the order shown in Attachnent $\# 1$.

[NOTE: Ail sample containers are premarked with parameter being sampled and preservative required.]

(2) Add site number, well number, and date as shown in example below:

Example: Site: 300-M Seepage Basin

Well \#: 1

Date: $\quad 3 / 10 / 84$

15) As pumping continues:

a) Keep check on volume Deing removed.

D) Replace filled jug marked "Waste Water" with an empty jug.

C) Repeatedly fill the Hydrolab sample cup with pumped water. [NOTE: This acclimates sample cup temperature to wel] water temperature.]

d) Insert calibrated Hydrolab (reference procedure 271-1-415) probes in cup each time it is filled.

e) Ooserve changes, if any, in conductivity, temperature, and $\mathrm{pH}$. With the removal of four volumes of the water column, these parameters should stabilize.

f) After removal of four volumes of water, measure conductivity, temperature, and pH. Record in logbook.

g) Pour sample cup water into "Waste Water" jug.

h) Rinse the Hydrolab sample cup and the Hydrolab probe thoroughly with distilled water. Place probes in cup containing distilled water to keep moist during transit.

[NOTE: "Wipes" or any otner material must not be used on cup or probes.]

16) Fill each oottle from the sample nipple in the order in which the bottles were laid out.

[NOTE: The sample nipple is on the main discharge line from the pump. A slight back pressure caused by partially closing the main valve will

increase the flow from the nipple.]

17) Immediately after bottle is filled, cap, place in secondary container, and return.to-cooler containing trip blank.

[NOTE: When sampling for volatile organics, the water sampled should have minimum contact with air and snould not splash into the receiving container.J 
E...

18) Add preservatives as required. [NOTE: Wear protective clotning as required.]

19) Cap Dottle firmly. Ensure there is no leak for each bottle.

20) Cneck label for complete information (should have been filled in earlier) and place each sample in cooler.

[NOTE: All samples from the same well (called a set) go in the same cooler for transport.]

21) When sampling is complete, turn pump switch to OFF. Unplug pump from power source and replace cover on pump.

22) Ensure that all pertinent information (color, sediment, odor, etc.) pertaining to the well and the sample is recorded in the logbook (see Attacrment 3 ).

23) Perform housekeeping around well, load samples and equipment, and move to the next well.

24) Repeat steps 1) through 23) for each well being sampled this day.

25) At the end of the first day of sampling, the 13 samples taken from each well snould be handled as follows:

a) The nine samples going to offolant laboratory should remain in the offplant laboratory cooler with the blanks.

D) Deliver one sample (for coliform) to the 772-D Laboratory and place in refrigerator. Suomit sample analysis request with sample. iNOTE: This sample can De held on ice in cooler overnight, but must de delivered and analysis started within 24 hours from time of sampling. Maintain on ice after delivery.]

c) Tnree samples scheduled for delivery to 735-A Laboratory can remain in EC cooler until samples are delivered to 735-A Laboratory.

d) Alert Snipping, phone 3483, that a shipment of samples will be ready for shipment offsite the following day. Provide time when samples will be delivered, the date to be shipped, metinod of shipment, and shipping request number.

[NOTE: One shipping request number is used for the calendar year.]

26) Complete second day of week's sampling schedule by repeating steps 1) tnrough 24) including delivering of coliform samples to the 772-D Ladoratory. Obtain signed receipt for samples.

27) Complete chain of custody forms for samples going to $735-A$ and offplant laooraţories.

28) Deliver samples to 735-A Water Quality Laboratory and have Laboratory $r$ Custodian sign chain of custody form for receipt of samples. Each sample set ( 3 samples) should remain in individual EC coolers and stored apart in the refrigerator. 
E...

29) Check each offplant laboratory sample set ( 9 samples) carefully to ensure they are properly packed and iced (ice packs).

[NOTE: Each set will be shipped in an individual offplant laboratory cooler.]

30) Place lid on each cooler and secure by wrapping reinforced tape around cooler and lid at both ends.

31) Deliver coolers with samples to Shipping by 3:00 p.m. on day of shipment (second day of sampling schedule for the week):

a) Ootain flight number and time of arrival at final destination airport.

b) Immediately notify Laboratory of above information.

32) Have offplant laboratory:

a) Notify SRP by telephone immediately after receipt of samples and their condition.

b) Return chain of custody receipt to SRP. 


\section{ATTACHMENT}

REQUIRED CONTAINERS, PRESERVATION TECHNIQUES, HOLOING TIMES, AND LABORATORIES PERFORMING ANALYSES

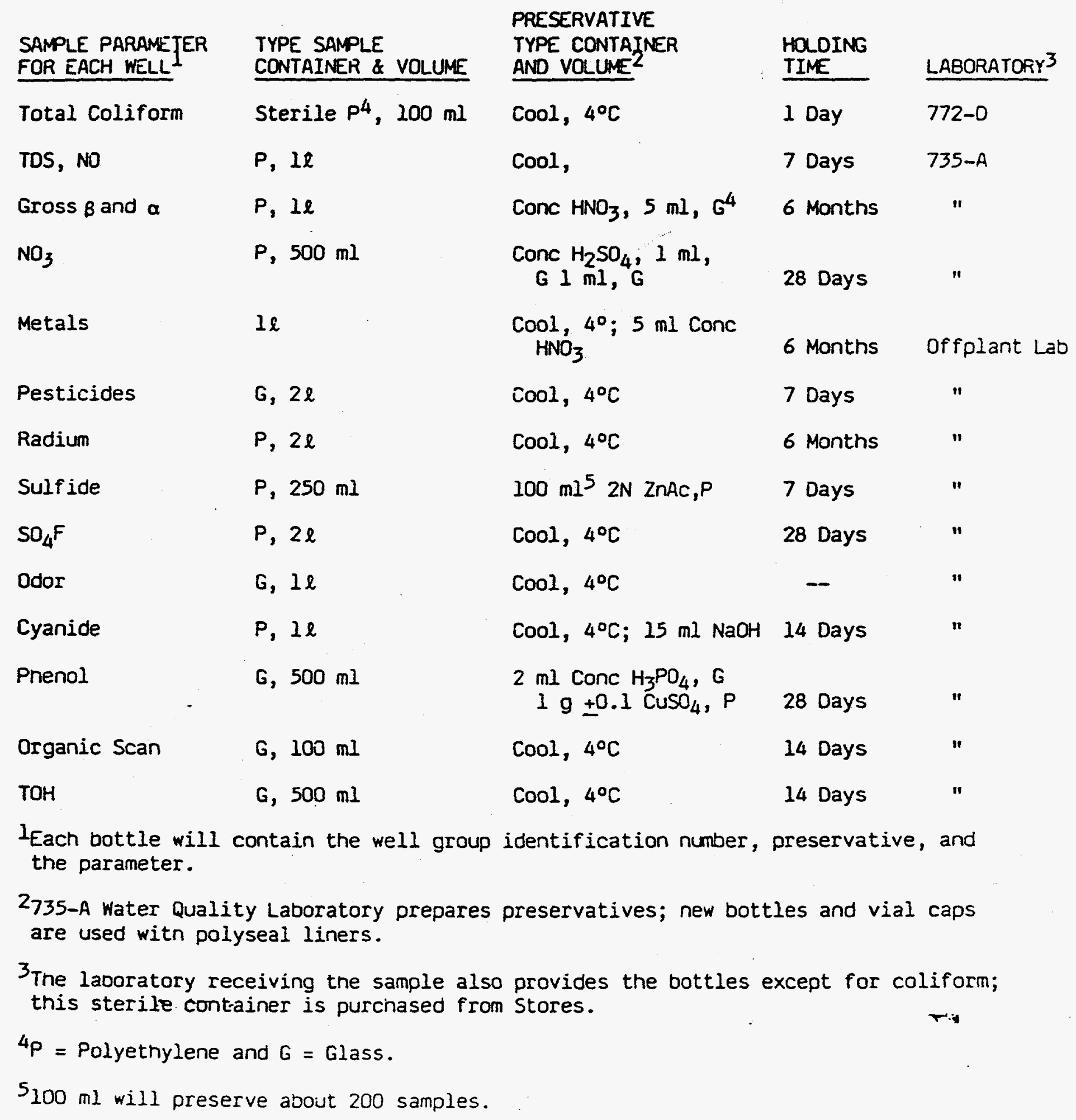


ATTACHEENT 2 .

SUMMARY OF METHOUS FOR ANALYSES - HAZAROOUS WASTE

PARAYETER

Cyanide

Sulfate

Dissolved Organic Carbon

Total Organic Carbon

Total Organic Halogens

Fluoride

Phenol

Surfactants
Corrosivity
Odor
Sulfide

METALS:

Arsenic

Barium

Beryllium

Cadnium

Cnromium

Copper

Iron

Lead

Manganese

Mercury

Nickel

Selenium

Silver

Sodium

Zinc

Total Radium

Pesticides

Herbicides

GC Sean $\therefore$.
REFERENCE ${ }^{a}$

EPA Method 335.2

EPA Method 375.2

EPA Method 415.1

EPA Method 415:1

EPA Method 450.1

EPA Method 340.1

EPA Method 420.2

EPA Method 425.1

Method 5.3

EPA Method 140.1

EPA Method 376.1

EPA Method 206.2

EPA Method 208.1

EPA Method 210.2

EPA Method 213.2

EPA Method 218.2

EPA Method 220.2

EPA Method 236.1

EPA Method 239.2

EPA Metinod 243.1

EPA Method 245.1

EPA Method 249.2

EPA Method 270.2

EPA Method 272.2

EPA Method 273.1

EPA Method 289.1

Standard Metinods,

Method 705

EPA Method 608

EPA, Federal

Register Vol 38, No. 75, Part II

EPA, Federal

Register Vol 44, No. 231
METHOO DESCRIPTION

Colorimeteric without distillation

Automated methylthymol blue

colorimetric

Filter sample through 0.45 micron filter, analyze by combustion

Combustion Method

Colorimetric, SPAONS with Bellack Distillation

Automated 4-AAP colorimetric with Distillation

Colorimetric MBAS

Corrosivity towards steel

Threshold odor

Iodine titration

AA, Graphite Furnace

$A A$, Direct Aspiration

AA, Grapnite Furnace

AA, Graphite Furnace

$A A$, Graphite Furnace

$A A$, Graphite Furnace

AA, Direct Aspiration

AA, Graphite Furnace

$A A$, Direct Aspiration

Manual cold vapor with no digestion

Manual cold vapor with no digestion

AA, Graphite Furnace

$A A$, Graphite Furnace

$A A$, Direct Aspiration

$A A$, Direct Aspiration

Radium by precipitation

Organochlorine Pesticides in Industrial Effluents, GC/EC

Chlorinated Phenoxy Acid Herbicides in Industrial Effluents, GC/EC

Analysis of Trihalomethanes in

Driniking Water by

Liquid/Liquid Extraction 
OU NOT REMOVE FrOM SPP

DPSO 271-1-323

Without Approval

Revision 1 Page 16 Conto

ATTACHENT 2 , Contd

PARANETER

Color

Special conductivity

Turbidity

Total dissolved solids

pH

Cinloride

Temperature

Nitrate

Nitrite

Gross alpna-beta activity

Coliform

REFERENCE ${ }^{a}$

Not in print yet

Not in print yet

DPSOL 271-1-415

OPSO 271-318

DPSOL 271-310

Not in print yet

OPSOL 271-1-415

DPSOL 271-306

DPSOL 271-1-415

DPSOL 271-313

DPSOL 271-261

DPSOL 271-261

DPSOL 85-4W89.1
METHOD DESCRIPTION

Visual comparative method Beckman bridge

Hydrolab (analyzed in field)

Need revised Hach method

Filterable residue (revised)

Corning procedure

Hydrolab (analyzed in field)

End point titration

Hydrolab (analyzed in field)

Technicon automated

Technicon automated

[NOTE: All references are on file and available for inspection in 735-9A.

These include three sets of the offplant laboratory procedures titled

"Procedures for Analysis of Groundwater Monitoring Samples for Du Pont - SRP."]

aEPA Methoôs = Methods for the Chemical Analysis of Water and Waste EPA, March 1979.

Standard Methods - Standard Methods for the Examination of Water and Waste Water, 15tn Edition, APHA-AWWA-WPCF, 1980. 
DO NOT REMOVE From SRP Without Approval

DPSA 271-1-323

Revision 1 Page 17 Contd

\section{ATTAEHENT 3}

\section{LOGBOOK HEADINGS}

SITE AND WELL

COORDINATES: $N$

E
EVALUATION (TOP OF CASING)

LENGTH ( $\mathrm{ft}$ ) FROM TOP OF CASING TO BOTTOM OF SCREEN

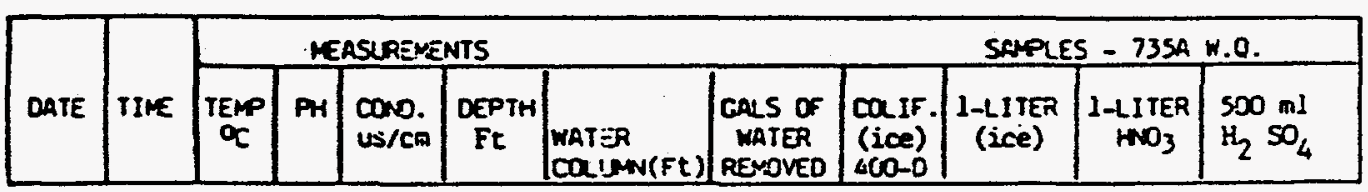

\begin{tabular}{|c|c|c|c|c|c|c|c|c|c|c|c|}
\hline $\begin{array}{l}\text { METALS } \\
\text { I-LITER } \\
\text { HOH }\end{array}$ & $\begin{array}{l}\text { PESTICIOES } \\
.5 \text { GA } \\
\text { PASS } \\
\text { (ICE) }\end{array}$ & $\begin{array}{l}\text { RADIUH } \\
.5 \text { CAL } \\
\text { (ICE) }\end{array}$ & $\begin{array}{l}\text { SULF IOE } \\
\text { 8O.2. POLY } \\
\text { ZnAC }\end{array}$ & $\begin{array}{l}\mathrm{SO}_{4} \mathrm{~F} \\
.5 \mathrm{CAl} \\
\text { (ICE) }\end{array}$ & $\begin{array}{l}\text { OOR } \\
1 \text { LIITER } \\
\text { CLASS } \\
\text { (ICE) }\end{array}$ & $\begin{array}{c}\text { CWANICE } \\
\text { L-LITER } \\
\text { NAOH }\end{array}$ & $\begin{array}{l}\text { Frina } \\
202 \text { GLISS } \\
\mathrm{H}_{3} \mathrm{PS}_{4} \\
\mathrm{CSSO}_{4}\end{array}$ & $\begin{array}{l}\text { OFG. } \\
\text { SCAN } \\
100 \text { ml } \\
\text { GLASS } \\
\text { (ICE) }\end{array}$ & Ітон & REMARKS & INITIALS \\
\hline
\end{tabular}


TABLE -

PUAPING WELLS

FOUR YOLUMES (GAL.) OF H2O in $4^{\circ \circ}$ CASING WELLS

$\begin{array}{llllllllllll}\text { Water Column } & 0.0 & 0.1 & 0.2 & 0.3 & 0.4 & 0.5 & 0.6 & 0.7 & 0.8 & 0.9\end{array}$ (Ft.)

\begin{tabular}{|c|c|c|c|c|c|c|c|c|c|c|}
\hline 0 & 0 & 0 & 1 & 1 & 1 & 1 & 2 & 2 & 2 & 2 \\
\hline 1 & 3 & 3 & 3 & 3 & 4 & 4 & 4 & 4 & 5 & 5 \\
\hline 2 & 5 & 6 & 6 & 6 & 6 & 6 & 7 & 7 & 7 & 8 \\
\hline 3 & 8 & 8 & 8 & 9 & 9 & 9 & 9 & 10 & 10 & 10 \\
\hline 4 & 11 & 11 & 11 & 11 & 12 & 12 & 12 & 12 & 13 & 13 \\
\hline 5 & 13 & 13 & 14 & 14 & 14 & 14 & 15 & 15 & 15 & IS \\
\hline 6 & 16 & 16 & 16 & 17 & 17 & 17 & 17 & 18 & 18 & 18 \\
\hline 7 & 18 & 19 & 19 & 19 & 19 & 20 & 20 & 20 & 20 & 21 \\
\hline 8 & 21 & 21 & 22 & 22 & 22 & 22 & 23 & 23 & 23 & 23 \\
\hline 9. & 24 & 24 & 24 & 24 & 25 & 25 & 25 & 26 & 26 & 26 \\
\hline 10 & 26 & 27 & 27 & 27 & 27 & 27 & 28 & 28 & 28 & 29 \\
\hline 11 & 29 & 29 & 29 & 30 & 30 & 30 & 31 & 31 & 31 & 31 \\
\hline 12 & 32 & 32 & 32 & 32 & 33 & 33 & 33 & 33 & 34 & 34 \\
\hline 13 & 34 & 35 & 35 & 35 & 35 & 36 & 36 & 36 & 36 & 37 \\
\hline 14 & 34 & 37 & 37 & 38 & 38 & 38 & 38 & 39 & 39 & 39 \\
\hline 15 & 39 & 40 & 40 & 40 & 40 & 41 & 41 & 41 & 42 & 42 \\
\hline 16 & 42 & 42 & 43 & 43 & 43 & 43 & 44 & 44 & 44 & 44 \\
\hline 17 & 45 & 45 & 45 & 45 & 46 & 46 & 46 & 47 & 47 & 47 \\
\hline 18 & 47 & 48 & 48 & 48 & 48 & 49 & 49 & 49 & 49 & 50 \\
\hline 19 & 50 & 50 & 50 & 51 & 51 & 51 & 52 & 52 & 52 & 52 \\
\hline 20 & 53 & 53 & 53 & 53 & 54 & 54 & 54 & 54 & 55 & 55 \\
\hline 21 & 55 & 56 & 56 & 56 & 56 & 57 & 57 & 57. & 57 & 57 \\
\hline 22 & 58 & 58 & 58 & 59 & 59 & 59 & 59 & $60^{\circ}$ & 60 & 60 \\
\hline 23 & 60 & 61 & 61 & 61 & 61 & 62 & 62 & 62 & 63 & 63 \\
\hline 24 & 63 & 64 & 64 & 64 & 64 & 64 & 65 & 65 & 65 & 65 \\
\hline 25 & 66 & 66 & 66 & 67 & 67 & 67 & 67 & 68 & 68 & 68 \\
\hline 26 & 68 & 69 & 69 & 69 & 69 & 70 & 70 & 70 & 70 & 71 \\
\hline 27 & 71 & 71 & 72 & 72 & 72 & 72 & 73 & 73 & 73 & 73 \\
\hline 28 & 74 & 74 & 74 & 74 & 75 & 75 & 75 & 75 & 76 & 76 \\
\hline 29 & 76 & 77 & 77 & 77 & 77 & 77 & 78 & 78 & 78 & 79 \\
\hline 30 & 79 & 79 & 79 & 80 & 80 & 80 & 80 & 81 & 81 & 81 \\
\hline 31 & 82 & 82 & 82 & 82 & 83 & 83 & 83 & 83 & 83 & 84 \\
\hline 32 & 84 & 84 & 84 & 85 & 85 & 85 & 86 & 86 & 86 & 86 \\
\hline 33 & 87 & 87 & 87 & 88 & 88 & 88 & 88 & 89 & 89 & 89 \\
\hline $38 \div$ & 89 & 90 & 90 & 90 & 90 & 90 & 91 & 91 & 92 & 92 \\
\hline 35 & 92 & 92 & 93 & 93 & 93 & 93 & 94 & 94 & 94 & 94 \\
\hline
\end{tabular}


This appendix includes the water-level elevations that were used to construct Figures 5-3,5-4,5-5, and 5-6 as well as others that were measured before collecting water samples for analysis.

Appendix F-1 includes the water-level measurements that were used to construct most of Figure 5-3, Water Table Elevation Map for Spring 1984. Most of these measurements were all made at the end of July to obtain a synoptic set of water-level elevations. Wells other than water-table wells were also measured during this time period and they are included in Appendix F-1. In order to extend the water table map to the Silverton Road waste site area, it was necessary to use water-level measurements taken while collecting samples for chemical analysis and these water levels are given in Appendix F-2. These measurements were made in May and June 1984. For construction of Figure 5-4, Potentiometric Map of the Elevation Interval where the Top of the Screen is Between 146 and $187 \mathrm{ft}$, i.e., $\sim 50 \mathrm{ft}$ Below the Green Clay, for April-June 1984, the measurements taken in July 1984 did not provide sufficient areal coverage. So the water-level measurements obtained while collecting samples for chemical analyses given in Appendix F-2 were used. This resulted in a broadened time span but provided better areal coverage.

The same situation applied to the construction of Figure 5-5, Potentiometric Map of the Elevation Interval where the Top of the, Screen is Between 100 and $144 \mathrm{ft}$, i.e., in Basal Tertiary Sediments for April-June 1984, and the same solution was applied, i.e., the measurements are given in Appendix F-2. For Figure 5-6, Potentiometric Map of the Elevation Interval where the Top of the Screen is Between 14 and $76 \mathrm{ft}$, i.e., Upper "Tuscaloosa" Formation, for May 1984, the water-level measurements made while collecting samples for chemical analyses, Appendix F-2, were used but the time period was restricted to May 1984 without sacrificing any areal coverage. 


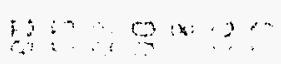

APPENDIX F-1

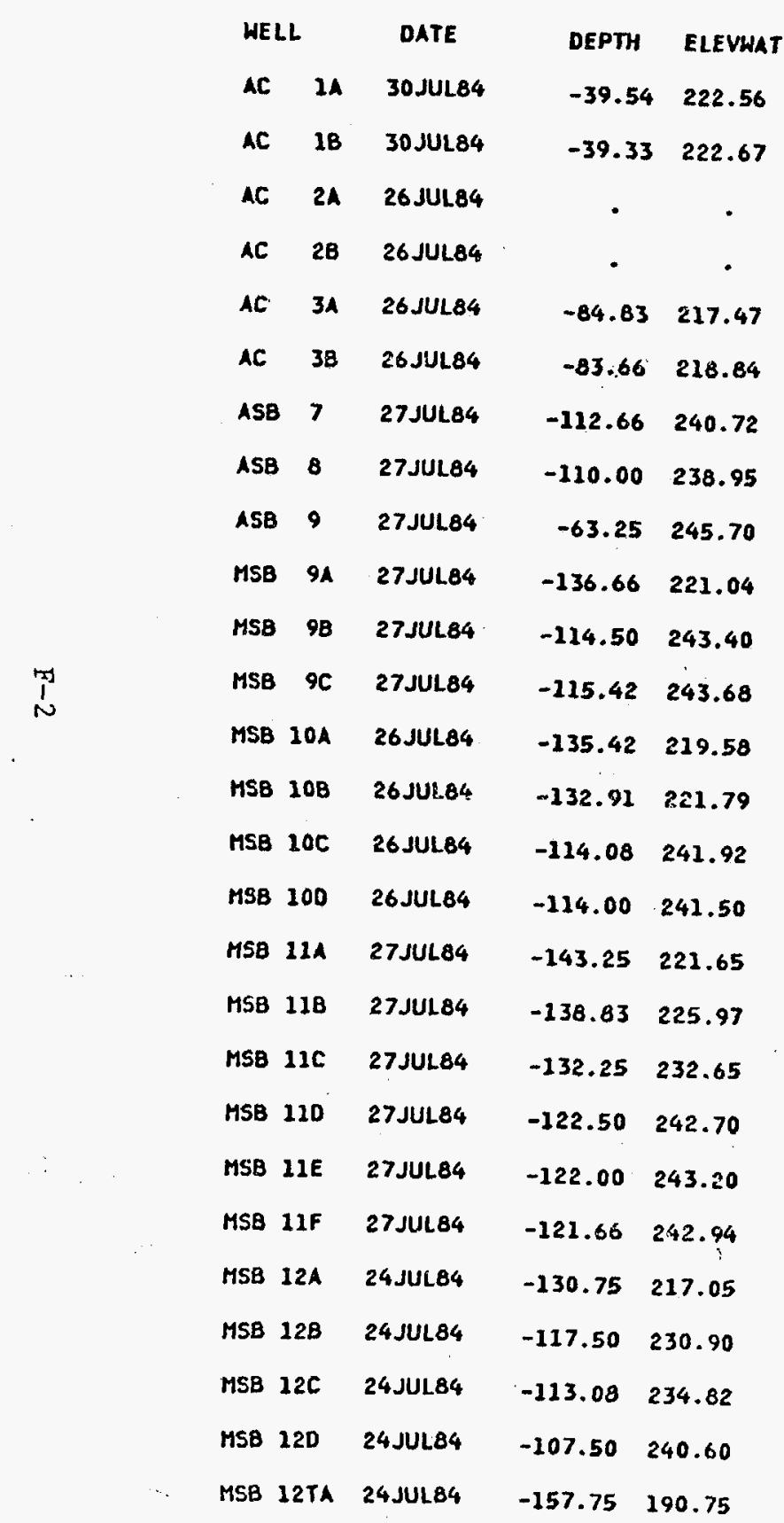

\begin{tabular}{|c|c|c|c|c|}
\hline WELL & & DATE & DEPTH & ELEVWAT \\
\hline MSB & $12 \mathrm{~TB}$ & 24JUL.84 & -158.25 & 190.65 \\
\hline MSB & $13 A$ & 24JUL84 & -129.33 & 215.87 \\
\hline MSB & $13 \mathrm{~B}$ & 24JUL_84 & -114.25 & 231.35 \\
\hline MSB & $13 c$ & 24JUL84 & -103.08 & 242.62 \\
\hline MSB & 144 & 27JUL84 & -121.42 & 226.88 \\
\hline MSB & $14 B$ & $27 J U L 84$ & -219.75 & 228.95 \\
\hline MSB & $14 \mathrm{C}$ & 27JUL84 & -104.00 & 244.70 \\
\hline MSB & $15 \mathrm{~A}$ & 27JUL84 & -134.50 & 232.70 \\
\hline MSB & $15 \mathrm{C}$ & 27JUL84 & -120.33 & 246.27 \\
\hline MSB & 164 & 27JUL84 & -132.46 & 234.24 \\
\hline MSB & $16 \mathrm{C}$ & 27JULB4 & -123.50 & 243.10 \\
\hline MSB & 174 & 24JUL.84 & -133.33 & 224.67 \\
\hline MSB & 178 & 24.JUL84 & -121.83 & 236.07 \\
\hline MSB & $17 C$ & 24JUL84 & -120.00 & 238.10 \\
\hline MSB & $18 \mathrm{~A}$ & 25JUL84 & -121.66 & 218.54 \\
\hline MSB & 288 & 25JUL84 & -110.56 & 229.74 \\
\hline MSB & $18 C$ & 25JUL84 & -103.91 & 236.69 \\
\hline MSB & $19 A$ & 27JUL84 & -81.00 & 218.50 \\
\hline MSa & 198 & $27 J U L 84$ & -77.17 & 222.73 \\
\hline MSB & $19 \mathrm{C}$ & 27JUL84 & -53.58 & 246.62 \\
\hline MSB & $20 \Omega$ & 26 JUL84 & -126.75 & 227.25 \\
\hline MSB & $20 \mathrm{C}$ & 26.JUL84 & -116.00 & 237.30 \\
\hline MSB & $21 \mathrm{~A}$ & 26 JUL84 & -123.75 & 229.65 \\
\hline MSB & $21 \mathrm{C}$ & 26 JUL84 & -113.08 & 240.32 \\
\hline MSB & 22 & 27JUL84 & -115.83 & 246.47 \\
\hline MSB & 23 & 30 JUL84 & -127.04 & 244.73 \\
\hline MSB & 238 & .484 & -135.71 & 35.89 \\
\hline
\end{tabular}

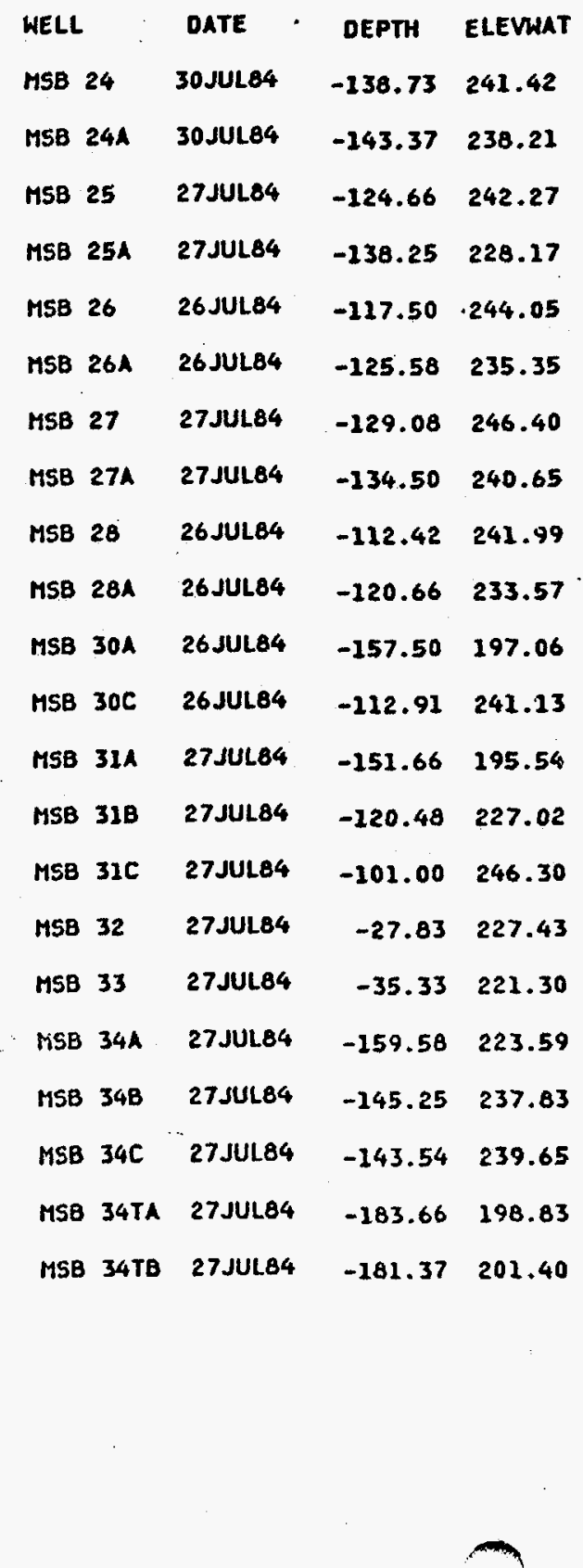


APPENDIX F. WATER-LEVEL ELEVATIONS IN OBSERVATION WELLS IN THE A AND M AREA VICINITY.

WELL SAMPLE DATE WATER ELEVATION

\begin{tabular}{|c|c|c|c|}
\hline ABG & 1 & 061284 & 227.37 \\
\hline AC & $1 \mathrm{~A}$ & 050283 & 217.10 \\
\hline$A C$ & $1 A$ & 071283 & 219.04 \\
\hline $\mathrm{AC}$ & IA & 060784 & 221.63 \\
\hline$A C$ & 1B & 042683 & 217.20 \\
\hline$A C$ & $1 B$ & 071283 & 219.16 \\
\hline$A C$ & 1B & 060784 & 222.69 \\
\hline$A C$ & $2 \mathrm{~A}$ & 042383 & 226.30 \\
\hline$A C$ & $2 A$ & 071183 & 227.25 \\
\hline$A C$ & $2 \mathrm{~A}$ & 050184 & 230.79 \\
\hline$A C$ & $2 A$ & 061384 & 229.52 \\
\hline$A C$ & $2 \mathrm{~A}$ & 091984 & 230.76 \\
\hline$A C$ & $2 B$ & 051083 & 233.50 \\
\hline$A C$ & $2 B$ & 071183 & 235.00 \\
\hline$A C$ & $2 B$ & 050184 & 239.19 \\
\hline$A C$ & $2 \mathrm{~B}$ & 091984 & 237.33 \\
\hline$A C$ & $3 A$ & 042983 & 214.30 \\
\hline$A C$ & $3 A$ & 071283 & 215.11 \\
\hline$A C$ & 3A & 032484 & 219.90 \\
\hline$A C$ & $3 A$ & 060784 & 218.57 \\
\hline$A C$ & $3 B$ & 042983 & 215.20 \\
\hline$A C$ & 38 & 071283 & 215.82 \\
\hline$A C$ & $3 B$ & 032484 & 220.71 \\
\hline$A C$ & $3 B$ & 032484 & 220.71 \\
\hline$A C$ & 38 & 060784 & 219.39 \\
\hline $\mathrm{AOB}$ & 1 & 061184 & 245.82 \\
\hline$A D B$ & 2 & 061184 & 245.55 \\
\hline$A S B$ & 4 & 061284 & 241.71 \\
\hline ASB & 7 & 051484 & 241.93 \\
\hline ASB & 8 & 053084 & 242.45 \\
\hline LA & 4 & 051884 & 207.00 \\
\hline MPT & 1 & 070783 & 236.77 \\
\hline$M P X$ & 1 & 082283 & 223.06 \\
\hline $\mathrm{MPT}$ & 1 & 082683 & 222.04 \\
\hline $\mathrm{MPT}$ & 1 & 092383 & 223.16 \\
\hline MPT & 1 & 092683 & $223 \cdot 16$ \\
\hline MPT & 1 & 092983 & 223 \\
\hline $\mathrm{MPT}$ & 1 & 101483 & 222.84 \\
\hline MPT & 1 & 101883 & 225.66 \\
\hline MPT & 1 & 102083 & 223.16 \\
\hline $\mathrm{MPT}$ & 1 & 102583 & 222.66 \\
\hline MPT & 1 & 103183 & 224.16 \\
\hline MPT & 1 & 113083 & 221.76 \\
\hline MPT & 1 & 120583 & 221.91 \\
\hline MSB & $1 \mathrm{~A}$ & 050384 & 242.33 \\
\hline MSB & $2 \mathrm{~A}$ & 050384 & 242.48 \\
\hline MSB & $3 \mathrm{~A}$ & 032184 & 242.35 \\
\hline $\mathrm{MSB}$ & $3 \mathrm{~A}$ & 032184 & 242.35 \\
\hline $\mathrm{MSB}$ & $3 A$ & 050384 & 242.28 \\
\hline MSB & $4 \mathrm{~A}$ & 050384 & 242.15 \\
\hline $\mathrm{MSB}$ & $5 A$ & 051084 & 230.70 \\
\hline MSB & $5 A$ & 021284 & 240.07 \\
\hline
\end{tabular}

WELL SAMPLE DATE WATER ELEVATION

\begin{tabular}{|c|c|c|c|c|}
\hline MSB & $6 A$ & 051084 & & 224.43 \\
\hline MSB & $7 \mathrm{~A}$ & 051084 & & 225.72 \\
\hline MSB & $7 A$ & 091284 & & 238.48 \\
\hline MSB & $8 A$ & 051084 & & 225.70 \\
\hline MSB & $8 \mathrm{~A}$ & 091284 & & 241.16 \\
\hline $\mathrm{MSB}$ & $9 \mathrm{~A}$ & 042483 & & 218.60 \\
\hline MSB & $9 A$ & 070783 & & 218.90 \\
\hline MSB & $9 A$ & 041384 & & 222.56 \\
\hline MSB & $9 A$ & 090684 & & 221.84 \\
\hline MSB & $9 B$ & 062983 & & 241.69 \\
\hline MSB & $9 B$ & 041784 & & 244.72 \\
\hline $\mathrm{MSB}$ & $9 B$ & 090684 & & 244.38 \\
\hline MSB & $9 C$ & 051683 & & 241.90 \\
\hline MSB & $9 \mathrm{C}$ & 062983 & & 241.87 \\
\hline MSB & $9 \mathrm{C}$ & 041684 & & 244.97 \\
\hline MSB & $9 C$ & 090684 & & 244.55 \\
\hline MSB & $10 \mathrm{~A}$ & 042483 & & 216.50 \\
\hline MSB & $10 \mathrm{~A}$ & 041784 & & 220.96 \\
\hline MSB & $10 \mathrm{~A}$ & 091084 & & 220.90 \\
\hline$M S B$ & $10 B$ & 062783 & & 220.12 \\
\hline$M S B$ & $10 \mathrm{~B}$ & 070783 & & 220.17 \\
\hline MSB & $10 \mathrm{~B}$ & 0.11884 & & 223.32 \\
\hline$M S B$ & 108 & 091084 & & 223.42 \\
\hline MSB & $10 \mathrm{C}$ & 042483 & & 210.20 \\
\hline $\mathrm{MSB}$ & $10 c$ & 070783 & - & 240.09 \\
\hline $\mathrm{MSB}$ & $10 \mathrm{C}$ & 041884 & & 243.00 \\
\hline $\mathrm{MSB}$ & $10 \mathrm{C}$ & 091084 & & 2.12 .86 \\
\hline MSB & $10 D$ & 041884 & & 242.72 \\
\hline MSB & $11 \mathrm{~A}$ & 042483 & & 219.10 \\
\hline $\mathrm{MSB}$ & $11 \mathrm{~A}$ & $\mathrm{C62783}$ & & 219.59 \\
\hline $\mathrm{MSB}$ & $11 \mathrm{~A}$ & 082283 & & 220.30 \\
\hline MSB & 11.4 & $0 \$ 2683$ & & 220.30 \\
\hline MSB & 11. & 091683 & & 220.36 \\
\hline MSB & $11 \mathrm{~A}$ & 092083 & & 220.45 \\
\hline$M S B$ & $11 \mathrm{~A}$ & 092383 & & 220.54 \\
\hline$M S B$ & $11 \mathrm{~A}$ & 092683 & & 220.54 \\
\hline$M S B$ & $11 \mathrm{~A}$ & 092983 & & 220.55 \\
\hline MSB & $11 \mathrm{~A}$ & 120583 & & $221 \cdot 10$ \\
\hline MSB & $11 \mathrm{~A}$ & 032184 & & 221.26 \\
\hline MSB & $11 \mathrm{~A}$ & 041284 & & 223.28 \\
\hline $\mathrm{MSB}$ & $11 \mathrm{~A}$ & 090584 & & 222.38 \\
\hline $\mathrm{MSB}$ & 11B & 062883 & & 231.09 \\
\hline MSB & 11B & 082283 & & 229.94 \\
\hline MSB & $11 \mathrm{~B}$ & 082683 & & 229.87 \\
\hline MSB & 11B & 091683 & & 231.30 \\
\hline MSB & $11 \mathrm{~B}$ & 092083 & & 230.43 \\
\hline$M S B$ & $11 \mathrm{~B}$ & 092383 & & 230.10 \\
\hline $\mathrm{MSB}$ & $11 \mathrm{~B}$ & 092683 & & 230.10 \\
\hline $\mathrm{MSB}$ & $11 B$ & 092983 & & 230.08 \\
\hline $\mathrm{MSB}$ & $11 B$ & 113083 & & 230.00 \\
\hline MSB & $11 B$ & 032184 & & 230.53 \\
\hline MSB & $11 \mathrm{~B}$ & 041284 & & 232.22 \\
\hline MSB & $11 \mathrm{~B}$ & 090584 & & 231.62 \\
\hline
\end{tabular}


APPENDIX F. WATER-LEVEL ELEVATIONS IN OBSERVATION WELLS IN THE A AND M

AREA VICINITY.

WELL SAMPLE DATE WATER ELEVATION

\begin{tabular}{|c|c|c|c|c|}
\hline MSB & $11 \mathrm{C}$ & 062883 & & 232.32 \\
\hline MSB & $11 C$ & 082283 & & 231.95 \\
\hline MSB & $11 \mathrm{C}$ & 082683 & & 231.80 \\
\hline MSB & $11 C$ & 091683 & & 233.82 \\
\hline MSB & $11 \mathrm{C}$ & 092083 & & 232.59 \\
\hline MSB & $11 C$ & 092383 & & 232.22 \\
\hline MSB & $11 \mathrm{C}$ & 092683 & & 232.22 \\
\hline MSB & $11 \mathrm{C}$ & 092983 & & 232.23 \\
\hline MSB & $11 \mathrm{C}$ & 112883 & & 232.40 \\
\hline MSB & $11 \mathrm{C}$ & 041284 & & 233.72 \\
\hline MSB & $11 \mathrm{C}$ & 090584 & & 233.77 \\
\hline MSB & 11D & 062783 & & 241.97 \\
\hline MSB & 110 & 082283 & & 241.95 \\
\hline MSB & 11D & 082683 & & 242.02 \\
\hline MSB & 11D & 091683 & & 242.49 \\
\hline MSB & 110 & 092083 & & 242.46 \\
\hline MSB & 11D & 092383 & & 241.96 \\
\hline MSB & 11D & 0.92683 & & 241.96 \\
\hline MSB & 11D & 092983 & & 242.25 \\
\hline MSB & 11D & 112883 & & 242.44 \\
\hline MSB & 11D & 041284 & & 243.90 \\
\hline MSB & 11D & 090684 & & 243.69 \\
\hline MSB & $11 \mathrm{E}$ & 082283 & & 242.71 \\
\hline MSB & $11 \mathrm{E}$ & 082683 & & 242.63 \\
\hline MSB & $11 F$ & 070783 & & 241.88 \\
\hline MSB & $11 \bar{F}$ & 082283 & & 242.32 \\
\hline$M S B$ & $11 F$ & $0 \$ 2683$ & & 242.39 \\
\hline MSB & $11 \mathrm{~F}$ & 091683 & & 242.58 \\
\hline$M S B$ & $11 F$ & 092083 & & 242.70 \\
\hline MSB & $11 \mathrm{~F}$ & 092383 & & 242.68 \\
\hline MSB & $11 \mathrm{~F}$ & 092683 & & 242.68 \\
\hline MSB & $11 F$ & 092983 & & 242.68 \\
\hline MSB & $11 F$ & 120583 & & 241.98 \\
\hline$M S B$ & $11 F$ & 032184 & & 242.89 \\
\hline MSB & 115 & 032134 & - & 242.8 \\
\hline MSB & $11 \mathrm{~F}$ & 041284 & 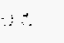 & 244.20 \\
\hline MSB & $11 \mathrm{~F}$ & 090684 & $\because$ & 244.10 \\
\hline MSB. & $12 \mathrm{~A}$ & 062783 & $\therefore$ & 214.83 \\
\hline MSB & $12 \mathrm{~A}$ & 032284 & & 216.75 \\
\hline NSB B & $12 \mathrm{~A}$ & 041984 & & 218.37 \\
\hline MSB & $12 \mathrm{~A}$ & 091184 & & 218.40 \\
\hline MSB & $12 \mathrm{~B}$ & 042783 & & 224.60 \\
\hline MSB & $12 B$ & 070783 & & 221.17 \\
\hline MSB & $12 B$ & 032284 & & 229.60 \\
\hline MSB & $12 B$ & 041984 & & 229.85 \\
\hline ISB & $12 B$ & 091184 & & 229.76 \\
\hline MSB & $12 C$ & 042783 & & 232.90 \\
\hline MSB & $12 C$ & 032284 & & 234.35 \\
\hline MSB & $12 C$ & 041884 & & 233.25 \\
\hline MSB & $12 C$ & 091184 & & 233.23 \\
\hline MSB & 12D & 070783 & & 239.03 \\
\hline ISB & $12 \mathrm{D}$ & 032284 & & 239.20 \\
\hline MSB & 120 & 041884 & & 242.70 \\
\hline
\end{tabular}

WELL SAMPLE DATE WATER ELEVATION

\begin{tabular}{|c|c|c|c|c|}
\hline MSB & $12 \mathrm{D}$ & 091184 & & 242.66 \\
\hline MSB & $12 \mathrm{TA}$ & 102483 & & 189.50 \\
\hline MSB & $12 \mathrm{TA}$ & 102583 & & 190.50 \\
\hline MSB & $12 \mathrm{TA}$ & 102683 & & 189.50 \\
\hline MSB & $12 \mathrm{TA}$ & 051784 & & 193.55 \\
\hline MSB & $12 \mathrm{TA}$ & 052284 & & 193.60 \\
\hline MSB & $12 \mathrm{TA}$ & 052584 & & 193.16 \\
\hline MSB & $12 \mathrm{TA}$ & 091084 & & 194.20 \\
\hline MSB & $12 \mathrm{~TB}$ & 102483 & & 190.90 \\
\hline MSB & $12 \mathrm{~TB}$ & 102583 & & 190.90 \\
\hline MSB & $12 \mathrm{~TB}$ & 102683 & & 190.90 \\
\hline MSB & $12 \mathrm{~TB}$ & 051784 & & 193.99 \\
\hline MSB & $12 \mathrm{~TB}$ & 052184 & & 194.05 \\
\hline SB & $12 \mathrm{~TB}$ & 052384 & & 193.90 \\
\hline MSB & $12 \mathrm{~TB}$ & 091084 & & 196.78 \\
\hline MSB & $13 \mathrm{~A}$ & 042883 & & 213.50 \\
\hline MSB & $13 \mathrm{~A}$ & 071283 & & 214.42 \\
\hline MSB & $13 \mathrm{~A}$ & 042084 & & 217.15 \\
\hline MSB & $13 \mathrm{~A}$ & 091184 & & 217.15 \\
\hline MSB & $13 \mathrm{~B}$ & 070583 & & 229.29 \\
\hline MSB & 133 & 042084 & & 232.20 \\
\hline MSB & $13 \mathrm{~B}$ & 091284 & & 232.16 \\
\hline MSB & $13 C$ & 042883 & & 241.60 \\
\hline MSB & $13 C$ & 071283 & & 241.20 \\
\hline MSB & $13 \mathrm{C}$ & 0.12094 & & 244.11 \\
\hline MSB & $13 \mathrm{C}$ & 091284 & & 244.46 \\
\hline MSB & $14 \mathrm{~A}$ & 0.12783 & & 225.10 \\
\hline SB & $11 \mathrm{~A}$ & 071183 & & 226.10 \\
\hline B & $14 \mathrm{~A}$ & 041384 & & 228.35 \\
\hline 3 & $14 \mathrm{~A}$ & 061484 & & 228.01 \\
\hline 58 & $14 \mathrm{~A}$ & 090434 & & 227.69 \\
\hline MSB & $1+3$ & 062983 & & 227.39 \\
\hline SB & 143 & 041384 & & 230.34 \\
\hline MSB & $14 B$ & 090484 & . & 229.65 \\
\hline MSB & $14 \mathrm{C}$ & 042783 & $\because$ & 244.20 \\
\hline MSB & $14 \mathrm{C}$ & 071183 & & 243.24 \\
\hline MSB & $14 \mathrm{C}$ & 041384 & & 245.72 \\
\hline SB & $14 \mathrm{C}$ & 090584 & & 245.26 \\
\hline SB & $15 \mathrm{~A}$ & 042883 & & 231.10 \\
\hline MSB & $15 A$ & 062783 & & 231.19 \\
\hline MSB & $15 \mathrm{~A}$ & 041684 & $:$ & 234.22 \\
\hline MSB & $15 \mathrm{~A}$ & 090784 & & 233.41 \\
\hline MSB & $16 \mathrm{~A}$ & 042383 & & 232.70 \\
\hline MSB & $16 \mathrm{~A}$ & 062783 & & 232.85 \\
\hline SB & $16 \mathrm{~A}$ & 041784 & & 235.58 \\
\hline SB & $16 \mathrm{~A}$ & 090784 & & 235.21 \\
\hline MSB & $16 \mathrm{C}$ & 042483 & & 241.10 \\
\hline MSB & $16 \mathrm{C}$ & 062883 & & 241.48 \\
\hline MSB & $16 \mathrm{C}$ & 041784 & & 243.80 \\
\hline MSB & $16 \mathrm{C}$ & 090784 & & 243.96 \\
\hline MSB & $17 \mathrm{~A}$ & 042883 & & 222.20 \\
\hline $\mathbf{S}$ & $17 \mathrm{~A}$ & 071183 & & 224.18 \\
\hline & $17 \mathrm{~A}$ & 042384 & & 226.60 \\
\hline
\end{tabular}


APPENDIX F. WATER-LEVEL ELEVATIONS IN OBSERVATION HELLS IN THE A AND M

AREA VICINITY.

WELL SAMPLE DATE WATER ELEVATION

\begin{tabular}{|c|c|c|c|c|}
\hline MSB & $17 \mathrm{~A}$ & 091384 & & 226.56 \\
\hline MSB & 178 & 042983 & & 234.10 \\
\hline MSB & $17 \mathrm{~B}$ & 071183 & & 235.42 \\
\hline MSB & $17 \mathrm{~B}$ & 042484 & & 238.78 \\
\hline MSB & $17 B$ & 091384 & & 238.70 \\
\hline MSB & $18 \mathrm{~A}$ & 062883 & & 216.55 \\
\hline MSB & $18 \mathrm{~A}$ & 070183 & & 217.62 \\
\hline MSB & $18 \mathrm{~A}$ & 042384 & & 220.35 \\
\hline MSB & $18 \mathrm{~A}$ & 091384 & & 220.07 \\
\hline MSB & $18 \mathrm{~B}$ & 042883 & & 226.80 \\
\hline MSB & $18 \mathrm{~B}$ & 071283 & & 227.13 \\
\hline MSB & $18 \mathrm{~B}$ & 042384 & & 230.95 \\
\hline MSB & $18 \mathrm{~B}$ & 091384 & & 230.85 \\
\hline MSB & $18 \mathrm{C}$ & 042883 & & 232.90 \\
\hline MSB & $18 \mathrm{C}$ & 071283 & & 234.10 \\
\hline MSB & $18 \mathrm{C}$ & 042384 & & 236.00 \\
\hline MSB & $18 \mathrm{C}$ & 091384 & & 235.85 \\
\hline MSB & $19 \mathrm{~A}$ & 043083 & & 217.00 \\
\hline MSB & $19 \mathrm{~A}$ & 060884 & & 219.17 \\
\hline MSB & $19 B$ & 060884 & & 222.39 \\
\hline $\mathrm{MSB}$ & $19 \mathrm{C}$ & 043083 & & 243.80 \\
\hline MSB & $19 \mathrm{C}$ & 071183 & & 244.55 \\
\hline MSB & $19 \mathrm{C}$ & 061384 & & 245.82 \\
\hline MSB & $20 \mathrm{~A}$ & 042383 & & 224.00 \\
\hline MSB & $20 \mathrm{~A}$ & 070683 & & 224.86 \\
\hline MSB & $20 \mathrm{~A}$ & 042481 & & 228.45 \\
\hline MSB & $20 \mathrm{~A}$ & 091784 & & 228.40 \\
\hline YSB & $20 \mathrm{C}$ & 042383 & & 234.00 \\
\hline MSB & $20 c$ & 070683 & & 234.68 \\
\hline MSB & $20 c$ & 042484 & & 238.30 \\
\hline MSB & $20 \mathrm{C}$ & 091784 & & 238.19 \\
\hline MSB & $21 \mathrm{~A}$ & 042383 & & 226.80 \\
\hline MSB & $21 \mathrm{~A}$ & 071183 & & 227.60 \\
\hline$M S B$ & $21 \mathrm{~A}$ & 042584 & & 230.85 \\
\hline MSB & $21 \mathrm{~A}$ & 091784 & & 230.75 \\
\hline MSB & $21 \mathrm{C}$ & 042383 & & 237.10 \\
\hline MSB & $21 \mathrm{C}$ & 042484 & & 240.95 \\
\hline MSB & $21 C$ & 091784 & & 240.90 \\
\hline MSB & 22 & 062783 & & 241.32 \\
\hline MSB & 22 & 032184 . & & 240.12 \\
\hline MSB & 22 & 032184 & & 240.12 \\
\hline MSB & 22 & 041384 & & 244.23 \\
\hline MSB & 22 & 090584 & & 243.97 \\
\hline MSB & 23 & 050983 & $\because$ & 243.57 \\
\hline MSB & 23 & 070683 & & 243.77 \\
\hline MSB & 23 & 051184 & & 245.37 \\
\hline MSB & $23 \mathrm{~A}$ & 050983 & & 198.62 \\
\hline MSB & $23 A$ & 070683 & & 198.36 \\
\hline$M S B$ & $23 \mathrm{~A}$ & 051184 & & 202.60 \\
\hline $\mathrm{MSB}$ & $23 \mathrm{~A}$ & 052484 & 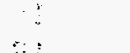 & 199.44 \\
\hline MSB & $23 A$ & 052984 & & 201.70 \\
\hline MSB & $23 A$ & 060584 & $\because:$ & 202.05 \\
\hline MSB & $23 A$ & 071084 & & 202.03 \\
\hline
\end{tabular}

WELL SAMPLE DATE WATER ELEVATIO!

\begin{tabular}{|c|c|c|c|c|}
\hline MSB & $23 \mathrm{~A}$ & 082484 & & 200.01 \\
\hline MSB & $23 \mathrm{~A}$ & 082884 & & 199.93 \\
\hline MSB & $23 B$ & 050983 & & 234.30 \\
\hline MSB & $23 B$ & 070683 & & 234.62 \\
\hline MSB & $23 B$ & 051184 & & 237.08 \\
\hline MSB & 24 & 042983 & & 238.45 \\
\hline MSB & 24 & 070783 & & 240.01 \\
\hline MSB & 24 & 032384 & & 239.32 \\
\hline MSB & 24 & 051584 & & 240.30 \\
\hline MSB & $24 \mathrm{~A}$ & 042983 & & 237.08 \\
\hline MSB & $24 \mathrm{~A}$ & 070783 & & 237.29 \\
\hline MSB & $24 \mathrm{~A}$ & 032384 & & 231.90 \\
\hline MSB & $24 A$ & 032384 & & 231.90 \\
\hline MSB & $24 \mathrm{~A}$ & 051584 & & 237.06 \\
\hline MSB & 25 & 051683 & & 240.53 \\
\hline MSB & 25 & 071283 & & 242.32 \\
\hline MSB & 25 & 051584 & & 241.15 \\
\hline MSB & $25 \mathrm{~A}$ & 051683 & & 226.32 \\
\hline MSB & $25 A$ & 071283 & & 228.31 \\
\hline MSB & $25 \mathrm{~A}$ & 051584 & 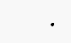 & 227.36 \\
\hline MSB & 26 & 051083 & & 242.45 \\
\hline MSB & 26 & 071183 & & 243.01 \\
\hline MSB & 26 & 042684 & & 242.42 \\
\hline MSB & 26 & 091784 & & 242.38 \\
\hline MSB & $26 A$ & 051083 & & 233.23 \\
\hline MSB & $26 A$ & 071183 & & 233.97 \\
\hline MSB & $26 A$ & 042684 & & 236.35 \\
\hline MSB & $26 \mathrm{~A}$ & 091884 & & 236.39 \\
\hline MSB & 27 & 051683 & & 244.18 \\
\hline MSB & 27 & 071183 & & 242.93 \\
\hline $\mathrm{MSB}$ & 27 & 032484 & & 249.64 \\
\hline MSB & 27 & 042684 & & 246.45 \\
\hline MSB & 27 & 091984 & & 246.37 \\
\hline MSB & $27 \mathrm{~A}$ & 051083 & & 239.15 \\
\hline MSB & $27 \mathrm{~A}$ & 071183 & & 242.60 \\
\hline MSB & 27A & 042684 & & 241.80 \\
\hline MSB & $27 \mathrm{~A}$ & 061384 & & 240.23 \\
\hline MSB & $27 \mathrm{~A}$ & 092084 & & 240.21 \\
\hline MSB & 28 & 051283 & & 239.21 \\
\hline MSB & 28 & 071183 & & 239.96 \\
\hline MSB & 28 & 032584 & & 253.48 \\
\hline MSB & 28 & 043084 & & 241.69 \\
\hline MSB & 28 & 091884 & & 241.67 \\
\hline MSB & $28 \mathrm{~A}$ & 051283 & & 231.03 \\
\hline MSB & $28 \mathrm{~A}$ & 043084 & & 234.78 \\
\hline MSB & $28 \mathrm{~A}$ & 091884 & & 234.76 \\
\hline MSB & $30 A$ & 051283 & & 194.56 \\
\hline MSB & $30 A$ & 070583 & & 196.91 \\
\hline MSB & $30 A$ & 032484 & & 201.15 \\
\hline MSB & $30 \mathrm{~A}$ & 043084 & & 200.56 \\
\hline MSB & $30 \mathrm{~A}$ & 052184 & & 198.20 \\
\hline MSI & $30 \mathrm{~A}:$ & 083184 & $\cdots$ & 198.96 \\
\hline MSB & $30 \mathrm{C}$ & 051283 & $\because z$ & 237.74 \\
\hline
\end{tabular}


APPENDIX F. WATER-LEVEL ELEVATIONS IN OBSERVATION WELLS IN THE A AND $M$

AREA VICINITY.

WELL SAMPLE DATE WATER ELEVATION

\begin{tabular}{|c|c|c|c|}
\hline MSB & $30 \mathrm{C}$ & 070583 & 238.44 \\
\hline MSB & $30 \mathrm{C}$ & 043084 & 241.54 \\
\hline MSB & $30 \mathrm{C}$ & 091984 & 242.51 \\
\hline MSB & $31 \mathrm{~A}$ & 100583 & 194.24 \\
\hline MSB & $31 \mathrm{~A}$ & 101083 & 194.40 \\
\hline MSB & $31 \mathrm{~A}$ & 050984 & 198.91 \\
\hline MSB & $31 \mathrm{~A}$ & 052284 & 199.59 \\
\hline MSB & $31 \mathrm{~A}$ & 052584 & 195.60 \\
\hline MSB & $31 \mathrm{~B}$ & 062983 & 225.74 \\
\hline MSB & $31 \mathrm{~B}$ & 050984 & 229.06 \\
\hline MSB & $31 \mathrm{C}$ & 062883 & 244.59 \\
\hline MSB & $31 \mathrm{C}$ & 050984 & 247.40 \\
\hline MSB & 32 & 062883 & 225.76 \\
\hline MSB & 32 & 061484 & 228.62 \\
\hline MSB & 33 & 050283 & 220.33 \\
\hline MSB & 33 & 062883 & 220.28 \\
\hline MSB & 33 & 050984 & 223.63 \\
\hline MSB & $34 \mathrm{~A}$ & 090883 & 215.50 \\
\hline MSB & $3 \$ A$ & 042584 & 225.47 \\
\hline MSB & $34 A$ & 072684 & 223.33 \\
\hline MSB & $34 \mathrm{~B}$ & 090883 & 237.18 \\
\hline MSB & $34 \mathrm{~B}$ & 042534 & 239.35 \\
\hline MSB & $34 B$ & 072684 & 233.18 \\
\hline MSB & $3.1 B$ & 080684 & 238.10 \\
\hline MS & $3 A B$ & 082184 & 238.50 \\
\hline MSB & $31 c$ & 090853 & 238.99 \\
\hline$M S 3$ & $34 c$ & 042584 & 241.04 \\
\hline MSB & $3 A C$ & 072684 & 240.05 \\
\hline MSB & $34 \mathrm{TA}$ & 091283 & 197.49 \\
\hline$M S B$ & $3 A T A$ & 091583 & 197.47 \\
\hline MSB & $34 \mathrm{TA}$ & 091983 & 197.74 \\
\hline MSB & $34 \mathrm{TA}$ & 102683 & 197.99 \\
\hline MSB & $34 T A$ & 051684 & 199.22 \\
\hline$M S B$ & $34 \mathrm{TA}$ & 051884 & 199.49 \\
\hline MSB & $34 \mathrm{TA}$ & 071984 & 195.89 \\
\hline MSB & 34TA & 071954 & 195.89 \\
\hline MSB & $34 T A$ & 082184 & 201.04 \\
\hline MSB & $34 \mathrm{~TB}$ & 090883 & 199.27 \\
\hline MSB & $34 \mathrm{~TB}$ & 051684 & 204.18 \\
\hline MSB & $34 \mathrm{~TB}$ & 051884 & 204.26 \\
\hline MSB & $34 \mathrm{~TB}$ & 071884 & 201.46 \\
\hline MSB & $34 T B$ & 071884 & 201.46 \\
\hline MSB & $34 \mathrm{~TB}$ & 082184 & 203.73 \\
\hline RHM & 2 & 011284 & 209.26 \\
\hline RHM & 2 & 011484 & 208.88 \\
\hline Rim & 2 & 011584 & 228.81 \\
\hline$R W M$ & 2 & 012584 & 210.69 \\
\hline RHM & 2 & 012684 & 211.28 \\
\hline$R H M$ & 2 & 012784 & 212.28 \\
\hline RHM & 2 & 012884 & 212.83 \\
\hline RWM & 2 & 012984 & 213.03 \\
\hline RWM & 2 & 013084 & 212.57 \\
\hline RWH & 2 & 013184 & 21208 \\
\hline
\end{tabular}

WELL SAMPLE DATE WATER ELEVATION

\begin{tabular}{|c|c|c|}
\hline RWM & 2 & 020184 \\
\hline RHA & 2 & 020284 \\
\hline RHM & 2 & 020384 \\
\hline RUM & 2 & 020481 \\
\hline RUM & 2 & 021584 \\
\hline RUM & 2 & 021784 \\
\hline RUM & 2 & 022484 \\
\hline RHM & 2 & 022884 \\
\hline $\mathrm{R} w \mathrm{M}$ & 2 & 030284 \\
\hline RWM & 2 & 030984 \\
\hline RHM & 2 & 031384 \\
\hline $\mathrm{R} W \mathrm{M}$ & 2 & 032084 \\
\hline RHM & 2 & 032384 \\
\hline RWM & 2 & 032384 \\
\hline RWM & 2 & 033084 \\
\hline $\mathrm{RHM}$ & 3 & 020284 \\
\hline $\mathrm{RH} M$ & 3 & 020384 \\
\hline RHM & 3 & 020484 \\
\hline RHM & 3 & 020584 \\
\hline $\mathrm{RWM}$ & 3 & 020684 \\
\hline$R H M$ & 3 & 020784 \\
\hline $\mathrm{KPM}$ & 3 & 020884 \\
\hline $\mathrm{R}: \mathrm{M}$ & 3 & 020984 \\
\hline$R^{*}: 31$ & 3 & 021084 \\
\hline$R H M$ & 3 & 021184 \\
\hline $\mathrm{R} ! \mathrm{M}$ & 3 & 021284 \\
\hline $\mathrm{R} M \mathrm{M}$ & 3 & 021394 \\
\hline RMM & 3 & 021584 \\
\hline RHII & 3 & 021784 \\
\hline $\mathrm{R} 4 \mathrm{M}$ & 3 & 022184 \\
\hline $\mathrm{RHM}$ & 3 & 022484 \\
\hline RHM & 3 & 022881 \\
\hline RHM & 3 & 030284 \\
\hline RWM & 3 & 030984 \\
\hline RHM & 3 & 031384 \\
\hline RWM & 3 & 032084 \\
\hline RHM & 3 & 032384 \\
\hline RHM & 3 & 032384 \\
\hline RUM & 3 & 033084 \\
\hline SRH & $1 \mathrm{C}$ & 050484 \\
\hline SRH & $1 \mathrm{C}$ & 092684 \\
\hline SRW & $2 \mathrm{~A}$ & 050284 \\
\hline SRW & $2 \mathrm{~A}$ & 072584 \\
\hline SRW & $2 A$ & 092084 \\
\hline SRW & 2B & 050284 \\
\hline SRW & $2 B$ & 092084 \\
\hline SRW & $2 C$ & 092684 \\
\hline SRW & $3 C$ & 050284 \\
\hline SRW & $4 C$ & 050484 \\
\hline SRH & $4 C$ & 092784 \\
\hline SRW & $5 \mathrm{C}$ & 050484 \\
\hline SRW & $5 C$ & 092784 \\
\hline & $9 \mathrm{~A}$ & \\
\hline
\end{tabular}

213.03

213.40

213.62

214.89

201.68

205.74

208.08

207.78

207.48

222.18

222.78

210.68

212.24

212.24

207.48

231.37

231.81

232.25

226.93

226.89

226.45

226.33

225.35

226.48

226.017

226.75

226.92

231.97

230.07

230.30

231.43

231.43

230.13

230.23

230.63

228.43

228.19

228.19

228.83

219.98

220.08

212.09

214.38

212.17

213.13

213.14

229.85

219.15

220.9 ?

220.85

217.57

217.53

206.41 
APPENDIX F. WATER-LEVEL ELEVATIONS IN OBSERVATION WELLS IN THE A AND $M$ AREA VICINITY.

WELL SAMPLE DATE WATER ELEVATION

\begin{tabular}{|c|c|c|c|c|}
\hline SRW & $9 \mathrm{~B}$ & 060484 & & 208.61 \\
\hline SRW & $12 \mathrm{~A}$ & 060484 & & 202.27 \\
\hline SRW & $12 \mathrm{~B}$ & 060484 & & 198.02 \\
\hline SRW & $12 \mathrm{C}$ & 060684 & & 206.02 \\
\hline SRW & $13 \mathrm{~A}$ & 053184 & & 207.74 \\
\hline SRW & 13B & 053184 & & 209.84 \\
\hline SRH & $13 C$ & 060184 & & 214.78 \\
\hline SRH & $14 \mathrm{~A}$ & 050784 & & 211.56 \\
\hline SRW & 14B & 050484 & & 213.10 \\
\hline SRW & $14 \mathrm{C}$ & 050484 & & 219.82 \\
\hline SRW & $15 \mathrm{~A}$ & 050784 & $\therefore$ & 217.46 \\
\hline SRW & $15 B$ & 050784 & & 217.23 \\
\hline SRW & $15 \mathrm{C}$ & 050184 & & 217.76 \\
\hline SRW & $16 \mathrm{~A}$ & 050884 & & 222.85 \\
\hline RW & $16 \mathrm{~B}$ & 050784 & & 222.77 \\
\hline
\end{tabular}

